Campbell Systematic Reviews

2011:6

First published: 29 August, 2011

Last updated: $\quad$ 27 March, 2011

\title{
Motivational interviewing for substance abuse
}

Geir Smedslund, Rigmor C. Berg, Karianne T.

Hammerstrøm, Asbjørn Steiro, Kari A. Leiknes, Helene M. Dahl, Kjetil Karlsen

Please note: Pending reformatting. 


\section{Colophon}

Title Motivational interviewing for substance abuse

Institution The Campbell Collaboration

Authors Geir Smedslund

Rigmor C. Berg

Karianne T. Hammerstrøm

Asbjørn Steiro

Kari A. Leiknes

Helene M. Dahl

Kjetil Karlsen

DOI $10.4073 / \operatorname{csr} .2011 .6$

No. of pages 128

Last updated 27 March, 2011

Citation Smedslund G, Berg RC, Hammerstrøm KT, Steiro A, Leiknes KA, Dahl HM, Karlsen K. Motivational interviewing for substance abuse.

Campbell Systematic Reviews 2011:6

DOI: $10.4073 /$ csr.2011.6

Co-registration This review is co-registered within both the Cochrane and Campbell Collaborations. A version of this review can also be found in the Cochrane Library.

Keywords

Contributions Karlsen conceived of the idea and commissioned the review. All reviewers were involved in planning the review. Smedslund wrote the methods section of the protocol. Karlsen and Smedslund wrote the background. Hammerstrøm developed the search strategy, performed the original searches and the final search in November 2010. All authors were involved with screening of studies. Smedslund and Berg did the risk of bias and data extraction. Berg and Smedslund graded the results. Smedslund did the analyses and wrote the results and discussion.

Support/Funding Norwegian Knowledge Centre for the Health Services, Norway

Potential Conflicts None. of Interest

Corresponding Geir Smedslund

author Norwegian Knowledge Centre for Health Services

PB 7004 St. Olavs plass

Oslo N-0130

Norway

Telephone: +472325 5155/ +479138 7076

E-mail: ges@nokc.no or Geir.Smedslund@kunnskapssenteret.no 


\section{Campbell Systematic Reviews}

Editors-in-Chief Mark W. Lipsey, Vanderbilt University, USA

Arild Bjørndal, The Centre for Child and Adolescent Mental Health, Eastern and Southern Norway \& University of Oslo, Norway

Editors

Crime and J ustice David B. Wilson, George Mason University, USA

Education Sandra Wilson, Vanderbilt University, USA

Social Welfare William Turner, University of Bristol, UK

Geraldine Macdonald, Queen's University, UK \& Cochrane Developmental,

Psychosocial and Learning Problems Group

Managing Editor Karianne Thune Hammerstrøm, The Campbell Collaboration

\section{Editorial Board}

Crime and J ustice David B. Wilson, George Mason University, USA

Martin Killias, University of Zurich, Switzerland

Education Paul Connolly, Queen's University, UK

Gary W. Ritter, University of Arkansas, USA

Social Welfare Aron Shlonsky, University of Toronto, Canada

Paul Montgomery, University of Oxford, UK

Methods Therese Pigott, Loyola University, USA

Peter Tugwell, University of Ottawa, Canada

The Campbell Collaboration (C2) was founded on the principle that systematic reviews on the effects of interventions will inform and help improve policy and services. C2 offers editorial and methodological support to review authors throughout the process of producing a systematic review. A number of C2's editors, librarians, methodologists and external peerreviewers contribute.

The Campbell Collaboration

P.O. Box 7004 St. Olavs plass

0130 Oslo, Norway

www.campbellcollaboration.org 


\section{Motivational interviewing for substance abuse (Review)}

Smedslund G, Berg RC, Hammerstrøm KT, Steiro A, Leiknes KA, Dahl HM, Karlsen K

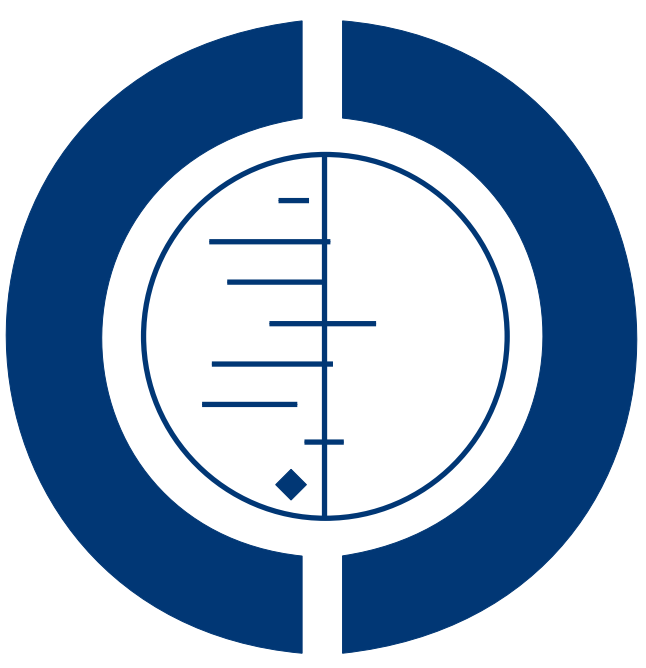

\section{THE COCHRANE COLLABORATION $^{\circledR}$}

This is a reprint of a Cochrane review, prepared and maintained by The Cochrane Collaboration and published in The Cochrane Library 2011, Issue 5

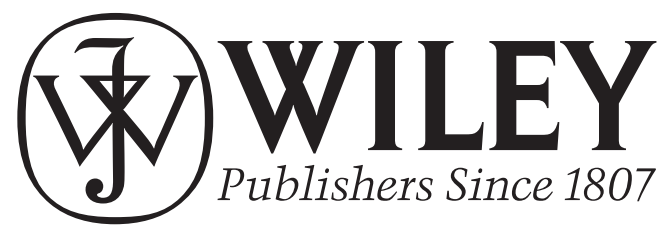

Motivational interviewing for substance abuse (Review)

Copyright (C) 20II The Cochrane Collaboration. Published by John Wiley \& Sons, Ltd. 
TABLE OF CONTENTS

HEADER . . . . . . . . . . . . . . . . . . . . . . . . . . . . . . . . . . . . . . . 1

ABSTRACT . . . . . . . . . . . . . . . . . . . . . . . . . . . . . . . . . . . . . . . . . 1

PLAIN LANGUAGE SUMMARY . . . . . . . . . . . . . . . . . . . . . . . . . . . . . . . . . $\quad 2$

SUMMARY OF FINDINGS FOR THE MAIN COMPARISON . . . . . . . . . . . . . . . . . . . . . 2

BACKGROUND . . . . . . . . . . . . . . . . . . . . . . . . . . . . . . . . . . . . . 6

OBJECTIVES . . . . . . . . . . . . . . . . . . . . . . . . . . . . . . . . . . . . . 47

METHODS . . . . . . . . . . . . . . . . . . . . . . . . . . . . . . . . . . . . . . 7

RESULTS . . . . . . . . . . . . . . . . . . . . . . . . . . . . . . 10

Figure 1. . . . . . . . . . . . . . . . . . . . . . . . . . . . . . 11

Figure 2. . . . . . . . . . . . . . . . . . . . . . . . . . . . . . . . . . . . . . 12

Figure 3. . . . . . . . . . . . . . . . . . . . . . . . . . . . . . . . . . . . . . 14

Figure 4. . . . . . . . . . . . . . . . . . . . . . . . . . . . . 15

Figure 5. . . . . . . . . . . . . . . . . . . . . . . . . . . . . . . 16

Figure 6. . . . . . . . . . . . . . . . . . . . . . . . . . . . . . . . . . . . . . 17

ADDITIONAL SUMMARY OF FINDINGS . . . . . . . . . . . . . . . . . . . . . . . . . . 19

DISCUSSION . . . . . . . . . . . . . . . . . . . . . . . . . . . . . . . . . . . . . 27

AUTHORS' CONCLUSIONS . . . . . . . . . . . . . . . . . . . . . . . . . . . . . . . 28

ACKNOWLEDGEMENTS . . . . . . . . . . . . . . . . . . . . . . . . . . . . . . . . . . . . . . . . . . .

REFERENCES . . . . . . . . . . . . . . . . . . . . . . . . . . . . . . . . . . . . 28

CHARACTERISTICS OF STUDIES . . . . . . . . . . . . . . . . . . . . . . . . . . . . . 40

DATA AND ANALYSES . . . . . . . . . . . . . . . . . . . . . . . . . . . . . . . . . . 109

Analysis 1.1. Comparison $1 \mathrm{MI}$ versus no intervention, Outcome 1 Extent of substance use. . . . . . . . . . . $\quad 110$

Analysis 1.2. Comparison $1 \mathrm{MI}$ versus no intervention, Outcome 2 Readiness to change. . . . . . . . . . . . . 112

Analysis 1.3. Comparison $1 \mathrm{MI}$ versus no intervention, Outcome 3 Retention in treatment. . . . . . . . . . 112

Analysis 2.1. Comparison 2 MI versus treatment as usual, Outcome 1 Extent of substance use. . . . . . . . . . . 113

Analysis 2.2. Comparison 2 MI versus treatment as usual, Outcome 2 Retention in treatment. . . . . . . . . . 114

Analysis 3.1. Comparison 3 MI versus assessment and feedback, Outcome 1 Extent of substance use. . . . . . . $\quad 115$

Analysis 4.1. Comparison 4 MI versus other active intervention, Outcome 1 Extent of substance use. . . . . . . 116

Analysis 4.2. Comparison $4 \mathrm{MI}$ versus other active intervention, Outcome 2 Readiness to change. . . . . . . . . . 117

Analysis 4.3. Comparison 4 MI versus other active intervention, Outcome 3 Retention in treatment. . . . . . . 118

APPENDICES . . . . . . . . . . . . . . . . . . . . . . . . 118

HISTORY . . . . . . . . . . . . . . . . . . . . . . . . . . . . . . . 125

CONTRIBUTIONS OF AUTHORS . . . . . . . . . . . . . . . . . . . . . . . . . . . . . . . . . . . 125

DECLARATIONS OF INTEREST . . . . . . . . . . . . . . . . . . . . . . . . . . . . . . . . . . . . . . . . 125

SOURCES OF SUPPORT . . . . . . . . . . . . . . . . . . . . . . . . . . . . . . . . . 126

DIFFERENCES BETWEEN PROTOCOL AND REVIEW . . . . . . . . . . . . . . . . . . . . . 126

Motivational interviewing for substance abuse (Review)

Copyright $(201$ I The Cochrane Collaboration. Published by John Wiley \& Sons, Ltd. 


\title{
[Intervention Review]
}

\section{Motivational interviewing for substance abuse}

\author{
Geir Smedslund ${ }^{1}$, Rigmor C Berg ${ }^{1}$, Karianne T Hammerstrøm ${ }^{1}$, Asbjørn Steiro ${ }^{1}$, Kari A Leiknes ${ }^{1}$, Helene M Dahl ${ }^{2}$, Kjetil Karlsen² \\ ${ }^{1}$ Norwegian Knowledge Centre for the Health Services, Oslo, Norway. ${ }^{2}$ Department of Clinical Psychiatry, Institute of Clinical \\ Medicine, Tromsø, Norway \\ Contact address: Geir Smedslund, Norwegian Knowledge Centre for the Health Services, Postboks 7004, St. Olavs plass, Oslo, N- \\ 0130, Norway. ges@nokc.no.
}

Editorial group: Cochrane Drugs and Alcohol Group.

Publication status and date: New, published in Issue 5, 2011.

Review content assessed as up-to-date: 27 March 2011.

Citation: Smedslund G, Berg RC, Hammerstrøm KT, Steiro A, Leiknes KA, Dahl HM, Karlsen K. Motivational interviewing for substance abuse. Cochrane Database of Systematic Reviews 2011, Issue 5. Art. No.: CD008063. DOI: 10.1002/14651858.CD008063.pub2.

Copyright @ 2011 The Cochrane Collaboration. Published by John Wiley \& Sons, Ltd.

\section{A B S T R A C T}

\section{Background}

There are 76.3 million people with alcohol use disorders worldwide and 15.3 million with drug use disorders. Motivational interviewing (MI) is a client-centred, semi-directive method for enhancing intrinsic motivation to change by exploring and resolving ambivalence. The intervention is used widely, and therefore it is important to find out whether it helps, harms or is ineffective.

\section{Objectives}

To assess the effectiveness of motivational interviewing for substance abuse on drug use, retention in treatment, readiness to change, and number of repeat convictions.

\section{Search strategy}

We searched 18 electronic databases, 5 web sites, 4 mailing lists, and reference lists from included studies and reviews. Search dates were November 30, 2010 for Cochrane Library, Medline, Embase and PsychINFO.

\section{Selection criteria}

Randomized controlled trials with persons dependent or abusing substance. Interventions were MI or motivational enhancement therapy. The outcomes were extent of substance abuse, retention in treatment, motivation for change, repeat conviction.

\section{Data collection and analysis}

Three authors independently assessed studies for inclusion, and two authors extracted data. Results were categorized into (1) MI versus no-treatment control, (2) MI versus treatment as usual, (3) MI versus assessment and feedback, and (4) MI versus other active treatment. Within each category, we computed meta-analyses separately for post-intervention, short, medium and long follow-ups.

\section{Main results}

We included 59 studies with a total of 13,342 participants. Compared to no treatment control MI showed a significant effect on substance use which was strongest at post-intervention SMD 0.79, (95\% CI 0.48 to 1.09 ) and weaker at short SMD 0.17 (95\% CI 0.09 to 0.26 ], and medium follow-up SMD 0.15 (95\% CI 0.04 to 0.25$]$ ). For long follow-up, the effect was not significant SMD 0.06 (95\% CI-0.16 to 0.28). There were no significant differences between MI and treatment as usual for either follow-up post-intervention, short and medium follow up. MI did better than assessment and feedback for medium follow-up SMD 0.38 (95\% CI 0.10 to 0.66 ). For short follow-up, there was no significant effect. For other active intervention there were no significant effects for either follow-up.

There was not enough data to conclude about effects of MI on the secondary outcomes. 


\section{Authors' conclusions}

MI can reduce the extent of substance abuse compared to no intervention. The evidence is mostly of low quality, so further research is very likely to have an important impact on our confidence in the estimate of effect and is likely to change the estimate.

\section{PLAIN LANGUAGE SUMMARY}

\section{Motivational interviewing is a short psychological treatment that can help people cut down on drugs and alcohol}

More than 76 million people worldwide have alcohol problems, and another 15 million have drug problems. Motivational interviewing (MI) is a psychological treatment that aims to help people cut down or stop using drugs and alcohol. The drug abuser and counsellor typically meet between one and four times for about one hour each time. The counsellor expresses that he or she understands how the clients feel about their problem and supports the clients in making their own decisions. He or she does not try to convince the client to change anything, but discusses with the client possible consequences of changing or staying the same. Finally, they discuss the clients' goals and where they are today relative to these goals. We searched for studies that had included people with alcohol or drug problems and that had divided them by chance into MI or a control group that either received nothing or some other treatment. We included only studies that had checked video or sound recordings of the therapies in order to be certain that what was given really was MI. The results in this review are based on 59 studies. The results show that people who have received MI have reduced their use of substances more than people who have not received any treatment. However, it seems that other active treatments, treatment as usual and being assessed and receiving feedback can be as effective as motivational interviewing. There was not enough data to conclude about the effects of MI on retention in treatment, readiness to change, or repeat convictions. The quality of the research forces us to be careful about our conclusions, and new research may change them. 


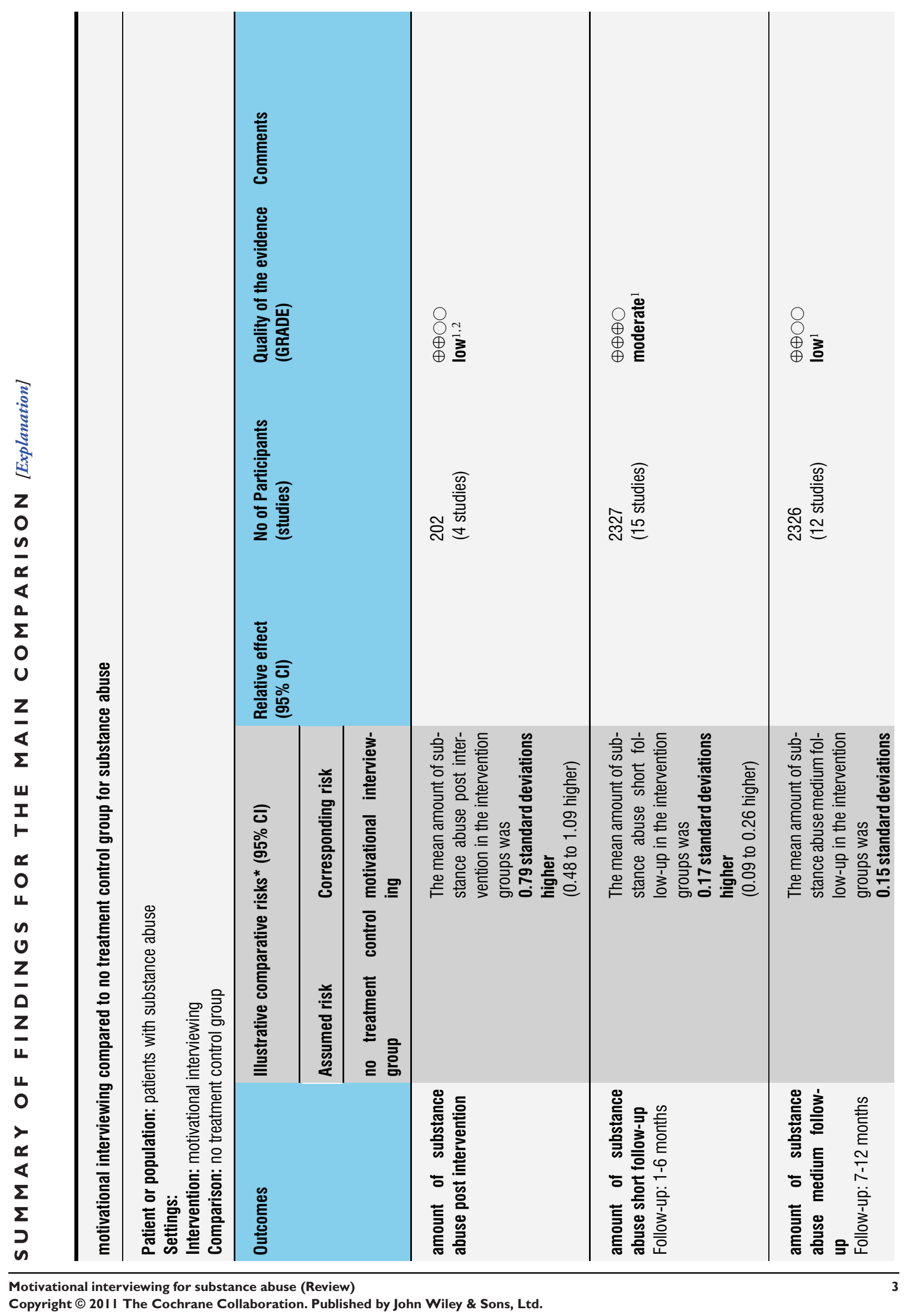




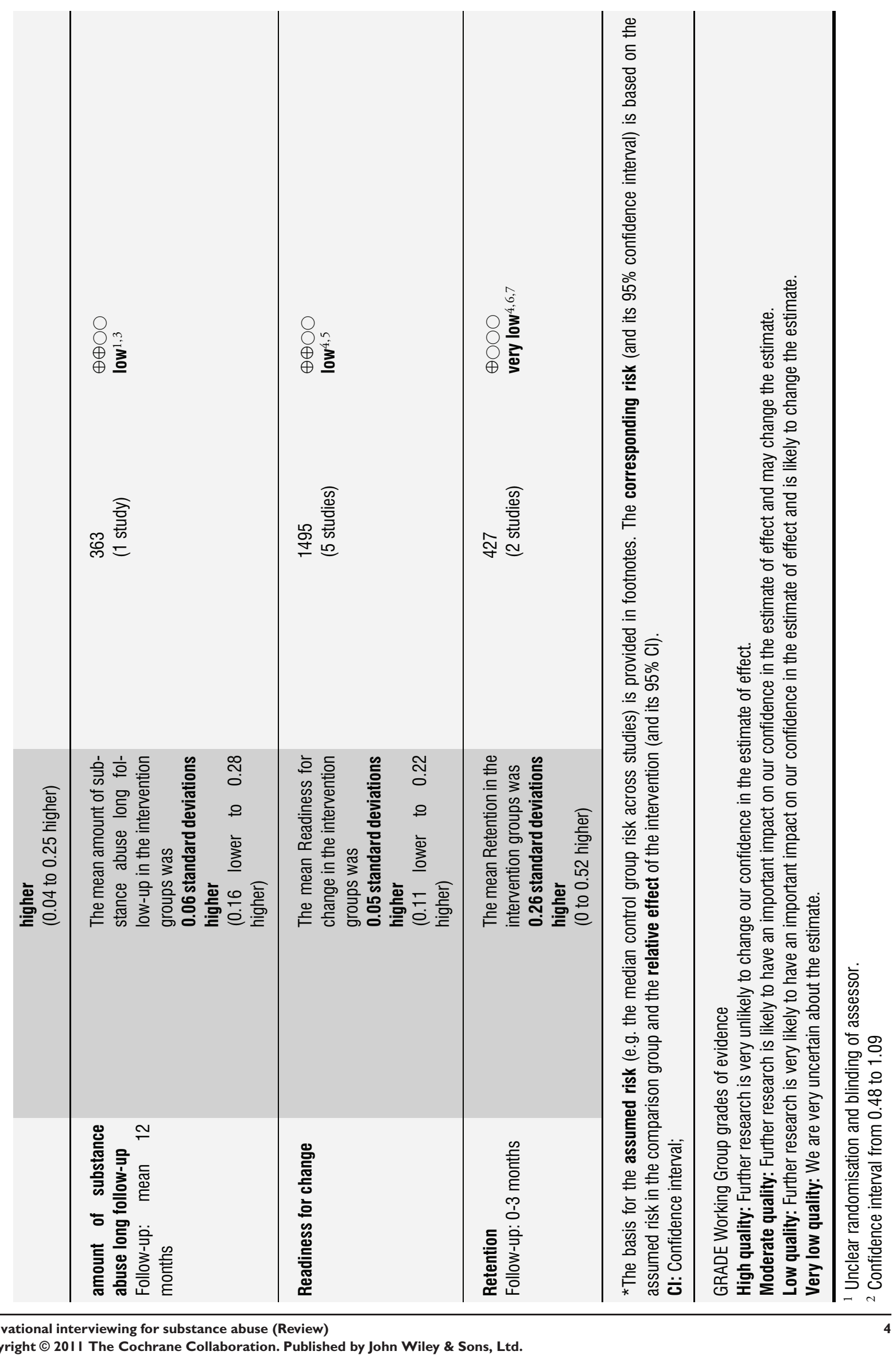




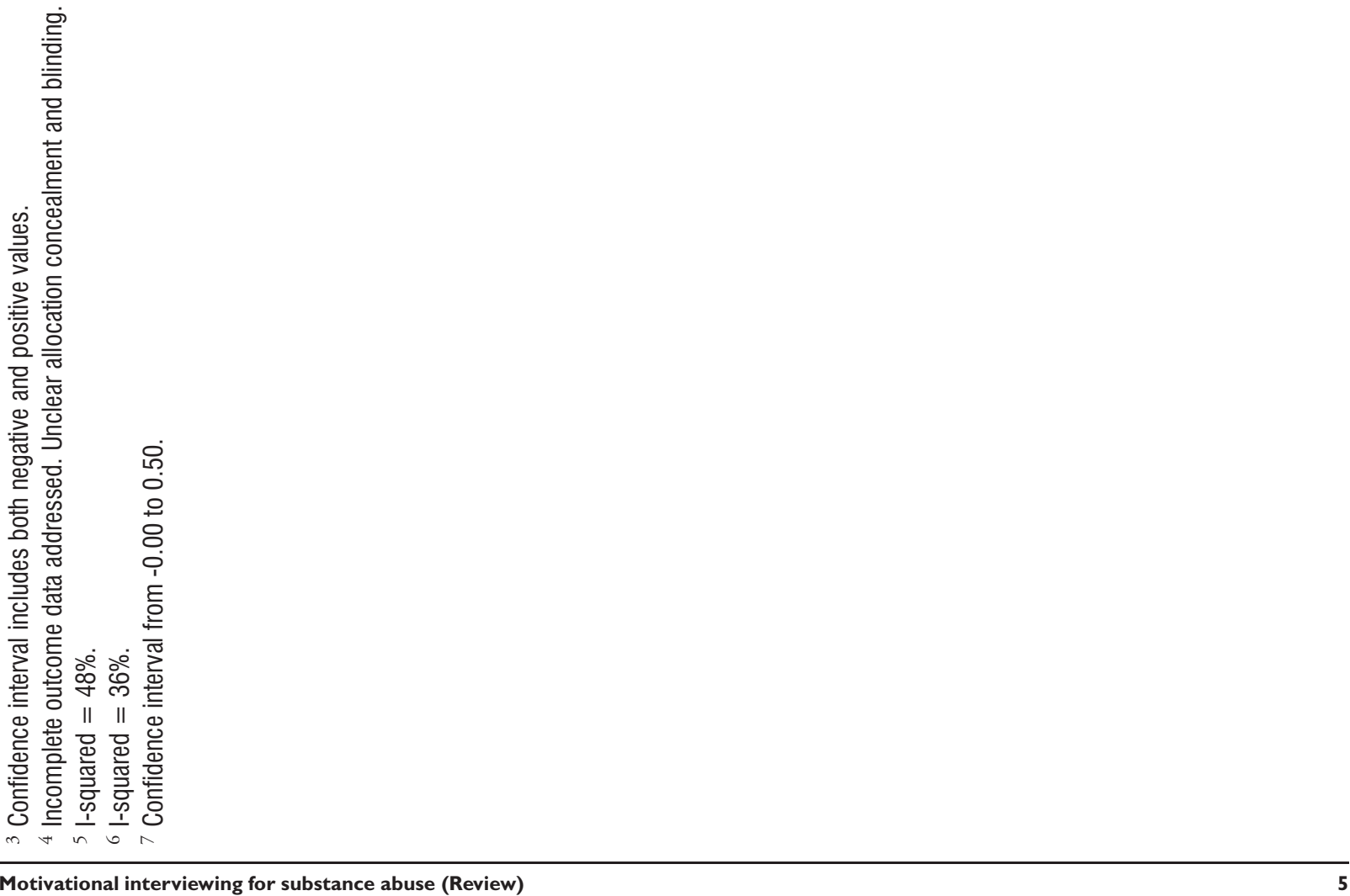

Motivational interviewing for substance abuse (Review)

Copyright ( 201 I The Cochrane Collaboration. Published by John Wiley \& Sons, Ltd. 


\section{B A C K G R O U N D}

\section{Description of the condition}

According to the World Health Organization (WHO 2009) there are 76.3 million people with alcohol use disorders worldwide. In addition, there are at least 15.3 million people who suffer from a drug use disorder, and injecting drug use is reported in 136 countries.

Substance abuse refers to the overindulgence in and dependence on a drug or other substance leading to effects that are detrimental to the individual's physical and mental health, or the welfare of others. The disorder is characterized by a pattern of continued pathological use of a drug or other substance, that results in repeated adverse social consequences related to drug use, such as failure to meet work, family, or school obligations, interpersonal conflicts, or legal problems. There are on-going debates as to the exact distinctions between substance abuse and substance dependence. We follow the definitions by the American Psychiatric Association (APA 2000) and distinguish between the two by defining substance dependence as a cluster of cognitive, behavioral, and physiological symptoms indicating that the individual continues use of the substance despite significant substance-related problems. There is a pattern of repeated self-administration that can result in tolerance, withdrawal, and compulsive drug-taking behavior (APA 2000). Substance abuse is a maladaptive pattern of substance use manifested by recurrent and significant adverse consequences related to the repeated use of substances. In order for an Abuse criterion to be met, the substance-related problem must have occurred repeatedly during the same 12-month period or been persistent.

Substance abuse may lead to addiction or substance dependence. Medically, physiologic dependence requires the development of tolerance leading to withdrawal symptoms. Both abuse and dependence are distinct from addiction which involves a compulsion to continue using the substance despite the negative consequences, and may or may not involve chemical dependency (APA 2000). Dependence almost always implies abuse, but abuse frequently occurs without dependence, particularly when an individual first begins to abuse a substance. There is also a distinction between "misuse" and "abuse" of substances. Substance misuse is the incorrect use of medication by patients, who may use a drug for a purpose other than that for which it was prescribed; or use of a substance for unintended purposes (APA 2000). The focus of this review is substance abuse, dependency or addiction, but not misuse.

\section{Description of the intervention}

Motivational interviewing (MI) was started by Miller (Miller 1983) and developed by Miller and Rollnick (Miller 1991). MI is a client-centred, semi-directive method for enhancing intrinsic motivation to change by exploring and resolving ambivalence. MI integrates the relationship-building principles of Carl Rogers (Rogers 1951) with more active cognitive-behavioural strategies. The intervention has four basic principles (described below). A brief variant of MI is called Motivational Enhancement Therapy (MET). MET is manual-based, and was developed as part of Project MATCH (Project MATCH 1997). Project MATCH was a large multi site trial comparing MI with cognitive behavioral therapy (CBT) and twelve-step facilitation therapy. MI counselling does not require professional training as nurse, psychologist, etc. Hence, MI may be incorporated in programmes run by health care staff as well as e.g. prison staff. There are explicit standards for practitioners regarding education and competence, and there is quality control to ensure that the method is in fact used as intended. One instrument for assessing treatment integrity is the Motivational Interviewing Treatment Integrity (MITI) scale (Moyers 2005). For a description of various measures of treatment fidelity in MI, we recommend the review by Madson and Campbell (Madson 2006). Promising results have been reported as to the effect of the method for alcohol dependence, smoking cessation, drug addiction, HIV-risk behaviours, treatment adherence, diet $\&$ exercise, and eating disorders (Carey 2007; Burke 2004 ; Hettema 2005; Rubak 2005). MI has recently been introduced into the criminal justice system, in Europe as well as in NorthAmerica. In the research literature, the most widely used approach related to MI has been one in which the client is given feedback based on individual results from standardized assessment measures or a modification of it. Burke et al. (Burke 2003) considered this feedback-based approach to constitute an adaptation of motivational interviewing (AMI) because it is defined by the presence of the feedback component and not solely by the use of motivational interviewing per se. More broadly, they also applied the term AMI to interventions that incorporate additional non-motivational interviewing techniques while retaining motivational interviewing principles as the core of treatment as well as to interventions that have been specifically adapted for use by non-specialists.

\section{How the intervention might work}

MI is intended to work through its four main principles: (1) express empathy, (2) support self-efficacy, (3) roll with resistance, and (4) develop discrepancy. As expressed on the official homepage of Motivational Interviewing (http://motivationalinterview.org/ clinical/principles.html), expressing empathy involves seeing the world through the client's eyes. Supporting self-efficacy means that clients are held responsible for choosing and carrying out actions to change. The third principle, rolling with resistance, means that the counsellor does not fight client resistance, but "rolls with it." Statements demonstrating resistance are not challenged. Instead the counsellor uses the client's "momentum" to further explore the client's views. Lastly, motivation for change occurs when people 
perceive a discrepancy between where they are and where they want to be. MI counsellors work to develop this situation through helping clients examine the discrepancies between their current behavior and future goals. When clients perceive that their current behaviours are not leading toward some important future goal, they become more motivated to make important life changes. Apodaca and Longabaugh (Apodaca 2009) did a literature search to identify potential within-session mechanisms of change in MI. The most consistent evidence was found for three constructs: client change talk/intention (related to better outcomes); client experience of discrepancy (related to better outcomes); and therapist MI-inconsistent behavior (related to worse outcomes).

\section{Why it is important to do this review}

The intervention is used widely, and therefore it is important to find out whether it helps, harms or is ineffective. Several reviews and meta-analyses have been published (e.g. Andreasson 2003; Burke 2003; Burke 2004; Carey 2007; deWildt 2002; Dunn 2001; Emmelkamp 2006; Grenard 2006; Hettema 2005; Larimer 2007; Lundahl 2010; Nahom 2005; Rubak 2005; Vasilaki 2006 ) but they all differ somewhat from our review. Some of them have studied effects of MI (AMI) on other groups in addition to substance abusers or studied only alcohol abusers. Others included other designs in addition to randomised trials. The main strengths of the present review are that it employs a comprehensive and systematic search strategy aiming to be exhaustive, and that it includes only randomized controlled trials. We will also assess the risk of bias of the included studies and grade the evidence for the primary outcomes.

\section{O B JECTIVES}

To assess the effectiveness of motivational interviewing, as a primary or support intervention, for substance abuse, in terms of levels of drug use, retention in treatment, and readiness for change.

\section{METHODS}

\section{Criteria for considering studies for this review}

\section{Types of studies}

We included studies where units (persons, therapists, institutions) were allocated randomly or quasi-randomly to motivational interviewing or other conditions. Included studied had to be published in or after 1983, which was the year that MI was introduced. We had no limitation on length of study. We excluded studies that recruited participants in emergency rooms and provided one session of MI during the stay in the emergency room.

\section{Types of participants}

Persons defined as having either substance abuse, dependency or addiction, but not misuse. There were no limitations on age or other participant characteristics. The term substance refers to a drug of abuse, a medication, a toxin or alcohol, excluding nicotine. The reason for excluding nicotine, is that there is an existing Cochrane review on motivational interviewing for smoking cessation (Lai 2010). According to International classification of Diseases version 10 (ICD-10) (WHO 1993) we included the following codes, F10 to F19*, excluding F15 (caffeine) and F17 (tobacco). Equivalent disorders and codes in the Diagnostic and Statistical Manual of Mental Disorders, third revised edition (DSMIII-R) (APA 1987) and fourth edition, (DSM-IV) (APA 1994), chapter Substance-Related disorders, were also included. We also included studies in which substance abuse was not formally diagnosed. Participants could be dual diagnosis clients. We included both participants who only abuse substances and participants who also have mental problems, but we analysed the two groups separately.

* [Mental and behavioural disorders due to use of - alcohol (F10 - 303), - opioids (F11), - cannabinoids (F12), - sedatives or hypnotics (F13), - cocaine (F14), - other stimulants (amphetamine) (F15), - hallucinogens (F16), - volatile solvents (F18) and - multiple drug use and use of other psychoactive substances (F19).]

\section{Types of interventions}

\section{Experimental intervention}

Primarily, the interventions should be labelled motivational interviewing $(\mathrm{M})$ ) or motivational enhancement therapy (MET). The intervention could basically be offered in three ways: (1) as a standalone therapy, (2) MI integrated with another therapy, or (3) MI as a prelude to another therapy (e.g. cognitive behavioral therapy). Only individual, face-to-face interventions were included. We excluded group interventions, and interventions not given in person (e.g. computer-delivered or telephone interventions). Because most psychosocial interventions have many unspecific elements in common, and because terms like "motivational intervention" and "motivational interview" not necessarily refers to Miller's specific program of MI, we included only studies that reviewed audio or video recordings to ensure that the intervention given was indeed MI.

Studies had to include checks of audio- or videotaping of sessions in order to assess fidelity of treatment.

\section{Control intervention}

The comparator could be no intervention, waiting list control, placebo psychotherapy or other active therapy. 


\section{Types of outcome measures}

Data on substance abuse could be both dichotomous (number of participants ceasing substance abuse) and continuous (e.g. mean number of days used in last 30 days). Substance abuse could also be measured using various scales or inventories like the OTI (Opiate Treatment Index) (Darke 1991; Darke 1992), the Timeline Follow-Back (Sobell 1992), and the Rutgers Alcohol Problems Index (RAPI; White 1989).

\section{Primary outcomes}

- cease of substance use measured by self-report, report by collaterals, urine analysis, or blood samples, etc.

- reduction in substance abuse measured as above.

Outcomes are typically recorded as a posttest immediately after the interventions ended, short-term follow-ups until six months after the intervention ended, medium-term follow-ups of between six and 12 months, and long-term follow-ups of 12 months or longer. The exact follow-up durations are recorded for each study.

\section{Secondary outcomes}

- Retention in treatment.

- Improve motivation for change, e.g. measured by the Readiness to Change Questionnaire (RCQ; Heather 1993).

- Number of repeat convictions (for convicted substance abusers)

\section{Search methods for identification of studies}

\section{Electronic searches}

We searched the following electronic databases: Medline (1950 to November Week 3, 2010), Embase (1980 to 2010, week 4), PsycInfo (1806 to November week 4, 2010), PsychExtra (1908 to January 14, 2008), Cochrane Central Register of Controlled Trials (search date: November 30, 2010), C2-SPECTR (Search date: November 23, 2009), International Bibliography of the Social Sciences (1951 to November week 3, 2009), Sociological Abstracts (search date: November 30, 2010), ISI Web of Science (search date: November 30, 2010), SveMed+ (search date: November 30, 2010), CINCH (search date: November 30, 2010), NCJRS (search date: November 30, 2010), SpringerLink (search date: October 2, 2010), Wiley Interscience (search date: October 2, 2010), DrugScope Library (search date: October 2, 2010), Electronic Library of the National Documentation Centre on Drug Use (search date: October 2, 2010), Google Scholar, and Google (search date: February 2, 2010). Year of publication was limited to 1983 and later.

Databases were searched using a strategy developed incorporating the filter for the identification of RCTs (Higgins 2009) combined with selected $\mathrm{MeSH}$ terms and free text terms relating to substance abuse and motivational interviewing. The MEDLINE search strategy was translated into the other databases using the appropriate controlled vocabulary as applicable. The search strategies for all databases are shown in Appendix 1.

We searched the following web sites and mailing lists: Websites:

- www.motivationalinterview.org (bibliography updated November 2009)

- http://nrepp.samhsa.gov/programfulldetails.asp?

PROGRAM_ID=182 (accessed June 7th, 2010)

- http://www.controlled-trials.com (accessed August 24th, 2010)

- http://clinicalstudyresults.org (accessed August 24th, 2010

- http://centrewatch (accessed August 24th, 2010).

\section{Mailinglists:}

- MINT-listserv; a mailing list available to members of

MINT (Motivational Interviewing Network of Trainers)

- Australian Criminology Listserv

- Campbell Crime\& Justice Group Steering Committee

- Crimnet. http://www.law.usyd.edu.au/mailman/listinfo/ crimnet.

We had no language restrictions.

\section{Searching other resources}

References in obtained reviews and included primary studies were searched (in June 2010) to identify new leads.

\section{Data collection and analysis}

\section{Dealing with dependent data}

When there was more than one intervention group that was compared with a single control group, we did not include both comparisons in the same meta-analysis. When there were several follow-up times, we categorised them into post, short, medium or long follow-up as described above. In cases when there were data from more than one follow-up time within one of our categories, we used the mean value. When there was more than one measure of the same outcome, we used the standardised mean value.

\section{Selection of studies}

The screening of studies proceeded in 3 levels. At Level 1, two reviewers who were methodologists scanned the titles of each reference. Each reviewer scored either "promote to next level", "exclude" or "can't tell". Only if both reviewers scored "exclude" was the reference excluded. If at least one reviewer scored "can't tell" or "include", the reference was promoted to Level 2. At Level 2, the titles and abstracts were read, and the same promotion rules applied. References promoted to Level 3 were ordered in full text. Two reviewers read the full texts and scored "include" or "exclude". 
If there were disagreement, and the two reviewers could not agree, a third reviewer decided whether to include the study.

\section{Data extraction and management}

Data from each study were extracted by two reviewers using a specifically developed data extraction form (available on request). The reviewers had full access to details about authors, institutions, and journals at all times. The same rules for tackling disagreement as at Level 3 applied. If information about primary outcomes or other vital information was missing from the original reports, we contacted the corresponding author by e-mail (up to three times) in an attempt to retrieve the necessary data for the analysis. In cases where effect size information could not be obtained from the authors of the primary studies, we used effect size data from published systematic reviews and meta-analyses, when available. If necessary, we contacted the authors of the systematic reviews/ meta-analyses for additional information.

\section{Assessment of risk of bias in included studies}

The risk of bias assessment for RCTs and CCTs (controlled clinical trials) in this review was performed using the six criteria recommended by the Cochrane Handbook (Higgins 2009). The recommended approach for assessing risk of bias in studies included in Cochrane Reviews is a two-part tool, addressing six specific domains (sequence generation, allocation concealment, blinding, incomplete outcome data, selective outcome reporting, and other issues). The first part of the tool involves describing what was reported to have happened in the study. The second part of the tool involves assigning a judgement, in terms of "low ", "high" or "unclear", relating to the risk of bias for that entry. To make these judgments we used the criteria indicated by the handbook adapted to the addiction field.

Blinding of participants and providers was assessed as one item, while blinding of outcome assessor was assessed as another item. Incomplete outcome data (avoidance of attrition bias) were considered for all outcomes except for the drop out from the treatment, which is very often the primary outcome measure in trials on addiction. It is assessed separately for results at the end of the study period and for results at follow up.

The criteria for assessing other bias were: differences between groups at baseline, collateral and biological measurement to corroborate self-reports of substance abuse, differences in providers' time spent in training between conditions, and contamination of conditions. In addition, we looked for other sources of bias in each study.

\section{Grading of evidence}

The quality of evidence was assessed according to a systematic and explicit method (Guyatt 2008). In order to indicate the extent to which one can be confident that an estimate of effect is correct, judgments about the quality of evidence are made for each comparison and outcome. These judgments consider study design
(RCT, quasi RCT or observational study), study quality (detailed study design and execution), consistency of results (similarity of estimates of effect across studies), precision of estimates, and directness (the extent to which people, interventions and outcome measures are similar to those of interest). The following definitions in grading the quality of evidence for each outcome are used: High: further research is very unlikely to change our confidence in the estimate of effect. Moderate: further research is likely to have an important impact on our confidence in the estimate of effect and may change the estimate. Low: further research is very likely to have an important impact on our confidence in the estimate of effect and may change the estimate. Very low: any estimate of effect is very uncertain.

\section{Measures of treatment effect}

We compared the treatment and control groups for outcomes at post-test and at different follow-up times. Post-intervention data were collected immediately after the intervention ended. Short follow-up was until (but not including) 6 months. Medium follow-up was from 6 months until (but not including) 12 months. Long follow-up was 12 months and longer. For dichotomous data, we computed relative risks (risk ratios). For continuous data we computed standardised mean differences. 95 percent confidence intervals were used as measures of the amount of random errors influencing the outcome estimations. We used the optimal information size (OIS) (Pogue 1997) for assessing whether there is a sufficient sample size for concluding that there is a statistically significant effect in a meta-analysis. Using a two-sided alpha of 0.01 and power of 0.95 we calculated that a total sample size of 1,786 is necessary for detecting a small standardised mean difference $(\mathrm{SMD}=0.2)$. For SMDs of 0.5 (medium) and 0.8 (large), the OIS are 290 and 116, respectively.

\section{Unit of analysis issues}

In cluster-randomised trials, the elements are groups of individuals (e.g. prisons, geographical areas, clinics), rather than individuals themselves. In such studies, care should be taken to avoid unitof-analysis errors. If there for instance are a total of 100 substance abusers with 25 abusers in each of four clinics, and two clinics are randomised to receive the intervention and the other two are randomised to receive the control, the correct $\mathrm{N}$ to use in the analysis is not 100 but smaller. The effective sample size of a single intervention group in a cluster-randomised trial is its original sample size divided by a quantity called the design effect. A common design effect is usually assumed across intervention groups. The design effect is $1+(m-1) r$, where $m$ is the average cluster size and $r$ is the intra cluster correlation coefficient (ICC). If we include any cluster randomised controlled trials in this review, we try to measure the intra-cluster correlation. The total variance in the outcome can be partitioned into variance between groups (VBG) and variance within groups (VWG).The intra cluster correlation is calculated 
as VBG/(VBG+VWG). But the ICC is seldom reported in the primary studies. The number of participants can be used in the analyses if the ICC is used as a correcting factor. For dichotomous data both the number of participants and the number experiencing the event can be divided by the same design effect (Higgins 2008).

\section{Dealing with missing data}

We contacted authors by email (up to three times) to collect missing data. Statisticians often use the terms 'missing at random', and 'not missing at random' to represent different scenarios. Data are said to be 'missing at random' if the fact that they are missing is unrelated to actual values of the missing data. Data are said to be 'not missing at random' if the fact that they are missing is related to the actual missing data. In cases where we assumed that data were missing at random, we analysed only the available data. If we assumed that the data were not missing at random, we planned to impute the missing data with replacement values, and treat these as if they were observed. We planned to do this in different ways and compare the results (e.g. last observation carried forward, imputing an assumed outcome such as assuming all were poor outcomes, imputing the mean, imputing based on predicted values from a regression analysis). For the included studies in this review we did not impute data.

\section{Assessment of heterogeneity}

Statistically significant heterogeneity among primary outcome studies was assessed with Chi-squared (Q) test and I-squared (Higgins 2003). A significant $Q(p<.05)$ and I-squared of at least $50 \%$ was considered as statistical heterogeneity.

\section{Assessment of reporting biases}

We used funnel plots for information about possible publication bias. But asymmetric funnel plots are not necessarily caused by publication bias (and publication bias does not necessarily cause asymmetry in a funnel plot). Whenever asymmetry was present, likely reasons were explored.

\section{Data synthesis}

When meta-analyses were performed, we reported random effects meta-analyses. If meta-analyses were not judged to be appropriate, we reported the results for each individual study.

\section{Subgroup analysis and investigation of heterogeneity}

We investigated the following factors with the aim of explaining observed heterogeneity (if present): Students or non-students as participants, type of fidelity check, type of substance, intensity or length/period of the intervention, whether Intervention was MI or MET, whether a manual was used, profession of therapist. We also compared results for studies with or without the developers of MI William R. Miller or Stephen Rollnick on the author list or mentioned as mentors or trainers (including training by a member of MINT [Motivational Interviewing Network of Trainers]). We analysed effects separately for MI alone, MI integrated with other therapy, and MI given as a prelude to other therapy.

When there were many primary studies, we classified them according to these variables in order to identify possible sources of heterogeneity. We considered performing moderator analyses (stratification on subgroups, meta-analysis analogue to ANOVA, metaregression) to explore how observed variables were related to heterogeneity.

\section{Sensitivity analysis}

When there was significant unexplained heterogeneity and the number of included studies was sufficient (more than 10), we assessed the impact of differing risk of bias by sensitivity analyses. The following sensitivity analyses were planned a priori: Generation of allocation sequence, concealment of allocation, blinding of patients and providers, blinding of assessors, incomplete outcome data addressed, selective reporting, and other bias.

\section{R E S U L T S}

\section{Description of studies}

See: Characteristics of included studies; Characteristics of excluded studies; Characteristics of studies awaiting classification; Characteristics of ongoing studies.

See Characteristics of included studies; Characteristics of excluded studies.

\section{Results of the search}

Our electronic search in November 2009 returned 1,801 records, and an updated search in November 2010 produced an additional 518 records. One record (Emmen 2005) was located through www.motivationalinterview.org. No additional records were found while searching reference lists of included studies (in June 2010), thus making the total 2,320. We excluded 2077 records on the basis of title and abstract. We acquired full reports of 243 records (describing 208 studies). A total of 153 excluded records (describing 149 studies) are listed in the Characteristics of excluded studies.

\section{Included studies}

We identified 59 studies (reported in 90 articles) published between 1993 and 2010 for inclusion in this review, covering 13,342 
participants. 57 studies were RCTs, and two studies were quasiRCTs (Bazargan-Hejazi 2005; Freyer-Adam 2008). We did not locate any cluster-RCTs. Full details of all the included studies are given in a table (Characteristics of included studies). In 29 studies the participants seemed to be exclusively alcohol abusers, and in eight studies they were cannabis abusers. In four studies the participants were exclusively cocaine abusers, and in the remaining 18 studies, the participants were abusing more than one substance. We were not able to assess the severity of substance abuse across studies from the information reported in the included articles. There were 44 studies from the USA, five from Australia, three each from the Netherlands and UK, two from Canada, and one each from Germany and New Zealand.

\section{Excluded studies}

We excluded 149 studies (reported in 153 articles) read in full text. 39 studies did not report fidelity checks using video- or audio recordings. For 31 studies, substance abuse was not an outcome, and 28 studies did not seem to have given MI, MET or AMI. There were 21 studies that were not randomised trials, and 14 were not individualized, face-to-face interventions. Nine studies did not have substance abusers as participants, three studies did not compare MI with another condition, one study recruited and treated participants with one session MI in an emergency room, and two publications reported no results. One study had use of prescription drugs as outcome. The excluded trials are listed in the table Characteristics of excluded studies, with main reasons for their exclusion.

\section{Risk of bias in included studies}

Full details of risk of bias assessments are given for each trial within the Characteristics of included studies table. Overall summary results of all the risk of bias assessments are displayed in Figure 1. A summary of the risk of bias for each study and each domain is given in Figure 2.

Figure I. Methodological quality graph: review authors' judgements about each methodological quality item presented as percentages across all included studies.

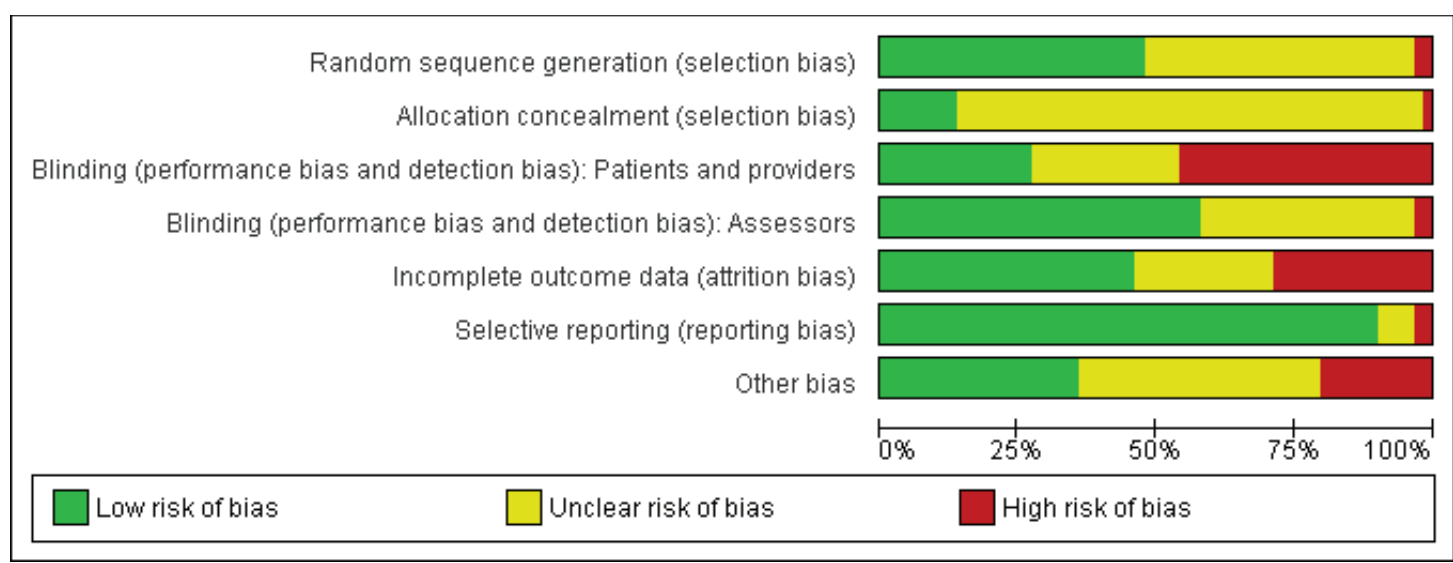


Figure 2. Methodological quality summary: review authors' judgements about each methodological quality item for each included study.

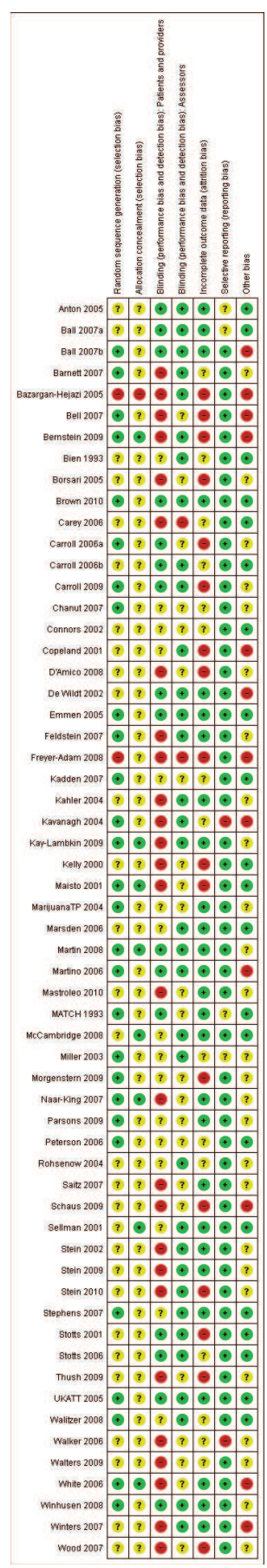




\section{Allocation}

28 studies were at low risk of selection bias because they used an adequate method of sequence generation, but for 29 studies the generation method is unclear. A minority of studies have obviously not used adequate generation of allocation $(n=2)$. For most of the studies there is an inadequate description of what, if anything, was done to conceal the allocation $(n=50)$ and were therefore judged as having unclear risk of bias.

\section{Blinding}

In psychological therapies like MI, it is not possible to blind the people giving the intervention. It is also not generally possible to blind the participants. An exception might be if there is an active control, like another type of psychological therapy. In 27 of the 59 studies we believe that there was a high risk of bias because participants and/or providers knew who were in the intervention group. In the majority of studies $(\mathrm{n}=31)$ it was unclear whether the assessors were blinded. In 22 studies the assessors appear to have been adequately blinded.

For the primary outcomes we have treated physiological and nonphysiological outcomes separately. Non-blinding of physiological outcomes produces less risk of bias than the non-physiological ones. The secondary outcomes (retention in treatment, readiness for change, and re conviction) were all non-physiological.

\section{Incomplete outcome data}

We used the following rules of thumb for the judgement of risk of bias: loss-to-follow-up equal to or greater than 20 percent, different rates of follow-up across intervention arms, reasons for loss-tofollow-up not reported, and intention-to-treat not performed. 27 studies had adequately accounted for incomplete outcome data. For 15 studies it was unclear, and for 17 studies there was a high risk of bias for this item.

\section{Selective reporting}

Most studies ( $\mathrm{n}=53$ ) were judged to be free of selective reporting.

\section{Other potential sources of bias}

A small number of studies $(n=12)$ was judged to have other potential sources of bias. 21 studies were judged to be of low risk of bias, and 26 studies were judged to be of unclear risk with respect to other sources of bias.

\section{Publication bias}

Figure 3; Figure 4; Figure 5; Figure 6 show funnel plots of the four main meta-analyses. For MI versus no intervention and for MI versus treatment as usual, it appears that smaller studies tend to have larger effect sizes in favour of MI. This could be (but not necessarily) a sign of publication bias. There is a possibility that small studies with non-significant results are less likely to be published. For MI versus assessment and feedback and for MI versus other active treatment, the funnel plots look more symmetric. 
Figure 3. Funnel plot of comparison: I MI versus no intervention, outcome: I.I Amount of substance use.

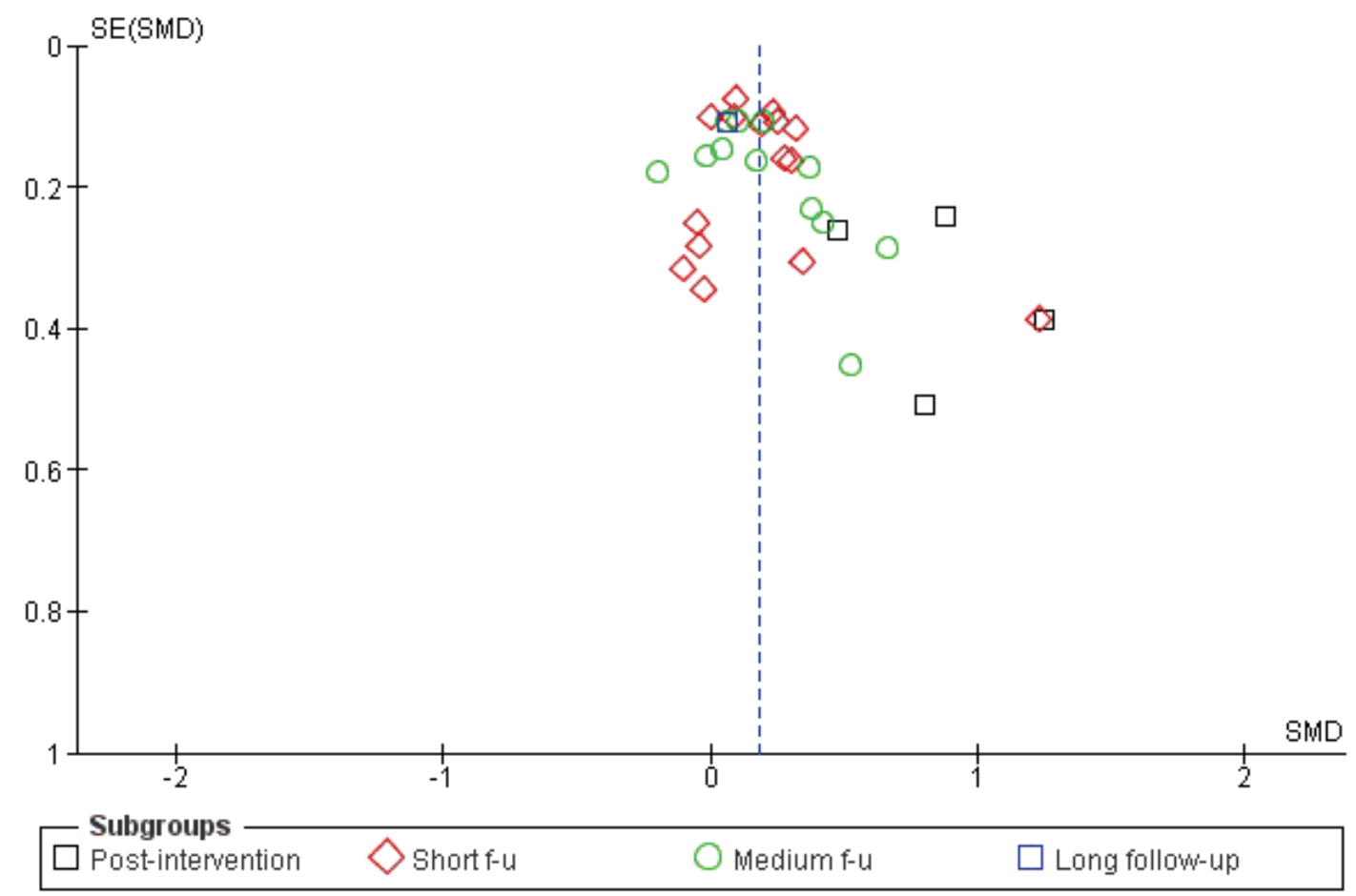


Figure 4. Funnel plot of comparison: $4 \mathrm{MI}$ versus treatment as usual, outcome: 4.I Amount of substance use.

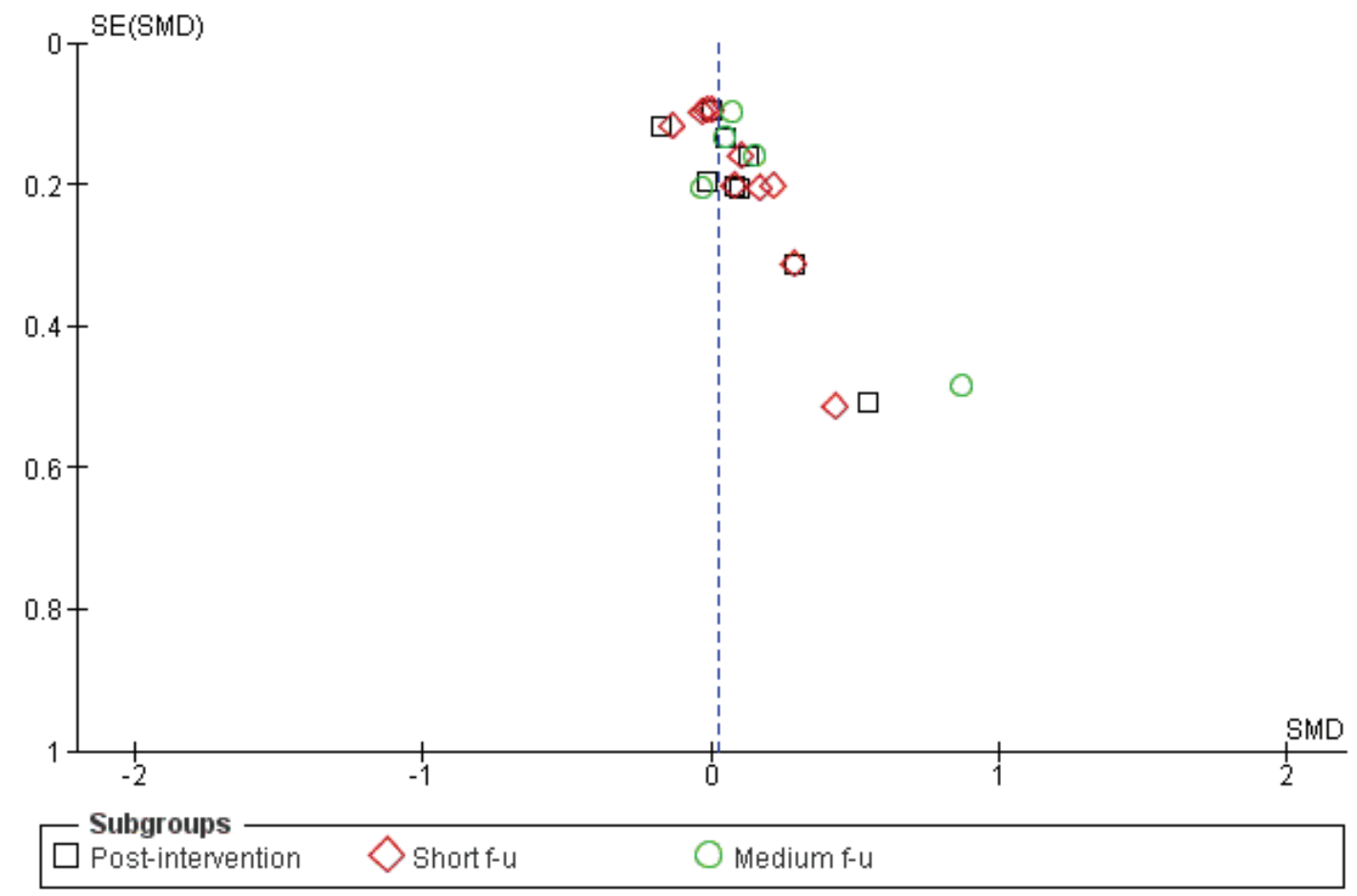


Figure 5. Funnel plot of comparison: 2 MI versus assessment and feedback, outcome: 2.I Amount of substance use.

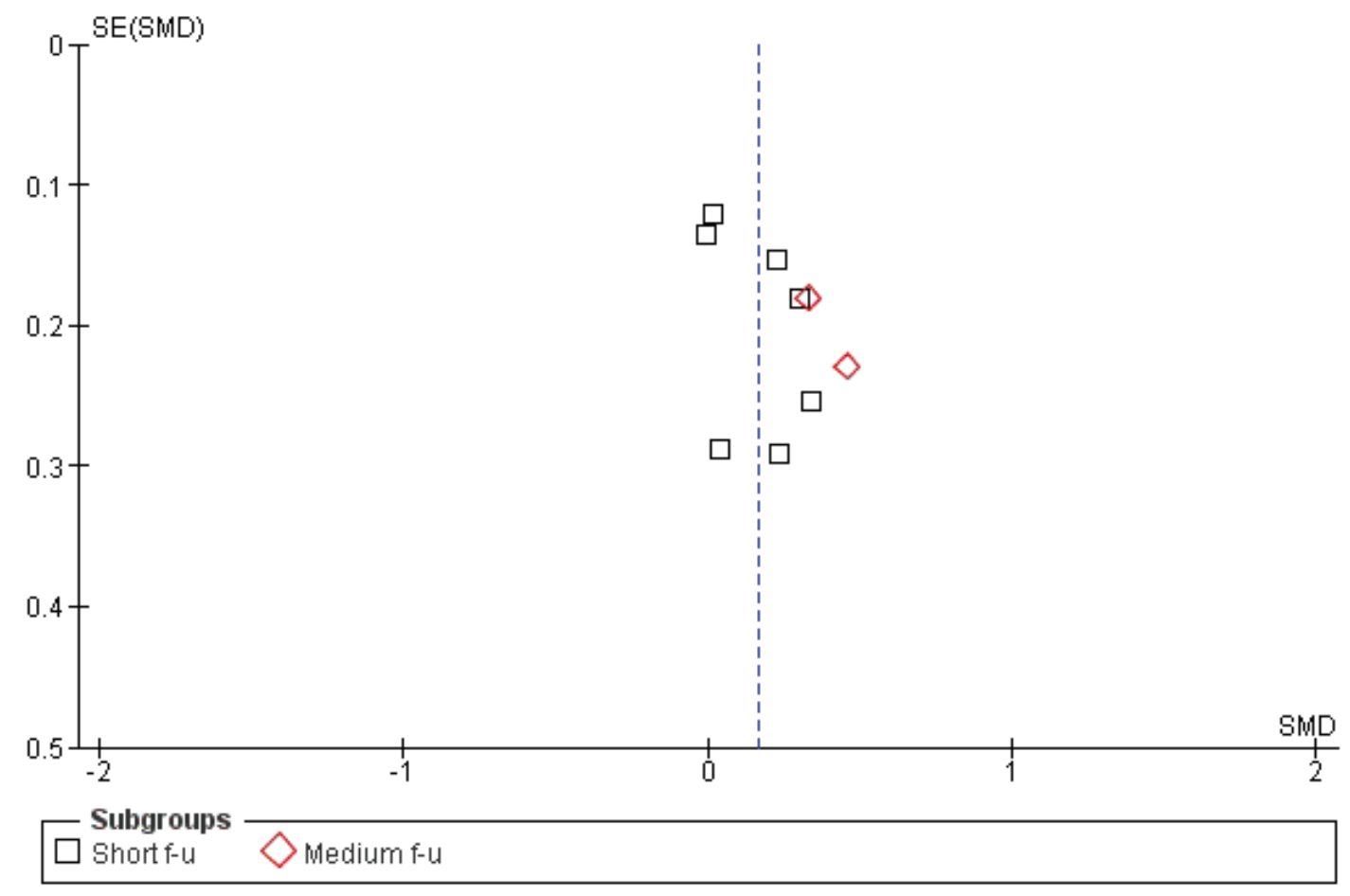


Figure 6. Funnel plot of comparison: $3 \mathrm{MI}$ versus other active intervention, outcome: 3.I Amount of substance use.

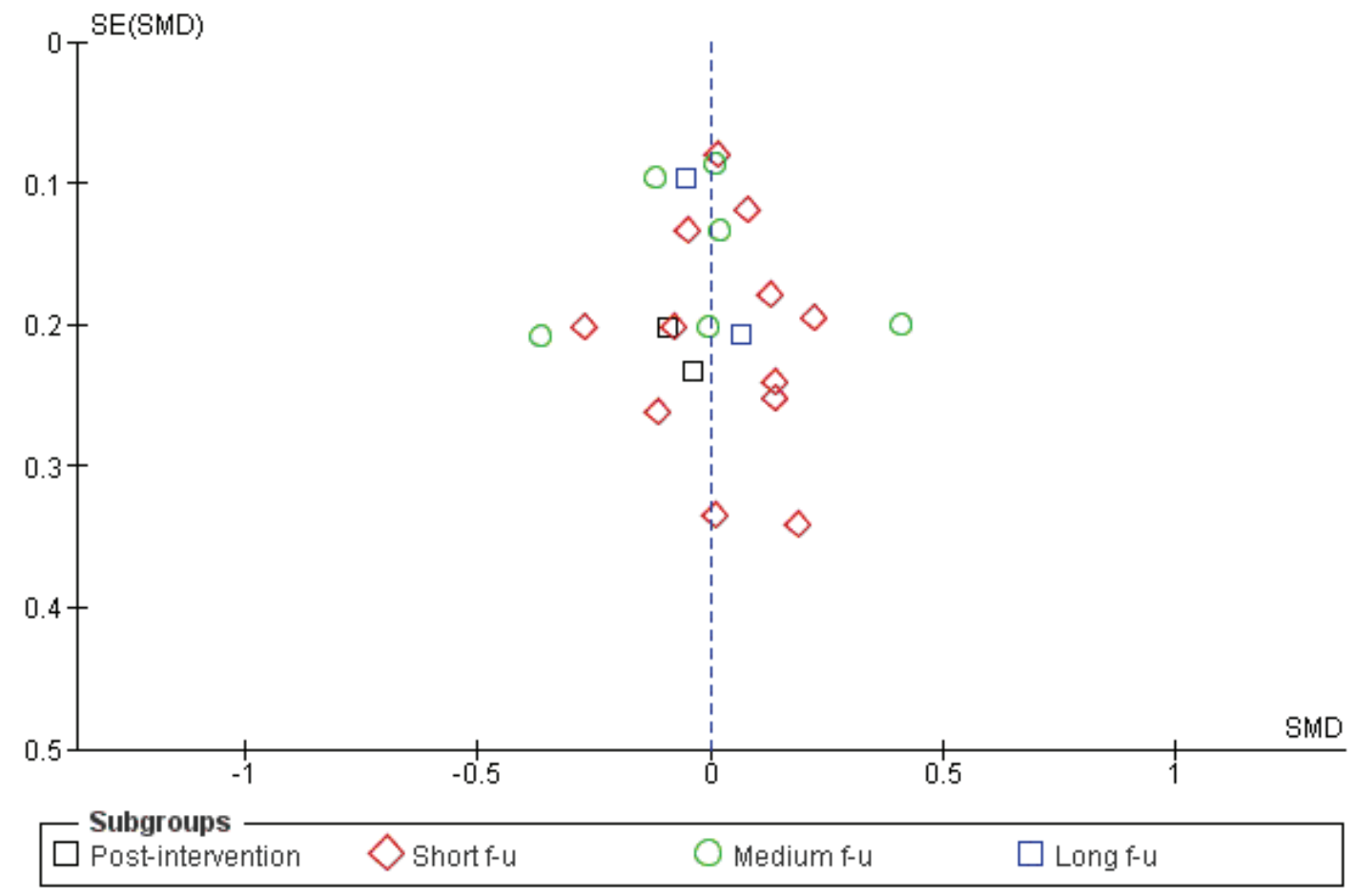

\section{Effects of interventions}

See: Summary of findings for the main comparison motivational interviewing compared to no treatment control group for substance abuse; Summary of findings 2 motivational interviewing compared to treatment as usual for substance abuse; Summary of findings 3 motivational interviewing compared to assessment and feedback for substance abuse; Summary of findings 4 motivational interviewing compared to other active intervention for substance abuse

Of the 59 included studies, we were able to extract outcome data from 55. For the remaining four studies (Parsons 2009; Rohsenow 2004; Stotts 2001; Thush 2009), the data in the articles were not reported in the form of an effect size and it was not possible to compute one, even after contacting the authors. Two studies (Walitzer 2008; Wood 2007) included two types of comparisons. The substance abuse outcomes were reported as a large number of different outcomes (e.g. drinks per drinking day, number of abstinent days, proportion of participants who were abstinent). Moreover, for each outcome the data were reported in a number of ways (e.g. means and SDs, number of events, p-values, F-values). We en- tered all the data in Comprehensive Meta-Analysis 2.0 (Borenstein 2005), which can accept data input in 100 different formats, and converted all outcome data into standardised mean differences. If a study had more than one substance abuse outcome at the same follow-up time or if a study reported the same outcome at more than one follow-up within our follow-up categories, we computed the mean. Finally, the data were entered into RevMan as generic inverse variance data. As a control procedure, we have grouped the outcomes into amount of use, frequency of use, and proportion abstinent. These analyses did not reveal any significant differences between the subgroups, and we do not report the results of metaanalyses.

In the following we have divided comparisons into (1) MI versus no intervention, (2) MI versus treatment as usual, (3) MI versus assessment and feedback, and (4) MI versus other active intervention. Within each comparison we have subgroups according to follow-up time: (a) post-intervention, (b) short follow-up until 6 months, (c) medium follow-up 6-12 months, and (d) long followup of 12 or more months.

\section{Comparison 1: MI versus no intervention}

There were 24 studies that compared MI with a no-treatment control. 


\section{Primary outcomes}

1.1 Extent of substance use:

Post-intervention: Four studies, 202 participants showed that MI did significantly better than the control on reducing the amount of substance use with a standardized mean difference of $0.79(95 \%$ CI 0.48 , to 1.09 ). Heterogeneity was low (I-square: $1 \%)$. Short follow-up: 15 studies, 2327 participants, showed that MI did significantly better than the control group SMD 0.17 (95\% CI 0.09 to 0.26 ). There was some variability in effect sizes (Chisquared $=18.4, \mathrm{df}=14, \mathrm{P}=0.19$, I-square $=24 \%$ ), but not exceeding our predetermined criteria for significant heterogeneity. Medium follow-up: Twelve studies, 2326 participants, showed a significant difference in favour of MI SMD 0.15 (95\% CI 0.04 to 0.25 ). The results varied somewhat (Chi-squared $=14.06, \mathrm{df}=11, \mathrm{I}$-squared $=$ $22 \%$ ) but again not exceeding our criteria. Long follow-up: One study, 363 participants, found no significant differences between the groups SMD 0.06 (95\% CI -0.16 to 0.28). See Analysis 1.1 Secondary outcomes

1.2 Readiness for change:

Five studies (Analysis 1.2) . There was no significant effect SMD 0.05 (95\%CI -0.11 to 0.22 ), and heterogeneity was moderate with I-square of $48 \%$.

1.3 Retention in treatment:

Five studies considered this outcome, but we could only compute effect sizes for two studies, 427 participants (Analysis 1.3). The effect was not significant SMD 0.26 (95\%CI -0.0 to 0.52 ).

Comparison 2. MI versus treatment as usual (TAU)

\section{Primary outcomes}

\section{$\underline{2.1 \text { Extent of substance use: }}$}

en studies considered this outcome . Post-intervention: Nine studies, 1495 participants, showed a non-significant effect SMD 0.01 (95\% CI -0.09 to 0.11) with an I-squared of 0\%. Short follow-up: Ten studies, 2102 participants, showed a non-significant effect SMD 0.01 (95\% CI-0.08 to 0.10]) with an I-squared of $0 \%$. Medium follow-up: Five studies, 890 participants, showed a non-significant effect 0.08 (95\% CI -0.05 to 0.21$])$ with an Isquared of $0 \%$. See Analysis 2.1

\section{Secondary outcomes}

\subsection{Retention in treatment:}

Five studies reported retention in treatment, but we were able to compute an effect size for only four of them, 1354 participants (Analysis 2.2). The effects were heterogenous (I-sqared: 64\%) and not significant SMD -0.11 (95\%CI -0.41 to 0.19]).

Comparison 3. MI versus assessment and feedback

Primary outcomes

3.1 Extent of substance use:

Short follow-up: There were seven studies, 986 participants, that compared MI with a group that was only assessed and/or received feedback with substance abuse outcomes at short follow-up . The overall effect was not significant SMD0.12 (95\%CI -0.01, 0.24). The studies were homogenous (I-squared $=0 \%$ ). Medium followup: There were two studies, 265 participants, with outcomes at medium follow-up, and the effect was significant in favour of MI SMD0.38 (95\%CI 0.10 to 0.66]). I-squared was 0\%. See (Analysis 3.1)

\section{Secondary outcomes}

One study (Bien 1993) reported retention in treatment for a comparison between MI and assessment and feedback. We were not able to compute an effect size. No studies reported readiness to change for this comparison

\section{MI versus other active intervention}

\section{Primary outcomes}

\subsection{Extent of substance use:}

There were 13 studies that compared MI with a group that received another active intervention. Post-intervention: Two studies, 185 participants, found a non-significant effect SMD-0.07 (95\%CI -0.37 to 0.23$]$ ) with an I-squared of $0 \%$. Short follow-up: 12 studies, 2137 participants, found a non-significant effect SMD 0.02 (95\%CI -0.07 to 0.12$]$ ) with an I-squared of $0 \%$. Medium follow-up: six studies, 1586 participants, showed a non-significant effect SMD-0.02 (95\%CI-0.16 to 0.13]) with an I-squared of $41 \%$. Long follow-up: Two studies, 437 participants, showed a non-significant effect SMD -0.03 (95\%CI -0.21 to 0.14$])$ with and I-squared of $0 \%$. See (Analysis 4.1)

\section{Secondary outcomes}

4.2 Readiness for change:

A meta-analysis of the two studies, 350 participants, on readiness for change showed an SMD of -0.03 with a $95 \%$ confidence interval from -0.24 to 0.18 (Analysis 4.2). The results were homogenous (I-squared: 0\%). One study (Winhusen 2008) had assessed readiness for change, but we were not able to compute an effect size. No study reported repeat convictions as an outcome.

\subsection{Retention in treatment:}

Five studies, 447 participants, reported retention in treatment ( Analysis 4.3). The effect was not significant SMD 0.01 (95\%CI 0.45 to 0.47 ). I-squared was $73 \%$.

\section{Subgroup analyses}

We did not perform any subgroup analyses because no meta-analysis was significantly heterogeneous.

\section{Sensitivity analyses}

We did not perform any sensitivity analyses because no metaanalysis was significantly heterogeneous.

\section{Grading of the evidence}

The summary of findings tables 1-4 (Summary of findings for the main comparison, Summary of findings 2, Summary of findings 3, Summary of findings 4 ) show that the evidence was mostly of low quality. A few of the comparisons were of moderate quality. The downgrading of the evidence was undertaken because of risk 
of bias in the design of the studies. The randomisation was unclear in many studies. Lack of blinding of participants, providers, and outcome assessors could have caused bias, especially for the nonphysiological outcomes. There was also some uncertainty regarding incomplete outcome reporting, selective reporting, and other possible bias. Apart from the problems with risk of bias, the consistency, precision, and directness were not downgraded. There were no large effects. Dose-response gradients or plausible confounders were not discernable. 


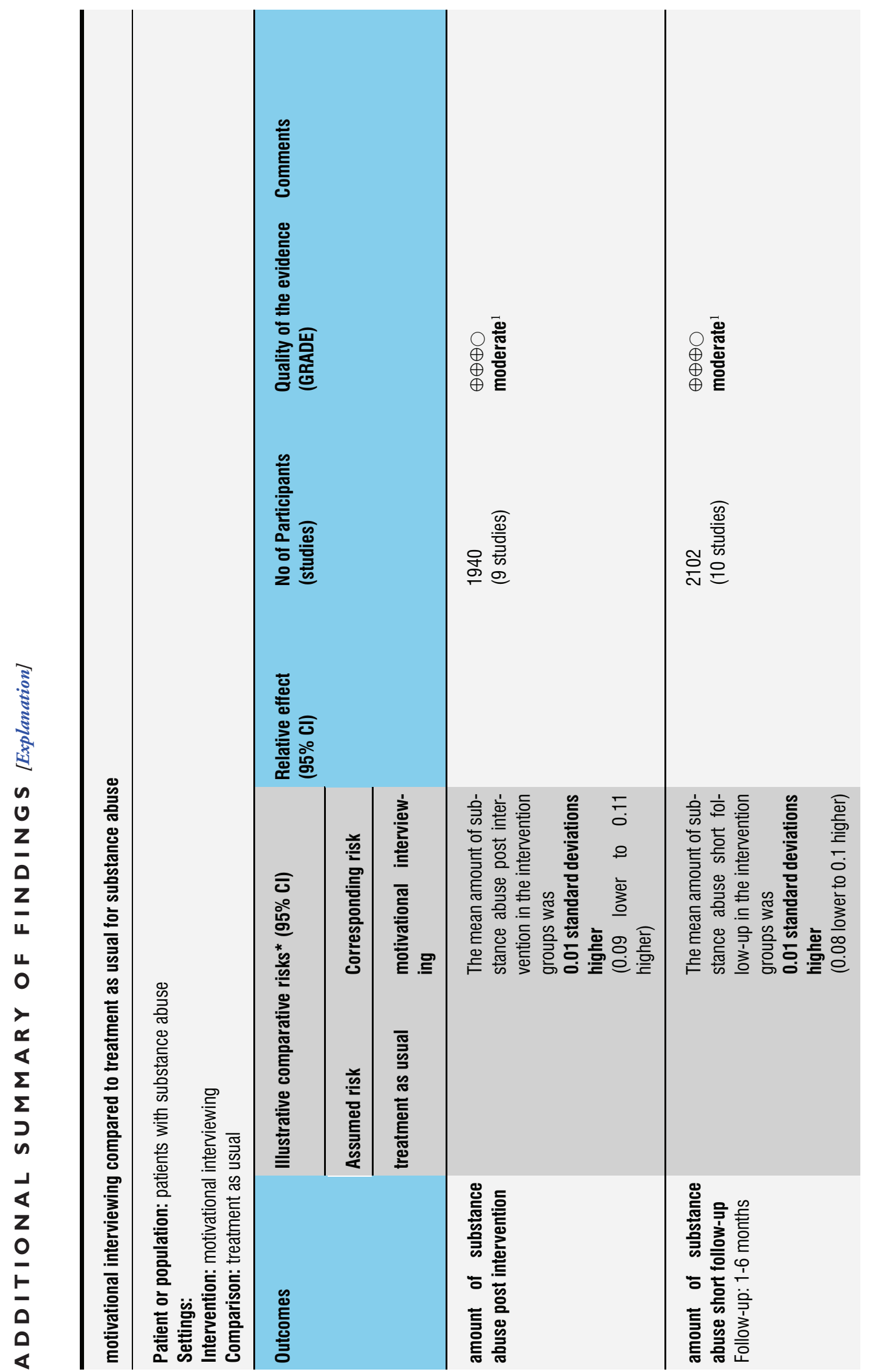

Motivational interviewing for substance abuse (Review)

Copyright (@) 20II The Cochrane Collaboration. Published by John Wiley \& Sons, Ltd. 

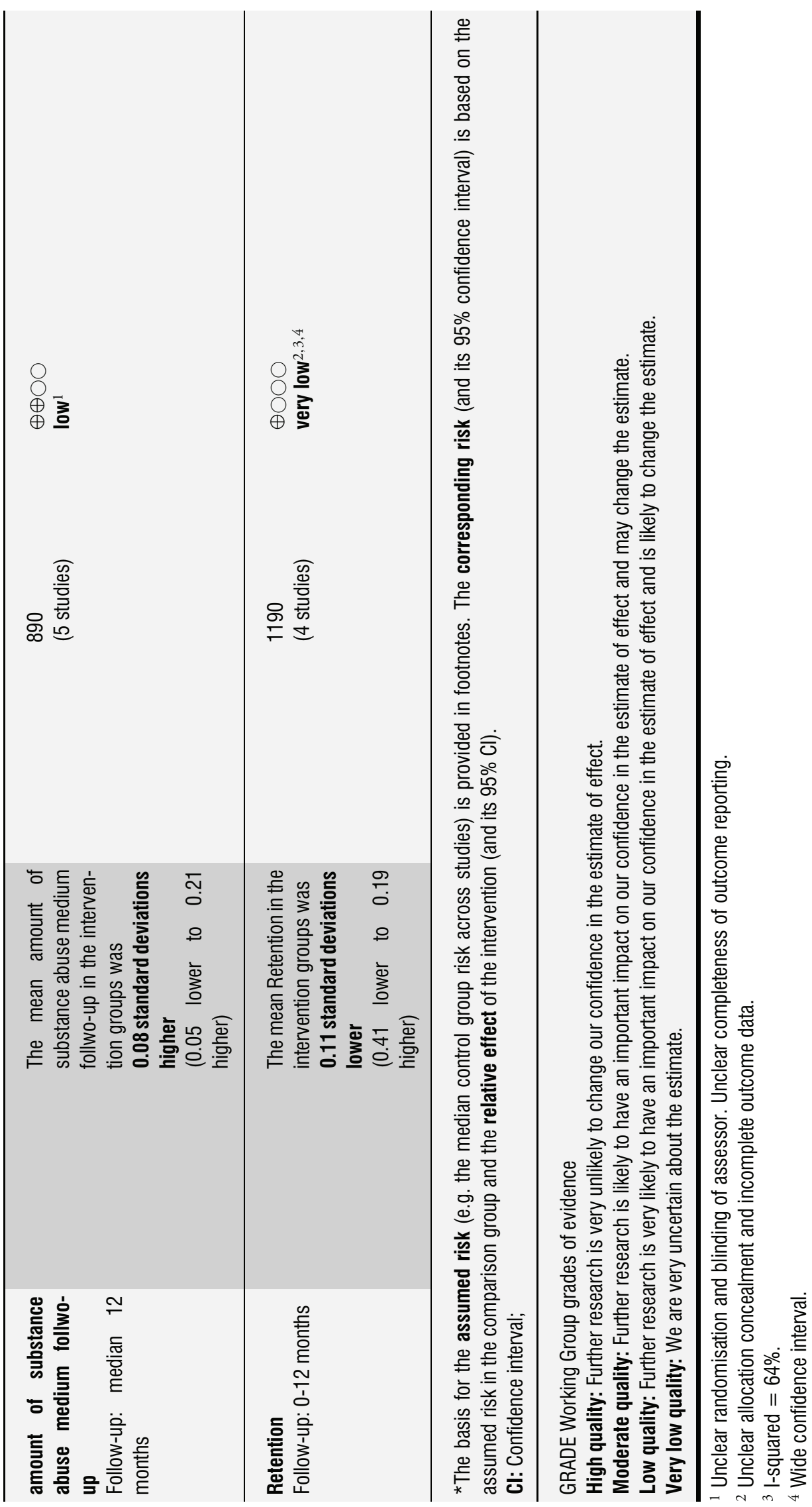

Motivational interviewing for substance abuse (Review)

Copyright (? 20II The Cochrane Collaboration. Published by John Wiley \& Sons, Ltd. 


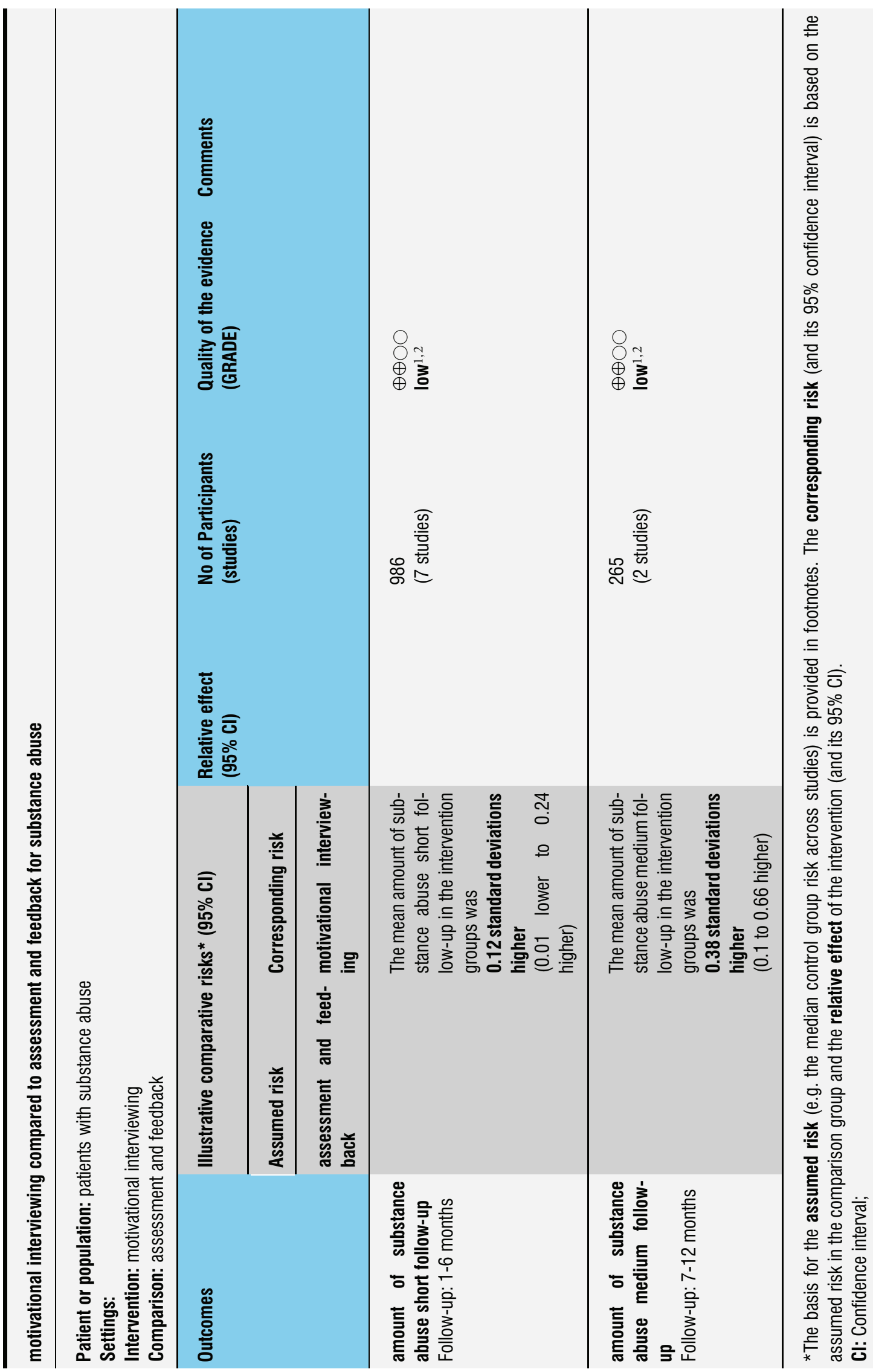

Motivational interviewing for substance abuse (Review)

Copyright (C) 20II The Cochrane Collaboration. Published by John Wiley \& Sons, Ltd. 


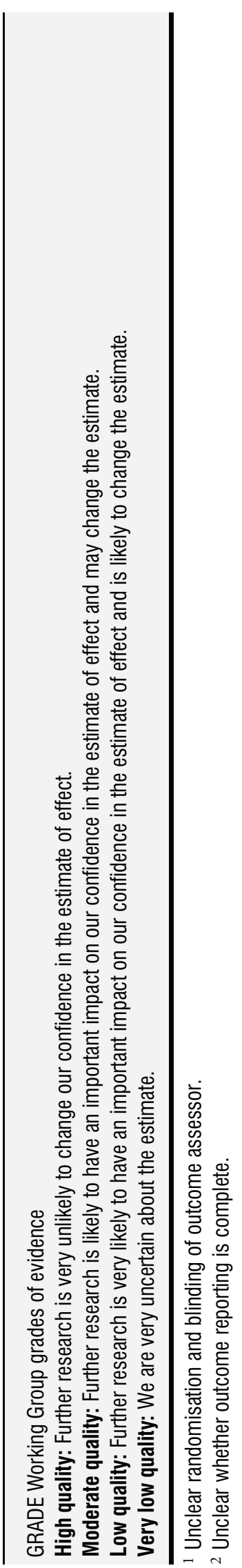




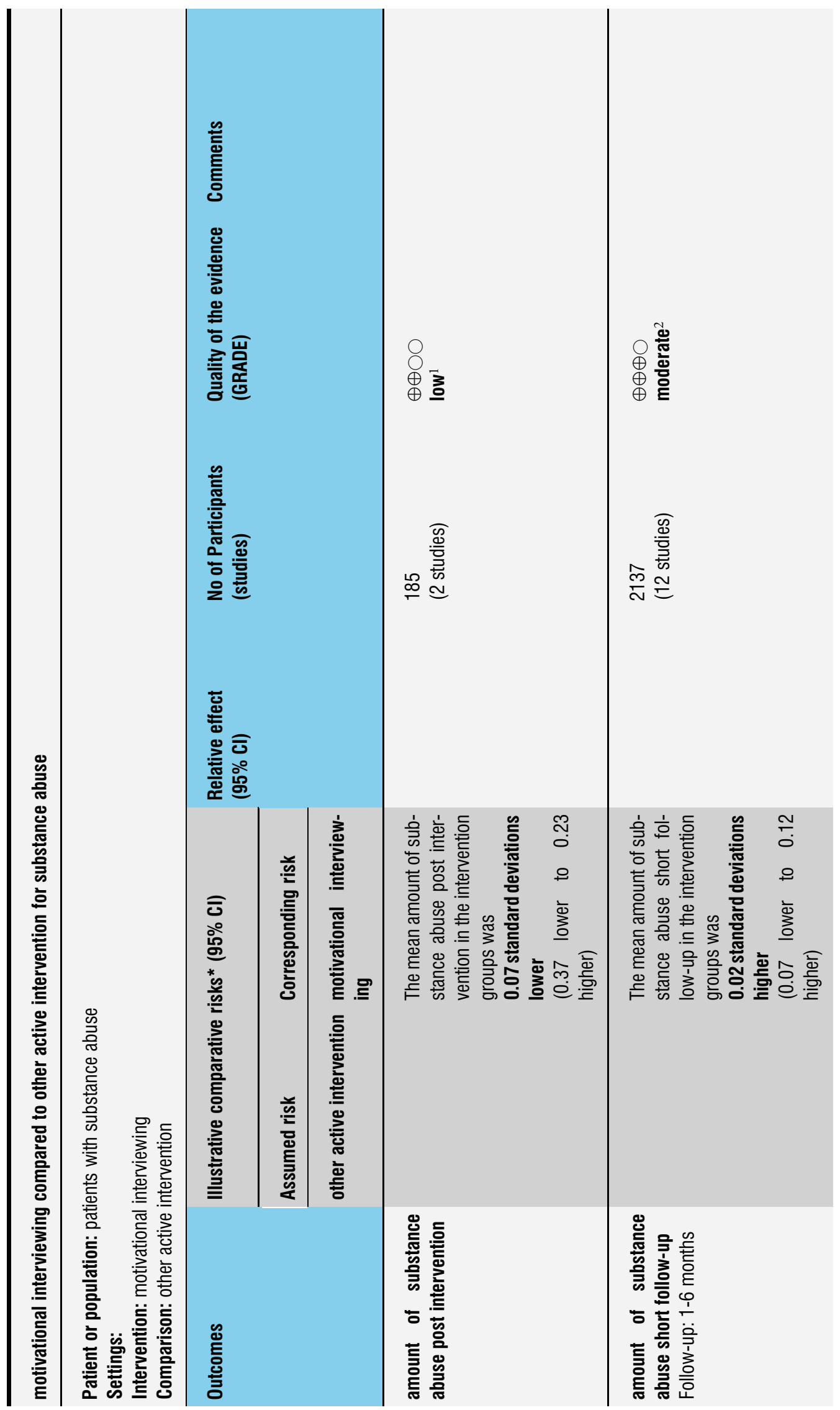

Motivational interviewing for substance abuse (Review)

Copyright (c) 201 I The Cochrane Collaboration. Published by John Wiley \& Sons, Ltd. 


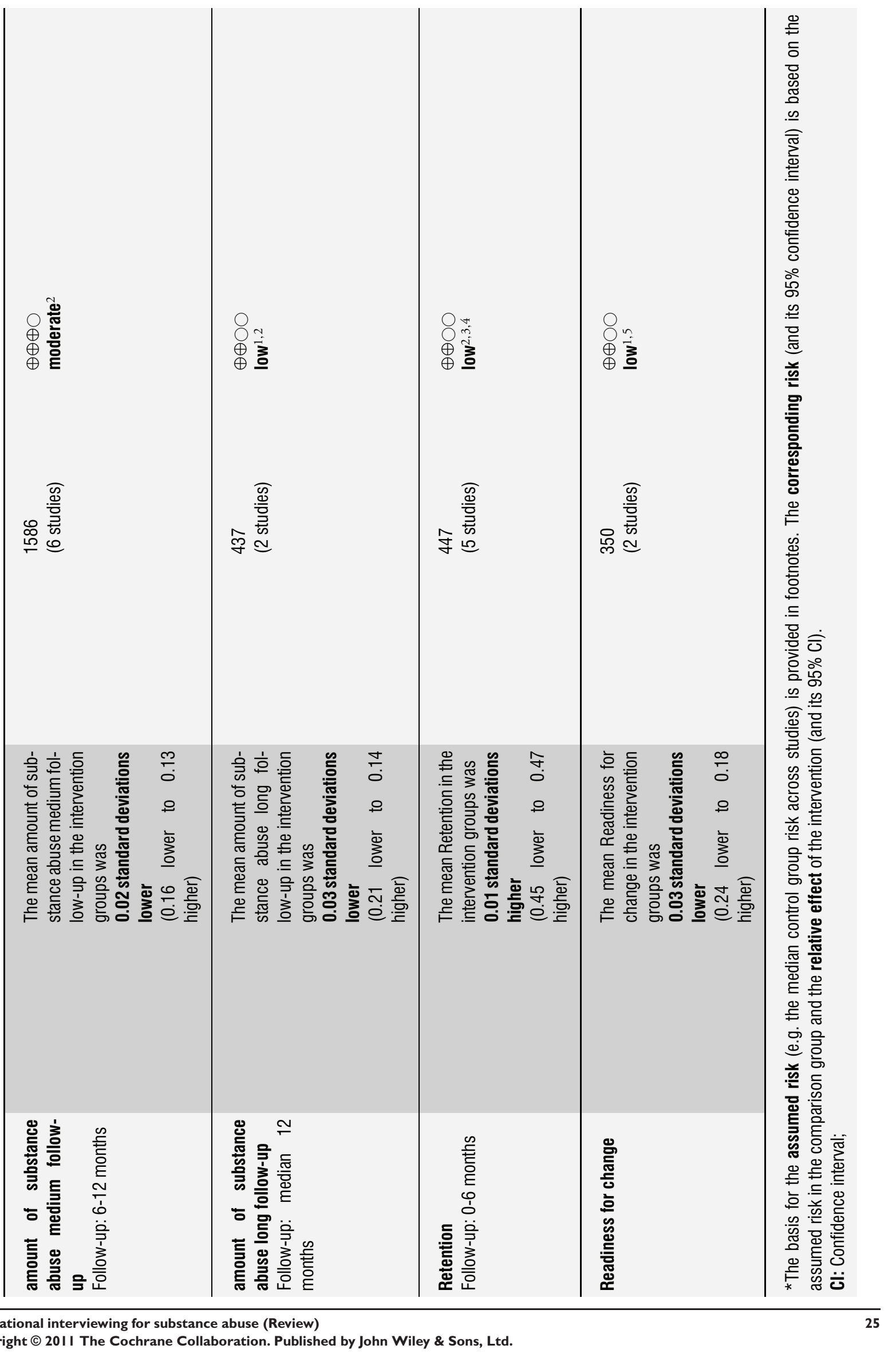




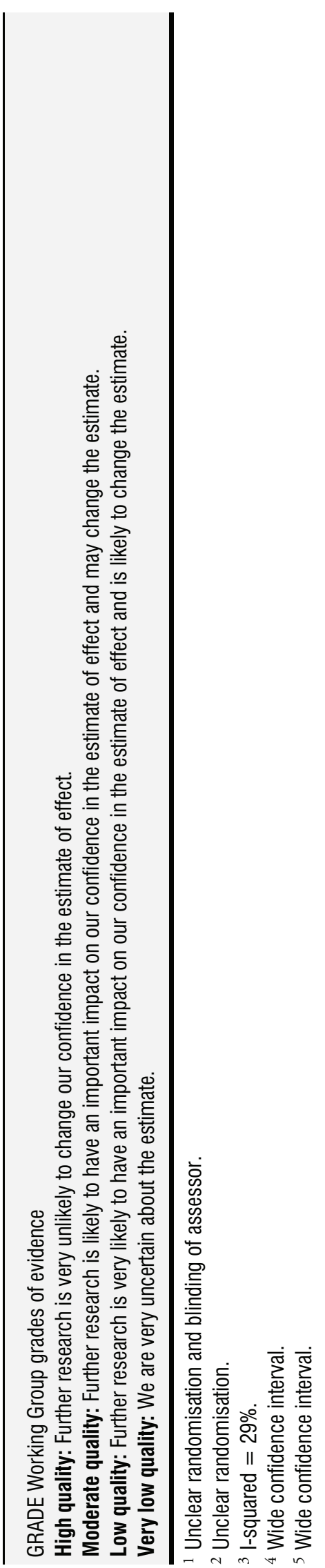




\section{DISCUSSION}

\section{Summary of main results}

\section{Extent of substance abuse}

The main finding of this review is that compared to a no treatment control MI has shown a significant effect on extent of substance abuse. The effect was strongest at post-intervention SMD 0.79 (95\%CI 0.48 to 1.09$)$ and weaker at short follow-up SMD0.17 (95\%CI 0.09 to 0.26]), and medium follow-up SMD 0.15 (95\%CI 0.04 to 0.25$]$ ). For long follow-up, the effect was not significant SMD 0.06 (95\%CI -0.16 to 0.28 ).

MI did better than assessment and feedback for medium followup regarding extent of substance abuse SMD 0.38 (95\%CI0.10, $0.66])$. For short follow-up, there was no significant effect of MI SMD 0.12 (95\% CI -0.01 to 0.24$])$. We found no data on the effect of MI vs assessment and feedback for post-treatment or for follow-up times longer than 12 months.

There was no significant difference between MI and other active intervention at any follow-up time on extent of substance abuse. Neither was there a difference between MI and treatment as usual. Type of substance and level of substance use

We were interested in studying whether MI is more effective in treating abuse of one type of substance (e. g. alcohol) versus other types of substances (e.g. cocaine), but there were not enough studies to perform such comparisons. We also wanted to summarize possibly different effects of MI on severe abuse versus less severe abuse, but we were not able to assess severity across studies from the available information reported in the included articles.

\section{Secondary outcomes}

There were not enough data to conclude about the effects of MI on retention in treatment, readiness to change, or repeat convictions.

\section{Overall completeness and applicability of evidence}

We believe that we have obtained most of the existing evidence from randomised controlled trials on the effects of motivational interviewing on substance abuse published through 2010. The research field is highly active with new randomised studies being published almost monthly. Because of this, it is difficult for this Cochrane review to be up to date all the time. The web site motivationalinterview.org is a continuous source of information about new publications, and the Motivational Interviewing Network of Trainers (MINT) is an addition to electronic literature searches. A more serious problem is that the trials mostly try to measure specific effects of MI. Among both clinicians and researchers, there seems to be a tacit overemphasis on the importance of treatment method and less focus on the impact of the individual who delivers the treatment (therapist) and who receives it (the patient). By the same token, some studies may have failed to pay sufficient attention to whether the patient and/or therapist is positive towards the treatment and whether they like and respect each other. We believe that MI certainly has large nonspecific effects, which may be much larger than the specific ones (Walach 2001).

\section{Quality of the evidence}

We strived to include only evidence from high-quality randomised controlled trials with integrity checks. Nevertheless, there are some inherent problems with research in this field. One possible source of bias is that it is impossible to blind therapists to treatment condition. And it is almost impossible to blind the patients.

\section{Potential biases in the review process}

There may not always be good correspondence between the methodological quality of a study and the quality of reporting of the study. Most scientific journals have strict word limits on articles, so authors of papers may have been unable to report important information about the study. We have applied stringent criteria when grading the evidence. Other reviewers might have reached other conclusions about the strength of evidence, but we have aimed for being explicit and transparent regarding the judgements leading to our decisions.

\section{Agreements and disagreements with other studies or reviews}

We found a moderate effect size for comparisons between MI and no intervention, while there were no differences between MI and other active treatments. This has also previously been reported by Burke (Burke 2003; Burke 2004). Similarly, our range of effect sizes are compatible with Dunn et al's (Dunn 2001) range of effect sizes. Dunn also found that most comparisons between MI and a no-treatment control favoured MI. The meta-analysis by Lundahl et al (Lundahl 2010) reported an effect size of $g=0.28$ for MI against weak comparison groups, similar to our findings. Lundahl found $\mathrm{g}=0.09$ for comparisons with other active interventions, which is also close to what we have found. In common with us, Hettema et al (Hettema 2005) reported a large variation in effect sizes across studies.

Motivational interviewing is a brief intervention. With only one to four sessions, one should not expect too much regarding changes in drug abuse outcomes. Nevertheless, results from randomised controlled trials have shown that MI compared to no intervention or minimal intervention can significantly reduce drug and alcohol consumption. When MI is compared to other interventions such as giving feedback on assessments or other types of psychotherapy, MI has not shown any superiority (or inferiority). This is probably because MI shares with these other interventions a number of nonspecific therapeutic factors such as attention and therapeutic 
alliance. These factors may have a much greater influence on outcome than the contribution made by approach-specific theory and technique; in Lambert's (Lambert 1986) review of empirical studies, common therapeutic factors accounted for 30\% of the therapeutic effect, technique 15\%, expectancy (placebo-effect) 15\% and spontaneous remission $40 \%$.

\section{A U THORS' CONCLUSIONS}

\section{Implications for practice}

Motivational interviewing is a brief intervention, typically lasting for $1-4$ sessions. If therapists are comfortable with this style of working with clients they should feel confident that providing MI will be more effective than doing nothing. But if they for instance prefer giving cognitive behavior therapy (CBT), the evidence (of low to moderate quality) is too weak to conclude that CBT will be more effective, equally effective or less effective than MI.

\section{Implications for research}

This is a field where there is no lack of randomised controlled trials. Perhaps it is time to move from only studying whether MI works to also studying how it works, that is to study the mechanisms behind MI. Apodaca and Longabaugh (Apodaca 2009) have e.g. published a review in which they collected empirical data from various parts of the causal chain in a model that they developed.

\section{ACKNOWLEDGEMENTS}

Thanks to Tom Barth, Peter Prescott, and Tore Børtveit for helpful suggestions about inclusion criteria. Thanks to Hege Sletsjøe, who performed an updated search in November 2009.

\section{RE F E R E N C E S}

\section{References to studies included in this review}

Anton 2005 \{published data only\}

* Anton RF, Moak DH, Latham P, Waid LR, Myrick H, Voronin $\mathrm{K}$, et al.Naltrexone combined with either cognitive behavioral or motivational enhancement therapy for alcohol dependence. Journal of Clinical Psychopharmacology 2005;25(4):349-57. Baros AM, Latham PK, Moak DH, Voronin K, Anton RF. What role does measuring medication compliance play in evaluating the efficacy of naltrexone?. Alcoholism: Clinical \& Experimental Research 2007;31(4):596-603.

Ball 2007a \{published data only\}

* Ball SA, Todd M, Tennen H, Armeli S, Mohr C, Affleck G, et al.Brief motivational enhancement and coping skills interventions for heavy drinking. Addictive Behaviors 2007;32(6):1105-18.

Ball 2007b \{published data only\}

* Ball SA, Martino S, Nich C, Frankforter TL, Van Horn D, CritsChristoph P, et al.Site matters: multi site randomised trial of motivational enhancement therapy in community drug abuse clinics. Journal of Consulting \& Clinical Psychology 2007;75(4): 556-67.

Barnett 2007 \{published data only\}

* Barnett NP, Murphy JG, Colby SM, Monti PM. Efficacy of counsellor vs. computer-delivered intervention with mandated college students.. Addictive Behaviors 2007;32(11):2529-48.

\section{Bazargan-Hejazi 2005 \{published data only\}}

* Bazargan-Hejazi S, Bing E, Bazargan M, Der-Martirosian C, Hardin E, Bernstein J, et al.Evaluation of a brief intervention in an inner-city emergency department.. Annals of Emergency Medicine 2005;46(1):67-76.
Bell 2007 \{published data only\}

* Bell JB. Volitional control, self-regulation, and motivational interviewing in veterans with alcohol problems. Dissertation Abstracts International: Section B: The Sciences and Engineering 2007; Vol. 68, issue 7-B:2008pp-B.

Bernstein 2009 \{published data only\}

* Bernstein E, Edwards E, Dorfman D, Heeren T, Bliss C,

Bernstein J. Screening and brief intervention to reduce marijuana use among youth and young adults in a paediatric emergency department.. Academic Emergency Medicine 2009;16(11):1174-85.

Bien 1993 \{published data only\}

* Bien TH, Miller WR, Boroughs JM. Motivational interviewing with alcohol outpatients. Behavioural Psychotherapy 1993;21(4): $347-56$.

Borsari 2005 \{published data only\}

* Borsari B, Carey KB. Two brief alcohol interventions for mandated college students. Psychology of Addictive Behaviors 2005; 19(3):296-302.

Brown 2010 \{published data only\}

* Brown TG, Dongier M, Ouimet MC, Tremblay J, Chanut F, Legault L, et al.Brief motivational interviewing for DWI recidivists who abuse alcohol and are not participating in DWI intervention: a randomised controlled trial. Alcoholism: Clinical and Experimental Research 2010;34(2):1-10.

Carey 2006 \{published data only\}

* Carey KB, Carey MP, Maisto SA, Henson JM. Brief motivational interventions for heavy college drinkers: A randomised controlled trial. Journal of Consulting and Clinical Psychology 2006;74(5): $943-54$.

Carroll 2006a \{published data only\} * Carroll KM, Ball SA, Nich C, Martino S, Frankforter TL, Farentinos C, et al.Motivational interviewing to improve treatment 
engagement and outcome in individuals seeking treatment for substance abuse: a multisite effectiveness study. Drug and Alcohol Dependence 2006;81(3):301-12

\section{Carroll 2006b \{published data only\}}

* Carroll KM, Easton CJ, Nich C, Hunkele KA, Neavins TM, Sinha R, et al.The use of contingency management and motivational/skills-building therapy to treat young adults with marijuana dependence. Journal of Consulting and Clinical Psychology 2006;74(5):955-66.

Olmstead TA, Sindelar JL, Easton CJ, Carroll KM. The costeffectiveness of four treatments for marijuana dependence. Addiction 2007;102(9):1443-53.

\section{Carroll 2009 \{published data only\}}

* Carroll KM, Martino S, Ball SA, Nich C, Frankforter T, Anez LM, Paris M, Suarez-Morales L, Szapocznik J, Miller WR, Rosa C, Matthews J, Farentinos C. A multi site randomised effectiveness trial of motivational enhancement therapy for Spanish-speaking substance users. Journal of Consulting and Clinical Psychology 2009; 77(5):993-9.

Chanut 2007 \{published data only\}

* Chanut F, Dongier M, Legault L, Tremblay J, Nadeau L, Ouimet $\mathrm{MC}$, et al.Pilot study of motivational interviewing among persons convicted of driving under the influence. Drogues, sante et societe 2007;6(2):83-115.

\section{Connors 2002 \{published data only\}}

* Connors GJ, Walitzer KS, Dermen KH. Preparing clients for alcoholism treatment: effects on treatment participation and outcomes. Journal of Consulting and Clinical Psychology 2002;70(5): 1161-9.

\section{Copeland 2001 \{published data only\}}

* Copeland J, Swift W, Rees V. Clinical profile of participants in a brief intervention program for cannabis use disorder. Journal of Substance Abuse Treatment 2001;20:45-52.

Copeland J, Swift W, Roffman R, Stephens R. A randomised controlled trial of brief cognitive-behavioral interventions for cannabis use disorder. Journal of Substance Abuse Treatment 2001; 21:55-64.

\section{D'Amico 2008 \{published data only\}}

* D’Amico EJ, Miles JN, Stern SA, Meredith LS. Brief motivational interviewing for teens at risk of substance use consequences: a randomised pilot study in a primary care clinic. Journal of Substance Abuse Treatment 2008;35(1):53-61.

Stern SA, Meredith LS, Gholson J, Gore P, D'Amico EJ. Project CHAT: a brief motivational substance abuse intervention for teens in primary care. Journal of Substance Abuse Treatment 2007;32: 153-65.

De Wildt 2002 \{published data only\}

* De Wildt WA, Schippers GM, van den Brink W, Potgieter AS, Deckers F, Bets D. Does psychosocial treatment enhance the efficacy of Acamprosate in patients with alcohol problems?. Alcohol and alcoholism (Oxford, Oxfordshire) 2002;37(4):375-382.

Emmen 2005 \{published data only\}

* Emmen MJ, Schippers GM, Wollersheim H, Bleijenberg G. Adding psychologist's intervention to physicians' advice to problem drinkers in the outpatient clinic. Alcohol and Alcoholism 2005;40 (3):219-26.
Feldstein 2007 \{published data only\}

* Feldstein SW, Forcehimes AA. Motivational interviewing with underage college drinkers: a preliminary look at the role of empathy and alliance. American Journal of Drug and Alcohol Abuse 2007;33(5):737-46.

Freyer-Adam 2008 \{published data only\}

* Freyer-Adam J, Coder B, Baumeister SE, Bischof G, Riedel J, Paatsch K, et al.Brief alcohol intervention for general hospital inpatients: A randomised controlled trial. Drug and Alcohol Dependence 2008;93(3):233-43.

Kadden 2007 \{published data only\}

* Kadden RM, Litt MD, Kabela-Cormier E, Petry NM. Abstinence rates following behavioral treatments for marijuana dependence. Addictive Behaviors 2007;32(6):1220-36.

Litt MD, Kadden RM, Kabela-Cormier E, Petry NM. Coping skills training and contingency management treatments for marijuana dependence: exploring mechanisms of behavior change. Addiction 2008;103(4):638-48.

Kahler 2004 \{published data only\}

* Kahler CW, Read JP, Ramsey SE, Stuart GL, McCrady BS, Brown RA. Motivational enhancement for 12-step involvement among patients undergoing alcohol detoxification. Journal of Consulting and Clinical Psychology 2004;72(4):736-41.

Kavanagh 2004 \{published data only\}

* Kavanagh DJ, Young R, White A, Saunders JB, Wallis J, Shockley $\mathrm{N}$, Jenner $\mathrm{L}$, et al.A brief motivational intervention for substance misuse in recent-onset psychosis. Drug and Alcohol Review 2004;23 (2):151-5.

Kay-Lambkin 2009 \{published data only\} Baker A, Turner A, Kay-Lambkin FJ, Lewin TJ. The long and the short of treatments for alcohol and cannabis misuse among people with severe mental disorders. Addictive Behaviors 2009;34:852-8. * Kay-Lambkin FJ, Baker AL, Lewin TJ, Carr VJ. Computer-based psychological treatment for comorbid depression and problematic alcohol and/or cannabis use: a randomized controlled trial of clinical efficacy. Addiction 2009;104:378-88.

Kelly 2000 \{published data only\}

* Kelly AB, Halford WK, Young RM. Maritally distressed women with alcohol problems: the impact of a short-term alcohol-focused intervention on drinking behaviour and marital satisfaction. Addiction 2000;95(10):1537-49.

Maisto 2001 \{published data only\} Gordon AJ, Conigliaro J, Maisto SA, McNeil M, Kraemer KL, Kelley ME. Comparison of consumption effects of brief interventions for hazardous drinking elderly. Substance Use and Misuse 2003;38(8):1017-35.

* Maisto SA, Conigliaro J, McNeil M, Kraemer K, Conigliaro RL, Kelley ME. Effects of two types of brief intervention and readiness to change on alcohol use in hazardous drinkers. Journal of Studies on Alcohol 2001;62(5):605-14.

MarijuanaTP 2004 \{published data only\} Litt MD, Kadden RM, Stephens RS, Marijuana Treatment Project Research Group. Coping and self-efficacy in marijuana treatment: 
results from the marijuana treatment project. Journal of Consulting and Clinical Psychology 2005;73(6):1015-25.

* The Marijuana Treatment Project Research Group. Brief treatments for cannabis dependence: findings from a randomised multi site trial. Journal of Consulting and Clinical Psychology 2004; 72(3):455-66.

Marsden 2006 \{published data only\}

* Marsden J, Stillwell G, Barlow H, Boys A, Taylor C, Hunt N, et al.An evaluation of a brief motivational intervention among young ecstasy and cocaine users: no effect on substance and alcohol use outcomes. Addiction 2006;101(7):1014-26.

Martin 2008 \{published data only\}

* Martin G, Copeland J. The adolescent cannabis check-up: Randomized trial of a brief intervention for young cannabis users. Journal of Substance Abuse Treatment 2008;34(4):407-14.

Martino 2006 \{published data only\}

* Martino S, Carroll KM, Nich C, Rounsaville BJ. A randomised controlled pilot study of motivational interviewing for patients with psychotic and drug use disorders. Addiction 2006;101(10): 1479-92.

Mastroleo 2010 \{published data only\}

* Mastroleo NR, Turrisi R, Carney JV, Ray AE, Larimer ME. Examination of post training supervision of peer counsellors in a motivational enhancement intervention to reduce drinking in a sample of heavy-drinking college students. Journal of Substance Abuse Treatment 2010;39:289-97.

MATCH 1993 \{published data only\}

Bauer LO, Covault J, Harel O, Das S, Gelernter J, Anton R, Kranzler HR. Variation in GABRA2 predicts drinking behavior in project MATCH subjects. Alcoholism, Clinical and Experimental Research 2007;31(11):1780-7.

Carroll KM, Connors GJ, Cooney NL, DiClemente CC, Donovan DM, Kadden RR, et al.Internal validity of Project MATCH treatments: discriminability and integrity. Journal of Consulting and Clinical Psychology 1998;66(2):290-303.

Longabaugh R, Wirtz PW, Zweben A, Stout RL. Network support for drinking, Alcoholics Anonymous and long-term matching effects. Addiction 1998;93(9):1313-33.

Project Match Research Group. Therapist effects in three treatments for alcohol problems. Psychotherapy Research 1998;8(4): 455-74.

Project MATCH Research Group. Matching Alcoholism Treatments to Client Heterogeneity: Project MATCH posttreatment drinking outcomes. Journal of Studies on Alcohol 1997;58(1):7-29.

Project MATCH Research Group. Matching alcoholism treatments to client heterogeneity: Project MATCH three-year drinking outcomes. Alcoholism: Clinical and Experimental Research 1998;22 (6):1300-11.

Project MATCH Research Group. Matching alcoholism treatments to client heterogeneity: treatment main effects and matching effects on drinking during treatment. Project MATCH Research Group. Journal of Studies on Alcohol 1998;59(6):631-9.

Project MATCH Research Group. Matching patients with alcohol disorders to treatments: clinical implications from Project MATCH. Journal of Mental Health 1998;7(6):589-602. * Project MATCH Research Group. Project MATCH (Matching
Alcoholism Treatment to Client Heterogeneity): rationale and methods for a multisite clinical trial matching patients to alcoholism treatment. Alcoholism: Clinical and Experimental Research 1993;17(6):1130-45.

Project MATCH Research Group. Project MATCH secondary a priori hypotheses. Project MATCH Research Group. Addiction 1997;92(12):1671-98.

Thevos AK, Thomas SE, Randall CL. Social support in alcohol dependence and social phobia: Treatment comparisons. Research on Social Work Practice 2001;11(4):458-72.

Tonigan JS, Miller WR, Juarez P, Villanueva M. Utilization of AA by Hispanic and non-Hispanic white clients receiving outpatient alcohol treatment. Journal of Studies on Alcohol 2002;63(2):215-8. Villanueva M, Tonigan JS, Miller WR. Response of Native American clients to three treatment methods for alcohol dependence. Journal of ethnicity in substance abuse 2007;6(2):41-8. Wu J, Witkiewitz K. Network support for drinking: An application of multiple groups growth mixture modelling to examine clienttreatment matching. Journal of Studies on Alcohol and Drugs 2008; 69(1):21-9.

Zywiak WH, Longabaugh R, Wirtz PW. Decomposing the relationships between pretreatment social network characteristics and alcohol treatment outcome. Journal of Studies on Alcohol 2002; 63(1):114-21.

McCambridge 2008 \{published data only\}

* McCambridge J, Slym RL, Strang J. Randomized controlled trial of motivational interviewing compared with drug information and advice for early intervention among young cannabis users. Addiction 2008;103(11):1809-18.

Miller 2003 \{published data only\}

* Miller WR, Yahne CE, Tonigan JS. Motivational interviewing in drug abuse services: a randomised trial. Journal of Consulting and Clinical Psychology 2003;71(4):754-63.

\section{Morgenstern 2009 \{published data only\}}

* Morgenstern J, Bux DA, Parsons J, Hagman BT, Wainberg M, Irwin T. Randomized trial to reduce club drug use and HIV risk behaviours among men who have sex with men. Journal of Consulting and Clinical Psychology 2009;77(4):645-56.

Naar-King 2007 \{published data only\}

Naar-King S, Lam P, Wang B, Wright K, Parsons JT, Frey MA. Brief report: maintenance of effects of motivational enhancement therapy to improve risk behaviours and HIV-related Health in a randomised controlled trial of youth living with HIV. Journal of Pediatric Psychology 2008;33(4):441-5.

Naar-King S, Wright K, Parsons J, Frey M, Templin T, \& Ondersma S. Transtheoretical model and substance use in HIV+ youth. AIDS Care 2006;18(7):839-845.

Naar-King S, Wright K, Parsons J, Frey M, Templin T, Ondersma S. Transtheoretical model and condom use in HIV+ youth. Health Psychology 2006;25(5):648-52.

* Naar-King S, Wright K, Parsons JT, Frey M, Templin T, Lam P, et al.Healthy Choices: Motivational enhancement therapy for health risk behaviours in HIV-positive youth. AIDS Education and Prevention 2006;18(1):1-11.

\section{Parsons 2009 \{published data only\}}

* Parsons JT, Golub SA, Rosof E, Holder C. Motivational interviewing and cognitive-behavioral intervention to improve HIV 
medication adherence among hazardous drinkers: a randomized controlled trial. Journal of Acquired Immune Deficiency Syndromes 2007;46(4):443-50.

\section{Peterson 2006 \{published data only\}}

* Peterson PL, Baer JS, Wells EA, Ginzler JA, Garrett SB. Shortterm effects of a brief motivational intervention to reduce alcohol and drug risk among homeless adolescents. Psychology of Addictive Behaviors 2006;20(3):254-64.

Rohsenow 2004 \{published data only\}

* Rohsenow DJ, Monti PM, Martin RA, Colby SM, Myers MG, Gulliver SB, et al.Motivational enhancement and coping skills training for cocaine abusers: effects on substance use outcomes. Addiction 2004;99(7):862-74

Saitz 2007 \{published data only\}

* Saitz R, Palfai TP, Cheng DM, Horton NJ, Freedner N, Dukes K, et al.Brief intervention for medical inpatients with unhealthy alcohol use: a randomised, controlled trial. Annals of Internal Medicine 2007;146(3):167-76.

Schaus 2009 \{published data only\}

* Schaus JF, Sole ML, Mccoy TP, Mullett N, O’Brien MC. Alcohol screening and brief intervention in a college student health centre: a randomised controlled trial. Journal of Studies on Alcohol and Drugs 2009; Supplement 16:131-41.

Sellman 2001 \{published data only\}

Adamson SJ, Sellman JD. Five-year outcomes of alcohol-dependent persons treated with motivational enhancement. Journal of Studies on Alcohol and Drugs 2008;69(4):589-93.

* Sellman JD, Sullivan PF, Dore GM, Adamson SJ, MacEwan I. A randomised controlled trial of motivational enhancement therapy (MET) for mild to moderate alcohol dependence. Journal of Studies on Alcohol 2001;62(3):389-96.

Stein 2002 \{published data only\}

* Stein MD, Charuvastra A, Maksad J, Anderson BJ. A randomised trial of a brief alcohol intervention for needle exchangers (BRAINE). Addiction 2002;97(6):691-700.

Stein 2009 \{published data only\}

* Stein MD, Herman DS, Anderson BJ. A motivational intervention trial to reduce cocaine use. Journal of Substance Abuse Treatment 2009;36(1):118-25.

Stein 2010 \{published data only\}

Hebert MR, Clarke JG, Caviness CM, Ray MK, Friedmann PD, Stein MD. Feasibility of gaining access to women in jail for interventions. Women Health 2008;47:79-93.

* Stein MD, Caviness CM, Anderson BJ, Hebert M, Clarke JG. A brief alcohol intervention for hazardously drinking incarcerated women. Addiction 2010;105:466-75.

Stephens 2007 \{published data only\}

* Stephens RS, Roffman RA, Fearer SA, Williams C, Burke RS The Marijuana Check-up: promoting change in ambivalent marijuana users. Addiction 2007;102(6):947-57.

Stotts 2001 \{published data only\}

Stotts A, Schmitz J, Sayre S, Schwebel A, Grabowski J. Brief motivational enhancement therapy prior to relapse prevention for cocaine dependent patients. 61th Annual Scientific Meeting of the
College on Problems of Drug Dependence 1999; The Cochrane Central Register of Controlled Trials (CENTRAL) Issue 2.:218. Stotts AL, Schmitz JM, Bordnick PS, Schwebel AK. An outpatient cocaine detoxification program using motivational enhancement therapy. NIDA Research Monograph. 1997;178:98.

* Stotts AL, Schmitz JM, Rhoades HM, Grabowski J. Motivational interviewing with cocaine-dependent patients: a pilot study. Journal of Consulting and Clinical Psychology 2001;69(5):858-62.

\section{Stotts 2006 \{published data only\}}

* Stotts AL, Potts GF, Ingersoll G, George MR, Martin LE. Preliminary feasibility and efficacy of a brief motivational intervention with psychophysiological feedback for cocaine abuse. Substance Abuse 2006;27(4):9-20.

Thush 2009 \{published data only\}

* Thush C, Wiers RW, Moerbeek M, Ames SL, Grenard JL, Sussman S, et al.Influence of motivational interviewing on explicit and implicit alcohol-related cognition and alcohol use in at-risk adolescents. Psychology of Addictive Behaviors 2009;23(1):146-51.

\section{UKATT 2005 \{published data only\}}

Orford J, Hodgson R, Copello A, Krishnan M, de Madariaga M, Coulton S. Treatment: What was useful about that session? Clients' and therapists' comments after sessions in the UK alcohol treatment trial (UKATT). Alcohol and Alcoholism 2009;44(3):306-13.

Orford J, Hodgson R, Copello A, Wilton S, Slegg G. To what factors do clients attribute change? Content analysis of follow-up interviews with clients of the UK Alcohol Treatment Trial. Journal of Substance Abuse Treatment 2009;36(1):49-58.

UKATT Research Team. Cost effectiveness of treatment for alcohol problems: findings of the randomised UK alcohol treatment trial (UKATT). BMJ 2005;331(7516):544.

* UKATT Research Team. Effectiveness of treatment for alcohol problems: findings of the randomised UK alcohol treatment trial (UKATT). BMJ 2005;331(7516):541.

UKATT Research Team. UK Alcohol Treatment Trial: clienttreatment matching effects. Addiction 2008;103(2):228-38.

Walitzer 2008 \{published data only\}

* Walitzer KS, Dermen KH, Barrick C. Facilitating involvement in Alcoholics Anonymous during out-patient treatment: a randomised clinical trial. Addiction 2009;104(3):391-401.

Walker 2006 \{published data only\}

* Walker DD, Roffman RA, Stephens RS, Wakana K, Berghuis J, Kim W. Motivational enhancement therapy for adolescent marijuana users: a preliminary randomised controlled trial. Journal of Consulting and Clinical Psychology 2006;74(3):628-32.

Walters 2009 \{published data only\}

* Walters ST, Vader AM, Harris TR, Field CA, Jouriles EN. Dismantling motivational interviewing and feedback for college drinkers: a randomised clinical trial. Journal of Consulting and Clinical Psychology 2009;77(1):64-73.

White 2006 \{published data only\}

Mun EY, White HR, Morgan TJ. Individual and situational factors that influence the efficacy of personalized feedback substance use interventions for mandated college students. Journal of Consulting and Clinical Psychology 2009;77(1):88-102.

* White HR, Morgan TJ, Pugh LA, Celinska K, Labouvie EW, Pandina RJ. Evaluating two brief substance-use interventions for 
mandated college students. Journal of Studies on Alcohol 2006;67: 309-17.

White HR, Mun EY, Pugh L, Morgan TJ. Long-term effects of brief substance use interventions for mandated college students: sleeper effects of an in-person personal feedback intervention. Alcoholism, clinical and experimental research 2007;31(8):1380-91.

Winhusen 2008 \{published data only\}

Ondersma SJ, Winhusen T, Erickson SJ, Stine SM, Wang Y. Motivation enhancement therapy with pregnant substance-abusing women: Does baseline motivation moderate efficacy?. Drug and Alcohol Dependence 2009;101(1-2):74-9.

* Winhusen T, Kropp F, Babcock D, Hague D, Erickson SJ, Renz $\mathrm{C}$, et al.Motivational enhancement therapy to improve treatment utilization and outcome in pregnant substance users. Journal of Substance Abuse Treatment 2008;35:161-73.

Winters 2007 \{published data only\}

* Winters KC, Leitten W. Brief intervention for drug-abusing adolescents in a school setting. Psychology of Addictive Behaviors 2007;21(2):249-54.

\section{Wood 2007 \{published data only\}}

Capone C, Wood MD. Thinking about drinking: Need for cognition and readiness to change moderate the effects of brief alcohol interventions. Psychology of Addictive Behaviors 2009;23(4): 684-8.

* Wood MD, Capone C, Laforge R, Erickson DJ, Brand NH. Brief motivational intervention and alcohol expectancy challenge with heavy drinking college students: A randomised factorial study. Addictive Behaviors 2007;32(11):2509-28.

\section{References to studies excluded from this review}

Adamson 2001 \{published data only\}

* Adamson SJ, Selman JD. Drinking goal selection and treatment outcome in outpatients with mild-moderate alcohol dependence. Drug and Alcohol Review 2001;20:351-9.

Allsop 1997 \{published data only\}

* Allsop S, Saunders B, Phillips M, Carr A. A trial of relapse prevention with severely dependent male problem drinkers. Addiction 1997;92(1):61-73.

Anderson 1992 \{published data only\}

* Anderson P, Scott E. The effect of general practitioners' advice to heavy drinking men. British Journal of Addiction 1992;87:891-900.

Aubrey 1998 \{published data only\}

* Aubrey Lauren Lawendowski. Motivational interviewing with adolescents presenting for outpatient substance abuse treatment. Dissertation Abstracts International: Section B: The Sciences and Engineering 1998; Vol. 59, issue 3-B:Sep-B.

Baer 2001 \{published data only\}

* Baer JS, Kivlahan DR, Blume AW, McKnight P, Marlatt GA. Brief intervention for heavy-drinking college students: 4-year follow-up and natural history. American Journal of Public Health 2001;91(8):1310-6.

Baker 1993 \{published data only\}

* Baker A, Heather N, Wodak A, Dixon J, Holt P. Evaluation of a cognitive-behavioural intervention for HIV prevention among injecting drug users. AIDS 1993;7(2):247-56.

\section{Baker 2001 \{published data only\}}

Baker A, Boggs T, Lewin T. Characteristics of regular amphetamine users and implications for treatment. Drug and Alcohol Review 2001;20:49-56.

* Baker A, Boggs TG, Lewin TJ. Randomized controlled trial of brief cognitive-behavioural interventions among regular users of amphetamine. Addiction 2001;96(9):1279-87.

Baker A, Lee NK, Claire M, Lewin TJ, Grant T, Pohlman S, et al.Drug use patterns and mental health of regular amphetamine users during a reported 'heroin drought'. Addiction 2004;99: 875-84.

Baker 2002 \{published data only\}

* Baker A, Lewin T, Reichler H, Clancy R, Carr V, Garrett R, et al.Evaluation of a motivational interview for substance use within psychiatric in-patient services. Addiction 2002;97(10):1329-37.

Baker 2002b \{published data only\}

* Baker A, Lewin T, Reichler H, Clancy R, Carr V, Garrett R, et al.Motivational interviewing among psychiatric in-patients with substance use disorders. Acta Psychiatrica Scandinavica 2002;106 (3):233-40.

Baker 2005 \{published data only\}

* Baker A, Lee NK, Claire M, Lewin TJ, Grant T, Pohlman S, et al.Brief cognitive behavioural interventions for regular amphetamine users: a step in the right direction. Addiction 2005; 100(3):367-78.

Baker 2006 \{published data only\}

* Baker A, Bucci S, Lewin TJ, Kay-Lambkin F, Constable PM, Carr VJ. Cognitive-behavioural therapy for substance use disorders in people with psychotic disorders: Randomised controlled trial. British Journal of Psychiatry 2006;188:439-48.

Barrowclough 2000 \{published data only\}

* Barrowclough C, Haddock G, Tarrier N, Moring J, Lewis S. Cognitive behavioral intervention for individuals with severe mental illness who have a substance misuse problem. Psychiatric Rehabilitation Skills 2000;4(2):216-33.

Barrowclough 2001 \{published data only\}

* Barrowclough C, Haddock G, Tarrier N, Lewis SW, Moring J, O'Brien R, et al.Randomized controlled trial of motivational interviewing, cognitive behavior therapy, and family intervention for patients with comorbid schizophrenia and substance use disorders. American Journal of Psychiatry 2001;158(10):1706-13.

Becka 2004 \{published data only\}

* Becka J. Efficacy of cognitive behavioral methods in decreasing drug use by methadone clinic patients compared with standard conditions. Ceska a Slovenska Psychiatrie 2004;SUPPL. 1:4-7.

Beckham 2007 \{published data only\}

* Beckham N. Motivational interview with hazardous drinkers. Journal of the American Academy of Nurse Practitioners 2007;19(2): 103-10.

Bellack 2006 \{published data only\}

* Bellack AS, Bennett ME, Gearon JS, Brown CH, Yang Y. A randomised clinical trial of a new behavioral treatment for drug abuse in people with severe and persistent mental illness. Archives of General Psychiatry 2006;63(4):426-32. 
Bernstein 2005 \{published data only\}

* Bernstein J, Bernstein E, Tassiopoulos K, Heeren T, Levenson S, Hingson R. Brief motivational intervention at a clinic visit reduces cocaine and heroin use. Drug and Alcohol Dependence 2005;77(1): 49-59.

Bethea 2006 \{unpublished data only\}

* Bethea A, Acosta M, Haller DL. Role of the therapeutic alliance in the treatment of pain patients who abuse prescription opioids. CPDD - 2006 Scottsdale, Arizona. 2006:\# 59.

Booth 1998 \{published data only\}

* Booth RE, Kwiatkowski C, Iguchi MY, Pinto F, John D.

Facilitating treatment entry among out-of-treatment injection drug users. Public Health Reports 1998;113 Suppl 1:116-128.

Borsari 2000 \{published data only\}

* Borsari B, Carey KB. Effects of a brief motivational intervention with college student drinkers. Journal of Consulting and Clinical Psychology 2000;68(4):728-33.

Borsari 2003 \{published data only\}

* Borsari BE. Two brief alcohol interventions for referred college students. Dissertation Abstracts International: Section B: The Sciences and Engineering 2003; Vol. 64, issue 2-B:2003, pp-B.

Brown 1993 \{published data only\}

* Brown JM, Miller WR. Impact of motivational interviewing on participation in residential alcoholism treatment. Psychology of Addictive Behaviors 1993;7:211-8.

Brown 2007 \{published data only\}

* Brown RL, Saunders LA, Bobula JA, Mundt MP, Koch PE. Randomized-controlled trial of a telephone and mail intervention for alcohol use disorders: three-month drinking outcomes. Alcoholism: Clinical and Experimental Research 2007;31(8):1372-9.

Brown 2009 \{published data only\}

* Brown RA, Strong DR, Abrantes AM, Myers MG, Ramsey SE, Kahler CW. Effects on substance use outcomes in adolescents receiving motivational interviewing for smoking cessation during psychiatric hospitalisation. Addictive Behaviors 2009;34(10): $887-91$.

Butler 2009 \{published data only\}

* Butler LH, Correia CJ. Brief alcohol intervention with college student drinkers: face-to-face versus computerized feedback. Psychology of Addictive Behaviors 2009;23(1):163-7.

Bux 2005 \{published data only\}

* Bux DA Jr, Morgenstern J, Labouvie E, Morgan T, Blanchard K. The role of therapeutic alliance in alcohol and drug abuse treatment outcome. 67th Annual Scientific Meeting of the College on Problems of Drug Dependence. 2005; Vol. 67:Cochrane ID: CN00591076

Ceperich 2002 \{published data only\}

* Ceperich SD, Ingersoll KS, Nettleman MD. Preventing alcoholexposed pregnancies in college women. Drug and Alcohol Dependence 2002;66 Suppl 1:29.

Chapman 2009 \{published data only\}

* Chapman S. With youth smoking at historical lows, how influential is movie smoking on uptake?. Addiction 2009;104(5): $824-5$.
Chavez 2003 \{published data only\}

* Chavez R, Miller WR, Tonigan JS. Negative consequences, substance use, and motivation for change: a predictive model of drug abusers motivation to change behavior. 65th Annual Scientific Meeting of the College on Problems of Drug Dependence. 2003; Vol. 65:Cochrane ID: CN-00462116.

Clinton-Sherrod 2008 \{published data only\} * Clinton-Sherrod AM, Morgan-Lopez AA, Olmstead KLR, Brown JM. The effects of a Motivational Interviewing intervention to reduce college drinking on reports of pressured or force sex at 3month follow up. Alcoholism-Clinical and Experimental Research 2008;32(6):191A.

Corrigan 2005 \{published data only\} Corrigan JD, Bogner J, Lamb-Hart G, Heinemann AW, Moore D. Increasing substance abuse treatment compliance for persons with traumatic brain injury. Psychology of Addictive Behaviors 2005;19 (2):131-9.

D'Angelo 2005 \{published data only\}

* D'Angelo MS. A comparative study of motivational interviewing and traditional treatment approach on movement along stages of change, treatment completion, compliance with aftercare plan, and length of abstinence. Dissertation Abstracts International: Section B: The Sciences and Engineering 2006; Vol. 66, issue 7B:3935.

Daeppen 2007 \{published data only\}

* Daeppen J-B, Bertholet N, Gmel G, Gaume J. Communication during brief intervention, intention to change, and outcome. Substance Abuse 2007;28(3):43-51.

Daley 1998 \{published data only\}

* Daley DC, Salloum IM, Zuckoff A, Kirisci L, Thase ME. Increasing treatment adherence among outpatients with depression and cocaine dependence: results of a pilot study. American Journal of Psychiatry 1998;155(11):1611-3.

Davidson 2007 \{published data only\}

* Davidson D, Gulliver SB, Longabaugh R, Wirtz PW, Swift R. Building better cognitive-behavioral therapy: is broad-spectrum treatment more effective than motivational-enhancement therapy for alcohol-dependent patients treated with naltrexone?. Journal of Studies on Alcohol 2007;68(2):238-47.

Davis 2003 \{published data only\}

* Davis TM, Baer JS, Saxon AJ, Kivlahan DR. Brief motivational feedback improves post-incarceration treatment contact among veterans with substance use disorders. Drug and Alcohol Dependence 2003;69(2):197-203

Demmel 2003 \{published data only\}

* Demmel R, Rist F, Hagen J, Aulhorn I, Scheuren B, Scherbaum N, Gesenhues S, Rollnick S. Secondary prevention beyond screening and brief advice. Suchtmedizin in Forschung und Praxis 2003;5(1):33-6.

Dench 2000 \{published data only\}

* Dench S, Bennett G. The impact of brief motivational intervention at the start of an outpatient day programme for alcohol dependence. Behavioral and Cognitive Psychotherapy 2000; 28:121-30.

Dent 2008 \{published data only\}

* Dent AW, Weiland TJ, Phillips GA, Lee NK. Opportunistic screening and clinician-delivered brief intervention for high-risk 
alcohol use among emergency department attendees: A randomised controlled trial. EMA - Emergency Medicine Australasia 2008;20(2): $121-8$

Dermen 2000 \{published data only\}

* Dermen KH, Thomas SN. A brief motivational approach to reducing drinking and sexual risk behavior among college students. Paper presented at the annual meeting of the Research Society on Alcoholism, Denver, CO. 2000.

Disney 2005 \{published data only\}

* Disney ER, Kidorf M, Kindbom K, Blucher J, Williams L, Depo J, et al.Opening doors to treatment: A voucher-enhanced motivational intervention for syringe exchange participants. 67 th Annual Scientific Meeting of the College on Problems of Drug Dependence. 2005; Vol. 67:Cochrane ID: CN-00526102.

Dunn 1997 \{published data only\} Dunn CW, Ries R. Linking substance abuse services with general medical care: Integrated, brief interventions with hospitalized patients. American Journal of Drug and Alcohol Abuse 1997;23(1): $1-13$.

Dunn 2004 \{published data only\}

* Dunn C, Droesch RM, Johnston BD, Rivara FP. Motivational interviewing with injured adolescents in the emergency department: In-session predictors of change. Behavioural and Cognitive Psychotherapy 2004;32(1):113-6.

Easton 2000 \{published data only\}

* Easton C, Swan S, Sinha R. Motivation to change substance use among offenders of domestic violence. Journal of Substance Abuse Treatment 2000;19(1):1-5.

Edwards 2006 \{published data only\}

* Edwards J, Elkins K, Hinton M, Harrigan SM, Donovan K, Athanasopoulos $\mathrm{O}$, et al.Randomized controlled trial of a cannabisfocused intervention for young people with first-episode psychosis. Acta Psychiatrica Scandinavica 2006;114:109-17.

\section{Fergusin 1998 \{published data only\}}

* Fergusin RT. Motivational interviewing with less motivated driving under the influence of alcohol second offenders with an exploration of the processes related to change. Dissertation Abstracts International: Section B: The Sciences and Engineering 1998; Vol. 59, issue 1B:0415.

Floyd 2007 \{published data only\}

* Floyd RL, Sobell M, Velasquez MM, Ingersoll K, Nettleman M, Sobell L, et al.Preventing alcohol-exposed pregnancies. A randomised controlled trial. American Journal of Preventive Medicine 2007;32(1):1-10.

Gauthier-Faille 2006 \{published data only\}

* Gauthier-Faille G. Outpatient treatment for substance dependence: using empirical findings about retention and substance use outcomes to shape treatment services. Dissertation 206; Vol. DAI-B 68/03.

\section{Gentilello 2001 \{published data only\}}

* Gentilello LM. Alcohol interventions in a trauma centre. Journal fur Anasthesie und Intensivbehandlung 2001;3:105-7.

Ginsburg 2001 \{published data only\}

* Ginsburg Joel Isser David. Using motivational interviewing to enhance treatment readiness in offenders with symptoms of alcohol dependence. Dissertation Abstracts International: Section B: The Sciences and Engineering 2001; Vol. 61, issue 8-B:Feb-B.

Godley 2010 \{unpublished data only\}

* Godley SH, Garner BR, Passetti LL, Funk RR, Dennis ML,

Godley MD. Adolescent outpatient treatment and continuing care: Main findings from a randomised clinical trial. Drug and Alcohol

Dependence 2010;110(1-2):44-54.

Gogineni 2005 \{published data only\}

* Gogineni A. Brief significant other-involved motivational interviewing with problem drinking primary care patients. Alcoholism-Clinical and Experimental Research 2005;29(5):74A.

Goti 2010 \{published data only\}

* Goti J, Diaz R, Serrano L, Gonzalez L, Calvo R, Gual A, et al.Brief intervention in substance-use among adolescent psychiatric patients: a randomised controlled trial. European Child \& Adolescent Psychiatry 2010;19(6):503-11.

Gray 2005 \{published data only\}

* Gray E, McCambridge J, Strang J. The effectiveness of motivational interviewing delivered by youth workers in reducing drinking, cigarette and cannabis smoking among young people: quasi-experimental pilot study. Alcohol and Alcoholism 2005;40(6): 535-9.

Gregory 2001 \{published data only\}

* Gregory Barry M. College alcohol and life skills study with student-athletes. Dissertation Abstracts International Section A: Humanities and Social Sciences 2001; Vol. 62, issue 1-A:Jul-A.

Gwadz 2008 \{published data only\}

* Gwadz MV, Leonard NR, Cleland CM, Riedel M, Arredondo GN, Wolfe H, et al.Behavioral interventions for HIV infected and uninfected mothers with problem drinking. Addiction Research and Theory 2008;16(1):47-65.

Handmaker 1999 \{published data only\}

* Handmaker NS, Miller WR, Manicke M. Findings of a pilot study of motivational interviewing with pregnant drinkers. Journal of Studies on Alcohol 1999;60(2):285-7.

Harper 2000 \{published data only\}

* Harper R, Hardy S. An evaluation of motivational interviewing as a method of intervention with clients in a probation setting. British Journal of Social Work 2000;30(3):393-400.

Haug 2004 \{published data only\}

* Haug NA, Svikis DS, Diclemente C. Motivational enhancement therapy for nicotine dependence in methadone-maintained pregnant women. Psychology of Addictive Behaviors 2004;18(3): 289-92.

Hayes 2007 \{published data only\}

* Hayes Brandon B. Comparing the effectiveness of cognitivebehavioral group therapy with and without motivational interviewing at reducing the social anxiety, alcohol consumption, and negative consequences of socially anxious college students. Dissertation Abstracts International: Section B: The Sciences and Engineering 2007; Vol. 67, issue 9-B:pp-B.

Heather 1996 \{published data only\}

* Heather N, Rollnick S, Bell A, Richmond R. Effects of brief counselling among male heavy drinkers identified on general hospital wards. Drug and Alcohol Review 1996;15(1):29-38. 
Hester 2005 \{published data only\}

* Hester RK, Squires DD, Delaney HD. The Drinker's Check-up: 12-month outcomes of a controlled clinical trial of a stand-alone software program for problem drinkers. Journal of Substance Abuse Treatment 2005;28(2):159-69.

Hickman 1999 \{published data only\}

* Hickman ME. The effects of personal feedback on alcohol intake in dually diagnosed clients: An empirical study of William R. Miller's motivational enhancement therapy. Dissertation Abstracts International: Section B: The Sciences and Engineering 1999; Vol. 60, issue 1-B:Jul-B.

Hicks 1999 \{published data only\}

* Hicks Thomas Edward. Coping with interpersonal conflict among alcohol abusers in outpatient treatment. Dissertation Abstracts International: Section B: The Sciences and Engineering 1999; Vol. 59, issue 8-B:Feb-B.

Holder 2000 \{published data only\}

* Holder HD, Cisler RA, Longabaugh R, Stout RL, Treno AJ,

Zweben A. Alcoholism treatment and medical care costs from Project MATCH. Addiction 2000;95(7):999-1013.

Hulse 2003 \{published data only\}

* Hulse GK, Tait RJ. Five-year outcomes of a brief alcohol intervention for adult in-patients with psychiatric disorders. Addiction 2003;98(8):1061-8.

Johnson 2006 \{published data only\}

* Johnsson KO, Berglund M. Comparison between a cognitive behavioural alcohol programme and post-mailed minimal intervention in high-risk drinking university freshmen: results from a randomised controlled trial. Alcohol and Alcoholism 2006;41(2): $174-80$.

Juarez 2006 \{published data only\}

* Juarez P, Walters ST, Daugherty M, Radi C. A randomised trial of motivational interviewing and feedback with heavy drinking college students. Journal of Drug Education 2006;36(3):233-46.

Jungerman 2007 \{published data only\}

* Jungerman FS, Andreoni S, Laranjeira R. Short term impact of same intensity but different duration interventions for cannabis users. Drug and Alcohol Dependence 2007;90(2-3):120-7.

Kanouse 2005 \{published data only\}

* Kanouse DE, Bluthenthal RN, Bogart L, Iguchi MY, Perry S, Sand K, et al.Recruiting drug-using men who have sex with men into behavioral interventions: a two-stage approach. Journal of Urban Health 2005;82 (1 Suppl 1):109-19.

Kidorf 2005 \{published data only\}

${ }^{*}$ Kidorf M, Disney E, King V, Kolodner K, Beilenson P, Brooner RK. Challenges in motivating treatment enrolment in community syringe exchange participants. Journal of Urban Health 2005;82(3): 456-67.

Kidorf 2009 \{published data only\}

* Kidorf M, King VL, Neufeld K, Peirce J, Kolodner K, Brooner

RK. Improving substance abuse treatment enrolment in community syringe exchangers. Addiction 2009;104(5):786-95.

Kinlock 2005 \{published data only\}

* Kinlock TW, Sears EA, O'Grady KE, Callaman JM, Brown BS. The effect of motivational enhancement therapy on drug abuse treatment retention among drug court clients. Journal of Community Corrections 2005;15:11-7.

Kuchipudi 1990 \{published data only\}

* Kuchipudi V, Hobein K, Flickinger A, Iber FL. Failure of a 2hour motivational intervention to alter recurrent drinking behavior in alcoholics with gastrointestinal disease. Journal of Studies on Alcohol 1990;51(4):356-60.

Lachance 2004 \{published data only\}

* Lachance H. Group motivational intervention for underage college student drinkers in mandated university-based programming. Dissertation Abstracts International: Section B: The Sciences and Engineering 2004; Vol. 65, issue 6-B:pp-B.

Larimer 2001 \{published data only\}

* Larimer ME, Turner AP, Anderson BK, Fader JS, Kilmer JR, Palmer RS, et al.Evaluating a brief alcohol intervention with fraternities. Journal of Studies on Alcohol 2001;62(3):370-80.

Longabaugh 2001 \{published data only\}

Baird J, Longabaugh R, Lee CS, Nirenberg TD, Woolard R, Mello $\mathrm{MJ}$, et al.Treatment completion in a brief motivational intervention in the emergency department: The effect of multiple interventions and therapists' behavior. Alcoholism: Clinical and Experimental Research 2007;31(Suppl. 3):Oct-75S.

* Longabaugh R, Woolard RF, Nirenberg TD, Minugh AP, Becker $\mathrm{B}$, Clifford Pr, et al.Evaluating the effects of a brief motivational intervention for injured drinkers in the emergency department. Journal of Studies on Alcohol 2001;62:806-16.

Longabaugh 2009 \{published data only\}

* Longabaugh R, Wirtz PW, Gulliver SB, Davidson D. Extended naltrexone and broad spectrum treatment or motivational enhancement therapy. Psychopharmacology 2009;206(3):367-76.

Lozano 2006 \{published data only\}

* Lozano BE, Stephens RS, Roffman RA. Abstinence and moderate use goals in the treatment of marijuana dependence. Addiction 2006;101(11):1589-97.

Magill 2009 \{published data only\}

* Magill M, Barnett NP, Apodaca TR, Rohsenow DJ, Monti PM. The Role of Marijuana Use in Brief Motivational Intervention With Young Adult Drinkers Treated in an Emergency Department. Journal of Studies on Alcohol and Drugs 2009;70(3):409-13.

Mahmood 2002 \{published data only\}

* Mahmood D, Foote J, Kosanke N, Rosenblum A, Magura S. Group motivational intervention in drug abuse treatment. Drug and Alcohol Dependence 2002;66:S109-S10.

Marlatt 1998 \{published data only\}

* Marlatt GA, Baer JS, Kivlahan DR, Dimeff LA, Larimer ME, Quigley LA, et al.Screening and brief intervention for high-risk college student drinkers: results from a 2-year follow-up assessment. Journal of Consulting and Clinical Psychology 1998;66(4):604-15.

Martino 2000 \{published data only\}

* Martino S, Carroll KM, O’Malley SS, Rounsaville BJ.

Motivational interviewing with psychiatrically ill substance abusing patients. The American Journal on Addictions 2000;9(1):88-91.

Mausbach 2007 \{published data only\}

* Mausbach BT, Semple SJ, Strathdee SA, Zians J, Patterson TL. Efficacy of a behavioral intervention for increasing safer sex 
behaviours in HIV-negative, heterosexual methamphetamine users: Results from the fast-lane study. Annals of Behavioral Medicine 2007;34(3):263-74.

\section{McCambridge 2004 \{published data only\}}

* McCambridge J, Strang J. The efficacy of single-session motivational interviewing in reducing drug consumption and perceptions of drug-related risk and harm among young people: results from a multi-site cluster randomised trial. Addiction 2004; 99(1):39-52.

McDowell 2006 \{published data only\}

* McDowell D, Levin FR, Brooks DJ, Carpenter K, Garawi F. Treatment of cannabis-dependent treatment seekers: A doubleblind comparison of nefazodone, bupropion and placebo. 68th Annual Scientific Meeting of the College on Problems of Drug Dependence. 2006; Vol. 68:Cochrane ID: CN-00590636.

Mckee 2007 \{published data only\}

* Mckee SA, Carroll KM, Sinha R, Robinson JE, Nich C, Cavallo $\mathrm{D}$, et al.Enhancing brief cognitive-behavioral therapy with motivational enhancement techniques in cocaine users. Drug and Alcohol Dependence 2007;91(1):97-101.

McNally 2005 \{published data only\}

* McNally AM, Palfai TP, Kahler CW. Motivational interventions for heavy drinking college students: examining the role of discrepancy-related psychological processes. Psychology of Addictive Behaviors 2005;19(1):79-87.

Michael 2006 \{published data only\}

* Michael KD, Curtin L, Kirkley DE, Jones DL, Harris R. Groupbased motivational interviewing for alcohol use among college students: An exploratory study. Professional Psychology-Research and Practice 2006;37(6):629-34.

Miller 2005 \{published data only\}

* Miller William R. Motivational interviewing and the incredible shrinking treatment effect. Addiction 2005;100:470-8.

Mitcheson 2007 \{published data only\}

* Mitcheson L, McCambridge J, Byrne S. Pilot cluster-randomised trial of adjunctive motivational interviewing to reduce crack cocaine use in clients on methadone maintenance. European Addiction Research 2007;13(1):6-10.

Monti 1999 \{published data only\}

* Monti PM, Colby SM, Barnett NP, Spirito A, Rohsenow DJ, Myers $\mathrm{M}$, et al.Brief intervention for harm reduction with alcoholpositive older adolescents in a hospital emergency department. Journal of Consulting and Clinical Psychology 1999;67(6):989-94.

\section{Monti 2007 \{published data only\}}

* Monti PM, Barnett NP, Colby SM, Gwaltney CJ, Spirito A, Rohsenow DJ, et al.Motivational interviewing versus feedback only in emergency care for young adult problem drinking. Addiction 2007;102(8):1234-43.

Morgenstern 2007 \{published data only\}

* Morgenstern J, Irwin TW, Wainberg ML, Parsons JT, Muench F, Bux DA Jr, et al.A randomised controlled trial of goal choice interventions for alcohol use disorders among men who have sex with men. Journal of Consulting and Clinical Psychology 2007;75(1): $72-84$.

\section{Mullins 2004 \{published data only\}}

* Mullins SA, Suarez M, Ondersma SJ, Page MC. The impact of motivational interviewing on substance abuse treatment retention: A randomised control trial of women involved with child welfare. Journal of Substance Abuse Treatment 2004;27(1):51-8.

Murphy 2001 \{published data only\}

* Murphy JG, Duchnick JJ, Vuchinich RE, Davison JW, Karg RS, Olson AM, et al.Relative efficacy of a brief motivational intervention for college student drinkers. Psychology of Addictive Behaviors 2001;15(4):373-9.

Murphy 2003 \{published data only\}

* Murphy James G. A comparison of personal feedback for college student drinkers delivered with and without a counselling session. Dissertation Abstracts International: Section B: The Sciences and Engineering 2003; Vol. 64, issue 6-B:pp-B.

Murphy 2004 \{published data only\}

* Murphy JG, Benson TA, Vuchinich RE, Deskins MM, Eakin D, Flood AM, et al.A comparison of personalized feedback for college students drinkers delivered with and without a motivational interview. Journal of Studies on Alcohol 2004;65:200-3.

Noonan 2001 \{published data only\}

* Noonan WC. Group motivational interviewing as an enhancement to outpatient alcohol treatment. Dissertation Abstracts International: Section B: The Sciences and Engineering 2001; Vol. 61, issue 12-B:Jun-B.

Oliveira 2008 \{published data only\}

* Oliveira MD, Andretta I, Rigoni MD, Szupszynski KPD. Motivational Interview with alcoholics: A longitudinal study abstract. Psicologia-Reflexao e Critica 2008;21(2):261-6.

Ondersma 2007 \{published data only\}

* Ondersma SJ, Svikis DS, Schuster CR. Computer-based brief intervention a randomised trial with postpartum women. American Journal of Preventive Medicine 2007;32(3):231-8.

\section{Parsons 2007 \{published data only\}}

* Parsons JT, Golub SA, Rosof E, Holder C. Motivational interviewing and cognitive-behavioral intervention to improve HIV medication adherence among hazardous drinkers: A randomized controlled trial. Journal of Acquired Immune Deficiency Syndromes 2007;46(4):443-50.

Patterson 2008 \{published data only\}

* Patterson DA. Motivational interviewing: Does it increase clients' retention in intensive outpatient treatment?. Substance Abuse 2008; 29(1):17-23.

Pavone 2002 \{published data only\}

* Pavone SA. Sobriety management: Healthy living in recovery. retention in treatment and outcome study. Dissertation Abstracts International: Section B: The Sciences and Engineering 2002; Vol. 62, issue 11-B:May-B.

Rao 1999 \{published data only\}

* Rao SA. The short-term impact of the family check-up: A brief motivational intervention for at-risk families. Dissertation Abstracts International: Section B: The Sciences and Engineering 1999; Vol. 59, issue 7-B:Jan-B. 
Reid 2005 \{published data only\}

* Reid SC, Teesson M, Sannibale C, Matsuda M, Haber PS. The efficacy of compliance therapy in pharmacotherapy for alcohol dependence: a randomised controlled trial. Journal of Studies on Alcohol 2005;66(6):833-41.

Rimmele 1998 \{published data only\}

* Rimmele CT, Bombardier CH. Motivational interviewing to prevent alcohol abuse after TBI. Rehabilitation Psychology 1998;43 (2):182-3.

Samet 2005 \{published data only\}

* Samet JH, Horton NJ, Meli S, Dukes K, Tripps T, Sullivan L, et al.A randomised controlled trial to enhance antiretroviral therapy adherence in patients with a history of alcohol problems. Antiviral Therapy 2005;10(1):83-93.

Sanchez 2001 \{published data only\}

* Sanchez FP. A values-based intervention for alcohol abuse. Dissertation Abstracts International: Section B: The Sciences and Engineering 2001; Vol. 61, issue 7-B:Jan-B.

Sanchez-Craig 1996 \{published data only\}

* Sanchez-Craig M, Davila R, Cooper G. A self-help approach for high-risk drinking: effect of an initial assessment. Journal of Consulting and Clinical Psychology 1996;64(4):694-700.

Santa Ana 2005 \{published data only\}

* Santa Ana EJ. Efficacy of group motivational interviewing (GMI) for psychiatric inpatients with chemical dependence. Dissertation Abstracts International: Section B: The Sciences and Engineering 2005; Vol. 66, issue 5-B:pp-B.

Santa Ana 2007 \{published data only\}

* Santa Ana EJ, Wulfert E, Nietert PJ. Efficacy of group motivational interviewing (GMI) for psychiatric inpatients with chemical dependence. Journal of Consulting and Clinical Psychology 2007;75(5):816-22.

Saunders 1995 \{published data only\}

* Saunders B, Wilkinson C, Phillips M. The impact of a brief motivational intervention with opiate users attending a methadone programme. Addiction 1995;90(3):415-24.

Schilling 2002 \{published data only\}

* Schilling RF, El-Bassel N, Finch JB, Roman RJ, Hanson M. Motivational interviewing to encourage self-help participation following alcohol detoxification. Research on Social Work Practice 2002;12(6):711-30.

Scott 2002 \{published data only\}

* Scott CK, Dennis ML. Preliminary findings from the early reintervention (ERI) experiment with chronic substance abusers. Drug and Alcohol Dependence 2002; Vol. 66:S161.

Scott 2009 \{published data only\}

* Scott CK, Dennis ML. Results from two randomised clinical trials evaluating the impact of quarterly recovery management checkups with adult chronic substance users. Addiction 2009;104(6):959-71.

Sears 2006 \{published data only\}

* Sears EA, Kinlock TW, O’Grady KE, Callaman JM, Brown BS. The complex issue of treatment readiness in an offender population. 68th Annual Scientific Meeting of the College on Problems of Drug Dependence. 2006; Vol. Cochrane ID: CN-00591317RC.
Sinha 2003 \{published data only\}

* Sinha R, Easton C, Renee-Aubin L, Carroll KM. Engaging young probation-referred marijuana-abusing individuals in treatment: a pilot trial. American Journal on Addictions 2003;12(4):314-23.

Sitharthan 1999 \{published data only\}

* Sitharthan T, Singh S, Kranitis P, Currie J, Freeman P, Murugesan $\mathrm{G}$, et al.Integrated drug and alcohol intervention: development of an opportunistic intervention program to reduce alcohol and other substance use among psychiatric patients. Australian and New Zealand Journal of Psychiatry 1999;33(5):676-83.

Sobell 2002 \{published data only\}

* Sobell LC, Sobell MB, Leo GI, Agrawal S, Johnson-Young L, Cunningham JA. Promoting self-change with alcohol abusers: a community-level mail intervention based on natural recovery studies. Alcoholism: Clinical and Experimental Research 2002;26(6): 936-48.

Soderstrom 2007 \{published data only\}

* Soderstrom CA, DiClemente CC, Dischinger PC, Hebel JR, Mcduff DR, Auman KM, et al.A controlled trial of brief intervention versus brief advice for at-risk drinking trauma centre patients. The Journal of Trauma 2007;62(5):1102-11.

Stein 2002a \{published data only\}

* Stein LAR, Lebeau-Craven R. Motivational interviewing and relapse prevention for DWI: A pilot study. Journal of Drug Issues 2002;32(4):1051-69.

Stein 2006 \{published data only\}

* Stein LA, Colby SM, Barnett NP, Monti PM, Golembeske C, Lebeau-Craven R. Effects of motivational interviewing for incarcerated adolescents on driving under the influence after release. American Journal on Addictions 2006;15 Suppl 1:50-7. Stein LAR, Colby SM, Barnett NP, Monti PM, Golembeske C, Lebeau-Craven R, et al.Enhancing substance abuse treatment engagement in incarcerated adolescents. Psychological Services 2006; 3(1):25-34.

Stein 2006a \{published data only\}

* Stein MD, Weinstock MC, Herman DS, Anderson BJ, Anthony JL, Niaura R. A smoking cessation intervention for the methadonemaintained. Addiction 2006;101(4):599-607.

Stephens 2000 \{published data only\}

* Stephens RS, Roffman RA, Curtin L. Comparison of extended versus brief treatments for marijuana use. Journal of Consulting \& Clinical Psychology 2000;68(5):898-908.

Stephens 2002 \{published data only\}

* Stephens RS, Babor TF, Kadden R, Miller M, Marijuana Treatment Project Research Group. The Marijuana Treatment Project: rationale, design and participant characteristics. Addiction 2002;97 Suppl 1:109-24.

Stockwell 1986 \{published data only\}

* Stockwell T, Gregson A. Motivational interviewing with problem drinkers - impact on attendance, drinking and outcome. British Journal of Addiction 1986;81(5):713.

Stotts 2004 \{published data only\}

* Stotts AL, Potts G, Ingersoll G, Schmitz JM, Grabowski J. Brief motivational interviewing with psychophysiologic feedback for the treatment of cocaine abuse. Sixty Sixth Annual Scientific Meeting 
of the College on Problems of Drug Dependence. 2004; Vol. 66: Cochrane ID: CN-00496619.

Swanson 1999 \{published data only\}

* Swanson AJ, Pantalon MV, Cohen KR. Motivational interviewing and treatment adherence among psychiatric and dually diagnosed patients. Journal of Nervous and Mental Disease 1999;187(10): $630-5$.

Tapert 2003 \{published data only\}

* Tapert SF, Colby SM, Barnett NP, Spirito A, Rohsenow DJ, Myers MG, et al.Depressed mood, gender, and problem drinking in youth. Journal of Child and Adolescent Substance Abuse 2003;12(4):55-68.

Tevyaw 2007 \{published data only\}

* Tevyaw TO, Borsari B, Colby SM, Monti PM. Peer enhancement of a brief motivational intervention with mandated college students. Psychology of Addictive Behaviors 2007;21(1):114-9.

Thevos 1998 \{published data only\}

* Thevos AK. Alcoholism with and without social phobia: A comparison of pre and post treatment differences in drinking and social support. Dissertation Abstracts International: Section B: The Sciences and Engineering 1998; Vol. 58, issue 11-B:May-B.

Thush 2007 \{published data only\}

* Thush C, Wiers RW, Theunissen N, Van den Bosch J,

Opdenacker J, van Empelen P, et al.A randomised clinical trial of a targeted intervention to moderate alcohol use and alcohol-related problems in at-risk adolescents. Pharmacology, Biochemistry, and Behavior 2007;86(2):368-76.

Tirado 2005 \{published data only\}

* Tirado CF, Maullin N, Kyle K, Klein L, O’Brien C. An open label pilot trial of atomoxetine and four-session motivational interviewing for cannabis dependence. Neuropsychopharmacology 2005;30:S216-7.

Vanderburg 2003 \{published data only\}

* Vanderburg SA. Motivational interviewing as a precursor to a substance abuse program for offenders. Dissertation Abstracts International: Section B: the Sciences and Engineering 2003; Vol. 63, issue 9-B:4354.

Velasquez 2009 \{published data only\}

* Velasquez MM, von Sternberg K, Johnson DH, Green C,

Carbonari JP, Parsons JT. Reducing sexual risk behaviours and alcohol use among HIV-positive men who have sex with men: a randomised clinical trial. Journal of Consulting and Clinical Psychology 2009;77(4):657-67.

Wain 2006 \{published data only\}

* Wain M, Wilbourne PL, Harris K, Teleki J, Burling T, Lovett S. Brief motivational interview improves treatment adherence in homeless men with severe drug and alcohol dependence. Alcoholism-Clinical and Experimental Research 2006;30(6):99A.

Walters 2000 \{published data only\}

* Walters ST, Bennet ME, Miller JH. Reducing alcohol use in college students: A controlled trial of two brief interventions. Journal of Drug Education 2000;30(3):361-72.

Walton 2010 \{published data only\}

* Walton MA, Chermack ST, Shope JT, Bingham CR, Zimmerman MA, Blow FC, et al.Effects of a brief intervention for reducing violence and alcohol misuse among adolescents. a randomised controlled trial. JAMA 2010;304(5):527-35.

Weinrieb 2005 \{published data only\}

* Weinrieb RM, Van Horn DVH, Lin YT, De Piano M, Massoth $\mathrm{K}$, Lucey MR. A controlled study of motivational enhancement therapy (MET) vs. community alcoholism treatment for alcoholic liver transplant candidates. Alcoholism-Clinical and Experimental Research 2005;29(5):76A.

Wells 1998 \{published data only\}

* Wells EA, Calsyn DA, Clark LL, Jackson TR. Motivational enhancement to increase treatment readiness among stimulant users: A pilot evaluation. NIDA Research Monograph. 1998; Vol. Cochrane ID: CN-00591223.

Wells 2004 \{published data only\}

* Wells EA, Beadnell B, Calsyn DA, Rosengren DB, Nahom D, Ricardo-Bulis E, et al.Motivational enhancement to decrease drug use among cocaine users: Six-month follow-up results. Sixty Sixth Annual Scientific Meeting of the College on Problems of Drug Dependence. 2004; Vol. 66:Cochrane ID: CN-00496626.

\section{Wertz 1994 \{published data only\}}

* Wertz JS. The effect of motivational interviewing on treatment participation, self-efficacy, and alcohol use at follow-up in inpatient alcohol dependent adults. Dissertation Abstracts International: Section B: The Sciences and Engineering 1994; Vol. 55, issue 1-B: $\mathrm{pp}-\mathrm{B}$.

Whitten 2006 \{published data only\}

* Whitten L. Checkup System Catches Relapse Early and Facilitates Return to Treatment. NIDA Notes. 2006; Vol. 20, issue 6:1-3.

Wilbourne 2005 \{published data only\}

* Wilbourne PL. An empirical basis for the treatment of alcohol problems. Dissertation Abstracts International: Section B: The Sciences and Engineering 2005; Vol. 66, issue 5-B:pp-B.

Woodall 2007 \{published data only\}

* Woodall WG, Delaney HD, Kunitz SJ, Westerberg VS, Zhao H. A randomised trial of a DWI intervention program for first offenders: intervention outcomes and interactions with antisocial personality disorder among a primarily American-Indian sample. Alcoholism, Clinical and Experimental Research 2007;31(6):974-87.

Woody 2001 \{published data only\}

* Woody GE, McLellan AT, Bovasso G, Kurtz J, O’Brien CP.

Methadone maintenance and opioid positive urine: a test of $80 \mathrm{mg}$ vs $120 \mathrm{mg}$ and MET vs DC. Drug and Alcohol Dependence 2001;63 Suppl 1:173.

Yonkers 2009 \{published data only\}

* Yonkers KA, Howell HB, Allen AE, Ball SA, Pantalon MV, Rounsaville BJ. A treatment for substance abusing pregnant women. Archives of Womens Mental Health 2009;12(4):221-227.

Zahradnik 2009 \{published data only\}

* Zahradnik A, Otto C, Crackau B, Löhrmann I, Bischof G, John $\mathrm{U}$, et al.Randomized controlled trial of a brief intervention for problematic prescription drug use in non-treatment-seeking patients. Addiction 2009;104(1):109-17.

Zule 2009 \{published data only\}

* Zule WA, Costenbader EC, Coomes CM, Wechsberg WM. Effects of a hepatitis $\mathrm{C}$ virus educational intervention or a 
motivational intervention on alcohol use, injection drug use, and sexual risk behaviors among injection drug users. American Journal of Public Health 2009;99 Suppl 1:S180-S186.

\section{References to studies awaiting assessment}

\section{Barrowclough 2010 \{published data only\}}

Barrowclough C, Haddock G, Beardmore R, Conrod P, Craig T, Davies L, Dunn G, Lewis S, Moring J, Tarrier N, Wykes T. Evaluating integrated MI and CBT for people with psychosis and substance misuse: Recruitment, retention and sample characteristics of the MIDAS trial. Addictive Behaviors 2009;34(10):859-866. Barrowclough C, Haddock G, Tarrier N, Lewis SW, Moring J, O’Brien R, Schefield N, McGovern J. Randomized controlled trial of motivational interviewing, cognitive behavior therapy, and family intervention for patients with comorbid schizophrenia and substance use disorders. American Journal of Psychiatry 2001;158 (10):1706-1713.

Barrowclough C, Haddock G, Wykes T, Beardmore R, Conrod P, Craig $\mathrm{T}$, et al.Integrated motivational interviewing and cognitive behavioural therapy for people with psychosis and comorbid substance misuse: randomised controlled trial. BMJ 2010;341 (1468-5833 (Electronic), 0959-535X (Linking)):c6325.

\section{Walters 2010 \{published data only\}}

Walters ST, Vader AM, Nguyen N, Harris TR, Eells J. Motivational Interviewing as a Supervision Strategy inProbation: A Randomized Effectiveness Trial. Journal of Offender Rehabilitation 2010;49(5): 309-323.

\section{References to ongoing studies}

\section{Dubertret 2010 \{unpublished data only\}}

Effect of motivational therapy on schizophrenia with cannabis misuse.. Ongoing study November 2008.

\section{Forsberg 2010 \{unpublished data only\}}

Effects of Motivational Interviewing in Prison.. Ongoing study April 2004..

Hansen 2010 \{unpublished data only\}

Brief intervention for heavy drinkers.. Ongoing study January 2008.

\section{Morken 2010 \{unpublished data only\}}

Motivational interviewing to acutely admitted psychiatric patients with comorbid substance use. Ongoing study October 2004..

\section{Additional references}

\section{Andreasson 2003}

Andreasson S, Ojehagen A. Psychosocial treatment for alcohol dependence. In: Berglund M, Thelander S, Jonsson E editor(s). Treating Alcohol and Drug Abuse: An Evidence Based Review. Weinheim: Wiley-VCH, 2003:43-188.

\section{APA 1987}

American Psychiatric Association. Diagnostic and Statistical Manual of Mental Disorders. 3rd Edition. Washington, DC: American Psychiatric Association, 1987.

\section{APA 1994}

American Psychiatric Association. Diagnostic and Statistical Manual of Mental Disorders. 4th Edition. Washington, DC: American Psychiatric Association, 1994.

APA 2000

American Psychiatric Association. Diagnostic and Statistical Manual of Mental Disorders. 4th Edition. Washington, DC: American Psychiatric Association, 2000.

\section{Apodaca 2009}

Apodaca TR, Longabaugh R. Mechanisms of change in motivational interviewing: a review and preliminary evaluation of the evidence. Addiction 2009;104:705-15.

\section{Borenstein 2005}

Borenstein M, Hedges L, Higgins J, Rothstein H. Comprehensive Meta-Analysis Version 2. Comprehensive Meta-Analysis Version 2. Englewood, NJ: BioStat, 2005.

\section{Burke 2003}

Burke BL, Arkowitz H, Mendola M. The efficacy of motivational interviewing: A meta-analysis of controlled clinical trials. Journal of Consulting and Clinical Psychology 2003;71(5):843-61.

Burke 2004

Burke BL, Dunn CW, Atkins DC, Phelps JS. The emerging evidence base for motivational interviewing: A meta-analytic and qualitative inquiry. Journal of Cognitive Psychotherapy: An International Quarterly 2004;18:309-22.

Carey 2007

Carey KB, Scott-Sheldon LA, Carey MP, DeMartini KS. Individual-level interventions to reduce college student drinking: a meta-analytic review. Addictive Behaviors 2007;32(11):2469-94.

\section{Darke 1991}

Darke S, Ward J, Hall W, Heather N, Wodak A. The Opiate Treatment Index (OTI) Researcher's Manual. Vol. NDARC Technical Report No II, Sydney: National Drug and Alcohol Research Centre, 1991.

\section{Darke 1992}

Darke S, Hall W, Wodak A, Heather N, Ward J. Development and validation of a multi-dimensional instrument for assessing outcome of treatment among opiate users: the Opiate Treatment Index. British Journal of Addiction 1992;87:733-42.

\section{deWildt 2002} deWildt WAJM, Schippers GM, van den Brink W, Potgieter AS, Deckers F, Bets D. Does psychosocial treatment enhance the efficacy of Acamprosate in patients with alcohol problems?. Alcohol and Alcoholism 2002;37:375-82.

\section{Dunn 2001}

Dunn C, Deroo L, Rivara FP. The use of brief interventions adapted from motivational interviewing across behavioral domains: a systematic review. Addiction 2001;96(12):1725-42.

Emmelkamp 2006

Emmelkamp PMG, Vedel E. Evidence-based treatment of alcohol and drug abuse. New York: Routledge/Taylor \& Francis, 2006.

\section{Grenard 2006}

Grenard JL, Ames SL, Pentz MA, Sussman S. Motivational interviewing with adolescents and young adults for drug-related 
problems. International Journal of Adolescent Medicine and Health 2006;18(1):53-67.

\section{Guyatt 2008}

Guyatt GH, Oxman AD, Vist GE, Kunz R, Falck-Ytter Y, AlonsoCoello P, Schünemann HJ. GRADE: an emerging consensus on rating quality of evidence and strength of recommendations. British Medical Journal 2008;336(7650):924-926.

\section{Heather 1993}

Heather N, Rollnick S. Readiness to Change Questionnaire: User's Manual (Revised Edition). Vol. NDARC Technical Report No. 19, Sydney: National Drug and Alcohol Research Centre, 1993.

\section{Hettema 2005}

Hettema J, Steele J, Miller WR. Motivational interviewing. Annu.Rev.Clin.Psychol. 2005;1(1548-5943 (Print)):91-111.

\section{Higgins 2009}

Higgins JPT, Green S (editors). Cochrane Handbook for Systematic Reviews of Interventions Version 5.0.2 [updated September 2009]. Available from www.cochrane-handbook.org. The Cochrane Collaboration, 2009.

\section{Lai 2010}

Lai DTC, Cahill K, Quin Y, Tang JL. Motivational interviewing for smoking cessation. Cochrane Database of Systematic Reviews 2010, Issue 1. [DOI: 10.1002/14651858.CD006936.pub2]

\section{Lambert 1986}

Lambert, M. Implications of psychotherapy outcome research for eclectic psychotherapy. In: J. C. Norcross editor(s). Handbook of Eclectic Psychotherapy. New York:: Brunner Mazel, 1986:436-462.

\section{Larimer 2007}

Larimer ME, Cronce JM. Identification, prevention, and treatment revisited: individual-focused college drinking prevention strategies 1999-2006. Addictive Behaviors 2007;32(11):2439-2468.

\section{Lundahl 2010}

Lundahl BW, Kunz C, Brownell C, Tollefson D, Burke BL. A metaanalysis of motivational interviewing: twenty-five years of empirical studies. Research on Social Work Practice 2010;20(2):137-60.

\section{Madson 2006}

Madson MB, Campbell TC. Measures of fidelity in motivational enhancement: A systematic review. Journal of Substance Abuse Treatment 2006;31:67-73.

\section{Miller 1983}

Miller W. Motivational interviewing with problem drinkers. Behavioural Psychotherapy 1983;11:141-72.

\section{Miller 1991}

Miller WR, Rollnick S. Motivational interviewing: preparing people to change addictive behavior. New York: Guilford Press, 1991.

\section{Moyers 2005}

Moyers TB, Martin T, Manuel JK, Hendrickson SML, Miller WR. Assessing competence in the use of motivational interviewing. Journal of Substance Abuse Treatment 2005;28:19-26.

\section{Nahom 2005}

Nahom Deborah. Motivational interviewing and behavior change: How can we know how it works?. Journal of Evidence-Based Social Work 2005;2:55-78.

\section{Pogue 1997}

Pogue JM, Yusuf S. Cumulating evidence from randomised trials: utilizing sequential monitoring boundaries for cumulative metaanalysis. Controlled ClinicalTrials 1997;18(6):580-93.

\section{Project MATCH 1997}

Project MATCH Research Group. Matching Alcoholism

Treatments to Client Heterogeneity: Project MATCH posttreatment drinking outcomes. Journal of Studies on Alcohol 1997;58(1):7-29.

\section{Rogers 1951}

Rogers, C.R. Client-centered therapy. Client-centered therapy.

Boston: Houston-Mifflin, 1951.

Rubak 2005

Rubak S, Sandbaek A, Lauritzen T, Christensen B. Motivational interviewing: a systematic review and meta-analysis. British Journal of General Practice 2005;55(513):305-12.

\section{Sobell 1992}

Sobell LC, Sobell MB. Time line follow-back: A technique for assessing self-reported ethanol consumption. In: Allen J, Litten RZ editor(s). Measuring alcohol consumption: Psychosocial and biological methods. Totowa, NJ: The Humana Press, Inc, 1992:41-72.

\section{Vasilaki 2006}

Vasilaki EI, Hosier SG, Cox WM. The efficacy of motivational interviewing as a brief intervention for excessive drinking: A metaanalytic review. Alcohol and Alcoholism 2006;41(3):328-35.

\section{Walach 2001}

Walach Harald. The efficacy paradox in randomised controlled trials of CAM and elsewhere: beware of the placebo trap. The Journal of Alternative and Complementary Medicine 2001;7:213-8.

\section{White 1989}

White HR, Labouvie EW. Towards the assessment of adolescent problem drinking. Journal of Studies on Alcohol 1989;50:30-7.

\section{WHO 1993}

World Health Organization. The ICD-10 Classification of Mental and Behavioural Disorders. Diagnostic Criteria for Research. Geneva: WHO, 1993.

\section{WHO 2009}

World Health Organization. Management of substance abuse. http://www.who.int/substance' abuse/facts/en/index.html downloaded on April 28th 2009.

* Indicates the major publication for the study 
CHARACTERISTICS OF STUDIES

Characteristics of included studies [ordered by study ID]

Anton 2005

\begin{tabular}{ll}
\hline Methods & RCT. \\
\hline Participants & 160 outpatient alcoholics from the USA. \\
\hline Interventions & $\begin{array}{l}\text { 1. naltrexone + MET }(\mathrm{n}=41) \\
\text { 2. placebo }+ \text { MET }(\mathrm{n}=39) \\
\text { 3. naltrexone + CBT }(\mathrm{n}=39) \\
\text { 4. placebo }+ \text { CBT }(\mathrm{n}=41)\end{array}$ \\
\hline
\end{tabular}

Outcomes

Physiological primary: Blood GGT, CDT, urine drug screen.

Non-physiological primary: Number relapsed, drinks per drinking day, percent abstinent.

Secondary: None.

\section{Notes}

Risk of bias

\begin{tabular}{|c|c|c|}
\hline Bias & Authors' judgement & Support for judgement \\
\hline $\begin{array}{l}\text { Random sequence generation (selection } \\
\text { bias) }\end{array}$ & Unclear risk & $\begin{array}{l}\text { "Subjects were randomly assigned to } 1 \text { of } 4 \text { treatment condi- } \\
\text { tions". }\end{array}$ \\
\hline Allocation concealment (selection bias) & Unclear risk & Insufficient information to permit judgment. \\
\hline $\begin{array}{l}\text { Blinding (performance bias and detection } \\
\text { bias) } \\
\text { Patients and providers }\end{array}$ & Low risk & $\begin{array}{l}\text { No blinding, but most outcomes were physiological and also } \\
\text { used to validate self-reports, and not likely to be influenced by } \\
\text { lack of blinding. }\end{array}$ \\
\hline $\begin{array}{l}\text { Blinding (performance bias and detection } \\
\text { bias) } \\
\text { Assessors }\end{array}$ & Low risk & $\begin{array}{l}\text { Insufficient information to know whether assessors were } \\
\text { blinded. But most outcomes were physiological and also used to } \\
\text { validate self-reports, and not likely to be influenced by lack of } \\
\text { blinding. }\end{array}$ \\
\hline $\begin{array}{l}\text { Incomplete outcome data (attrition bias) } \\
\text { All outcomes }\end{array}$ & Low risk & $\begin{array}{l}15 \% \text { attrition at } 12 \text { weeks post-treatment. Balanced across con- } \\
\text { ditions. Reasons addressed. ITT performed. "All outcome anal- } \\
\text { yses were conducted under an intent-to-treat analysis plan on } \\
\text { all subjects who had at least } 1 \text { postrandomization outcome mea- } \\
\text { surement." }\end{array}$ \\
\hline Selective reporting (reporting bias) & Unclear risk & $\begin{array}{l}\text { The published report included all expected outcomes based on } \\
\text { the stated hypotheses. }\end{array}$ \\
\hline
\end{tabular}




\begin{tabular}{|c|c|c|}
\hline Other bias & Low risk & $\begin{array}{l}\text { Used collateral and biological measurement to corroborate self- } \\
\text { reports of substance use. There were no differences between } \\
\text { groups at baseline. No additional sources of bias appear to be } \\
\text { present. }\end{array}$ \\
\hline
\end{tabular}

\section{Ball 2007a}

\begin{tabular}{ll}
\hline Methods & RCT. \\
\hline Participants & Community sample of 98 non-dependent heavy drinking adults from the USA. \\
\hline Interventions & $\begin{array}{l}\text { 1. brief MET }(\mathrm{n}=34) \\
\text { 2. brief coping skills }(\mathrm{n}=35) \\
\text { 3. wait-list control }(\mathrm{n}=29)\end{array}$ \\
\hline
\end{tabular}

\begin{tabular}{ll}
\hline Outcomes & $\begin{array}{l}\text { Physiological primary: Alcohol breath testing. } \\
\text { Non-physiological primary: Frequency of days drinking, amount of drinks per drinking } \\
\text { day. } \\
\text { Secondary: None. }\end{array}$ \\
\hline Notes &
\end{tabular}

\section{Risk of bias}

\begin{tabular}{|c|c|c|}
\hline Bias & Authors' judgement & Support for judgement \\
\hline $\begin{array}{l}\text { Random sequence generation (selection } \\
\text { bias) }\end{array}$ & Unclear risk & $\begin{array}{l}\text { "...participants were randomised to a } 3 \text {-week waiting list control } \\
\text { (WLC) group or one of two manual-guided brief interventions." }\end{array}$ \\
\hline Allocation concealment (selection bias) & Unclear risk & Insufficient information to permit judgement. \\
\hline $\begin{array}{l}\text { Blinding (performance bias and detection } \\
\text { bias) } \\
\text { Patients and providers }\end{array}$ & Low risk & $\begin{array}{l}\text { No blinding, but most outcomes were physiological and also } \\
\text { used to validate self-reports, and not likely to be influenced by } \\
\text { lack of blinding. }\end{array}$ \\
\hline $\begin{array}{l}\text { Blinding (performance bias and detection } \\
\text { bias) } \\
\text { Assessors }\end{array}$ & Low risk & $\begin{array}{l}\text { Insufficient information to know whether assessors were } \\
\text { blinded. But most outcomes were physiological and also used to } \\
\text { validate self-reports, and not likely to be influenced by lack of } \\
\text { blinding. The non-blinding may have caused bias regarding the } \\
\text { interviews, but the hand-held computer assessment is unlikely } \\
\text { to have caused bias. }\end{array}$ \\
\hline $\begin{array}{l}\text { Incomplete outcome data (attrition bias) } \\
\text { All outcomes }\end{array}$ & Low risk & $\begin{array}{l}7 \% \text { attrition at } 3 \text { weeks post-treatment. Balanced across condi- } \\
\text { tions. Used ITT and the non-completers were all accounted for. }\end{array}$ \\
\hline Selective reporting (reporting bias) & Unclear risk & $\begin{array}{l}\text { The published report included all expected outcomes based on } \\
\text { the stated hypotheses. }\end{array}$ \\
\hline
\end{tabular}


Ball 2007a

\begin{tabular}{|c|c|c|}
\hline Other bias & Low risk & $\begin{array}{l}\text { Alcohol breath testing used as check of self-report. Differences } \\
\text { between groups at baseline were not reported. No additional } \\
\text { sources of bias appear to be present. }\end{array}$ \\
\hline
\end{tabular}

\section{Ball 2007b}

\begin{tabular}{ll}
\hline Methods & Multisite RCT $(5$ sites $)$. \\
\hline Participants & 461 outpatients from five outpatient substance abuse programs in the USA. \\
\hline Interventions & MET $(\mathrm{n}=216)$ vs. counselling as usual $(\mathrm{n}=245)$. \\
\hline
\end{tabular}

\begin{tabular}{ll}
\hline Outcomes & $\begin{array}{l}\text { Physiological primary: Urinary drug analysis. } \\
\text { Non-physiological primary: Days per week of primary substance use. } \\
\text { Secondary: Retention in treatment (days enrolled at treatment program, \% enrolled at } \\
\text { program at 4-month follow-up). }\end{array}$ \\
\hline Notes & \\
\hline
\end{tabular}

\section{Risk of bias}

\begin{tabular}{|c|c|c|}
\hline Bias & Authors' judgement & Support for judgement \\
\hline $\begin{array}{l}\text { Random sequence generation (selection } \\
\text { bias) }\end{array}$ & Low risk & $\begin{array}{l}\text { "The randomisation used a computerized program...This } \\
\text { program involved a process of urn allocation". }\end{array}$ \\
\hline Allocation concealment (selection bias) & Unclear risk & $\begin{array}{l}\text { "The randomisation used a computerized program that was } \\
\text { managed by off-site personnel, but accessed locally by a re- } \\
\text { search staff who communicated the assigned therapy condi- } \\
\text { tion". }\end{array}$ \\
\hline $\begin{array}{l}\text { Blinding (performance bias and detection } \\
\text { bias) } \\
\text { Patients and providers }\end{array}$ & Low risk & $\begin{array}{l}\text { No blinding, but most outcomes were physiological and also } \\
\text { used to validate self-reports, and not likely to be influenced } \\
\text { by lack of blinding. }\end{array}$ \\
\hline $\begin{array}{l}\text { Blinding (performance bias and detection } \\
\text { bias) } \\
\text { Assessors }\end{array}$ & Low risk & $\begin{array}{l}\text { Insufficient information to know whether assessors were } \\
\text { blinded. But most outcomes were physiological and also used } \\
\text { to validate self-reports, and not likely to be influenced by lack } \\
\text { of blinding. }\end{array}$ \\
\hline $\begin{array}{l}\text { Incomplete outcome data (attrition bias) } \\
\text { All outcomes }\end{array}$ & Low risk & $\begin{array}{l}32 \% \text { attrition at } 8 \text { weeks post-treatment. } 32 \% \text { attrition at } 16 \\
\text { weeks post-treatment. "There were no significant differences } \\
\text { between therapy conditions or Therapy condition x Program } \\
\text { Site interactions in the rates of follow-up or in the presence or } \\
\text { frequency of missing data points." Reasons for loss-to-follow- } \\
\text { up are not stated. The researchers performed an intention- } \\
\text { to-treat analysis. }\end{array}$ \\
\hline
\end{tabular}


Ball 2007b (Continued)

\begin{tabular}{|c|c|c|}
\hline Selective reporting (reporting bias) & Low risk & $\begin{array}{l}\text { The published report included all expected outcomes based } \\
\text { on the stated hypotheses. }\end{array}$ \\
\hline Other bias & High risk & $\begin{array}{l}\text { Time spent in training was not balanced across conditions. } \\
\text { Some contamination of therapy conditions may have oc- } \\
\text { curred. Differences between groups at baseline were not re- } \\
\text { ported. }\end{array}$ \\
\hline
\end{tabular}

\section{Barnett 2007}

\begin{tabular}{ll}
\hline Methods & RCT. \\
\hline Participants & $\begin{array}{l}\text { 225 US college students referred to attend alcohol education following an alcohol-related } \\
\text { incident. }\end{array}$ \\
\hline Interventions & Brief MI $(\mathrm{n}=112)$ vs. computer-delivered education (Alcohol $101 \mathrm{CD}$ ROM, [n=113]) \\
\hline Outcomes & $\begin{array}{l}\text { Physiological primary: None. } \\
\text { Non-physiological primary: Number of drinking days, number of heavy drinking days, } \\
\text { average number of drinks per drinking day, average estimated BAC, alcohol problems. } \\
\text { Secondary: Motivation to change alcohol use (Contemplation Ladder). }\end{array}$ \\
\hline Notes & \\
\hline
\end{tabular}

\section{Risk of bias}

\begin{tabular}{ll|l}
\hline Bias & Authors' judgement & Support for judgement \\
\hline $\begin{array}{l}\text { Random sequence generation (selection } \\
\text { bias) }\end{array}$ & Low risk & Random numbers table. \\
\hline $\begin{array}{l}\text { Allocation concealment (selection bias) } \\
\text { Unclear risk }\end{array}$ & $\begin{array}{l}\text { "The counsellor opened an envelope containing the baseline } \\
\text { condition assignment, prepared by the project coordinator". It } \\
\text { remains unclear whether envelopes were sequentially numbered, } \\
\text { opaque and sealed. }\end{array}$ \\
\hline
\end{tabular}

Blinding (performance bias and detection High risk

No blinding.

bias)

Patients and providers

Blinding (performance bias and detection Low risk bias)

Assessors

Incomplete outcome data (attrition bias) Unclear risk All outcomes

\begin{abstract}
"A research assistant who was blind to intervention condition conducted the 3-and12-month follow-up assessments in person, or by phone and mail..."
\end{abstract}

$5 \%$ attrition at 3 months follow-up and $6 \%$ attrition at 12 months follow-up with no differences between conditions. Reasons for missing data not stated. ITT not performed. 
Barnett 2007 (Continued)

\begin{tabular}{lll}
\hline Selective reporting (reporting bias) & Low risk & $\begin{array}{l}\text { The published report included all expected outcomes based on } \\
\text { the stated hypotheses. }\end{array}$ \\
\hline Other bias & Unclear risk & $\begin{array}{l}\text { Only self-reported outcomes. There were no differences between } \\
\text { groups at baseline. }\end{array}$ \\
\hline
\end{tabular}

Bazargan-Hejazi 2005

\begin{tabular}{|c|c|c|}
\hline Methods & \multicolumn{2}{|l|}{ Quasi-RCT. } \\
\hline Participants & \multicolumn{2}{|c|}{$\begin{array}{l}295 \text { emergency department patients } 18 \text { years or older who screened positive for at-risk } \\
\text { drinking. USA. }\end{array}$} \\
\hline Interventions & \multicolumn{2}{|c|}{$\begin{array}{l}\text { Brief MI + booster telephone call at } 10 \text { days post enrolment }(n=144) \text { vs usual care }(n= \\
151) .\end{array}$} \\
\hline Outcomes & \multicolumn{2}{|c|}{$\begin{array}{l}\text { Physiological primary: None. } \\
\text { Non-physiological primary: Drinks per drinking day, more than } 6 \text { drinks per occasion } \\
\text { at least weekly, and AUDIT score. } \\
\text { Secondary: None. } \\
\text { Follow-up was } 3 \text { months after enrolment. }\end{array}$} \\
\hline \multicolumn{3}{|l|}{ Notes } \\
\hline \multicolumn{3}{|l|}{ Risk of bias } \\
\hline Bias & Authors' judgement & Support for judgement \\
\hline $\begin{array}{l}\text { Random sequence generation (selection } \\
\text { bias) }\end{array}$ & High risk & $\begin{array}{l}\text { "Each of the } 3 \text { health promotion advocates performed random } \\
\text { allocation for their own enrollees, assigning the first participant } \\
\text { by a flip of a coin, and alternating status thereafter." }\end{array}$ \\
\hline Allocation concealment (selection bias) & High risk & $\begin{array}{l}\text { "Each of the } 3 \text { health promotion advocates performed random } \\
\text { allocation for their own enrollees, assigning the first participant } \\
\text { by a flip of a coin, and alternating status thereafter." }\end{array}$ \\
\hline $\begin{array}{l}\text { Blinding (performance bias and detection } \\
\text { bias) } \\
\text { Patients and providers }\end{array}$ & High risk & No blinding. \\
\hline
\end{tabular}

Blinding (performance bias and detection Low risk bias)

Assessors

\begin{abstract}
"To guard against interviewer bias and to ensure that health promotion advocates were blinded to the patients' randomization allocation for the 3-month follow-up assessments, enrollees were not followed up by the same health promotion advocate who assessed them initially. Patients were notified not to reveal their group assignment to any project staff at any time.”
\end{abstract}


Bazargan-Hejazi 2005 (Continued)

\begin{tabular}{lll}
\hline $\begin{array}{l}\text { Incomplete outcome data (attrition bias) } \\
\text { All outcomes }\end{array}$ & High risk & $\begin{array}{l}37 \% \text { attrition at the } 3 \text { month follow-up, balanced between } \\
\text { groups. Reasons for attrition explained. ITT was not performed. }\end{array}$ \\
\hline Selective reporting (reporting bias) & Low risk & $\begin{array}{l}\text { The published report included all expected outcomes based on } \\
\text { the stated hypotheses. }\end{array}$ \\
\hline Other bias & High risk & $\begin{array}{l}\text { Only self-reported outcomes. The intervention group had a } \\
\text { higher rate of drug use and lower mean age at baseline. }\end{array}$ \\
\hline
\end{tabular}

Bell 2007

\begin{tabular}{ll}
\hline Methods & RCT. \\
\hline Participants & $\begin{array}{l}60 \text { veterans enrolled in substance abuse treatment at the New Mexico Veterans Affairs } \\
\text { Health Care System, USA. }\end{array}$ \\
\hline Interventions & MI + TAU (n=40) vs TAU (n=20). \\
\hline Outcomes & $\begin{array}{l}\text { Physiological primary: None. } \\
\text { Non-physiological primary: Drinks per day, number of drinking days, percent within } \\
\text { safe drinking limits, substance use per day, and number of substance use days. } \\
\text { Secondary: None. } \\
\text { Follow-up was at 2 months. }\end{array}$ \\
\hline Notes & \\
\hline
\end{tabular}

\section{Risk of bias}

\begin{tabular}{|c|c|c|}
\hline Bias & Authors' judgement & Support for judgement \\
\hline $\begin{array}{l}\text { Random sequence generation (selection } \\
\text { bias) }\end{array}$ & Low risk & $\begin{array}{l}\text { "Participants were assigned to condition by a computerized urn } \\
\text { randomisation program which balanced for distribution to the } \\
\text { groups by the following factors: age, education, presence or ab- } \\
\text { sence of history of head injury with loss of consciousness, gen- } \\
\text { der, and enrolment (yes/no) in the six standard treatments..." }\end{array}$ \\
\hline Allocation concealment (selection bias) & Unclear risk & Insufficient information to permit judgement. \\
\hline $\begin{array}{l}\text { Blinding (performance bias and detection } \\
\text { bias) } \\
\text { Patients and providers }\end{array}$ & High risk & No blinding. \\
\hline
\end{tabular}

Blinding (performance bias and detection Unclear risk

It is not stated whether assessors were blinded.

bias)

Assessors 
Bell 2007 (Continued)

\begin{tabular}{|c|c|c|}
\hline $\begin{array}{l}\text { Incomplete outcome data (attrition bias) } \\
\text { All outcomes }\end{array}$ & High risk & $\begin{array}{l}22 \% \text { were lost to follow-up at } 2 \text { months. Not ITT. Reasons for } \\
\text { loss to follow-up stated, but reasons for removal were that they } \\
\text { were disqualified because of lack of baseline drinking }(n=7) \text {. Loss } \\
\text { was balanced. }\end{array}$ \\
\hline Selective reporting (reporting bias) & Low risk & $\begin{array}{l}\text { The published report included all expected outcomes based on } \\
\text { the stated hypotheses. }\end{array}$ \\
\hline Other bias & High risk & Only self-reported outcomes. More females received MI. \\
\hline
\end{tabular}

\section{Bernstein 2009}

\begin{tabular}{ll} 
Methods & Pilot RCT. \\
\hline Participants & $\begin{array}{l}210 \text { patients aged } 14-21 \text { years in an urban, academic paediatric emergency department. } \\
\text { USA. }\end{array}$ \\
\hline Interventions & Brief MI $(\mathrm{n}=68)$ vs assessed control $(\mathrm{n}=71)$ vs non assessed control $(\mathrm{n}=71)$. \\
\hline Outcomes & $\begin{array}{l}\text { Physiological primary: None. } \\
\text { Non-physiological primary: Marijuana consumption including a 30-day self-report of } \\
\text { marijuana use, attempts to quit, cut back, or change conditions of use, and risk factor } \\
\text { questions repeated at follow-up. } \\
\text { Secondary: None. } \\
\text { Follow-up was at } 12 \text { months. }\end{array}$ \\
\hline Notes & $\begin{array}{l}\text { We do not report data on the non assessed control because baseline data on this group } \\
\text { were not reported. }\end{array}$ \\
\hline
\end{tabular}

\section{Risk of bias}

Bias

Random sequence generation (selection Low risk bias)

\section{Authors' judgement Support for judgement}

"Randomization was based on computer-generated random numbers in blocks of 100 stratified by age group (14-17 and 1821 years)."
"A double opaque envelope system enabled blinding of the research assistants who performed the assessment to randomisation status. The first envelope, with randomisation to assessed (Int, AC) or non assessed (NAC) status, was opened immediately after enrolment. A second envelope indicating Int or AC status was not opened until after assessment."
Blinding (performance bias and detection High risk bias)

Patients and providers
No blinding. 
Bernstein 2009 (Continued)

\begin{tabular}{ll|l}
$\begin{array}{l}\text { Blinding (performance bias and detection } \\
\text { bias) } \\
\text { Assessors }\end{array}$ & Low risk & $\begin{array}{l}\text { "Participants were cautioned not to reveal to the research assis- } \\
\text { tants at the time of follow-up whether or not they had received } \\
\text { any further testing after enrolment" }\end{array}$ \\
\hline $\begin{array}{l}\text { Incomplete outcome data (attrition bias) } \\
\text { All outcomes }\end{array}$ & High risk & $\begin{array}{l}30 \% \text { lost to follow-up at } 3 \text { months in the assessed groups, not bal- } \\
\text { anced between groups. } 29 \% \text { lost to follow-up at twelve months } \\
\text { across all groups, not balanced across groups. Reasons for loss } \\
\text { not stated. Not ITT, but worst-case scenario analysis. }\end{array}$ \\
\hline Selective reporting (reporting bias) & Low risk & $\begin{array}{l}\text { The published report included all expected outcomes based on } \\
\text { the stated hypotheses. }\end{array}$ \\
\hline Other bias & High risk & $\begin{array}{l}\text { Only self-reported outcomes. The intervention group used mar- } \\
\text { ijuana on more days per month than the AC group at baseline. }\end{array}$
\end{tabular}

Bien 1993

\begin{tabular}{ll}
\hline Methods & RCT. \\
\hline Participants & 32 US outpatients from VA outpatient substance abuse treatment program. \\
\hline Interventions & $\begin{array}{l}\text { Brief MI }+ \text { standard outpatient treatment }(\mathrm{n}=16) \text { vs. attention placebo interview }+ \\
\text { standard outpatient treatment }(\mathrm{n}=16) .\end{array}$
\end{tabular}

Outcomes

Physiological primary: None.

Non-physiological primary: SEC (standard drink units), BAL, percent days abstinent.

Secondary: VA treatment attendance.

Notes

Risk of bias

\begin{tabular}{lll}
\hline Bias & Authors judgement & Support for judgement \\
\hline $\begin{array}{l}\text { Random sequence generation (selection } \\
\text { bias) }\end{array}$ & Unclear risk & $\begin{array}{l}\text { “...half were assigned at random to receive a motivational inter- } \\
\text { view, while the rest served as a control group.” }\end{array}$ \\
\hline $\begin{array}{l}\text { Allocation concealment (selection bias) } \\
\text { Blinding (performance bias and detection } \\
\text { bias) } \\
\text { Patients and providers }\end{array}$ & Unclear risk & $\begin{array}{l}\text { “..the experimenter opened a sealed envelope...” It is not stated } \\
\text { whether the envelopes were sequentially numbered or opaque. }\end{array}$ \\
\hline
\end{tabular}

Blinding (performance bias and detection Low risk bias)

Assessors 
Bien 1993 (Continued)

\begin{tabular}{lll}
\hline $\begin{array}{l}\text { Incomplete outcome data (attrition bias) } \\
\text { All outcomes }\end{array}$ & Unclear risk & $\begin{array}{l}19 \% \text { attrition at } 6 \text { months follow-up, balanced between groups. } \\
\text { Reasons for attrition explained. Unclear whether ITT was per- } \\
\text { formed. }\end{array}$ \\
\hline Selective reporting (reporting bias) & Low risk & $\begin{array}{l}\text { The published report included all expected outcomes based on } \\
\text { the stated hypotheses. }\end{array}$ \\
\hline Other bias & Low risk & $\begin{array}{l}\text { Collateral report as check of self-report. There were no differ- } \\
\text { ences between groups at baseline. No additional sources of bias } \\
\text { appear to be present. }\end{array}$ \\
\hline
\end{tabular}

\section{Borsari 2005}

\begin{tabular}{|c|c|c|}
\hline Methods & \multicolumn{2}{|l|}{ Multisite RCT (2 sites). } \\
\hline Participants & \multicolumn{2}{|c|}{64 US students mandated to a substance use prevention program. } \\
\hline Interventions & \multicolumn{2}{|c|}{ Brief MI $(n=34)$ vs. alcohol education session $(n=30)$. } \\
\hline Outcomes & \multicolumn{2}{|c|}{$\begin{array}{l}\text { Physiological primary: None. } \\
\text { Non-physiological primary: Drinks per week, binge drinking episodes, typical BAC, } \\
\text { peak BAC, RAPI. } \\
\text { Secondary: None. }\end{array}$} \\
\hline \multicolumn{3}{|l|}{ Notes } \\
\hline \multicolumn{3}{|l|}{ Risk of bias } \\
\hline Bias & Authors' judgement & Support for judgement \\
\hline $\begin{array}{l}\text { Random sequence generation (selection } \\
\text { bias) }\end{array}$ & Unclear risk & "Randomly assigned". \\
\hline Allocation concealment (selection bias) & Unclear risk & Insufficient information to permit judgment. \\
\hline $\begin{array}{l}\text { Blinding (performance bias and detection } \\
\text { bias) } \\
\text { Patients and providers }\end{array}$ & High risk & No blinding. \\
\hline $\begin{array}{l}\text { Blinding (performance bias and detection } \\
\text { bias) } \\
\text { Assessors }\end{array}$ & Unclear risk & It is not stated whether the assessors were blinded. \\
\hline $\begin{array}{l}\text { Incomplete outcome data (attrition bias) } \\
\text { All outcomes }\end{array}$ & High risk & $\begin{array}{l}11 \% \text { loss-to-follow-up after } 3 \text { months and } 25 \% \text { lost to follow- } \\
\text { up after } 6 \text { months. Balance in numbers not stated. Reasons } \\
\text { for missing data not stated. ITT not performed. }\end{array}$ \\
\hline
\end{tabular}


Borsari 2005 (Continued)

\begin{tabular}{|c|c|c|}
\hline Selective reporting (reporting bias) & Low risk & $\begin{array}{l}\text { The published report included all expected outcomes based } \\
\text { on the stated hypotheses. }\end{array}$ \\
\hline Other bias & Unclear risk & $\begin{array}{l}\text { Collateral report as check of self-report. There were baseline } \\
\text { differences in AUDIT, typical BAC, and number of drinks } \\
\text { per week. }\end{array}$ \\
\hline
\end{tabular}

\section{Brown 2010}

\begin{tabular}{ll}
\hline Methods & RCT. \\
\hline Participants & $\begin{array}{l}184 \text { men and women who had been driving while impaired (DWI) with drinking prob- } \\
\text { lems, who were recidivists, and who were not currently engaged in DWI interventions. } \\
\text { Canada. }\end{array}$ \\
\hline Interventions & Brief MI (n= 92) vs. information-advice (n= 92). \\
\hline Outcomes & $\begin{array}{l}\text { Physiological primary: Biomarkers of alcohol abuse (GGT, AST, ALT, MCV) by blood } \\
\text { assay. } \\
\text { Non-physiological primary: Alcohol abuse-related behaviours (percent risky drinking } \\
\text { days) using the MMPI-Mac Scale. } \\
\text { Secondary: Subsequent substance abuse treatment service utilization (data not reported) } \\
\text { Readiness to change. }\end{array}$ \\
\hline Notes & \\
\hline
\end{tabular}

\section{Risk of bias}

Bias Authors' judgement Support for judgement

Random sequence generation (selection Low risk Computerized urn randomisation. bias)

\begin{tabular}{lll} 
Allocation concealment (selection bias) & Unclear risk & Not described. \\
\hline $\begin{array}{l}\text { Blinding (performance bias and detection } \\
\text { bias) }\end{array}$ & Low risk & $\begin{array}{l}\text { "Participants, interviewers who administered the baseline and } \\
\text { Patients and providers }\end{array}$ \\
& & $\begin{array}{l}\text { follow-up assessments, the statistician who conducted the initial } \\
\text { analyses to test the main hypotheses, and investigators were blind } \\
\text { to participant assignment." }\end{array}$ \\
\hline
\end{tabular}

Blinding (performance bias and detection Low risk bias)

Assessors
"Participants, interviewers who administered the baseline and follow-up assessments, the statistician who conducted the initial analyses to test the main hypotheses, and investigators were blind to participant assignment." 
Brown 2010 (Continued)

\begin{tabular}{l|ll}
$\begin{array}{l}\text { Incomplete outcome data (attrition bias) } \\
\text { All outcomes }\end{array}$ & Low risk & $\begin{array}{l}7 \% \text { were lost after randomisation and intervention. They were } \\
\text { excluded from further analyses (not intention to treat). No rea- } \\
\text { sons for attrition. A further 6\% were lost and data were esti- } \\
\text { mated. }\end{array}$ \\
\hline Selective reporting (reporting bias) & Low risk & $\begin{array}{l}\text { The published report included all expected outcomes based on } \\
\text { the stated hypotheses. }\end{array}$ \\
\hline Other bias & Low risk & $\begin{array}{l}\text { Threat of invalidity in self-report was addressed by corrobora- } \\
\text { tion from bio markers and measurement of social desirability } \\
\text { in response styles. There were no differences between groups at } \\
\text { baseline. }\end{array}$ \\
\hline
\end{tabular}

\section{Carey 2006}

\begin{tabular}{ll}
\hline Methods & RCT. \\
\hline Participants & 509 US heavy drinking students. \\
\hline Interventions & 1. Timeline Follow-Back control $(\mathrm{n}=89)$ \\
& $\begin{array}{l}\text { 2. TLFB basic MI }(\mathrm{n}=87) \\
\text { 3. TLFB enhanced MI }(\mathrm{n}=86) \\
\text { 4. control }(\mathrm{n}=81) \\
\text { 5. basic BMI }(\mathrm{n}=85) \\
\text { 6. enhanced BMI }(\mathrm{n}=81) .\end{array}$ \\
\hline
\end{tabular}

Outcomes

Physiological primary: None.

Non-physiological primary: Drinks per week, drinking per drinking day, heavy drinking frequency, peak BAC, RAPI score.

Secondary: None.

Notes

Risk of bias

Bias

Authors' judgement Support for judgement

Random sequence generation (selection Unclear risk "Assigned randomly". bias)

\begin{tabular}{llll}
\hline Allocation concealment (selection bias) & Unclear risk & Insufficient information to permit judgment. \\
\hline $\begin{array}{l}\text { Blinding (performance bias and detection } \\
\text { bias) }\end{array}$ & High risk & No blinding. \\
$\begin{array}{l}\text { Patients and providers } \\
\text { M }\end{array}$ & \\
\hline
\end{tabular}


Carey 2006 (Continued)

\begin{tabular}{ll|l}
\hline $\begin{array}{l}\text { Blinding (performance bias and detection } \\
\text { bias) } \\
\text { Assessors }\end{array}$ & High risk & Assessors "were not blind to condition." \\
\hline $\begin{array}{l}\text { Incomplete outcome data (attrition bias) } \\
\text { All outcomes }\end{array}$ & Unclear risk & $\begin{array}{l}3 \% \text { lost to follow-up at one month, 23\% at } 6 \text { months and } 22 \% \\
\text { at } 12 \text { months. Balanced across conditions. Reasons for missing } \\
\text { data addressed but not detailed. Unclear whether ITT was used. }\end{array}$ \\
\hline Selective reporting (reporting bias) & Low risk & $\begin{array}{l}\text { The published report included all expected outcomes based on } \\
\text { the stated hypotheses. }\end{array}$ \\
\hline Other bias & Low risk & $\begin{array}{l}\text { Collateral report as check of self-report. There were no differ- } \\
\text { ences between groups at baseline. No additional sources of bias } \\
\text { appear to be present. }\end{array}$ \\
\hline
\end{tabular}

\section{Carroll 2006a}

\begin{tabular}{ll}
\hline Methods & Multisite RCT $(5$ sites $)$. \\
\hline Participants & $\begin{array}{l}\text { 423 US substance users entering outpatient treatment in five community-based treatment } \\
\text { settings. }\end{array}$ \\
\hline Interventions & MI + standard intake evaluation $(\mathrm{n}=173)$ vs standard intake evaluation $(\mathrm{n}=178)$. \\
\hline Outcomes & $\begin{array}{l}\text { Physiological primary: Urine test }+ \text { breath test. } \\
\text { Non-physiological primary: Days of use of primary substance. } \\
\text { Secondary: Readiness for change (URICA [data not reported]). } \\
\text { Retention in treatment (percent retained at site, number of sessions completed). }\end{array}$ \\
\hline Notes & \\
\hline
\end{tabular}

\section{Risk of bias}

\begin{tabular}{|c|c|c|}
\hline Bias & Authors' judgement & Support for judgement \\
\hline $\begin{array}{l}\text { Random sequence generation (selection } \\
\text { bias) }\end{array}$ & Low risk & $\begin{array}{l}\text { "...participants were randomised to condition (MI or stan- } \\
\text { dard evaluation) using an urn randomisation." }\end{array}$ \\
\hline Allocation concealment (selection bias) & Unclear risk & Insufficient information to permit judgment. \\
\hline $\begin{array}{l}\text { Blinding (performance bias and detection } \\
\text { bias) } \\
\text { Patients and providers }\end{array}$ & Low risk & $\begin{array}{l}\text { No blinding, but most outcomes were physiological and also } \\
\text { used to validate self-reports, and not likely to be influenced } \\
\text { by lack of blinding. }\end{array}$ \\
\hline $\begin{array}{l}\text { Blinding (performance bias and detection } \\
\text { bias) } \\
\text { Assessors }\end{array}$ & Unclear risk & $\begin{array}{l}\text { Insufficient information to know whether assessors were } \\
\text { blinded. But most outcomes were physiological and also used } \\
\text { to validate self-reports, and not likely to be influenced by lack } \\
\text { of blinding. }\end{array}$ \\
\hline
\end{tabular}




\section{Carroll 2006a (Continued)}

\begin{tabular}{|c|c|c|}
\hline $\begin{array}{l}\text { Incomplete outcome data (attrition bias) } \\
\text { All outcomes }\end{array}$ & High risk & $\begin{array}{l}24 \% \text { attrition at one month, } 27 \% \text { attrition at } 3 \text { months bal- } \\
\text { anced by condition. No reasons for attrition reported. ITT } \\
\text { not done. }\end{array}$ \\
\hline Selective reporting (reporting bias) & Low risk & $\begin{array}{l}\text { The published report included all expected outcomes based } \\
\text { on the stated hypotheses. }\end{array}$ \\
\hline Other bias & Unclear risk & $\begin{array}{l}\text { Urine and breath samples to check on self-report. Time spent } \\
\text { in training was not balanced across conditions, and clinicians } \\
\text { assigned to MI received more training and supervision. There } \\
\text { were no differences between groups at baseline. }\end{array}$ \\
\hline
\end{tabular}

\section{Carroll 2006b}

\begin{tabular}{ll}
\hline Methods & RCT. \\
\hline Participants & 136 US marijuana-dependent young adults referred by the criminal justice system. \\
\hline Interventions & $\begin{array}{l}\text { 1. MET/contingency management }(\mathrm{n}=33) \\
\text { 2. drug counselling/contingency management }(\mathrm{n}=34) \\
\text { 3. MET ( } \mathrm{n}=35) \\
\text { 4. drug counselling }(\mathrm{n}=33) .\end{array}$ \\
\hline
\end{tabular}

Outcomes

Physiological primary: Marijuana positive urine specimens (\%).

Non-physiological primary: Days of marijuana use (\%), longest duration of continuous abstinence,

Secondary: None.

Notes

\section{Risk of bias}

\begin{tabular}{|c|c|c|}
\hline Bias & Authors' judgement & Support for judgement \\
\hline $\begin{array}{l}\text { Random sequence generation (selection } \\
\text { bias) }\end{array}$ & Unclear risk & "...were randomised to one of the four treatment conditions" \\
\hline Allocation concealment (selection bias) & Unclear risk & Insufficient information to permit judgment. \\
\hline $\begin{array}{l}\text { Blinding (performance bias and detection } \\
\text { bias) } \\
\text { Patients and providers }\end{array}$ & Low risk & $\begin{array}{l}\text { No blinding, but most outcomes were physiological and also } \\
\text { used to validate self-reports, and not likely to be influenced by } \\
\text { lack of blinding. }\end{array}$ \\
\hline $\begin{array}{l}\text { Blinding (performance bias and detection } \\
\text { bias) } \\
\text { Assessors }\end{array}$ & Low risk & $\begin{array}{l}\text { Insufficient information to know whether assessors were } \\
\text { blinded. But most outcomes were physiological and also used to } \\
\text { validate self-reports, and not likely to be influenced by lack of } \\
\text { blinding. }\end{array}$ \\
\hline
\end{tabular}


Carroll 2006b (Continued)

\begin{tabular}{|c|c|c|}
\hline $\begin{array}{l}\text { Incomplete outcome data (attrition bias) } \\
\text { All outcomes }\end{array}$ & Unclear risk & $\begin{array}{l}38 \% \text { attrition at } 3 \text { months and } 21 \% \text { attrition at } 6 \text { months. Im- } \\
\text { balance between groups. Reasons for missing data not stated. } \\
\text { ITT was performed. }\end{array}$ \\
\hline Selective reporting (reporting bias) & Low risk & $\begin{array}{l}\text { The published report included all expected outcomes based on } \\
\text { the stated hypotheses. }\end{array}$ \\
\hline Other bias & Low risk & $\begin{array}{l}\text { Urine toxicology screens and breath samples to check on self- } \\
\text { report. There were no differences between groups at baseline. } \\
\text { No additional sources of bias appear to be present. }\end{array}$ \\
\hline
\end{tabular}

\section{Carroll 2009}

\begin{tabular}{|c|c|}
\hline Methods & Multisite RCT (5 sites) in the USA. \\
\hline Participants & 436 Hispanic substance abusers from the USA. \\
\hline Interventions & MET $(n=214)$ vs counselling as usual $(n=222)$. \\
\hline Outcomes & $\begin{array}{l}\text { Physiological primary: Percent positive urine specimens. } \\
\text { Non-physiological primary: Days of substance use by week, percent days abstinent } \\
\text { from alcohol. } \\
\text { Secondary: Treatment retention (days enrolled in treatment at community treatment } \\
\text { program through week 16). }\end{array}$ \\
\hline Notes & The design paralleled that of Ball 2007b. \\
\hline
\end{tabular}

\section{Risk of bias}

\begin{tabular}{lll}
\hline Bias & Authors' judgement & Support for judgement \\
\hline $\begin{array}{l}\text { Random sequence generation (selection } \\
\text { bias) }\end{array}$ & Low risk & Urn allocation. \\
\hline $\begin{array}{l}\text { Allocation concealment (selection bias) } \\
\text { Blinding (performance bias and detection } \\
\text { bias) } \\
\text { Patients and providers }\end{array}$ & Low risk & Insufficient information to permit judgement. \\
\hline $\begin{array}{l}\text { Blinding (performance bias and detection } \\
\text { bias) } \\
\text { Assessors }\end{array}$ & Low risk & $\begin{array}{l}\text { No blinding, but most outcomes were physiolog- } \\
\text { ical and also used to validate self-reports, and not } \\
\text { likely to be influenced by lack of blinding. }\end{array}$ \\
\hline
\end{tabular}


Carroll 2009 (Continued)

\begin{tabular}{|c|c|c|}
\hline $\begin{array}{l}\text { Incomplete outcome data (attrition bias) } \\
\text { All outcomes }\end{array}$ & High risk & $\begin{array}{l}28 \% \text { lost to follow-up. Reasons for attrition not } \\
\text { described but similar between groups. Not ITT } \\
\text { even though they reported an intention to treat } \\
\text { sample. }\end{array}$ \\
\hline Selective reporting (reporting bias) & Low risk & $\begin{array}{l}\text { The published report included all expected out- } \\
\text { comes based on the stated hypotheses. }\end{array}$ \\
\hline Other bias & Unclear risk & $\begin{array}{l}\text { Only self-reported outcomes. Differences at base- } \\
\text { line were not reported. }\end{array}$ \\
\hline
\end{tabular}

Chanut 2007

\begin{tabular}{ll}
\hline Methods & Pilot RCT. \\
\hline Participants & 51 offenders convicted of driving under the influence (DUI). Canada. \\
\hline Interventions & MI $(\mathrm{n}=24)$ vs psycho-education $(\mathrm{n}=27)$. \\
\hline Outcomes & $\begin{array}{l}\text { Physiological primary: None. } \\
\text { Non-physiological primary: Heavy drinking days }(>6 \text { units/day) and AUDIT. } \\
\text { Secondary: Service utilization. } \\
\text { Follow-ups were at } 3 \text { months and } 6 \text { months. }\end{array}$ \\
\hline Notes & \\
\hline
\end{tabular}

\section{Risk of bias}

\begin{tabular}{|c|c|c|}
\hline Bias & Authors' judgement & Support for judgement \\
\hline $\begin{array}{l}\text { Random sequence generation (selection } \\
\text { bias) }\end{array}$ & Low risk & $\begin{array}{l}\text { Urn randomisation ("Un protocole de randomisation par urnes } \\
\text { assisté par ordinateur (Project MATCH Research Group, 1993) } \\
\text { a été utilisé pour assigner les participants à l'une des deux con- } \\
\text { ditions."). }\end{array}$ \\
\hline Allocation concealment (selection bias) & Unclear risk & Insufficient information to permit judgement. \\
\hline $\begin{array}{l}\text { Blinding (performance bias and detection } \\
\text { bias) } \\
\text { Patients and providers }\end{array}$ & Unclear risk & $\begin{array}{l}\text { Blinding of providers was not possible, but participants could } \\
\text { have been blinded. }\end{array}$ \\
\hline $\begin{array}{l}\text { Blinding (performance bias and detection } \\
\text { bias) } \\
\text { Assessors }\end{array}$ & Unclear risk & It is not stated whether assessors were blinded. \\
\hline $\begin{array}{l}\text { Incomplete outcome data (attrition bias) } \\
\text { All outcomes }\end{array}$ & Unclear risk & $\begin{array}{l}\text { Attrition was } 22 \% \text { at } 3 \text { months and } 29 \% \text { at } 6 \text { months. Balanced } \\
\text { across groups. Reasons for loss to follow-up not reported. Use of }\end{array}$ \\
\hline
\end{tabular}


Chanut 2007 (Continued)

ITT was reported but it is unclear whether all reported analyses used ITT.

\begin{tabular}{|c|c|c|}
\hline Selective reporting (reporting bias) & Low risk & $\begin{array}{l}\text { The published report included all expected outcomes based on } \\
\text { the stated hypotheses. }\end{array}$ \\
\hline Other bias & Unclear risk & $\begin{array}{l}\text { Used collaterals to verify self-report. There were baseline differ- } \\
\text { ences in days of hazardous drinking and the Drug Abuse Screen- } \\
\text { ing Test. }\end{array}$ \\
\hline
\end{tabular}

Connors 2002

\begin{tabular}{ll}
\hline Methods & RCT. \\
\hline Participants & 126 US clients entering outpatient alcoholism treatment. \\
\hline Interventions & $\begin{array}{l}\text { MI }(\mathrm{n}=40) \text { vs Role induction }(\mathrm{n}=37) \text { vs non-preparatory session control group ( } \mathrm{n}= \\
\text { Outcomes }\end{array}$ \\
\hline $\begin{array}{l}\text { Physiological primary: None. } \\
\text { Non-physiological primary: Abstinent days, heavy drinking days. } \\
\text { Secondary: Retention in treatment (therapy session attendance). }\end{array}$ \\
\hline Notes & \\
\hline
\end{tabular}

Risk of bias

\section{Bias}

Authors' judgement Support for judgement

Random sequence generation (selection Unclear risk bias)

"Clients were randomly assigned to one of three preparatory intervention conditions".

\begin{tabular}{lll}
\hline Allocation concealment (selection bias) & Unclear risk & Insufficient information to permit judgment. \\
\hline $\begin{array}{l}\text { Blinding (performance bias and detection } \\
\text { bias) }\end{array}$ & Unclear risk & $\begin{array}{l}\text { Blinding of providers was not possible, but participants could } \\
\text { have been blinded. }\end{array}$ \\
\hline
\end{tabular}

Patients and providers

Blinding (performance bias and detection Unclear risk

It is not stated whether the assessors were blinded.

bias)

Assessors

\begin{tabular}{|c|c|c|}
\hline $\begin{array}{l}\text { Incomplete outcome data (attrition bias) } \\
\text { All outcomes }\end{array}$ & Unclear risk & $\begin{array}{l}13(10 \%) \text { did not provide Timeline Follow-Back Interview data } \\
\text { at the } 12 \text { month point. Of these } 13,12 \text { actively withdrew from } \\
\text { the study or ceased cooperation with follow-up efforts and } 1 \\
\text { moved and could not be located. We do not know the attrition } \\
\text { for the post-treatment and the } 3,6 \text {, and } 9 \text { month follow-ups. } \\
\text { Balance between conditions was not stated and ITT was not }\end{array}$ \\
\hline
\end{tabular}


Connors 2002 (Continued)

performed.

\begin{tabular}{|c|c|c|}
\hline Selective reporting (reporting bias) & Low risk & $\begin{array}{l}\text { The published report included all expected outcomes based on } \\
\text { the study purposes. }\end{array}$ \\
\hline Other bias & Low risk & $\begin{array}{l}\text { Collateral report to check on self-report. There were no differ- } \\
\text { ences between groups at baseline. No additional sources of bias } \\
\text { appear to be present. }\end{array}$ \\
\hline
\end{tabular}

Copeland 2001

\begin{tabular}{ll}
\hline Methods & RCT. \\
\hline Participants & 229 Australian cannabis users. \\
\hline Interventions & $\begin{array}{l}\text { 1. } 6 \text {-session CBT (including elements of MI) }(\mathrm{n}=78) \\
\text { 2. } 1 \text {-session CBT (including elements of MI) }(\mathrm{n}=82) \\
\text { 3. delayed treatment control group }(\mathrm{n}=69) .\end{array}$ \\
\hline
\end{tabular}

\begin{tabular}{ll}
\hline Outcomes & Physiological primary: None. \\
& Non-physiological primary: Daily amount of cannabis use in last month, cannabis \\
dependence, proportion of cannabis related problems. & Secondary: None. \\
\hline
\end{tabular}

Notes

Risk of bias

\begin{tabular}{|c|c|c|}
\hline Bias & Authors' judgement & Support for judgement \\
\hline $\begin{array}{l}\text { Random sequence generation (selection } \\
\text { bias) }\end{array}$ & Unclear risk & “...randomised to one of three conditions". \\
\hline Allocation concealment (selection bias) & Unclear risk & Insufficient information to permit judgment. \\
\hline $\begin{array}{l}\text { Blinding (performance bias and detection } \\
\text { bias) } \\
\text { Patients and providers }\end{array}$ & Unclear risk & $\begin{array}{l}\text { No blinding but the outcome measurements are not likely to be } \\
\text { influenced by lack of blinding due to validation with physiolog- } \\
\text { ical measurement. }\end{array}$ \\
\hline $\begin{array}{l}\text { Blinding (performance bias and detection } \\
\text { bias) } \\
\text { Assessors }\end{array}$ & Low risk & $\begin{array}{l}\text { "...follow-up was conducted by an independent researcher } \\
\text { "blind" to the subject's treatment allocation." }\end{array}$ \\
\hline $\begin{array}{l}\text { Incomplete outcome data (attrition bias) } \\
\text { All outcomes }\end{array}$ & High risk & $\begin{array}{l}26 \% \text { attrition at a median of } 237 \text { days follow-up (individual fol- } \\
\text { low-up durations, range: } 102-553 \text { days). Drop out was balanced } \\
\text { across groups. No reasons for drop-out were stated. "Analyses } \\
\text { were conducted on an intention-to-treat basis." A best-case sce- } \\
\text { nario was reported. }\end{array}$ \\
\hline
\end{tabular}


Copeland 2001 (Continued)

\begin{tabular}{|c|c|c|}
\hline Selective reporting (reporting bias) & Low risk & $\begin{array}{l}\text { The published report included all expected outcomes based on } \\
\text { the study purposes. }\end{array}$ \\
\hline Other bias & High risk & $\begin{array}{l}17 \% \text { had sought assistance to moderate their use in the time be- } \\
\text { tween their participation in this study and follow-up. They used } \\
\text { urinalysis of cannabinoid levels as a validation of self-reported } \\
\text { cannabis use. Differences between groups at baseline were not } \\
\text { reported. }\end{array}$ \\
\hline
\end{tabular}

D'Amico 2008

\begin{tabular}{ll}
\hline Methods & Pilot RCT. \\
\hline Participants & $\begin{array}{l}64 \text { high-risk teens in a primary care clinic that provides health care for underserved } \\
\text { populations. USA. }\end{array}$ \\
\hline Interventions & 15 minutes of MI $(\mathrm{n}=38)$ or usual care $(\mathrm{n}=26)$.
\end{tabular}

\begin{tabular}{ll} 
Outcomes & $\begin{array}{l}\text { Physiological primary: None. } \\
\text { Non-physiological primary: Number of days last month drank alcohol. Number of } \\
\text { times used marijuana on days used. Number of alcoholic drinks consumed on days drink- } \\
\text { ing. Number of days consumed more than } 3 \text { drinks. Number of days used marijuana. } \\
\text { Secondary: None. }\end{array}$ \\
\hline Notes & Project CHAT. \\
\hline
\end{tabular}

Risk of bias

\begin{tabular}{|c|c|c|}
\hline Bias & Authors' judgement & Support for judgement \\
\hline $\begin{array}{l}\text { Random sequence generation (selection } \\
\text { bias) }\end{array}$ & Unclear risk & Insufficient information to permit judgement. \\
\hline Allocation concealment (selection bias) & Unclear risk & Insufficient information to permit judgement. \\
\hline $\begin{array}{l}\text { Blinding (performance bias and detection } \\
\text { bias) } \\
\text { Patients and providers }\end{array}$ & High risk & No blinding. \\
\hline $\begin{array}{l}\text { Blinding (performance bias and detection } \\
\text { bias) } \\
\text { Assessors }\end{array}$ & Unclear risk & Mailed questionnaire used for follow up. \\
\hline $\begin{array}{l}\text { Incomplete outcome data (attrition bias) } \\
\text { All outcomes }\end{array}$ & High risk & $\begin{array}{l}34 \% \text { of those randomised did not complete the final survey } \\
\text { (unequal numbers). } 8 \text { participants did not want to participate, } \\
\text { but the rest could not be reached. No ITT. }\end{array}$ \\
\hline
\end{tabular}


D’Amico 2008 (Continued)

\begin{tabular}{|c|c|c|}
\hline Selective reporting (reporting bias) & Low risk & $\begin{array}{l}\text { The published report included all expected outcomes based on } \\
\text { the stated hypotheses. }\end{array}$ \\
\hline Other bias & Unclear risk & $\begin{array}{l}\text { Only self-reported outcomes. Differences between groups at } \\
\text { baseline were not reported. }\end{array}$ \\
\hline
\end{tabular}

De Wildt 2002

\begin{tabular}{ll}
\hline Methods & Multisite RCT (14 sites). \\
\hline Participants & 248 Dutch patients meeting DSM-IV criteria for alcohol dependence or abuse. \\
\hline Interventions & $\begin{array}{l}\text { 1. Acamprosate + MET }(\mathrm{n}=86) \\
\text { 2. Acamprosate }+ \text { CBT }(\mathrm{n}=78) \\
\text { 3. Acamprosate }(\mathrm{n}=77) .\end{array}$ \\
\hline Outcomes & $\begin{array}{l}\text { Physiological primary: GGT. } \\
\text { Non-physiological primary: Number abstinent, number relapsed, time to first relapse, } \\
\text { number of abstinent days, rate of continuous abstinence. } \\
\text { Secondary: None. }\end{array}$ \\
\hline Notes & \\
\hline
\end{tabular}

Risk of bias

\begin{tabular}{|c|c|c|}
\hline Bias & Authors' judgement & Support for judgement \\
\hline $\begin{array}{l}\text { Random sequence generation (selection } \\
\text { bias) }\end{array}$ & Unclear risk & $\begin{array}{l}\text { "Sealed envelope randomisation with balancing by blocks } \\
\text { of } 15 \text { was used to obtain equal numbers of patients per } \\
\text { treatment group from each centre." }\end{array}$ \\
\hline Allocation concealment (selection bias) & Unclear risk & Insufficient information to permit judgment. \\
\hline $\begin{array}{l}\text { Blinding (performance bias and detection } \\
\text { bias) } \\
\text { Patients and providers }\end{array}$ & Low risk & $\begin{array}{l}\text { No blinding, but most outcomes were physiological and also } \\
\text { used to validate self-reports, and not likely to be influenced } \\
\text { by lack of blinding. }\end{array}$ \\
\hline $\begin{array}{l}\text { Blinding (performance bias and detection } \\
\text { bias) } \\
\text { Assessors }\end{array}$ & Low risk & $\begin{array}{l}\text { Insufficient information to know whether assessors were } \\
\text { blinded. But most outcomes were physiological and also } \\
\text { used to validate self-reports, and not likely to be influenced } \\
\text { by lack of blinding. }\end{array}$ \\
\hline $\begin{array}{l}\text { Incomplete outcome data (attrition bias) } \\
\text { All outcomes }\end{array}$ & Low risk & $\begin{array}{l}30 \% \text { attrition at } 6 \text { months follow-up. Balanced drop-out } \\
\text { and reasons for drop-out stated. ITT completed. }\end{array}$ \\
\hline Selective reporting (reporting bias) & Low risk & $\begin{array}{l}\text { The published report included all expected outcomes based } \\
\text { on the study hypotheses. }\end{array}$ \\
\hline
\end{tabular}


De Wildt 2002 (Continued)

\begin{tabular}{l|l}
\hline Other bias & $\begin{array}{l}\text { 23\% of patients consulted some other professional for alco- } \\
\text { hol-related problems during the treatment. Blood samples } \\
\text { were drawn to check on self-report. There were no differ- } \\
\text { ences between groups at baseline. }\end{array}$ \\
\hline
\end{tabular}

Emmen 2005

\begin{tabular}{ll}
\hline Methods & RCT. \\
\hline Participants & 123 Dutch patients who visited an outpatient clinic for problem drinking. \\
\hline Interventions & Dutch version of Drinker's Checkup ( $\mathrm{n}=61)$ vs care as usual $(\mathrm{n}=62)$. \\
\hline Outcomes & $\begin{array}{l}\text { Physiological primary: Serum carbohydrate-deficient transferrin. } \\
\text { Non-physiological primary: Units per day in previous six months. } \\
\text { Secondary: Motivation to change. }\end{array}$ \\
\hline Notes & \\
\hline
\end{tabular}

Risk of bias

\begin{tabular}{|c|c|c|}
\hline Bias & Authors' judgement & Support for judgement \\
\hline $\begin{array}{l}\text { Random sequence generation (selection } \\
\text { bias) }\end{array}$ & Low risk & $\begin{array}{l}\text { "...balanced block randomisation. The main researcher (M.J.E) } \\
\text { used sealed envelopes to generate the allocation sequence." }\end{array}$ \\
\hline Allocation concealment (selection bias) & Unclear risk & Insufficient information to permit judgment. \\
\hline $\begin{array}{l}\text { Blinding (performance bias and detection } \\
\text { bias) } \\
\text { Patients and providers }\end{array}$ & Low risk & $\begin{array}{l}\text { No blinding, but most outcomes were physiological and also } \\
\text { used to validate self-reports, and not likely to be influenced by } \\
\text { lack of blinding. }\end{array}$ \\
\hline $\begin{array}{l}\text { Blinding (performance bias and detection } \\
\text { bias) } \\
\text { Assessors }\end{array}$ & Low risk & $\begin{array}{l}\text { Not blinded, but most outcomes were physiological and also } \\
\text { used to validate self-reports, and not likely to be influenced by } \\
\text { lack of blinding. }\end{array}$ \\
\hline $\begin{array}{l}\text { Incomplete outcome data (attrition bias) } \\
\text { All outcomes }\end{array}$ & Low risk & $\begin{array}{l}\text { 9\% lost-to-follow-up at } 6 \text { months. Balanced drop-out. Reasons } \\
\text { stated. ITT performed. }\end{array}$ \\
\hline Selective reporting (reporting bias) & Low risk & $\begin{array}{l}\text { The published report included all expected outcomes based on } \\
\text { the study hypotheses. }\end{array}$ \\
\hline Other bias & Low risk & $\begin{array}{l}\text { Serum carbohydrate-deficient transferrin (CDT) was measured } \\
\text { (biological data). There were no differences between groups at } \\
\text { baseline. No additional sources of bias appear to be present. }\end{array}$ \\
\hline
\end{tabular}


Feldstein 2007

\begin{tabular}{|c|c|c|}
\hline Methods & \multicolumn{2}{|l|}{ RCT. } \\
\hline Participants & \multicolumn{2}{|c|}{55 US under aged heavy drinkers. } \\
\hline Interventions & \multicolumn{2}{|c|}{1 session MI $(n=40)$ vs no treatment control $(n=15)$. } \\
\hline Outcomes & \multicolumn{2}{|c|}{$\begin{array}{l}\text { Physiological primary: None. } \\
\text { Non-physiological primary: Binge drinking last } 2 \text { weeks, RAPI. } \\
\text { Secondary: None. }\end{array}$} \\
\hline \multicolumn{3}{|l|}{ Notes } \\
\hline \multicolumn{3}{|l|}{ Risk of bias } \\
\hline Bias & Authors' judgement & Support for judgement \\
\hline $\begin{array}{l}\text { Random sequence generation (selection } \\
\text { bias) }\end{array}$ & Low risk & Used a random number list. \\
\hline Allocation concealment (selection bias) & Unclear risk & Insufficient information to permit judgment. \\
\hline $\begin{array}{l}\text { Blinding (performance bias and detection } \\
\text { bias) } \\
\text { Patients and providers }\end{array}$ & High risk & No blinding. \\
\hline $\begin{array}{l}\text { Blinding (performance bias and detection } \\
\text { bias) } \\
\text { Assessors }\end{array}$ & Low risk & $\begin{array}{l}\text { "Undergraduate assistants blind to the randomization collected } \\
\text { participant data at the follow-up." }\end{array}$ \\
\hline $\begin{array}{l}\text { Incomplete outcome data (attrition bias) } \\
\text { All outcomes }\end{array}$ & Low risk & $\begin{array}{l}7 \% \text { lost-to-follow-up at } 2 \text { months, balanced across groups. Rea- } \\
\text { sons stated. Not ITT. }\end{array}$ \\
\hline Selective reporting (reporting bias) & Low risk & $\begin{array}{l}\text { The published report included all expected outcomes based on } \\
\text { the study hypotheses. }\end{array}$ \\
\hline Other bias & Unclear risk & $\begin{array}{l}\text { Only self-reported outcomes. Differences between groups at } \\
\text { baseline were not reported. }\end{array}$ \\
\hline
\end{tabular}

\section{Freyer-Adam 2008}

\begin{tabular}{ll}
\hline Methods & Quasi-RCT. \\
\hline Participants & $\begin{array}{l}595 \text { general hospital patients. } 25 \% \text { were alcohol abusers, } 57 \% \text { at -risk drinkers, and } 18 \% \\
\text { heavy episodic drinkers. Germany. }\end{array}$ \\
\hline Interventions & $\begin{array}{l}\text { 1. MI by liaison service }(\mathrm{n}=249) \\
\text { 2. MI by hospital physicians }(\mathrm{n}=121) \\
\text { 3.TAU }(\mathrm{n}=225) .\end{array}$
\end{tabular}




\begin{tabular}{|c|c|c|}
\hline Outcomes & \multicolumn{2}{|c|}{$\begin{array}{l}\text { Physiological primary: None. } \\
\text { Non-physiological primary: Gram alcohol per day, gram alcohol past week. } \\
\text { Secondary: Readiness to change drinking. }\end{array}$} \\
\hline Notes & \multicolumn{2}{|c|}{ It was not possible to monitor the fidelity of the intervention in physician arm. } \\
\hline \multicolumn{3}{|l|}{ Risk of bias } \\
\hline Bias & Authors' judgement & Support for judgement \\
\hline $\begin{array}{l}\text { Random sequence generation (selection } \\
\text { bias) }\end{array}$ & High risk & $\begin{array}{l}\text { "...randomisation was conducted by time-frame, based on the } \\
\text { date of admission." }\end{array}$ \\
\hline Allocation concealment (selection bias) & Unclear risk & Insufficient information to permit judgement. \\
\hline $\begin{array}{l}\text { Blinding (performance bias and detection } \\
\text { bias) } \\
\text { Patients and providers }\end{array}$ & High risk & No blinding. \\
\hline $\begin{array}{l}\text { Blinding (performance bias and detection } \\
\text { bias) } \\
\text { Assessors }\end{array}$ & High risk & $\begin{array}{l}\text { "...the staff was not blind to the study group to which the par- } \\
\text { ticipants had been assigned." }\end{array}$ \\
\hline $\begin{array}{l}\text { Incomplete outcome data (attrition bias) } \\
\text { All outcomes }\end{array}$ & High risk & $\begin{array}{l}29 \% \text { lost to follow-up at } 12 \text { months, not balanced, reasons pro- } \\
\text { vided. Not ITT. }\end{array}$ \\
\hline Selective reporting (reporting bias) & Low risk & $\begin{array}{l}\text { The published report included all expected outcomes based on } \\
\text { the study hypotheses. }\end{array}$ \\
\hline Other bias & High risk & $\begin{array}{l}\text { Only self-reported outcomes. Because staff became more experi- } \\
\text { enced over time, they might have recruited different patients in } \\
\text { the first period when they recruited the controls than in the later } \\
\text { period when they recruited to the intervention groups. There } \\
\text { were differences between groups at baseline on satisfaction with } \\
\text { health, age, and having an intimate partner. }\end{array}$ \\
\hline
\end{tabular}

Kadden 2007

\begin{tabular}{ll}
\hline Methods & RCT (dismantling design). \\
\hline Participants & 240 adult marijuana smokers meeting DSM-IV criteria for cannabis dependence. USA. \\
\hline Interventions & $\begin{array}{l}\text { 9 weeks of one of four conditions: } \\
\text { 1. case management control condition }(n=62) \\
\text { 2. MET/CBT coping skills training }(n=61) \\
\text { 3. contingency management }(n=54) \\
\text { 4. MET/CBT + Contingency management }(n=63) .\end{array}$
\end{tabular}


Kadden 2007 (Continued)

\begin{tabular}{ll} 
Outcomes & $\begin{array}{l}\text { Physiological primary: None. } \\
\text { Non-physiological primary: Total 90-day continuous abstinence. Proportion of days } \\
\text { abstinent. } \\
\text { Secondary: Readiness to change (Readiness to Change Questionnaire). } \\
\text { Follow-up was at } 2 \text { months posttreatment. }\end{array}$ \\
\hline Notes & \\
\hline
\end{tabular}

Risk of bias

\begin{tabular}{|c|c|c|}
\hline Bias & Authors' judgement & Support for judgement \\
\hline $\begin{array}{l}\text { Random sequence generation (selection } \\
\text { bias) }\end{array}$ & Low risk & Computerized urn randomisation. \\
\hline Allocation concealment (selection bias) & Unclear risk & Insufficient information to permit judgement. \\
\hline $\begin{array}{l}\text { Blinding (performance bias and detection } \\
\text { bias) } \\
\text { Patients and providers }\end{array}$ & Unclear risk & $\begin{array}{l}\text { No blinding but the outcome measurements are not likely } \\
\text { to be influenced by lack of blinding due to validation with } \\
\text { physiological measurement. }\end{array}$ \\
\hline $\begin{array}{l}\text { Blinding (performance bias and detection } \\
\text { bias) } \\
\text { Assessors }\end{array}$ & Unclear risk & $\begin{array}{l}\text { Insufficient information to tell if assessor was blinded, but } \\
\text { the outcome measurements are not likely to be influenced } \\
\text { by lack of blinding due to validation with physiological } \\
\text { measurement. }\end{array}$ \\
\hline $\begin{array}{l}\text { Incomplete outcome data (attrition bias) } \\
\text { All outcomes }\end{array}$ & Unclear risk & $\begin{array}{l}17 \% \text { lost to follow-up with reasons stated. Different attri- } \\
\text { tion across groups. No ITT. }\end{array}$ \\
\hline Selective reporting (reporting bias) & Low risk & $\begin{array}{l}\text { The published report included all expected outcomes } \\
\text { based on the study purposes. }\end{array}$ \\
\hline Other bias & Low risk & $\begin{array}{l}\text { Urine samples were collected to check on self-report. } \\
\text { There were no differences between groups at baseline. No } \\
\text { additional sources of bias appear to be present. }\end{array}$ \\
\hline
\end{tabular}

Kahler 2004

\begin{tabular}{ll}
\hline Methods & RCT. \\
\hline Participants & 48 US patients undergoing inpatient detoxification for alcohol dependence. \\
\hline Interventions & MET for 12-step involvement $(\mathrm{n}=24)$ vs brief advice to attend AA $(\mathrm{n}=24)$. \\
\hline Outcomes & $\begin{array}{l}\text { Physiological primary: None. } \\
\text { Non-physiological primary: Percent of days abstinent, drinks per drinking day. } \\
\text { Secondary: AA/NA attendance and involvement. }\end{array}$
\end{tabular}




\section{Risk of bias}

\begin{tabular}{|c|c|c|}
\hline Bias & Authors' judgement & Support for judgement \\
\hline $\begin{array}{l}\text { Random sequence generation (selection } \\
\text { bias) }\end{array}$ & Unclear risk & $\begin{array}{l}\text { "Eight cohorts of } 6 \text { participants were run to obtain the desired } \\
\text { sample with treatment conditions for each cohort determined } \\
\text { randomly." }\end{array}$ \\
\hline Allocation concealment (selection bias) & Unclear risk & Insufficient information to permit judgment. \\
\hline $\begin{array}{l}\text { Blinding (performance bias and detection } \\
\text { bias) } \\
\text { Patients and providers }\end{array}$ & High risk & No blinding. \\
\hline $\begin{array}{l}\text { Blinding (performance bias and detection } \\
\text { bias) } \\
\text { Assessors }\end{array}$ & Low risk & $\begin{array}{l}\text { "RAs (research assistants) were blind to treatment assignment of } \\
\text { individuals and cohorts." }\end{array}$ \\
\hline $\begin{array}{l}\text { Incomplete outcome data (attrition bias) } \\
\text { All outcomes }\end{array}$ & Low risk & $\begin{array}{l}48 \text { were randomised. Attrition was } 4 \%, 4 \%, 6 \%, 6 \%, 12 \% \text {, } \\
\text { and } 12 \% \text { at } 1,2,3,4,5 \text {, and } 6 \text { months follow-up, respectively. No } \\
\text { reasons for insufficient data reported. No ITT performed. }\end{array}$ \\
\hline Selective reporting (reporting bias) & Low risk & $\begin{array}{l}\text { The published report included all expected outcomes based on } \\
\text { the study hypotheses. }\end{array}$ \\
\hline Other bias & Unclear risk & $\begin{array}{l}\text { Collateral reports were used. However, because the two treat- } \\
\text { ments were of different length, it is not possible to deter- } \\
\text { mine whether treatment intensity rather than treatment content } \\
\text { caused the observed effects. There were no differences between } \\
\text { groups at baseline. }\end{array}$ \\
\hline
\end{tabular}

\section{Kavanagh 2004}

\begin{tabular}{ll}
\hline Methods & RCT. \\
\hline Participants & 25 Australian inpatients with current misuse of non-opioid drugs. \\
\hline Interventions & Start Over and Survive $(\mathrm{n}=13)$ vs standard care $(\mathrm{n}=12)$. \\
\hline Outcomes & $\begin{array}{l}\text { Physiological primary: None. } \\
\text { Non-physiological primary: Abstinent or improved on all substances. } \\
\text { Secondary: None. }\end{array}$ \\
\hline
\end{tabular}

Notes 
Kavanagh 2004 (Continued)

\section{Risk of bias}

\begin{tabular}{|c|c|c|}
\hline Bias & Authors' judgement & Support for judgement \\
\hline $\begin{array}{l}\text { Random sequence generation (selection } \\
\text { bias) }\end{array}$ & Low risk & $\begin{array}{l}\text { "...participants were allocated randomly to conditions using a } \\
\text { separate table of random permutations for each site." }\end{array}$ \\
\hline Allocation concealment (selection bias) & Unclear risk & Insufficient information to permit judgment. \\
\hline $\begin{array}{l}\text { Blinding (performance bias and detection } \\
\text { bias) } \\
\text { Patients and providers }\end{array}$ & High risk & No blinding. \\
\hline $\begin{array}{l}\text { Blinding (performance bias and detection } \\
\text { bias) } \\
\text { Assessors }\end{array}$ & Low risk & $\begin{array}{l}\text { "The final assessment was undertaken by research staff who were } \\
\text { blind to treatment conditions." }\end{array}$ \\
\hline $\begin{array}{l}\text { Incomplete outcome data (attrition bias) } \\
\text { All outcomes }\end{array}$ & Unclear risk & $\begin{array}{l}\text { Attrition was } 4 \% \text { at } 6 \text { months and } 32 \% \text { at } 12 \text { months. Balanced. } \\
\text { We do not know the attrition at } 6 \text { weeks and } 3 \text { months. Reasons } \\
\text { for loss were not reported. ITT was performed. }\end{array}$ \\
\hline Selective reporting (reporting bias) & High risk & $\begin{array}{l}\text { Not separate results for AUDIT, Severity of Dependence Scale } \\
\text { and the Drug Check. Results for number abstinent and number } \\
\text { improved were collapsed. }\end{array}$ \\
\hline Other bias & High risk & $\begin{array}{l}\text { Only self-reported outcomes. Groups were significantly different } \\
\text { at baseline. Because there was no contact control it is possible } \\
\text { that the positive results were due to contact alone. Participants in } \\
\text { the Start Over and Survive group had longer length of stay and } \\
\text { less confidence in controlling substance abuse, and were living } \\
\text { with fewer family members than participants in the standard } \\
\text { care group at baseline. }\end{array}$ \\
\hline
\end{tabular}

Kay-Lambkin 2009

\begin{tabular}{ll}
\hline Methods & RCT \\
\hline Participants & 97 Australian people with comorbid major depression and alcohol/cannabis misuse. \\
\hline Interventions & $\begin{array}{l}\text { Brief intervention for depressive symptoms followed by randomisation into } 3 \text { different } \\
\text { groups: } \\
\text { 1. therapist-delivered MI/CBT }(\mathrm{n}=35) \\
\text { 2. computer-delivered MI/CBT }(\mathrm{n}=32) \\
\text { 3. no further treatment }(\mathrm{n}=30)\end{array}$ \\
\hline
\end{tabular}


Kay-Lambkin 2009 (Continued)

(OTI) and the SCID-RV.

\begin{tabular}{ll} 
Notes & $\begin{array}{l}\text { In one condition, MI/CBT was delivered by computer (not considered in this review) } \\
\text {. Intervention is called SHADE therapy (Self-Help for Alcohol and other drug use and } \\
\text { Depression). }\end{array}$ \\
\hline
\end{tabular}

Risk of bias

\begin{tabular}{|c|c|c|}
\hline Bias & Authors' judgement & Support for judgement \\
\hline $\begin{array}{l}\text { Random sequence generation (selection } \\
\text { bias) }\end{array}$ & Low risk & $\begin{array}{l}\text { "A permuted block randomisation approach was used so that the } \\
\text { distribution of participants across treatment conditions could } \\
\text { be maintained regardless of the final sample size." }\end{array}$ \\
\hline Allocation concealment (selection bias) & Low risk & $\begin{array}{l}\text { "Treatment allocations were transferred from this list by an ad- } \\
\text { ministrative assistant and concealed in individual envelopes la- } \\
\text { belled with the relevant participant code. Neither of these pro- } \\
\text { cesses was conducted by personnel involved with the assessment } \\
\text { or treatment phases of the study. Prior to the BI session, the re- } \\
\text { search clinicians were issued with a new randomisation envelope } \\
\text { by the administrative assistant, which displayed the participant } \\
\text { number on the outside of the envelope with the treatment allo- } \\
\text { cation sealed inside. The envelope was opened by the participant } \\
\text { at the conclusion } \\
\text { of the BI session." }\end{array}$ \\
\hline
\end{tabular}

Blinding (performance bias and detection High risk

Patients and providers were not blinded.

bias)

Patients and providers

Blinding (performance bias and detection Low risk bias)

Assessors

"At the conclusion of the treatment period all participants, regardless of treatment completion, met with an independent research clinician, blind to treatment allocation,

to complete follow-up assessments."

Incomplete outcome data (attrition bias) Low risk All outcomes

Selective reporting (reporting bias)

Low risk

Other bias $\quad$ Unclear risk
Attrition was $16 \%$ at 3 months follow-up, $19 \%$ at 6 months, and $16 \%$ at 12 months. Reasons provided. Not stated whether attrition was balanced. ITT was performed.

The published report included all expected outcomes based on the study hypotheses.
Only self-reported outcomes. Differences between groups at baseline were not fully reported. Age and gender were similar. No additional sources of bias appear to be present. 
Kelly 2000

\begin{tabular}{|c|c|c|}
\hline Methods & \multicolumn{2}{|l|}{ RCT. } \\
\hline Participants & \multicolumn{2}{|c|}{32 Australian women with alcohol and marital problems. } \\
\hline Interventions & \multicolumn{2}{|c|}{$\begin{array}{l}\text { Alcohol focused treatment (including MI, CBT strategies and relapse prevention) }(\mathrm{n}= \\
\text { 16) vs } 1 \text { month waiting list control group }(\mathrm{n}=16) \text {. }\end{array}$} \\
\hline Outcomes & \multicolumn{2}{|c|}{$\begin{array}{l}\text { Physiological primary: None. } \\
\text { Non-physiological primary: Standard drinks per drinking day. } \\
\text { Secondary: None. }\end{array}$} \\
\hline \multicolumn{3}{|l|}{ Notes } \\
\hline \multicolumn{3}{|l|}{ Risk of bias } \\
\hline Bias & Authors' judgement & Support for judgement \\
\hline $\begin{array}{l}\text { Random sequence generation (selection } \\
\text { bias) }\end{array}$ & Unclear risk & “...assigned randomly." \\
\hline Allocation concealment (selection bias) & Unclear risk & Insufficient information to permit judgment. \\
\hline $\begin{array}{l}\text { Blinding (performance bias and detection } \\
\text { bias) } \\
\text { Patients and providers }\end{array}$ & High risk & No blinding. \\
\hline $\begin{array}{l}\text { Blinding (performance bias and detection } \\
\text { bias) } \\
\text { Assessors }\end{array}$ & Unclear risk & It is not stated whether the assessors were blinded. \\
\hline $\begin{array}{l}\text { Incomplete outcome data (attrition bias) } \\
\text { All outcomes }\end{array}$ & High risk & $\begin{array}{l}28 \% \text { attrition at } 1 \text { month, } 31 \% \text { attrition at } 6 \text { months, and } 38 \% \\
\text { attrition at the } 12 \text { months follow-up. Balanced across groups. } \\
\text { Not clear whether ITT was performed. Reasons for loss not } \\
\text { reported. }\end{array}$ \\
\hline Selective reporting (reporting bias) & Low risk & $\begin{array}{l}\text { The published report included all expected outcomes based on } \\
\text { the study hypotheses. }\end{array}$ \\
\hline Other bias & Low risk & $\begin{array}{l}\text { Collateral report to check on self-report. There were no differ- } \\
\text { ences between groups at baseline. No additional sources of bias } \\
\text { appear to be present. }\end{array}$ \\
\hline
\end{tabular}


Maisto 2001

\begin{tabular}{ll}
\hline Methods & Multisite RCT (12 sites). \\
\hline Participants & $\begin{array}{l}301 \text { hazardous alcohol using elderly US patients who presented for treatment at a primary } \\
\text { care clinic. }\end{array}$ \\
\hline Interventions & $\begin{array}{l}\text { 1. MET ( } \mathrm{n}=101) \\
\text { 2. brief advice }(\mathrm{n}=100) \\
\text { 3. standard care }(\mathrm{n}=100) .\end{array}$ \\
\hline Outcomes & $\begin{array}{l}\text { Physiological primary: None. } \\
\text { Non-physiological primary: Days abstinent, number of drinks, drinks per drinking } \\
\text { day, days } 1-6 \text { drinks. } \\
\text { Secondary: Readiness to change (Stages of Change Readiness and Treatment Eagerness } \\
\text { Scale [SOCRATES]). Data not reported. } \\
\text { Follow-up at 1,3,6,9, and 12 months. }\end{array}$ \\
\hline Notes & We do not have follow-up data on 1, 3, and 9 months. \\
\hline
\end{tabular}

\section{Risk of bias}

\begin{tabular}{lll}
\hline Bias & Authors' judgement & Support for judgement \\
\hline $\begin{array}{l}\text { Random sequence generation (selection } \\
\text { bias) }\end{array}$ & Low risk & Random numbers table. \\
\hline $\begin{array}{l}\text { Allocation concealment (selection bias) } \\
\text { Low risk }\end{array}$ & $\begin{array}{l}\text { "The schedule was kept in an envelope in a locked drawer } \\
\text { and was used only by the project coordinator." }\end{array}$ \\
\hline $\begin{array}{l}\text { Blinding (performance bias and detection } \\
\text { bias) } \\
\text { Patients and providers }\end{array}$ & High risk & No blinding. \\
\hline
\end{tabular}

Blinding (performance bias and detection Unclear risk

It is not stated whether the assessors were blinded.

bias)

Assessors

\begin{tabular}{|c|c|c|}
\hline $\begin{array}{l}\text { Incomplete outcome data (attrition bias) } \\
\text { All outcomes }\end{array}$ & High risk & $\begin{array}{l}\text { Attrition was } 5 \%, 8 \%, 14 \%, 15 \% \text {, and } 17 \% \text { at } 1 \text { month, } 3 \\
\text { months, } 6 \text { months, } 9 \text { months, and } 12 \text { months, respectively. } \\
\text { Reasons for loss not reported. We don't know if loss was } \\
\text { balanced across groups. No ITT reported. }\end{array}$ \\
\hline Selective reporting (reporting bias) & Low risk & $\begin{array}{l}\text { The published report included all expected outcomes based } \\
\text { on the study hypotheses. }\end{array}$ \\
\hline Other bias & Low risk & $\begin{array}{l}\text { Collateral reports were used to check on self-report. There } \\
\text { were no differences between groups at baseline. No addi- } \\
\text { tional sources of bias appear to be present. }\end{array}$ \\
\hline
\end{tabular}


MarijuanaTP 2004

\begin{tabular}{ll}
\hline Methods & Multisite RCT (3 sites). \\
\hline Participants & 450 US cannabis dependent adults. \\
\hline Interventions & $\begin{array}{l}1.2 \text { session MET ( } \mathrm{n}=146) \\
2.9 \text { session MET }(\mathrm{n}=156) \\
34 \text { month delayed treatment ( } \mathrm{n}=148) .\end{array}$ \\
\hline Outcomes & $\begin{array}{l}\text { Physiological primary: None. } \\
\text { Non-physiological primary: Percent of days smoking, periods smoked per day, joints } \\
\text { per day, dependence symptoms, abuse symptoms, marijuana problems. } \\
\text { Secondary: None. }\end{array}$ \\
\hline Notes & \\
\hline
\end{tabular}

\section{Risk of bias}

\begin{tabular}{|c|c|c|}
\hline Bias & Authors' judgement & Support for judgement \\
\hline $\begin{array}{l}\text { Random sequence generation (selection } \\
\text { bias) }\end{array}$ & Low risk & Urn randomisation. \\
\hline Allocation concealment (selection bias) & Unclear risk & Insufficient information to permit judgment. \\
\hline $\begin{array}{l}\text { Blinding (performance bias and detection } \\
\text { bias) } \\
\text { Patients and providers }\end{array}$ & Unclear risk & $\begin{array}{l}\text { No blinding but the outcome measurements are not likely } \\
\text { to be influenced by lack of blinding due to validation with } \\
\text { physiological measurement. }\end{array}$ \\
\hline $\begin{array}{l}\text { Blinding (performance bias and detection } \\
\text { bias) } \\
\text { Assessors }\end{array}$ & Unclear risk & $\begin{array}{l}\text { "Research assistants were not blinded to the participants' ex- } \\
\text { perimental conditions." But the outcome measurements are } \\
\text { not likely to be influenced by lack of blinding due to valida- } \\
\text { tion with physiological measurement. }\end{array}$ \\
\hline $\begin{array}{l}\text { Incomplete outcome data (attrition bias) } \\
\text { All outcomes }\end{array}$ & Low risk & $\begin{array}{l}\text { Loss to follow-up at } 4 \text { months, } 9 \text { months and } 15 \text { months were } \\
11 \%, 13 \% \text { and } 17 \% \text {, respectively. Balanced. No reasons for } \\
\text { loss reported. ITT performed (analysis of missing cases using } \\
\text { baseline values.) }\end{array}$ \\
\hline Selective reporting (reporting bias) & Low risk & $\begin{array}{l}\text { The published report included all expected outcomes based } \\
\text { on the study hypotheses. }\end{array}$ \\
\hline Other bias & Unclear risk & $\begin{array}{l}\text { Collateral interviews and urine specimens to check on self-re- } \\
\text { port. Numbers of sessions were confounded with differential } \\
\text { content and process. Different expectancies of success were } \\
\text { created by the differences in treatment length. There were no } \\
\text { differences between groups at baseline. }\end{array}$ \\
\hline
\end{tabular}


Marsden 2006

\begin{tabular}{ll}
\hline Methods & Multisite RCT (5 sites). \\
\hline Participants & 342 UK adolescent and young adult stimulant users. \\
\hline Interventions & BMI ( $\mathrm{n}=166)$ vs written health risk information $(\mathrm{n}=176)$. \\
\hline Outcomes & $\begin{array}{l}\text { Physiological primary: None. } \\
\text { Non-physiological primary: Ecstasy number of days, ecstasy tablets, cocaine powder } \\
\text { number of days, cocaine g/day, crack number of days, crack g/day, cannabis number of } \\
\text { days, cannabis g/day, alcohol number of days, alcohol g/weekday, alcohol g/weekend. } \\
\text { Secondary: None. }\end{array}$ \\
\hline Notes & \\
\hline
\end{tabular}

\section{Risk of bias}

\begin{tabular}{|c|c|c|}
\hline Bias & Authors' judgement & Support for judgement \\
\hline $\begin{array}{l}\text { Random sequence generation (selection } \\
\text { bias) }\end{array}$ & Unclear risk & "two-group randomised controlled trial". \\
\hline Allocation concealment (selection bias) & Unclear risk & Insufficient information to permit judgment. \\
\hline $\begin{array}{l}\text { Blinding (performance bias and detection } \\
\text { bias) } \\
\text { Patients and providers }\end{array}$ & Unclear risk & $\begin{array}{l}\text { No blinding but the outcome measurements are not likely } \\
\text { to be influenced by lack of blinding due to validation with } \\
\text { physiological measurement. }\end{array}$ \\
\hline $\begin{array}{l}\text { Blinding (performance bias and detection } \\
\text { bias) } \\
\text { Assessors }\end{array}$ & Low risk & $\begin{array}{l}\text { "To guard against bias, all follow-up interviews were con- } \\
\text { ducted by a different worker from the one who administered } \\
\text { the participant's recruitment protocol." }\end{array}$ \\
\hline $\begin{array}{l}\text { Incomplete outcome data (attrition bias) } \\
\text { All outcomes }\end{array}$ & Low risk & $\begin{array}{l}13 \% \text { attrition at } 6 \text { months follow-up, balanced across condi- } \\
\text { tions. Reasons not provided. "The analysis of outcome was } \\
\text { conducted on an intention-to-treat (ITT) basis (involving all } \\
\text { participants who were randomly assigned) and baseline scores } \\
\text { were substituted for cases lost to follow-up." }\end{array}$ \\
\hline Selective reporting (reporting bias) & Low risk & $\begin{array}{l}\text { The published report included all expected outcomes based } \\
\text { on the study hypotheses. }\end{array}$ \\
\hline Other bias & Low risk & $\begin{array}{l}\text { Stimulant toxicology testing on a random } 30 \% \text {. There were } \\
\text { no differences between groups at baseline. No additional } \\
\text { sources of bias appear to be present. }\end{array}$ \\
\hline
\end{tabular}


Martin 2008

\begin{tabular}{ll}
\hline Methods & RCT. \\
\hline Participants & 40 non-treatment-seeking adolescent cannabis users from Australia aged 14-19 years. \\
\hline Interventions & $\begin{array}{l}\text { Two-session brief intervention }(\mathrm{n}=20) \text { vs a 3-month delayed-treatment control condition } \\
(\mathrm{n}=20) .\end{array}$ \\
\hline Outcomes & $\begin{array}{l}\text { Physiological primary: Urine test. } \\
\text { Non-physiological primary: Days of cannabis use, mean quantity of cannabis used } \\
\text { weekly, and number of DSM-IV dependence symptoms. } \\
\text { Secondary: None. }\end{array}$ \\
\hline Notes & Intervention is referred to as ACCU (Adolescent Cannabis Check-up). \\
\hline
\end{tabular}

\section{Risk of bias}

\begin{tabular}{lll} 
Bias & Authors' judgement & Support for judgement \\
\hline $\begin{array}{l}\text { Random sequence generation (selection } \\
\text { bias) }\end{array}$ & Low risk & $\begin{array}{l}\text { "The randomisation sequence was generated by a computer ran- } \\
\text { dom number generator." }\end{array}$ \\
\hline Allocation concealment (selection bias) & Low risk & $\begin{array}{l}\text { “...participants were randomly allocated to one of the two condi- } \\
\text { tions by means of a sequence of labelled cards contained within } \\
\text { numbered sealed (opaque) envelopes that were prepared by an } \\
\text { independent researcher and opened in the presence of the par- } \\
\text { ticipant." }\end{array}$ \\
\hline
\end{tabular}

Blinding (performance bias and detection Low risk No blinding, but most outcomes were physiological and also bias) used to validate self-reports, and not likely to be influenced by Patients and providers lack of blinding.

Blinding (performance bias and detection Low risk bias)

Assessors
"Participants were followed up by an independent researcher 3 months after their last involvement with the project." Most outcomes were physiological and also used to validate self-reports, and not likely to be influenced by lack of blinding.
Incomplete outcome data (attrition bias) Low risk All outcomes
Low risk

Unclear risk
$20 \%$ were lost to follow-up. Equal attrition across groups. Intention to treat conducted. Reasons for attrition not reported.

The published report included all expected outcomes based on the study purposes.

Other bias
Urinanalysis to validate self-report. The treatment group reported significantly more days of cannabis use in the past 90 days than the control group. 
Martino 2006

\begin{tabular}{|c|c|}
\hline Methods & Pilot RCT. \\
\hline Participants & 44 dually diagnosed psychotic and drug-related disordered patients. USA. \\
\hline Interventions & Two sessions of MI ( $\mathrm{n}=24)$ vs a two-session standard psychiatric interview $(\mathrm{n}=20)$. \\
\hline Outcomes & $\begin{array}{l}\text { Physiological primary: None. } \\
\text { Non-physiological primary: Days of primary drug use, secondary drug use, alcohol } \\
\text { use. } \\
\text { Secondary: Retention in treatment. } \\
\text { Readiness to change (URICA). Data not reported. } \\
\text { Follow-ups were at posttreatment, 1, 2, and } 3 \text { months. }\end{array}$ \\
\hline Notes & \\
\hline
\end{tabular}

\section{Risk of bias}

\section{Bias}

\section{Authors' judgement Support for judgement}

Random sequence generation (selection Low risk Urn randomisation.

bias)

\begin{tabular}{|c|c|c|}
\hline Allocation concealment (selection bias) & Unclear risk & Insufficient information to permit judgement. \\
\hline $\begin{array}{l}\text { Blinding (performance bias and detection } \\
\text { bias) } \\
\text { Patients and providers }\end{array}$ & Low risk & $\begin{array}{l}\text { Blinding of providers was not possible, but participants could } \\
\text { have been blinded. }\end{array}$ \\
\hline $\begin{array}{l}\text { Blinding (performance bias and detection } \\
\text { bias) } \\
\text { Assessors }\end{array}$ & Low risk & $\begin{array}{l}\text { "...two research staff members administered the assessments in } \\
\text { a non-blinded fashion." }\end{array}$ \\
\hline $\begin{array}{l}\text { Incomplete outcome data (attrition bias) } \\
\text { All outcomes }\end{array}$ & Low risk & $\begin{array}{l}14 \% \text { were lost to at least one follow up, balanced across groups. } \\
\text { Reasons for loss not stated. ITT performed. }\end{array}$ \\
\hline Selective reporting (reporting bias) & Low risk & $\begin{array}{l}\text { The published report included all expected outcomes based on } \\
\text { the study purposes. }\end{array}$ \\
\hline Other bias & High risk & $\begin{array}{l}\text { Only self-reported outcomes. There were differences at baseline } \\
\text { in alcohol composite score and legal involvement. }\end{array}$ \\
\hline
\end{tabular}

\section{Mastroleo 2010}

\begin{tabular}{ll}
\hline Methods & RCT. \\
\hline Participants & 122 US heavy drinking college students.
\end{tabular}


Mastroleo 2010 (Continued)

\begin{tabular}{|c|c|c|}
\hline Interventions & \multicolumn{2}{|c|}{$\begin{array}{l}\text { 1. peer counselled MI with supervision }(n=74) \\
\text { 2. peer counselled MI without supervision }(n=82) \\
\text { 3. no treatment control }(n=82) \text {. }\end{array}$} \\
\hline Outcomes & \multicolumn{2}{|c|}{$\begin{array}{l}\text { Daily Drinking Questionnaire (total drinks per week, peak BAC, heavy drinking be- } \\
\text { haviours). }\end{array}$} \\
\hline \multicolumn{3}{|l|}{ Notes } \\
\hline \multicolumn{3}{|l|}{ Risk of bias } \\
\hline Bias & Authors' judgement & Support for judgement \\
\hline $\begin{array}{l}\text { Random sequence generation (selection } \\
\text { bias) }\end{array}$ & Unclear risk & No mention of allocation method. \\
\hline Allocation concealment (selection bias) & Unclear risk & No mention of allocation concealment. \\
\hline $\begin{array}{l}\text { Blinding (performance bias and detection } \\
\text { bias) } \\
\text { Patients and providers }\end{array}$ & High risk & Patient and providers were not blinded to treatment allocation. \\
\hline $\begin{array}{l}\text { Blinding (performance bias and detection } \\
\text { bias) } \\
\text { Assessors }\end{array}$ & Unclear risk & It is not stated whether assessors were blinded. \\
\hline $\begin{array}{l}\text { Incomplete outcome data (attrition bias) } \\
\text { All outcomes }\end{array}$ & Low risk & $\begin{array}{l}16 \% \text { attrition at } 3 \text { months. Balanced. No reasons stated. ITT } \\
\text { (imputed missing data). }\end{array}$ \\
\hline Selective reporting (reporting bias) & Low risk & $\begin{array}{l}\text { The published report included all expected outcomes based on } \\
\text { the study purposes. }\end{array}$ \\
\hline Other bias & Unclear risk & $\begin{array}{l}\text { Only self-reported outcomes. } 61 / 156 \text { (39\%) of randomised par- } \\
\text { ticipants did not receive the intervention. Differences between } \\
\text { groups at baseline were not reported. }\end{array}$ \\
\hline
\end{tabular}

\section{MATCH 1993}

\begin{tabular}{ll}
\hline Methods & Multisite RCT ( 9 clinical research units and a coordinating centre). \\
\hline Participants & 1726 US inpatients and outpatients. \\
\hline Interventions & $\begin{array}{l}\text { Motivational Enhancement Therapy (MET) vs Cognitive Behavioral Therapy (CBT) } \\
\text { vs Twelve-Step Facilitation Therapy (TSF). Not reported how many people were ran- } \\
\text { domised to each condition. }\end{array}$
\end{tabular}


MATCH 1993 (Continued)

\begin{tabular}{l|l} 
Outcomes & $\begin{array}{l}\text { Physiological primary: Gamma-glutamyl transferase. } \\
\text { Non-physiological primary: Percent days abstinent, drinks per drinking day, drinking } \\
\text { consequences, } \\
\text { Secondary: None. }\end{array}$ \\
\hline Notes & \\
\hline
\end{tabular}

\section{Risk of bias}

\begin{tabular}{l|l|l}
\hline Bias & Authors' judgement & Support for judgement \\
\hline $\begin{array}{l}\text { Random sequence generation (selection } \\
\text { bias) }\end{array}$ & Low risk & $\begin{array}{l}\text { "Randomization to treatment was per- } \\
\text { formed using a computerized urn balanc- } \\
\text { ing program designed to minimize differ- } \\
\text { ences on critical demographic and match- } \\
\text { ing variables". }\end{array}$ \\
\hline Allocation concealment (selection bias) & Unclear risk & $\begin{array}{l}\text { Randomization process centrally con- } \\
\text { trolled by the coordination centre. }\end{array}$ \\
\hline
\end{tabular}

Blinding (performance bias and detection Low risk bias)

Patients and providers
No blinding, but most outcomes were physiological and also used to validate selfreports, and not likely to be influenced by lack of blinding.

Blinding (performance bias and detection Unclear risk bias)

Assessors

Incomplete outcome data (attrition bias) Low risk All outcomes

\begin{tabular}{l|l}
\hline Selective reporting (reporting bias) & Unclear risk
\end{tabular}

No blinding, but most outcomes were physiological and also used to validate selfreports, and not likely to be influenced by lack of blinding.

Attrition was less than $10 \%$ at the 3, 6, 9, 12 , and 15 months follow-ups in the aftercare and outpatient groups. Balanced. Reasons for 3-year attrition in the outpatient group given. The authors state that all randomised participants are included in the analyses, but in a results table they included only data for subjects who had non missing values at all three time points.

Primary outcomes measures (PDA and $\mathrm{DDD}$ ) reported incompletely (only by graphs). Outcome for drinking consequences only reported in tables for 9- and 15 months follow-up. 
MATCH 1993 (Continued)

\begin{tabular}{l|l}
\hline Other bias & Low risk \\
& $\begin{array}{l}\text { Collateral report, laboratory tests (blood } \\
\text { and urine) as check on self-report. Breath- } \\
\text { alyzer at each assessment point. Inclusion } \\
\text { criteria contained no planned involvement } \\
\text { for additional treatment during the study } \\
\text { period. There were no differences between } \\
\text { groups at baseline. No additional sources } \\
\text { of bias appear to be present. }\end{array}$ \\
\hline
\end{tabular}

McCambridge 2008

\begin{tabular}{ll}
\hline Methods & RCT. \\
\hline Participants & $\begin{array}{l}326 \text { young cannabis users aged 16-19 years not seeking help from eleven London Further } \\
\text { Education colleges. UK. }\end{array}$ \\
\hline Interventions & $\begin{array}{l}\text { Single session intervention of MI ( } \mathrm{n}=164) \text { vs drug information and advice giving (n= } \\
162) .\end{array}$ \\
\hline Outcomes & $\begin{array}{l}\text { Physiological primary: None (but bogus pipeline). } \\
\text { Non-physiological primary: 30-day frequency of cannabis use (joints past week), 30- } \\
\text { day alcohol consumption (units of alcohol past week + AUDIT score). } \\
\text { Secondary: None. } \\
\text { Follow-ups were at } 3 \text { and } 6 \text { months. }\end{array}$ \\
\hline Notes &
\end{tabular}

\section{Risk of bias}

\begin{tabular}{lll}
\hline Bias & Authors' judgement & Support for judgement \\
\hline $\begin{array}{l}\text { Random sequence generation (selection } \\
\text { bias) }\end{array}$ & Unclear risk & $\begin{array}{l}\text { "Computerised individual randomisation was undertaken by the } \\
\text { local clinical trials unit." }\end{array}$ \\
\hline Allocation concealment (selection bias) & Low risk & $\begin{array}{l}\text { "Decisions were communicated on an individual basis via tele- } \\
\text { phone or e-mail to researchers after recruitment and baseline } \\
\text { data collection to preserve allocation concealment." }\end{array}$
\end{tabular}

Blinding (performance bias and detection Unclear risk bias)

Patients and providers

Blinding (performance bias and detection Low risk bias)

Assessors

\section{No blinding but bogus pipeline.}

"Study participants self-completed questionnaires which were distributed by a researcher who was blind to study allocation." 
McCambridge 2008 (Continued)

\begin{tabular}{|c|c|c|}
\hline $\begin{array}{l}\text { Incomplete outcome data (attrition bias) } \\
\text { All outcomes }\end{array}$ & Low risk & $\begin{array}{l}17 \% \text { and } 19 \% \text { lost to follow-up at } 3 \text { and } 6 \text { months, respec- } \\
\text { tively. Unequal between groups. Reasons for loss-to-follow-up } \\
\text { not stated. Intention to treat using last observation carried for- } \\
\text { ward. }\end{array}$ \\
\hline Selective reporting (reporting bias) & Low risk & $\begin{array}{l}\text { The published report included all expected outcomes based on } \\
\text { the stated hypotheses. }\end{array}$ \\
\hline Other bias & Low risk & $\begin{array}{l}\text { A bogus pipeline approach was used in addition to self-report. } \\
\text { There were no differences between groups at baseline. No addi- } \\
\text { tional sources of bias appears to be present. }\end{array}$ \\
\hline
\end{tabular}

Miller 2003

\begin{tabular}{ll}
\hline Methods & Multisite RCT (2 sites). \\
\hline Participants & $\begin{array}{l}208 \text { US outpatients and inpatients entering public agencies for treatment of drug prob- } \\
\text { lems. }\end{array}$ \\
\hline Interventions & 1 session MI ( $\mathrm{n}=104)$ vs treatment as usual $(\mathrm{n}=104)$.
\end{tabular}

Outcomes Physiological primary: Urine toxicology.

Non-physiological primary: Percent days abstinent from illicit drugs and alcohol.

Secondary: Retention (frequency of therapy sessions attended).

\section{Notes}

Risk of bias

\begin{tabular}{llll}
\hline Bias & Authors' judgement & Support for judgement \\
\hline $\begin{array}{l}\text { Random sequence generation (selection } \\
\text { bias) }\end{array}$ & Low risk & Urn randomisation. \\
\hline $\begin{array}{l}\text { Allocation concealment (selection bias) } \\
\text { Blinding (performance bias and detection }\end{array}$ & Unclear risk & Unclear risk \\
$\begin{array}{l}\text { Patients and providers } \\
\text { Blinding (performance bias and detection } \\
\text { bias) } \\
\text { Assessors }\end{array}$ & Low risk & Nompleting baseline assessment. \\
\hline $\begin{array}{l}\text { Incomplete outcome data (attrition bias) } \\
\text { All outcomes }\end{array}$ & Unclear risk & \begin{tabular}{l} 
Nout urine toxicology. \\
\hline
\end{tabular} & $\begin{array}{l}\text { "Assessment for all participants was conducted by experienced } \\
\text { interviewing staff of CASAA's Program Evaluation Services } \\
\text { unit, who were unaware of treatment group assignment." }\end{array}$ \\
\hline
\end{tabular}


Miller 2003 (Continued)

\begin{tabular}{|c|c|c|}
\hline Selective reporting (reporting bias) & Unclear risk & $\begin{array}{l}\text { Addiction Severity Index was reported in the methods section, } \\
\text { but it was not reported in the results section. }\end{array}$ \\
\hline Other bias & Unclear risk & $\begin{array}{l}\text { Urine drug screens and collateral reports were used to check } \\
\text { on self-report. There is a possibility that the standard care } \\
\text { group had received MI. The MI group received one additional } \\
\text { session. There were no differences between groups at baseline. }\end{array}$ \\
\hline
\end{tabular}

\section{Morgenstern 2009}

\begin{tabular}{|c|c|c|}
\hline Methods & \multicolumn{2}{|l|}{ RCT. } \\
\hline Participants & \multicolumn{2}{|c|}{150 non-treatment-seeking men who have sex with men. USA. } \\
\hline Interventions & \multicolumn{2}{|c|}{4 sessions of MI $(n=70)$ vs a 4-session educational control condition $(n=80)$. } \\
\hline Outcomes & \multicolumn{2}{|c|}{$\begin{array}{l}\text { Physiological primary: None. } \\
\text { Non-physiological primary: Days of any club drug use (Timeline Followback). } \\
\text { Secondary: None. } \\
\text { Follow-ups were at 3, 6, 9, and } 12 \text { months. }\end{array}$} \\
\hline \multicolumn{3}{|l|}{ Notes } \\
\hline \multicolumn{3}{|l|}{ Risk of bias } \\
\hline Bias & Authors' judgement & Support for judgement \\
\hline $\begin{array}{l}\text { Random sequence generation (selection } \\
\text { bias) }\end{array}$ & Low risk & Used an urn randomisation procedure. \\
\hline Allocation concealment (selection bias) & Unclear risk & Insufficient information to permit judgement. \\
\hline $\begin{array}{l}\text { Blinding (performance bias and detection } \\
\text { bias) } \\
\text { Patients and providers }\end{array}$ & Unclear risk & $\begin{array}{l}\text { No blinding but the outcome measurements are not likely to be } \\
\text { influenced by lack of blinding due to validation with physiolog- } \\
\text { ical measurement. }\end{array}$ \\
\hline $\begin{array}{l}\text { Blinding (performance bias and detection } \\
\text { bias) } \\
\text { Assessors }\end{array}$ & Unclear risk & $\begin{array}{l}\text { Insufficient information to tell if assessor was blinded, but the } \\
\text { outcome measurements are not likely to be influenced by lack } \\
\text { of blinding due to validation with physiological measurement. }\end{array}$ \\
\hline $\begin{array}{l}\text { Incomplete outcome data (attrition bias) } \\
\text { All outcomes }\end{array}$ & High risk & $\begin{array}{l}23 \% \text { attrition at } 12 \text { months. Not different between conditions. } \\
\text { No reasons stated. No ITT. }\end{array}$ \\
\hline Selective reporting (reporting bias) & Low risk & $\begin{array}{l}\text { The published report included all expected outcomes based on } \\
\text { the stated hypotheses. }\end{array}$ \\
\hline
\end{tabular}




\begin{tabular}{|c|c|c|}
\hline Other bias & Unclear risk & $\begin{array}{l}\text { Self-report was confirmed by urine toxicology testing. There was } \\
\text { more marijuana use in the treatment group at baseline. }\end{array}$ \\
\hline
\end{tabular}

Naar-King 2007

\begin{tabular}{ll}
\hline Methods & RCT. \\
\hline Participants & 65 youth (ages 16-25 years) living with HIV. USA. \\
\hline Interventions & MET(n= 32) vs wait list (n= 33). \\
\hline Outcomes & $\begin{array}{l}\text { Physiological primary: None. } \\
\text { Non-physiological primary: Number of standard drinks in one week and number of } \\
\text { times used marijuana in one week (via Timeline Follow-Back). } \\
\text { Secondary: None. } \\
\text { Follow-ups were at baseline, 3, and 6 months. }\end{array}$ \\
\hline Notes & The intervention is known as "Healthy Choices". \\
\hline
\end{tabular}

\section{Risk of bias}

\begin{tabular}{|c|c|c|}
\hline Bias & Authors' judgement & Support for judgement \\
\hline $\begin{array}{l}\text { Random sequence generation (selection } \\
\text { bias) }\end{array}$ & Low risk & $\begin{array}{l}\text { "Random numbers were generated by the project manager using } \\
\text { an Internet based random number generator and were placed in } \\
\text { sealed envelopes." }\end{array}$ \\
\hline Allocation concealment (selection bias) & Low risk & $\begin{array}{l}\text { "The data collector received sealed envelopes revealing randomi- } \\
\text { sation status, which were opened after the baseline assessment so } \\
\text { that the intervention sessions could be scheduled immediately } \\
\text { for the treatment group." }\end{array}$ \\
\hline $\begin{array}{l}\text { Blinding (performance bias and detection } \\
\text { bias) } \\
\text { Patients and providers }\end{array}$ & High risk & No blinding. \\
\hline $\begin{array}{l}\text { Blinding (performance bias and detection } \\
\text { bias) } \\
\text { Assessors }\end{array}$ & Unclear risk & It is not stated whether assessors were blinded. \\
\hline $\begin{array}{l}\text { Incomplete outcome data (attrition bias) } \\
\text { All outcomes }\end{array}$ & Low risk & $\begin{array}{l}\text { Attrition at } 6 \text { months was } 23 \% \text { for the whole sample. No reasons } \\
\text { stated. Balanced. ITT conducted. }\end{array}$ \\
\hline Selective reporting (reporting bias) & Low risk & $\begin{array}{l}\text { The published report included all expected outcomes based on } \\
\text { the stated hypotheses. }\end{array}$ \\
\hline
\end{tabular}


Naar-King 2007 (Continued)

\begin{tabular}{|c|c|c|}
\hline Other bias & Unclear risk & $\begin{array}{l}\text { Only self-reported outcomes. Differences between groups at } \\
\text { baseline were not reported. }\end{array}$ \\
\hline
\end{tabular}

\section{Parsons 2009}

\begin{tabular}{|c|c|c|}
\hline Methods & \multicolumn{2}{|l|}{ RCT. } \\
\hline Participants & \multicolumn{2}{|c|}{$\begin{array}{l}143 \text { HIV-positive men and women who were on antiretroviral medication and met } \\
\text { criteria for hazardous drinking. USA. }\end{array}$} \\
\hline Interventions & \multicolumn{2}{|c|}{$\begin{array}{l}\text { MI + cognitive-behavioral skills building }(n=65) \text { vs a time- and content-equivalent } \\
\text { educational condition }(n=78) \text {. }\end{array}$} \\
\hline Outcomes & \multicolumn{2}{|c|}{$\begin{array}{l}\text { Physiological primary: None. } \\
\text { Non-physiological primary: Standard drinks in the past and drinks per drinking day. } \\
\text { Secondary: Medication adherence. } \\
\text { Follow-up at baseline and at 3- and 6-month follow-ups. }\end{array}$} \\
\hline Notes & \multicolumn{2}{|c|}{$\begin{array}{l}\text { Intervention is known as Project PLUS (Positive Living Through Understanding and } \\
\text { Support). }\end{array}$} \\
\hline \multicolumn{3}{|l|}{ Risk of bias } \\
\hline Bias & Authors' judgement & Support for judgement \\
\hline $\begin{array}{l}\text { Random sequence generation (selection } \\
\text { bias) }\end{array}$ & Low risk & Urn randomisation procedures were used. \\
\hline Allocation concealment (selection bias) & Unclear risk & Insufficient information to permit judgement. \\
\hline $\begin{array}{l}\text { Blinding (performance bias and detection } \\
\text { bias) } \\
\text { Patients and providers }\end{array}$ & Unclear risk & $\begin{array}{l}\text { Blinding of providers was not possible, but participants could } \\
\text { have been blinded. }\end{array}$ \\
\hline $\begin{array}{l}\text { Blinding (performance bias and detection } \\
\text { bias) } \\
\text { Assessors }\end{array}$ & Unclear risk & It is not stated whether assessors were blinded. \\
\hline $\begin{array}{l}\text { Incomplete outcome data (attrition bias) } \\
\text { All outcomes }\end{array}$ & Low risk & $\begin{array}{l}\text { "An intent-to-treat analysis was used in which participants who } \\
\text { completed the first follow-up assessments were analyzed accord- } \\
\text { ing to their original assigned study condition irrespective of the } \\
\text { number of sessions attended." Attrition was } 9 \% \text { at the } 3 \text {-month } \\
\text { follow-up and } 10 \% \text { at the } 6 \text {-month follow-up with no signif- } \\
\text { cant difference in attrition between the } 2 \text { conditions. Reasons } \\
\text { for attrition provided. }\end{array}$ \\
\hline
\end{tabular}


Parsons 2009 (Continued)

\begin{tabular}{|c|c|c|}
\hline Selective reporting (reporting bias) & Low risk & $\begin{array}{l}\text { The published report included all expected outcomes based on } \\
\text { the stated hypotheses. }\end{array}$ \\
\hline Other bias & Unclear risk & $\begin{array}{l}\text { Only self-reported outcomes. Differences between groups at } \\
\text { baseline were not reported. }\end{array}$ \\
\hline
\end{tabular}

Peterson 2006

\begin{tabular}{ll}
\hline Methods & RCT. \\
\hline Participants & 285 US homeless adolescents recruited from drop-in centres and from street intercept. \\
\hline Interventions & $\begin{array}{l}\text { 1. Brief ME ( } \mathrm{n}=92) \\
\text { 2. assessment at follow-up ( } \mathrm{n}=94) \\
\text { 3. assessment only ( } \mathrm{n}=99) .\end{array}$ \\
\hline Outcomes & $\begin{array}{l}\text { Physiological primary: None. } \\
\text { Non-physiological primary: Marijuana drug use days, other illicit drug use days. } \\
\text { Secondary: None. }\end{array}$ \\
\hline Notes & \\
\hline
\end{tabular}

Risk of bias

Bias

Authors' judgement Support for judgement

Random sequence generation (selection Low risk “...a two-step urn randomizations on gender and ethnicity.” bias)

\begin{tabular}{lll}
\hline Allocation concealment (selection bias) & Unclear risk $\quad$ Randomization at central location. \\
\hline
\end{tabular}

Blinding (performance bias and detection Unclear risk bias)

Patients and providers

Blinding (performance bias and detection Unclear risk bias)

Assessors

Incomplete outcome data (attrition bias) Unclear risk All outcomes

Selective reporting (reporting bias)
No blinding but the outcome measurements are not likely to be influenced by lack of blinding due to validation with physiological measurement.

"Follow-up interviewers... were not blind to condition." The outcome measurements are not likely to be influenced by lack of blinding due to validation with physiological measurement.

$18 \%$ and $20 \%$ attrition at 1 and 3 month follow-up, respectively. Balanced. Reasons for loss to-follow-up not stated. Use of ITT was stated by the authors but not reported.

The published report included all expected outcomes based on the study hypotheses. 


\begin{tabular}{|c|c|c|}
\hline Other bias & Low risk & $\begin{array}{l}\text { Urine samples collected at } 3 \text { month follow-up. There were no } \\
\text { differences between groups at baseline. No additional sources of } \\
\text { bias appear to be present. }\end{array}$ \\
\hline
\end{tabular}

\section{Rohsenow 2004}

\begin{tabular}{|c|c|c|}
\hline Methods & \multicolumn{2}{|l|}{ RCT. } \\
\hline Participants & \multicolumn{2}{|c|}{165 US cocaine dependent patients. } \\
\hline Interventions & \multicolumn{2}{|c|}{$\begin{array}{l}\text { 1. MET followed by group coping skills }(n=44) \\
\text { 2. MET followed by drug education }(n=39) \\
\text { 3. meditation relaxation followed by group coping skills }(n=44) \\
\text { 4. mediation relaxation followed by drug education }(n=38) \text {. }\end{array}$} \\
\hline Outcomes & \multicolumn{2}{|c|}{$\begin{array}{l}\text { Physiological primary: None. } \\
\text { Non-physiological primary: Number of cocaine use days, percentage of days alcohol } \\
\text { used. } \\
\text { Secondary: Readiness to change (Cocaine Change Assessment Questionnaire). Data not } \\
\text { reported. } \\
\text { Retention in treatment (days treated in partial hospital [data not reported]). }\end{array}$} \\
\hline Notes & \multicolumn{2}{|c|}{ Results data are not available. Mail from Dr. Rohsenow May 19th 2010.} \\
\hline \multicolumn{3}{|l|}{ Risk of bias } \\
\hline Bias & Authors' judgement & Support for judgement \\
\hline $\begin{array}{l}\text { Random sequence generation (selection } \\
\text { bias) }\end{array}$ & Unclear risk & $\begin{array}{l}\text { "Stratified randomisation balanced gender and cocaine use fre- } \\
\text { quency." }\end{array}$ \\
\hline Allocation concealment (selection bias) & Unclear risk & Insufficient information to permit judgment. \\
\hline $\begin{array}{l}\text { Blinding (performance bias and detection } \\
\text { bias) } \\
\text { Patients and providers }\end{array}$ & Unclear risk & $\begin{array}{l}\text { No blinding but the outcome measurements are not likely to be } \\
\text { influenced by lack of blinding due to validation with physiolog- } \\
\text { ical measurement. }\end{array}$ \\
\hline $\begin{array}{l}\text { Blinding (performance bias and detection } \\
\text { bias) } \\
\text { Assessors }\end{array}$ & Low risk & $\begin{array}{l}\text { "Research assistants blind to treatment condition conducted as- } \\
\text { sessments." }\end{array}$ \\
\hline $\begin{array}{l}\text { Incomplete outcome data (attrition bias) } \\
\text { All outcomes }\end{array}$ & Unclear risk & $\begin{array}{l}10 \% \text { attrition at } 12 \text { months follow-up. We do not know the at- } \\
\text { trition at } 3 \text { and } 6 \text { months. Reasons for attrition unclear. Unclear } \\
\text { if attrition was balanced across groups. Use of ITT was reported, } \\
\text { but analyses were not reported with the full sample. }\end{array}$ \\
\hline
\end{tabular}


Rohsenow 2004 (Continued)

\begin{tabular}{|c|c|c|}
\hline Selective reporting (reporting bias) & Low risk & $\begin{array}{l}\text { The published report included all expected outcomes based on } \\
\text { the study hypotheses. }\end{array}$ \\
\hline Other bias & Unclear risk & $\begin{array}{l}\text { Urine drug screens and collateral reports to check on self-report. } \\
\text { The MET group reported drinking on more days at baseline. }\end{array}$ \\
\hline
\end{tabular}

Saitz 2007

\begin{tabular}{ll}
\hline Methods & RCT. \\
\hline Participants & 341 US medical inpatients who were drinking risky amounts of alcohol. \\
\hline Interventions & Motivational counselling $(\mathrm{n}=172)$ vs usual care $(\mathrm{n}=169)$. \\
\hline Outcomes & $\begin{array}{l}\text { Physiological primary: None. } \\
\text { Non-physiological primary: Drinking risky amounts, heavy drinking episodes, absti- } \\
\text { nence. } \\
\text { Secondary: Readiness to change (Taking Steps Scale on the Stages of Change Readiness } \\
\text { and Treatment Eagerness Scale). Data not reported. } \\
\text { Received alcohol assistance. }\end{array}$ \\
\hline Notes & \\
\hline
\end{tabular}

\section{Risk of bias}

\begin{tabular}{|c|c|c|}
\hline Bias & Authors' judgement & Support for judgement \\
\hline $\begin{array}{l}\text { Random sequence generation (selection } \\
\text { bias) }\end{array}$ & Unclear risk & $\begin{array}{l}\text { ”...permuted block (size } 8 \text { ) randomisation procedure stratified } \\
\text { by AUDIT score." }\end{array}$ \\
\hline Allocation concealment (selection bias) & Unclear risk & $\begin{array}{l}\text { Used sealed opaque envelopes. It is unclear whether the en- } \\
\text { velopes were opaque and/or sequentially numbered. }\end{array}$ \\
\hline $\begin{array}{l}\text { Blinding (performance bias and detection } \\
\text { bias) } \\
\text { Patients and providers }\end{array}$ & High risk & No blinding. \\
\hline
\end{tabular}

Blinding (performance bias and detection Unclear risk bias)

Assessors

Incomplete outcome data (attrition bias) Low risk All outcomes
It is not stated whether the assessors were blinded.

At 3 months follow-up, the attrition was $17 \%$ in the usual care group and $24 \%$ in the brief intervention group. At 12 months, the attrition was $14 \%$ in the usual care group and $18 \%$ in the brief intervention group. Flow chart with reasons for attrition reported. It appears that ITT was performed ("...analyzed all patients in the groups to which they were randomly assigned.) 
Saitz 2007 (Continued)

\begin{tabular}{|c|c|c|}
\hline Selective reporting (reporting bias) & Low risk & $\begin{array}{l}\text { The published report included all expected outcomes based on } \\
\text { the study hypotheses. }\end{array}$ \\
\hline Other bias & Unclear risk & $\begin{array}{l}\text { Baseline imbalances (gender, alcohol-attributable medical diag- } \\
\text { noses, received alcohol assistance, drug use) existed despite ran- } \\
\text { domization. Biological breath tests were conducted at follow- } \\
\text { ups. }\end{array}$ \\
\hline
\end{tabular}

Schaus 2009

\begin{tabular}{ll}
\hline Methods & RCT. \\
\hline Participants & 363 college students who screened positive for high-risk drinking. USA. \\
\hline Interventions & MI + a brochure $(\mathrm{n}=181)$ vs a control group receiving only the brochure $(\mathrm{n}=182)$. \\
\hline Outcomes & $\begin{array}{l}\text { Physiological primary: None. } \\
\text { Non-physiological primary: Typical BAC, peak BAC, average number of drinks per } \\
\text { sitting, number of days with heavy episodic drinking, peak number of drinks in one } \\
\text { sitting, average number of drinks per week, and number of times drunk in a typical } \\
\text { week. } \\
\text { Secondary: Readiness to change (Readiness to Change Questionnaire). } \\
\text { Follow-ups were at 3, 6, 9, and } 12 \text { months. }\end{array}$ \\
\hline Notes & \\
\hline
\end{tabular}

\section{Risk of bias}

\section{Bias}

Random sequence generation (selection Unclear risk bias)

\section{Authors' judgement Support for judgement}

"Subjects were block randomised using SPSS Version 15.0 ...to either the control or intervention group, where the order of the interventions varied randomly within each block."

\begin{tabular}{ll}
\hline Allocation concealment (selection bias) N Unclear risk & $\begin{array}{l}\text { "The group assignment was placed into a sealed envelope by the } \\
\text { data manager and was not available to those recruiting subjects } \\
\text { until after informed consent was obtained." }\end{array}$
\end{tabular}

Blinding (performance bias and detection High risk No blinding. bias)

Patients and providers

Blinding (performance bias and detection Unclear risk bias)

Assessors
It is not stated whether the assessors were blinded. 
Schaus 2009 (Continued)

\begin{tabular}{|c|c|c|}
\hline $\begin{array}{l}\text { Incomplete outcome data (attrition bias) } \\
\text { All outcomes }\end{array}$ & High risk & $\begin{array}{l}\text { Percent lost to follow-up after } 3,6,9 \text {, and } 12 \text { months were } 24 \% \text {, } \\
42 \%, 41 \% \text {, and } 35 \% \text {, respectively. Follow-up did not differ sig- } \\
\text { nificantly between groups. Reasons for attrition not provided. } \\
\text { ITT probably performed. }\end{array}$ \\
\hline Selective reporting (reporting bias) & Low risk & $\begin{array}{l}\text { The published report included all expected outcomes based on } \\
\text { the study hypotheses. }\end{array}$ \\
\hline Other bias & High risk & $\begin{array}{l}\text { Only self-reported outcomes. The variable "number of } \\
\text { times drove after } \geq 3 \text { drinks." was higher in the control group at } \\
\text { baseline. }\end{array}$ \\
\hline
\end{tabular}

Sellman 2001

\begin{tabular}{ll}
\hline Methods & RCT. \\
\hline Participants & 125 patients from New Zealand with mild to moderate alcohol dependence. \\
\hline Interventions & $\begin{array}{l}\text { 1. MET }(\mathrm{n}=42) \\
\text { 2. non-directive reflective listening }(\mathrm{n}=40) \\
\text { 3. no further counselling }(\mathrm{n}=40) .\end{array}$ \\
\hline
\end{tabular}

Outcomes

Physiological primary: None.

Non-physiological primary: Broke abstinence, exceeded national guidelines at least once, exceeded national guidelines six or more times, drank 10+ standard drinks at least once, drank 10+ standard drink six or more times.

Secondary: None.

Notes

Risk of bias

\begin{tabular}{|c|c|c|}
\hline Bias & Authors' judgement & Support for judgement \\
\hline $\begin{array}{l}\text { Random sequence generation (selection } \\
\text { bias) }\end{array}$ & Unclear risk & “...randomly constructed list of therapies." \\
\hline Allocation concealment (selection bias) & Low risk & $\begin{array}{l}\text { "An administrative person who was independent of the assess- } \\
\text { ment and treatment of the study was contacted regarding the } \\
\text { therapy to be undertaken." }\end{array}$ \\
\hline $\begin{array}{l}\text { Blinding (performance bias and detection } \\
\text { bias) } \\
\text { Patients and providers }\end{array}$ & Unclear risk & $\begin{array}{l}\text { Blinding of providers was not possible, but participants could } \\
\text { have been blinded. }\end{array}$ \\
\hline $\begin{array}{l}\text { Blinding (performance bias and detection } \\
\text { bias) } \\
\text { Assessors }\end{array}$ & Low risk & $\begin{array}{l}\text { "A senior research assistant, who was blind to the treatment } \\
\text { received, successfully completed follow-up." }\end{array}$ \\
\hline
\end{tabular}

Motivational interviewing for substance abuse (Review)

Copyright (@) 20II The Cochrane Collaboration. Published by John Wiley \& Sons, Ltd. 
Sellman 2001 (Continued)

\begin{tabular}{|c|c|c|}
\hline $\begin{array}{l}\text { Incomplete outcome data (attrition bias) } \\
\text { All outcomes }\end{array}$ & Low risk & $\begin{array}{l}1 \% \text { attrition at } 6 \text { months follow-up. Attrition was balanced } \\
\text { across conditions, but no reasons were reported. It is unclear } \\
\text { whether ITT was performed. }\end{array}$ \\
\hline Selective reporting (reporting bias) & Low risk & $\begin{array}{l}\text { The published report included all expected outcomes based on } \\
\text { the study hypotheses. }\end{array}$ \\
\hline Other bias & Low risk & $\begin{array}{l}\text { Collateral to check on self-report. There were differences be- } \\
\text { tween groups at baseline for GAS score. No additional sources } \\
\text { of bias appear to be present. }\end{array}$ \\
\hline
\end{tabular}

Stein 2002

\begin{tabular}{ll} 
Methods & RCT. \\
\hline Participants & 187 US AUDIT-positive active injection drug users. \\
\hline Interventions & MI $(\mathrm{n}=95)$ vs control (assessment only) $(\mathrm{n}=92)$. \\
\hline Outcomes & $\begin{array}{l}\text { Physiological primary: None. } \\
\text { Non-physiological primary: Number of drinking days. } \\
\text { Secondary: None. }\end{array}$ \\
\hline Notes & BRAINE study. \\
\hline
\end{tabular}

\section{Risk of bias}

\begin{tabular}{|c|c|c|}
\hline Bias & Authors' judgement & Support for judgement \\
\hline $\begin{array}{l}\text { Random sequence generation (selection } \\
\text { bias) }\end{array}$ & Unclear risk & $\begin{array}{l}\text { "Subjects were assigned to treatments using a randomisation } \\
\text { schedule created with permuted blocks of eight assignments." }\end{array}$ \\
\hline Allocation concealment (selection bias) & Unclear risk & $\begin{array}{l}\text { "The data manager prepared the randomisation schedule before } \\
\text { the first patient enrolled." }\end{array}$ \\
\hline $\begin{array}{l}\text { Blinding (performance bias and detection } \\
\text { bias) } \\
\text { Patients and providers }\end{array}$ & High risk & No blinding. \\
\hline $\begin{array}{l}\text { Blinding (performance bias and detection } \\
\text { bias) } \\
\text { Assessors }\end{array}$ & Low risk & $\begin{array}{l}\text { "At each follow-up assessment, research assistants were blinded } \\
\text { to the treatment condition of the subject." }\end{array}$ \\
\hline $\begin{array}{l}\text { Incomplete outcome data (attrition bias) } \\
\text { All outcomes }\end{array}$ & Low risk & $\begin{array}{l}3 \% \text { loss to follow-up at } 6 \text { months. Balanced. No reasons pro- } \\
\text { vided. ITT performed. Missing data were imputed using a 'worst } \\
\text { case scenario' strategy. }\end{array}$ \\
\hline
\end{tabular}


Stein 2002 (Continued)

\begin{tabular}{|c|c|c|}
\hline Selective reporting (reporting bias) & Low risk & $\begin{array}{l}\text { The published report included all expected outcomes based on } \\
\text { the study hypotheses. }\end{array}$ \\
\hline Other bias & Unclear risk & $\begin{array}{l}\text { Only self-reported outcomes. There were no differences between } \\
\text { groups at baseline. }\end{array}$ \\
\hline
\end{tabular}

Stein 2009

\begin{tabular}{ll}
\hline Methods & RCT. \\
\hline Participants & 198 persons who used cocaine at least weekly and who were not in treatment. USA. \\
\hline Interventions & $\begin{array}{l}\text { 4-session motivational intervention ( } \mathrm{n}=97) \text { or an assessment only control group (n= } \\
\text { 101). Both groups received a written handout list of treatment resources. Each session } \\
\text { lasted } 20 \text { to } 40 \text { minutes. }\end{array}$ \\
\hline Outcomes & $\begin{array}{l}\text { Physiological primary: None. } \\
\text { Non-physiological primary: Any reduction in cocaine use, more than 50\% reduction, } \\
\text { and abstinence. } \\
\text { Secondary: Treatment attendance (inpatient therapy, attended NA or CA, any drug } \\
\text { treatment). } \\
\text { Follow-up at } 6 \text { months. }\end{array}$ \\
\hline Notes & \\
\hline
\end{tabular}

\section{Risk of bias}

Bias

\section{Authors' judgement Support for judgement}

Random sequence generation (selection Unclear risk bias)

\begin{tabular}{|c|c|c|}
\hline Allocation concealment (selection bias) & Unclear risk & $\begin{array}{l}\text { "Randomization and concealment were overseen by the study } \\
\text { methodologist." }\end{array}$ \\
\hline $\begin{array}{l}\text { Blinding (performance bias and detection } \\
\text { bias) } \\
\text { Patients and providers }\end{array}$ & High risk & No blinding. \\
\hline $\begin{array}{l}\text { Blinding (performance bias and detection } \\
\text { bias) } \\
\text { Assessors }\end{array}$ & Low risk & $\begin{array}{l}\text { "Follow-up interviews were performed by research staff blinded } \\
\text { to study conditions." }\end{array}$ \\
\hline $\begin{array}{l}\text { Incomplete outcome data (attrition bias) } \\
\text { All outcomes }\end{array}$ & Low risk & $\begin{array}{l}\text { ITT performed. Attrition was } 19 \% \text { at } 6 \text { months. Reasons not } \\
\text { stated. }\end{array}$ \\
\hline Selective reporting (reporting bias) & Low risk & $\begin{array}{l}\text { The published report included all expected outcomes based on } \\
\text { the study hypotheses. }\end{array}$ \\
\hline
\end{tabular}

Motivational interviewing for substance abuse (Review)

Copyright (@) 20II The Cochrane Collaboration. Published by John Wiley \& Sons, Ltd.

"Randomization and concealment were overseen by the study methodologist." the study hypotheses. 
Stein 2009 (Continued)

\begin{tabular}{|c|c|c|}
\hline Other bias & Unclear risk & $\begin{array}{l}\text { Only self-reported outcomes. There were no differences between } \\
\text { groups at baseline. }\end{array}$ \\
\hline
\end{tabular}

\section{Stein 2010}

\begin{tabular}{|c|c|c|}
\hline Methods & \multicolumn{2}{|l|}{ RCT. } \\
\hline Participants & \multicolumn{2}{|c|}{245 incarcerated women with hazardous drinking. } \\
\hline Interventions & \multicolumn{2}{|c|}{ MI ( $n=125)$ vs assessment only $(n=120)$. } \\
\hline Outcomes & \multicolumn{2}{|c|}{$\begin{array}{l}\text { 90-day drinking (probability of an abstinent day, drinks per drinking day) using Timeline } \\
\text { Followback at 1, } 3 \text { and } 6 \text { months follow-up. }\end{array}$} \\
\hline \multicolumn{3}{|l|}{ Notes } \\
\hline \multicolumn{3}{|l|}{ Risk of bias } \\
\hline Bias & Authors' judgement & Support for judgement \\
\hline $\begin{array}{l}\text { Random sequence generation (selection } \\
\text { bias) }\end{array}$ & Unclear risk & $\begin{array}{l}\text { "Randomization and concealment were overseen by the study } \\
\text { methodologist (B.J.A.)". }\end{array}$ \\
\hline Allocation concealment (selection bias) & Unclear risk & $\begin{array}{l}\text { "Randomization and concealment were overseen by the study } \\
\text { methodologist (B.J.A.)". }\end{array}$ \\
\hline $\begin{array}{l}\text { Blinding (performance bias and detection } \\
\text { bias) } \\
\text { Patients and providers }\end{array}$ & High risk & Patients and providers were not blinded to the interventions. \\
\hline $\begin{array}{l}\text { Blinding (performance bias and detection } \\
\text { bias) } \\
\text { Assessors }\end{array}$ & Low risk & $\begin{array}{l}\text { “...research staff performing the assessments were blinded to the } \\
\text { participant's assigned } \\
\text { condition." }\end{array}$ \\
\hline $\begin{array}{l}\text { Incomplete outcome data (attrition bias) } \\
\text { All outcomes }\end{array}$ & High risk & $\begin{array}{l}\text { Attrition was } 24 \% \text { at } 1 \text { month, } 21 \% \text { at } 3 \text { months and } 21 \% \text { at } 6 \\
\text { months. Balanced. Not ITT. No reasons. }\end{array}$ \\
\hline Selective reporting (reporting bias) & Low risk & $\begin{array}{l}\text { The published report included all expected outcomes based on } \\
\text { the study hypotheses. }\end{array}$ \\
\hline Other bias & Unclear risk & $\begin{array}{l}\text { Only self-reported outcomes. There were no differences between } \\
\text { groups at baseline. }\end{array}$ \\
\hline
\end{tabular}


Stephens 2007

\begin{tabular}{|c|c|c|}
\hline Methods & \multicolumn{2}{|l|}{ RCT. } \\
\hline Participants & \multicolumn{2}{|c|}{188 US marijuana users. } \\
\hline Interventions & \multicolumn{2}{|c|}{$\begin{array}{l}\text { 1. Personalized feedback (utilising MI) }(n=62) \\
\text { 2. educational control (multi-media feedback) }(n=62) \\
\text { 3. delayed feedback }(n=64) \text {. }\end{array}$} \\
\hline Outcomes & \multicolumn{2}{|c|}{$\begin{array}{l}\text { Physiological primary: None. } \\
\text { Non-physiological primary: Days of marijuana use per week, periods smoked per day } \\
\text { dependence symptoms. } \\
\text { Secondary: Motivation (Readiness to Change Questionnaire). Data not reported. }\end{array}$} \\
\hline \multicolumn{3}{|l|}{ Notes } \\
\hline \multicolumn{3}{|l|}{ Risk of bias } \\
\hline Bias & Authors' judgement & Support for judgement \\
\hline $\begin{array}{l}\text { Random sequence generation (selection } \\
\text { bias) }\end{array}$ & Low risk & Used an urn randomisation program. \\
\hline Allocation concealment (selection bias) & Unclear risk & Insufficient information to permit judgment. \\
\hline $\begin{array}{l}\text { Blinding (performance bias and detection } \\
\text { bias) } \\
\text { Patients and providers }\end{array}$ & Unclear risk & $\begin{array}{l}\text { No blinding but the outcome measurements are not likely to be } \\
\text { influenced by lack of blinding due to validation with physiolog- } \\
\text { ical measurement. }\end{array}$ \\
\hline $\begin{array}{l}\text { Blinding (performance bias and detection } \\
\text { bias) } \\
\text { Assessors }\end{array}$ & Low risk & “...research staff...was not aware of assigned condition”. \\
\hline $\begin{array}{l}\text { Incomplete outcome data (attrition bias) } \\
\text { All outcomes }\end{array}$ & Low risk & $\begin{array}{l}\text { Attrition was } 5 \% \text { at } 7 \text { weeks, } 10 \% \text { at } 6 \text { months, and } 19 \% \text { at } 12 \\
\text { months follow-up. Balanced across conditions. No reasons. ITT } \\
\text { probably performed (missing data were replaced with baseline } \\
\text { values). }\end{array}$ \\
\hline Selective reporting (reporting bias) & Low risk & $\begin{array}{l}\text { The published report included all expected outcomes based on } \\
\text { the study hypotheses. }\end{array}$ \\
\hline Other bias & Low risk & $\begin{array}{l}\text { Urine specimens were collected at each assessment point and } \\
\text { analysed for the presence of drug metabolites via enzyme im- } \\
\text { munoassay tests. Differences between groups at baseline were } \\
\text { not reported. No additional sources of bias appear to be present. }\end{array}$ \\
\hline
\end{tabular}


Stotts 2001

\begin{tabular}{ll}
\hline Methods & RCT. \\
\hline Participants & $\begin{array}{l}105 \text { US cocaine-dependent men and women aged 18-50 years admitted to a university } \\
\text { medical centre. }\end{array}$ \\
\hline Interventions & $\begin{array}{l}\text { MI vs detox-only. The group sizes were not reported. The detox only conditions was } \\
\text { ".... multi component intervention consisting of daily visits, interaction with research } \\
\text { assistants, education, and graphing and feedback of daily urine results, as well as bonus } \\
\text { money and further treatment contingent on successful completion of the program." }\end{array}$ \\
\hline
\end{tabular}

\begin{tabular}{ll} 
Outcomes & $\begin{array}{l}\text { Physiological primary: Cocaine-positive urine samples. } \\
\text { Non-physiological primary: Cocaine use. } \\
\text { Secondary: Treatment retention (completion of detox program). } \\
\text { Readiness to change (Processes of Change Scale). }\end{array}$ \\
\hline Notes & $\begin{array}{l}\text { We sent an email on April 29th } 2010 \text { requesting the group sizes. On June 4th we } \\
\text { contacted Brad Lundahl, author of a systematic review for effect size information. He } \\
\text { gave us effect size data. }\end{array}$
\end{tabular}

\section{Risk of bias}

\begin{tabular}{|c|c|c|}
\hline Bias & Authors' judgement & Support for judgement \\
\hline $\begin{array}{l}\text { Random sequence generation (selection } \\
\text { bias) }\end{array}$ & Unclear risk & "...randomly assigned..." \\
\hline Allocation concealment (selection bias) & Unclear risk & "...randomly assigned..." \\
\hline $\begin{array}{l}\text { Blinding (performance bias and detection } \\
\text { bias) } \\
\text { Patients and providers }\end{array}$ & Low risk & $\begin{array}{l}\text { No blinding, but most outcomes were physiological and also } \\
\text { used to validate self-reports, and not likely to be influenced by } \\
\text { lack of blinding. }\end{array}$ \\
\hline $\begin{array}{l}\text { Blinding (performance bias and detection } \\
\text { bias) } \\
\text { Assessors }\end{array}$ & Low risk & $\begin{array}{l}\text { Insufficient information to know whether assessors were } \\
\text { blinded. But most outcomes were physiological and also used to } \\
\text { validate self-reports, and not likely to be influenced by lack of } \\
\text { blinding. }\end{array}$ \\
\hline $\begin{array}{l}\text { Incomplete outcome data (attrition bias) } \\
\text { All outcomes }\end{array}$ & High risk & $\begin{array}{l}\text { Intention to treat of the full sample }(\mathrm{N}=105) \text { were conducted on } \\
\text { completion of the DP. The number of participants randomised } \\
\text { to each condition is not reported. Analysis of urine samples were } \\
\text { conducted on } 51 \text { completers. }\end{array}$ \\
\hline Selective reporting (reporting bias) & Low risk & $\begin{array}{l}\text { The published report included all expected outcomes based on } \\
\text { the study hypotheses. }\end{array}$ \\
\hline Other bias & Low risk & $\begin{array}{l}\text { Urineanalysis to validate self-report. There were no differences } \\
\text { between groups at baseline. No additional sources of bias appear } \\
\text { to be present. }\end{array}$ \\
\hline
\end{tabular}


Stotts 2006

\begin{tabular}{ll}
\hline Methods & Pilot RCT. \\
\hline Participants & 31 male treatment-seeking cocaine abusers. USA. \\
\hline Interventions & $\begin{array}{l}\text { Two-session MI intervention with informative biological EEG/ERP feedback ( } \mathrm{n}=17) \text { or } \\
\text { a minimal control condition who had two brief meetings with an experienced research } \\
\text { assistant weekly over two weeks }(\mathrm{n}=14) .\end{array}$ \\
\hline
\end{tabular}

Outcomes

Physiological primary: Cocaine-positive urine screens.

Non-physiological primary: Proportion of self-reported cocaine use days.

Secondary: Readiness to change (URICA). Data not reported.

\section{Notes}

\section{Risk of bias}

Bias

Random sequence generation (selection Unclear risk bias)

\begin{tabular}{|c|c|c|}
\hline Allocation concealment (selection bias) & Unclear risk & Insufficient information to permit judgement. \\
\hline $\begin{array}{l}\text { Blinding (performance bias and detection } \\
\text { bias) } \\
\text { Patients and providers }\end{array}$ & Low risk & $\begin{array}{l}\text { No blinding, but most outcomes were physiological and also } \\
\text { used to validate self-reports, and not likely to be influenced by } \\
\text { lack of blinding. }\end{array}$ \\
\hline $\begin{array}{l}\text { Blinding (performance bias and detection } \\
\text { bias) } \\
\text { Assessors }\end{array}$ & Low risk & $\begin{array}{l}\text { "Posttreatment assessment was conducted at 1-week post-study } \\
\text { by clinic staff blind to study condition." }\end{array}$ \\
\hline $\begin{array}{l}\text { Incomplete outcome data (attrition bias) } \\
\text { All outcomes }\end{array}$ & Unclear risk & $\begin{array}{l}\text { Only subjects with data at both time points were analysed ( } 27 / \\
31=13 \% \text { attrition). Reasons for missing data not reported. ITT } \\
\text { not performed. }\end{array}$ \\
\hline Selective reporting (reporting bias) & Low risk & $\begin{array}{l}\text { The published report included all expected outcomes based on } \\
\text { the study hypotheses. }\end{array}$ \\
\hline Other bias & Low risk & $\begin{array}{l}\text { EEG screening to validate self-report. There were no differences } \\
\text { between groups at baseline. No additional sources of bias appear } \\
\text { to be present. }\end{array}$ \\
\hline
\end{tabular}


Thush 2009

\begin{tabular}{ll}
\hline Methods & RCT. \\
\hline Participants & 125 Dutch at-risk adolescents. \\
\hline Interventions & MI plus information flyers (n=61) vs information flyers only (n=64). \\
\hline Outcomes & $\begin{array}{l}\text { Physiological primary: None. } \\
\text { Non-physiological primary: Alcohol use. } \\
\text { Secondary: Readiness to change using a readiness-to-change ruler. Data not reported. } \\
\text { Follow-ups at } 1 \text { month and } 6 \text { months. }\end{array}$ \\
\hline Notes & $\begin{array}{l}\text { Email sent to Thush requesting raw outcome data on May 28th 2010. Thush replied } \\
\text { immediately promising to look into it. They have computed a log transformed standard- } \\
\text { ized alcohol use index score out of six different correlated alcohol use outcome measures. } \\
\text { A reminder was sent on August 30th. An out of office reply informed that Thush had } \\
\text { resigned. }\end{array}$ \\
\hline
\end{tabular}

\section{Risk of bias}

\begin{tabular}{|c|c|c|}
\hline Bias & Authors' judgement & Support for judgement \\
\hline $\begin{array}{l}\text { Random sequence generation (selection } \\
\text { bias) }\end{array}$ & Unclear risk & "randomly assigned" \\
\hline Allocation concealment (selection bias) & Unclear risk & Insufficient information to permit judgement. \\
\hline $\begin{array}{l}\text { Blinding (performance bias and detection } \\
\text { bias) } \\
\text { Patients and providers }\end{array}$ & High risk & No blinding. \\
\hline $\begin{array}{l}\text { Blinding (performance bias and detection } \\
\text { bias) } \\
\text { Assessors }\end{array}$ & Unclear risk & It is not stated whether assessors were blinded. \\
\hline $\begin{array}{l}\text { Incomplete outcome data (attrition bias) } \\
\text { All outcomes }\end{array}$ & High risk & $\begin{array}{l}10 \% \text { lost to follow-up at } 1 \text { month and } 41 \% \text { lost to follow-up } \\
\text { at } 6 \text { months. Reasons not provided. Balanced at } 1 \text { month. Not } \\
\text { known whether loss was balanced at } 6 \text { months. Not ITT. }\end{array}$ \\
\hline Selective reporting (reporting bias) & Low risk & $\begin{array}{l}\text { The published report included all expected outcomes based on } \\
\text { the study hypotheses. }\end{array}$ \\
\hline Other bias & Unclear risk & $\begin{array}{l}\text { Only self-reported outcomes. Differences between groups at } \\
\text { baseline were not reported. }\end{array}$ \\
\hline
\end{tabular}


UKATT 2005

\begin{tabular}{|c|c|c|}
\hline Methods & \multicolumn{2}{|l|}{ Multisite RCT (7 sites). } \\
\hline Participants & \multicolumn{2}{|c|}{742 UK clients with alcohol problems. } \\
\hline Interventions & \multicolumn{2}{|c|}{$\operatorname{MET}(n=442)$ vs social behavior and network therapy $(n=320)$. } \\
\hline Outcomes & \multicolumn{2}{|c|}{$\begin{array}{l}\text { Physiological primary: Gamma-glutamyl transferase } \\
\text { Non-physiological primary: Days abstinent, number of drinks per drinking day, Leeds } \\
\text { Dependence Questionnaire score, alcohol problems score. } \\
\text { Secondary: None. }\end{array}$} \\
\hline \multicolumn{3}{|l|}{ Notes } \\
\hline \multicolumn{3}{|l|}{ Risk of bias } \\
\hline Bias & Authors' judgement & Support for judgement \\
\hline $\begin{array}{l}\text { Random sequence generation (selection } \\
\text { bias) }\end{array}$ & Low risk & $\begin{array}{l}\text { "The remote randomisation service at York used a computer } \\
\text { "on line" to allocate consenting participants between therapy } \\
\text { groups." }\end{array}$ \\
\hline Allocation concealment (selection bias) & Unclear risk & "Treatment was concealed until allocation." \\
\hline $\begin{array}{l}\text { Blinding (performance bias and detection } \\
\text { bias) } \\
\text { Patients and providers }\end{array}$ & Low risk & $\begin{array}{l}\text { No blinding, but most outcomes were physiological and also } \\
\text { used to validate self-reports, and not likely to be influenced } \\
\text { by lack of blinding. }\end{array}$ \\
\hline $\begin{array}{l}\text { Blinding (performance bias and detection } \\
\text { bias) } \\
\text { Assessors }\end{array}$ & Low risk & $\begin{array}{l}\text { Assessors blinded at } 12 \text { months but not at } 3 \text { months. But most } \\
\text { outcomes were physiological and also used to validate self- } \\
\text { reports, and not likely to be influenced by lack of blinding. }\end{array}$ \\
\hline $\begin{array}{l}\text { Incomplete outcome data (attrition bias) } \\
\text { All outcomes }\end{array}$ & Low risk & $\begin{array}{l}7 \% \text { attrition at } 3 \text { months follow-up and } 17 \% \text { attrition at } 12 \\
\text { months follow-up. Balanced. Reasons provided. ITT using } \\
\text { last observation carried forward performed. }\end{array}$ \\
\hline Selective reporting (reporting bias) & Low risk & $\begin{array}{l}\text { The published report included all expected outcomes based } \\
\text { on the study hypotheses. }\end{array}$ \\
\hline Other bias & Low risk & $\begin{array}{l}\text { Gamma GT used to check on self-report. There were no } \\
\text { differences between groups at baseline. No additional sources } \\
\text { of bias appear to be present. }\end{array}$ \\
\hline
\end{tabular}


Walitzer 2008

\begin{tabular}{|c|c|c|}
\hline Methods & \multicolumn{2}{|l|}{ RCT. } \\
\hline Participants & \multicolumn{2}{|c|}{169 alcoholic outpatients. USA. } \\
\hline Interventions & \multicolumn{2}{|c|}{$\begin{array}{l}\text { (1) a motivational approach to facilitating AA }(\mathrm{n}=58),(2) \text { a } 12 \text {-step directive approach } \\
\text { to facilitating AA ( } \mathrm{n}=53) \text {, or }(3) \text { treatment as usual with no special emphasis on AA ( }= \\
\text { 58). All conditions received } 12 \text { sessions. }\end{array}$} \\
\hline Outcomes & \multicolumn{2}{|c|}{$\begin{array}{l}\text { Physiological primary: None. } \\
\text { Non-physiological primary: Percentage of days abstinent, percentage of days heavy } \\
\text { drinking via the Timeline Followback. } \\
\text { Secondary: Attendance at AA meetings. }\end{array}$} \\
\hline Notes & \multicolumn{2}{|c|}{$\begin{array}{l}\text { On } 11 \text { October } 2010 \text { we sent an email to Kim Walitzer (walitzer@ria.buffalo.edu) re- } \\
\text { questing data on retention in treatment. }\end{array}$} \\
\hline \multicolumn{3}{|l|}{ Risk of bias } \\
\hline Bias & Authors' judgement & Support for judgement \\
\hline $\begin{array}{l}\text { Random sequence generation (selection } \\
\text { bias) }\end{array}$ & Low risk & $\begin{array}{l}\text { "Random assignment to conditions was conducted by the third } \\
\text { author via urn randomisation...". }\end{array}$ \\
\hline Allocation concealment (selection bias) & Unclear risk & $\begin{array}{l}\text { "Random assignment to conditions was conducted by the third } \\
\text { author via urn randomisation...". Insufficient information to } \\
\text { permit judgement. }\end{array}$ \\
\hline $\begin{array}{l}\text { Blinding (performance bias and detection } \\
\text { bias) } \\
\text { Patients and providers }\end{array}$ & Unclear risk & $\begin{array}{l}\text { Blinding of providers was not possible, but participants could } \\
\text { have been blinded. }\end{array}$ \\
\hline $\begin{array}{l}\text { Blinding (performance bias and detection } \\
\text { bias) } \\
\text { Assessors }\end{array}$ & Low risk & "Research interviewers were blind to intervention condition." \\
\hline $\begin{array}{l}\text { Incomplete outcome data (attrition bias) } \\
\text { All outcomes }\end{array}$ & Unclear risk & $\begin{array}{l}10 \% \text { attrition on interview and } 15 \% \text { on questionnaire data. No } \\
\text { reasons stated. Similar across conditions. Not ITT in primary } \\
\text { analysis. }\end{array}$ \\
\hline Selective reporting (reporting bias) & Low risk & $\begin{array}{l}\text { The published report included all expected outcomes based on } \\
\text { the study hypotheses. }\end{array}$ \\
\hline Other bias & Low risk & $\begin{array}{l}\text { Used collateral interviews to check on self-report. Differences } \\
\text { between groups at baseline were not reported. No additional } \\
\text { sources of bias appear to be present. }\end{array}$ \\
\hline
\end{tabular}


Walker 2006

\begin{tabular}{|c|c|c|}
\hline Methods & \multicolumn{2}{|l|}{ Multisite RCT (4 sites). } \\
\hline Participants & \multicolumn{2}{|l|}{97 US adolescents. } \\
\hline Interventions & \multicolumn{2}{|c|}{2 session MET $(n=47)$ vs 3 months delayed condition $(n=50)$. } \\
\hline Outcomes & \multicolumn{2}{|c|}{$\begin{array}{l}\text { Physiological primary: None. } \\
\text { Non-physiological primary: Number of days of marijuana use. } \\
\text { Secondary: None. }\end{array}$} \\
\hline \multicolumn{3}{|l|}{ Notes } \\
\hline \multicolumn{3}{|l|}{ Risk of bias } \\
\hline Bias & Authors' judgement & Support for judgement \\
\hline $\begin{array}{l}\text { Random sequence generation (selection } \\
\text { bias) }\end{array}$ & Unclear risk & “...randomly assigned.” \\
\hline Allocation concealment (selection bias) & Unclear risk & Insufficient information to permit judgment. \\
\hline $\begin{array}{l}\text { Blinding (performance bias and detection } \\
\text { bias) } \\
\text { Patients and providers }\end{array}$ & High risk & No blinding. \\
\hline $\begin{array}{l}\text { Blinding (performance bias and detection } \\
\text { bias) } \\
\text { Assessors }\end{array}$ & Unclear risk & $\begin{array}{l}\text { "Baseline and 3-month follow-up assessments were admin- } \\
\text { istered by an audio-computer-assisted self-interviewing pro- } \\
\text { gram." But "a different HE (health educator) was assigned to } \\
\text { conduct the follow-up." }\end{array}$ \\
\hline $\begin{array}{l}\text { Incomplete outcome data (attrition bias) } \\
\text { All outcomes }\end{array}$ & Unclear risk & $\begin{array}{l}\text { Attrition was } 5 \% \text { overall at } 3 \text { months follow-up ( } 9 \% \text { in the } \\
\text { MET group and } 2 \% \text { in the DFC group). Unbalanced across } \\
\text { conditions. Reasons not reported. Stated use of ITT but re- } \\
\text { ported only actual data. }\end{array}$ \\
\hline Selective reporting (reporting bias) & High risk & $\begin{array}{l}\text { Authors stated alcohol and other drugs as outcomes but re- } \\
\text { ported only marijuana use in the results. Some results were } \\
\text { only claimed as "not significant" but not reported explicitly. }\end{array}$ \\
\hline Other bias & Unclear risk & $\begin{array}{l}\text { Only self-reported outcomes. There were more whites in the } \\
\text { immediate treatment group than in the delayed treatment } \\
\text { group at baseline. }\end{array}$ \\
\hline
\end{tabular}


Walters 2009

\begin{tabular}{ll}
\hline Methods & Dismantling RCT. \\
\hline Participants & 279 heavy drinking college students. USA. \\
\hline Interventions & $\begin{array}{l}\text { (1) A single MI session without feedback (MIO, } \mathrm{n}=70),(2) \text { a single MI session with } \\
\text { feedback (MIF, } \mathrm{n}=73),(3) \text { web feedback only }(\mathrm{FBO}, \mathrm{n}=67), \text { or (4) assessment only (AO, } \\
\mathrm{n}=69) .\end{array}$
\end{tabular}

Outcomes

Physiological primary: None.

Non-physiological primary: Drinks per week, estimated peak BAC.

Secondary: None.

Notes

\section{Risk of bias}

\begin{tabular}{|c|c|c|}
\hline Bias & Authors' judgement & Support for judgement \\
\hline $\begin{array}{l}\text { Random sequence generation (selection } \\
\text { bias) }\end{array}$ & Unclear risk & $\begin{array}{l}\text { "Randomization, stratified by sex and heavy-drinking frequency } \\
\text { (i.e., one heavy episode in the past } 2 \text { weeks vs. more than one } \\
\text { heavy episode), was completed automatically after the students } \\
\text { entered their screening data." }\end{array}$ \\
\hline Allocation concealment (selection bias) & Unclear risk & Insufficient information to permit judgement. \\
\hline $\begin{array}{l}\text { Blinding (performance bias and detection } \\
\text { bias) } \\
\text { Patients and providers }\end{array}$ & High risk & No blinding. \\
\hline $\begin{array}{l}\text { Blinding (performance bias and detection } \\
\text { bias) } \\
\text { Assessors }\end{array}$ & Unclear risk & It is not stated whether assessors were blinded. \\
\hline $\begin{array}{l}\text { Incomplete outcome data (attrition bias) } \\
\text { All outcomes }\end{array}$ & Unclear risk & $\begin{array}{l}10 \% \text { attrition at } 3 \text { months and } 14 \% \text { attrition at } 6 \text { months. Dif- } \\
\text { ferent across groups. No reasons. ITT not conducted. }\end{array}$ \\
\hline Selective reporting (reporting bias) & Low risk & $\begin{array}{l}\text { The published report included all expected outcomes based on } \\
\text { the study hypotheses. }\end{array}$ \\
\hline Other bias & Unclear risk & $\begin{array}{l}\text { The feedback format varied (i. e. online vs. face-to-face) and } \\
\text { MIO and MIF conditions varied in contact time because of the } \\
\text { feedback component. There were no differences between groups } \\
\text { at baseline. }\end{array}$ \\
\hline
\end{tabular}


White 2006

\begin{tabular}{|c|c|c|}
\hline Methods & \multicolumn{2}{|l|}{ RCT. } \\
\hline Participants & \multicolumn{2}{|c|}{222 mandated college students. USA. } \\
\hline Interventions & \multicolumn{2}{|c|}{ Brief motivational interview $(\mathrm{n}=180)$ vs written feedback only $(\mathrm{n}=168)$. } \\
\hline Outcomes & \multicolumn{2}{|c|}{$\begin{array}{l}\text { Physiological primary: None. } \\
\text { Non-physiological primary: Past month alcohol frequency, number of occasions of } \\
\text { heavy episodic drinking, number of drinks and number of hours of drinking each day } \\
\text { in a typical week in the last month. Frequency of marijuana use in the past month. } \\
\text { Secondary: None. } \\
\text { Follow-up at } 3 \text { months post-intervention. }\end{array}$} \\
\hline Notes & \multicolumn{2}{|c|}{$\begin{array}{l}\text { White } 2007 \text { is the same study with further recruitment ( } n=348) \text {. The follow-ups were } \\
\text { at } 4 \text { and } 15 \text { months. }\end{array}$} \\
\hline \multicolumn{3}{|l|}{ Risk of bias } \\
\hline Bias & Authors' judgement & Support for judgement \\
\hline $\begin{array}{l}\text { Random sequence generation (selection } \\
\text { bias) }\end{array}$ & Low risk & Randomly assigned by the flip of a coin. \\
\hline Allocation concealment (selection bias) & Low risk & Randomly assigned by the flip of a coin. \\
\hline $\begin{array}{l}\text { Blinding (performance bias and detection } \\
\text { bias) } \\
\text { Patients and providers }\end{array}$ & High risk & No blinding. \\
\hline $\begin{array}{l}\text { Blinding (performance bias and detection } \\
\text { bias) } \\
\text { Assessors }\end{array}$ & Unclear risk & It is not stated whether assessors were blinded. \\
\hline $\begin{array}{l}\text { Incomplete outcome data (attrition bias) } \\
\text { All outcomes }\end{array}$ & Low risk & $\begin{array}{l}5 \% \text { lost to follow-up. Reasons not stated. Balanced. ITT not } \\
\text { conducted. }\end{array}$ \\
\hline Selective reporting (reporting bias) & Low risk & $\begin{array}{l}\text { The published report included all expected outcomes based on } \\
\text { the study hypotheses. }\end{array}$ \\
\hline Other bias & High risk & $\begin{array}{l}\text { Only self-report but included the Social Desirability Scale. Par- } \\
\text { ticipants in the BMI group were in an earlier college year and } \\
\text { had higher RAPI scores than participants in the written feedback } \\
\text { group at baseline. }\end{array}$ \\
\hline
\end{tabular}


Winhusen 2008

\begin{tabular}{ll}
\hline Methods & Multisite RCT (4 sites). \\
\hline Participants & 200 US pregnant substance users. \\
\hline Interventions & 3 session MET ( $\mathrm{n}=102)$ vs treatment as usual $(\mathrm{n}=98)$. \\
\hline Outcomes & $\begin{array}{l}\text { Physiological primary: Urine toxicology } \\
\text { Non-physiological primary: Days of use alcohol/drugs. } \\
\text { Secondary: Readiness to change (URICA). }\end{array}$ \\
\hline Notes & \\
\hline
\end{tabular}

\section{Risk of bias}

\begin{tabular}{|c|c|c|}
\hline Bias & Authors' judgement & Support for judgement \\
\hline $\begin{array}{l}\text { Random sequence generation (selection } \\
\text { bias) }\end{array}$ & Low risk & Used urn randomisation. \\
\hline Allocation concealment (selection bias) & Unclear risk & Insufficient information to permit judgment. \\
\hline $\begin{array}{l}\text { Blinding (performance bias and detection } \\
\text { bias) } \\
\text { Patients and providers }\end{array}$ & Low risk & $\begin{array}{l}\text { No blinding, but most outcomes were physiological and also } \\
\text { used to validate self-reports, and not likely to be influenced } \\
\text { by lack of blinding. }\end{array}$ \\
\hline $\begin{array}{l}\text { Blinding (performance bias and detection } \\
\text { bias) } \\
\text { Assessors }\end{array}$ & Low risk & $\begin{array}{l}\text { Insufficient information to know whether assessors were } \\
\text { blinded. But most outcomes were physiological and also used } \\
\text { to validate self-reports, and not likely to be influenced by lack } \\
\text { of blinding. }\end{array}$ \\
\hline $\begin{array}{l}\text { Incomplete outcome data (attrition bias) } \\
\text { All outcomes }\end{array}$ & Low risk & $\begin{array}{l}14 \% \text { attrition at } 1 \text { month follow-up and } 20 \% \text { attrition at } \\
3 \text { months. Balanced. Reasons for dropout stated. ITT was } \\
\text { performed. }\end{array}$ \\
\hline Selective reporting (reporting bias) & Low risk & $\begin{array}{l}\text { The published report included all expected outcomes based } \\
\text { on the study hypotheses. }\end{array}$ \\
\hline Other bias & Unclear risk & $\begin{array}{l}\text { Urine samples were collected and tested for opiates, co- } \\
\text { caine, methamphetamines, benzodiazepines, and marijuana } \\
\text { at screening, weekly during the active phase of the study } \\
\text { phase, and at the two follow-up visits. The MET group used } \\
\text { more cocaine and the TAU group used more marijuana at } \\
\text { baseline. There were also baseline differences in age, ethnic- } \\
\text { ity, education and pressure to attend treatment. }\end{array}$ \\
\hline
\end{tabular}


Winters 2007

\begin{tabular}{|c|c|c|}
\hline Methods & \multicolumn{2}{|l|}{ RCT. } \\
\hline Participants & \multicolumn{2}{|c|}{ Students $(n=53)$ identified in a school setting as drug abusers. USA. } \\
\hline Interventions & \multicolumn{2}{|c|}{2 sessions of MI with the adolescent only $(\mathrm{n}=26)$ vs assessment only control $(\mathrm{n}=27)$. } \\
\hline Outcomes & \multicolumn{2}{|c|}{$\begin{array}{l}\text { Physiological primary: None. } \\
\text { Non-physiological primary: Number of alcohol use days, number of binge days, num } \\
\text { ber of illicit drug use days. } \\
\text { Secondary: Additional treatment. } \\
\text { Follow-up at } 6 \text { months. }\end{array}$} \\
\hline Notes & \multicolumn{2}{|c|}{$\begin{array}{l}\text { There was also a third group that received } 2 \text { sessions with the adolescent and one with the } \\
\text { parent }(n=26) \text {. This group did not meet our inclusion criteria. } 1 \text { student in the control } \\
\text { group dropped out, so each group in the analyses contain } 26 \text { students. }\end{array}$} \\
\hline \multicolumn{3}{|l|}{ Risk of bias } \\
\hline Bias & Authors' judgement & Support for judgement \\
\hline $\begin{array}{l}\text { Random sequence generation (selection } \\
\text { bias) }\end{array}$ & Unclear risk & “...randomly assigned...” \\
\hline Allocation concealment (selection bias) & Unclear risk & Insufficient information to permit judgement. \\
\hline $\begin{array}{l}\text { Blinding (performance bias and detection } \\
\text { bias) } \\
\text { Patients and providers }\end{array}$ & High risk & No blinding. \\
\hline $\begin{array}{l}\text { Blinding (performance bias and detection } \\
\text { bias) } \\
\text { Assessors }\end{array}$ & Low risk & $\begin{array}{l}\text { "An experienced research assistant, who was blind to treatment } \\
\text { condition, completed the intake, 1-month, and 6-months fol- } \\
\text { low-up interviews." }\end{array}$ \\
\hline $\begin{array}{l}\text { Incomplete outcome data (attrition bias) } \\
\text { All outcomes }\end{array}$ & Low risk & $1 \%$ attrition at 6 months follow-up. \\
\hline Selective reporting (reporting bias) & Low risk & $\begin{array}{l}\text { The published report included all expected outcomes based on } \\
\text { the study hypotheses. }\end{array}$ \\
\hline Other bias & High risk & $\begin{array}{l}\text { "During the } 6 \text {-months TSR interview, those in the BI-AP condi- } \\
\text { tion reported more additional treatment (27\%) compared with } \\
\text { those in the BI-A condition (16\%)". Only self-report. There } \\
\text { were no differences between groups at baseline. }\end{array}$ \\
\hline
\end{tabular}


Wood 2007

\begin{tabular}{ll}
\hline Methods & RCT (2x2 factorial design). \\
\hline Participants & 335 US heavy drinking college students. \\
\hline Interventions & $\begin{array}{l}\text { 1. Brief MI (BMI) }(\mathrm{n}=84) \\
\text { 2. Alcohol Expectancy Challenge (AEC) }(\mathrm{n}=87) \\
\text { 3. BMI and AEC }(\mathrm{n}=81) \\
\text { assessment only }(\mathrm{n}=83) . \\
\text { AEC involved } 2 \text { sessions with a group discussion about alcohol expectancies in a simulated } \\
\text { bar environment. }\end{array}$ \\
\hline Outcomes & $\begin{array}{l}\text { Physiological primary: None. } \\
\text { Non-physiological primary: Number of drinks per week, number of heavy drinking } \\
\text { episodes in the past } 30 \text { days. Hangovers, blackouts, increased subjective tolerance. } \\
\text { Secondary: None. }\end{array}$ \\
\hline Notes & \\
\hline
\end{tabular}

\section{Risk of bias}

\begin{tabular}{|c|c|c|}
\hline Bias & Authors' judgement & Support for judgement \\
\hline $\begin{array}{l}\text { Random sequence generation (selection } \\
\text { bias) }\end{array}$ & Unclear risk & "...randomized, separately by gender." \\
\hline Allocation concealment (selection bias) & Unclear risk & Insufficient information to permit judgment. \\
\hline $\begin{array}{l}\text { Blinding (performance bias and detection } \\
\text { bias) } \\
\text { Patients and providers }\end{array}$ & High risk & No blinding. \\
\hline $\begin{array}{l}\text { Blinding (performance bias and detection } \\
\text { bias) } \\
\text { Assessors }\end{array}$ & Unclear risk & It is not stated whether the assessors were blinded. \\
\hline $\begin{array}{l}\text { Incomplete outcome data (attrition bias) } \\
\text { All outcomes }\end{array}$ & High risk & $\begin{array}{l}\text { "Cumulative participant attrition was } 18 \%, 25 \% \text {, and } \\
28 \% \text { at } 1-, 3-\text {, and } 6 \text { month follow-ups, respectively. Not } \\
\text { balanced. } 21 \text { in the AEC group and } 24 \text { in the BMI-AEC } \\
\text { group were dropped by design because it was not possi- } \\
\text { ble to schedule them for at least one of two group AEC } \\
\text { sessions. ITT was not performed. }\end{array}$ \\
\hline Selective reporting (reporting bias) & Low risk & $\begin{array}{l}\text { The published report included all expected outcomes } \\
\text { based on the study hypotheses. }\end{array}$ \\
\hline Other bias & Unclear risk & $\begin{array}{l}\text { Only self-reported outcomes. There were no differences } \\
\text { between groups at baseline. }\end{array}$ \\
\hline
\end{tabular}


Characteristics of excluded studies [ordered by study ID]

\begin{tabular}{|c|c|}
\hline Study & Reason for exclusion \\
\hline Adamson 2001 & Substance abuse was not an outcome. \\
\hline Allsop 1997 & Group MI. \\
\hline Anderson 1992 & Intervention was not MI. \\
\hline Aubrey 1998 & Not fidelity check using video or audio. \\
\hline Baer 2001 & Not fidelity check using video or audio. \\
\hline Baker 1993 & Substance abuse was not an outcome. \\
\hline Baker 2001 & Not fidelity check using video or audio. \\
\hline Baker 2002 & Not fidelity check using video or audio. \\
\hline Baker 2002b & Substance abuse was not an outcome. \\
\hline Baker 2005 & Not fidelity check using video or audio. \\
\hline Baker 2006 & Not fidelity check using video or audio. \\
\hline Barrowclough 2000 & No results reported. Ongoing study in 2000. \\
\hline Barrowclough 2001 & Not individual face-to-face intervention. \\
\hline Becka 2004 & Not a randomized controlled trial. \\
\hline Beckham 2007 & Not fidelity check using video or audio. \\
\hline Bellack 2006 & Intervention was not MI. \\
\hline Bernstein 2005 & Not fidelity check using video or audio. \\
\hline Bethea 2006 & Intervention was not MI. \\
\hline Booth 1998 & Substance abuse was not an outcome. \\
\hline Borsari 2000 & Not fidelity check using video or audio. \\
\hline Borsari 2003 & Intervention was not MI. \\
\hline Brown 1993 & Not a randomized controlled trial. \\
\hline Brown 2007 & Not individual face-to-face intervention. (Telephone and mail intervention). \\
\hline
\end{tabular}


(Continued)

\begin{tabular}{|c|c|}
\hline Brown 2009 & Not fidelity check using video or audio. \\
\hline Butler 2009 & Not fidelity check using video or audio. \\
\hline Bux 2005 & Intervention was not MI. \\
\hline Ceperich 2002 & No data reported. \\
\hline Chapman 2009 & Not individual face-to-face intervention. \\
\hline Chavez 2003 & Substance abuse was not an outcome. \\
\hline Clinton-Sherrod 2008 & Substance abuse was not an outcome. \\
\hline Corrigan 2005 & Substance use was not an outcome. \\
\hline D’Angelo 2005 & Not fidelity check using video or audio. \\
\hline Daeppen 2007 & Not MI \\
\hline Daley 1998 & Substance use was not an outcome. \\
\hline Davidson 2007 & Did not compare MI with alternative. Both conditions received MI. \\
\hline Davis 2003 & Not fidelity check using video or audio. \\
\hline Demmel 2003 & Not a randomized controlled trial. \\
\hline Dench 2000 & Substance abuse was not an outcome. \\
\hline Dent 2008 & Not fidelity check using video or audio. Main references to Miller and Rollnick are missing. \\
\hline Dermen 2000 & Not MI \\
\hline Disney 2005 & Substance abuse was not an outcome. \\
\hline Dunn 1997 & Not a randomised controlled trial. \\
\hline Dunn 2004 & Substance abuse was not an outcome. \\
\hline Easton 2000 & Substance abuse was not an outcome. \\
\hline Edwards 2006 & Not fidelity check using video or audio. \\
\hline Fergusin 1998 & Not MI. \\
\hline
\end{tabular}

Floyd $2007 \quad$ Not fidelity check using video or audio. 
(Continued)

\begin{tabular}{|c|c|}
\hline Gauthier-Faille 2006 & Not MI. \\
\hline Gentilello 2001 & Substance abuse was not an outcome (outcomes were injuries and traumas.) \\
\hline Ginsburg 2001 & Substance abuse was not an outcome. \\
\hline Godley 2010 & Not individual face-to-face intervention. (Part of the intervention involved the family.) \\
\hline Gogineni 2005 & Not MI. \\
\hline Goti 2010 & Not fidelity check using video or audio. \\
\hline Gray 2005 & Not a randomized controlled trial. \\
\hline Gregory 2001 & Not MI. Not substance abusers. \\
\hline Gwadz 2008 & Not MI. \\
\hline Handmaker 1999 & Not substance abusers. \\
\hline Harper 2000 & Not a randomized controlled trial. \\
\hline Haug 2004 & Substance abuse was not an outcome. \\
\hline Hayes 2007 & Not substance abusers. \\
\hline Heather 1996 & Not a randomized controlled trial. \\
\hline Hester 2005 & Not individual face-to-face intervention. \\
\hline Hickman 1999 & Not fidelity check using video or audio. \\
\hline Hicks 1999 & Not fidelity check using video or audio. \\
\hline Holder 2000 & Not a randomized controlled trial. \\
\hline Hulse 2003 & Substance abuse was not an outcome. \\
\hline Johnson 2006 & Intervention was not MI. \\
\hline Juarez 2006 & Not substance abusers. \\
\hline Jungerman 2007 & Not fidelity check using video or audio. \\
\hline Kanouse 2005 & Not a randomized controlled trial. \\
\hline Kidorf 2005 & Substance abuse was not an outcome. \\
\hline
\end{tabular}


(Continued)

\begin{tabular}{|c|c|}
\hline Kidorf 2009 & Not fidelity check using video or audio. \\
\hline Kinlock 2005 & Substance abuse was not an outcome. \\
\hline Kuchipudi 1990 & Not fidelity check using video or audio. \\
\hline Lachance 2004 & Not MI. \\
\hline Larimer 2001 & Not substance abusers. \\
\hline Longabaugh 2001 & Not substance abusers. \\
\hline Longabaugh 2009 & Not fidelity check using video or audio. \\
\hline Lozano 2006 & Intervention was not MI. \\
\hline Magill 2009 & Not fidelity check using video or audio. \\
\hline Mahmood 2002 & Substance abuse was not an outcome. \\
\hline Marlatt 1998 & Not fidelity check using video or audio. \\
\hline Martino 2000 & Not fidelity check using video or audio. \\
\hline Mausbach 2007 & Substance abuse was not an outcome. \\
\hline McCambridge 2004 & Not fidelity check using video or audio. \\
\hline McDowell 2006 & Intervention was not MI. \\
\hline Mckee 2007 & Not fidelity check using video or audio. \\
\hline McNally 2005 & Not fidelity check using video or audio. \\
\hline Michael 2006 & Not individual face-to-face intervention. \\
\hline Miller 2005 & Not a randomized controlled trial. \\
\hline Mitcheson 2007 & Not MI. \\
\hline Monti 1999 & Not substance abusers. \\
\hline Monti 2007 & Not substance abusers. \\
\hline Morgenstern 2007 & Did not compare MI with alternative intervention. \\
\hline Mullins 2004 & Sub \\
\hline
\end{tabular}


(Continued)

\begin{tabular}{|c|c|}
\hline Murphy 2001 & Does not compare MI with alternative intervention. \\
\hline Murphy 2003 & Not MI. \\
\hline Murphy 2004 & Not fidelity check using video or audio. \\
\hline Noonan 2001 & Not individual face-to-face intervention (Group MI.) \\
\hline Oliveira 2008 & Not fidelity check using video or audio. \\
\hline Ondersma 2007 & Not individual face-to-face intervention. (Computer-delivered.) \\
\hline Parsons 2007 & Not fidelity check using video or audio. \\
\hline Patterson 2008 & Not a randomized controlled trial. \\
\hline Pavone 2002 & Not a randomized controlled trial. \\
\hline Rao 1999 & Not individual face-to-face intervention. \\
\hline Reid 2005 & Not MI. \\
\hline Rimmele 1998 & Not a randomized controlled trial. \\
\hline Samet 2005 & Substance abuse was not an outcome. \\
\hline Sanchez 2001 & Not MI. \\
\hline Sanchez-Craig 1996 & Not fidelity check using video or audio. \\
\hline Santa Ana 2005 & Not MI. \\
\hline Santa Ana 2007 & Not individual face-to-face intervention. (Group MI.) \\
\hline Saunders 1995 & Not fidelity check using video or audio. \\
\hline Schilling 2002 & Not a randomized controlled trial. \\
\hline Scott 2002 & Substance abuse was not an outcome. \\
\hline Scott 2009 & Not MI. \\
\hline Sears 2006 & Substance abuse was not an outcome. \\
\hline Sinha 2003 & Not fidelity check using video or audio. \\
\hline Sitharthan 1999 & randomized controlled trial. \\
\hline
\end{tabular}


(Continued)

\begin{tabular}{|c|c|}
\hline Sobell 2002 & Not individual face to face intervention. \\
\hline Soderstrom 2007 & Not substance abusers. \\
\hline Stein $2002 a$ & Not a randomized controlled trial. \\
\hline Stein 2006 & Substance abuse was not an outcome. \\
\hline Stein $2006 a$ & Substance abuse was not an outcome. \\
\hline Stephens 2000 & Not fidelity check using video or audio. \\
\hline Stephens 2002 & Not a randomized controlled trial. \\
\hline Stockwell 1986 & Not a randomized controlled trial. \\
\hline Stotts 2004 & Not MI. \\
\hline Swanson 1999 & Substance abuse was not an outcome. \\
\hline Tapert 2003 & Not substance abusers. \\
\hline Tevyaw 2007 & Not individual face-to-face intervention. \\
\hline Thevos 1998 & Not a randomized controlled trial. \\
\hline Thush 2007 & Not fidelity check using video or audio. \\
\hline Tirado 2005 & Not MI. \\
\hline Vanderburg 2003 & Substance abuse was not an outcome. \\
\hline Velasquez 2009 & Not individual face-to-face intervention. (Both individual and group MI.) \\
\hline Wain 2006 & Substance abuse was not an outcome. \\
\hline Walters 2000 & Intervention was not MI. \\
\hline Walton 2010 & Intervention is opportunistic one-session MI in emergeny room. \\
\hline Weinrieb 2005 & Not MI. \\
\hline Wells 1998 & Not a randomized controlled trial. \\
\hline Wells 2004 & Not MI. \\
\hline Wertz 1994 & Not fidelity check using video or audio. \\
\hline Whitten 2006 & Substance abuse was not an outcome. \\
\hline
\end{tabular}


(Continued)

\begin{tabular}{ll}
\hline Wilbourne 2005 & Not a randomized controlled trial. \\
\hline Woodall 2007 & Not fidelity check using video or audio. \\
\hline Woody 2001 & Not MI. \\
\hline Yonkers 2009 & Not a randomized controlled trial. \\
\hline Zahradnik 2009 & Not acceptable drug (prescription drugs). \\
\hline Zule 2009 & Not fidelity check using video or audio. \\
\hline
\end{tabular}

\section{Characteristics of studies awaiting assessment [ordered by study ID]}

\section{Barrowclough 2010}

\begin{tabular}{ll}
\hline Methods & RCT. \\
\hline Participants & Patients with psychosis and substance abuse. \\
\hline Interventions & Integrated MI and CBT treatment vs standard psychiatric care. \\
\hline Outcomes & Frequency of substance abuse. \\
\hline Notes & \\
\hline
\end{tabular}

Walters 2010

\begin{tabular}{ll}
\hline Methods & Randomized effectiveness trial. \\
\hline Participants & 380 probationers. \\
\hline Interventions & MI vs waiting list control. \\
\hline Outcomes & Probability of having a drug-positive urinalysis or an otherwise poor outcome after 6 months. \\
\hline Notes & Study was located while preparing to submit the review. \\
\hline
\end{tabular}




\section{Characteristics of ongoing studies [ordered by study ID]}

\section{Dubertret 2010}

\begin{tabular}{ll} 
Trial name or title & Effect of motivational therapy on schizophrenia with cannabis misuse. \\
\hline Methods & RCT. \\
\hline Participants & Schizophrenia or schizo-affective disorder according to DSM-IV criteria. \\
\hline Interventions & MI vs usual care. \\
\hline Outcomes & $\begin{array}{l}\text { Cannabis consumption evaluated by the Time-Line Follow Back at } 6 \text { months inclusion, } 3 \text { month, } 6 \text { month, } \\
12 \text { month. }\end{array}$ \\
\hline Starting date & November 2008. \\
\hline Contact information & $\begin{array}{l}\text { Caroline Dubertret (caroline.dubertret@lmr.aphp.fr) } \\
\text { Assistance Publique - Hopitaux de Paris. } \\
\text { Telephone: }+33(0) 147606413\end{array}$ \\
\hline Notes & \\
\hline
\end{tabular}

Forsberg 2010

\begin{tabular}{ll}
\hline Trial name or title & Effects of Motivational Interviewing in Prison. \\
\hline Methods & RCT. \\
\hline Participants & Alcohol abusers. \\
\hline Interventions & MI vs usual planning interview routine. \\
\hline Outcomes & $\begin{array}{l}\text { Number of days with substance use of the last } 30 \text { days. Alcohol- or drug use as measured by the Addiction } \\
\text { Severity Index (ASI) at intake and at } 10 \text { months after release. }\end{array}$ \\
\hline Starting date & April 2004. \\
\hline Contact information & $\begin{array}{l}\text { Lars G Forsberg } \\
\text { Karolinska Institutet, Dep Clin. Neuroscience, Stockholm, Sweden. }\end{array}$ \\
\hline Notes & \\
\hline
\end{tabular}


Hansen 2010

\begin{tabular}{ll}
\hline Trial name or title & Brief intervention for heavy drinkers. \\
\hline Methods & RCT. \\
\hline Participants & Alcohol abusers. \\
\hline Interventions & MI vs leaflets about alcohol. \\
\hline Outcomes & Reduction of 25\% in self reported alcohol consumption. \\
\hline Starting date & January 2008. \\
\hline Contact information & $\begin{array}{l}\text { Anders B. Gottlieb Hansen } \\
\text { University of Southern Denmark, National Institute of Public Health. }\end{array}$ \\
\hline Notes & \\
\hline
\end{tabular}

\section{Morken 2010}

Trial name or title Motivational interviewing to acutely admitted psychiatric patients with comorbid substance use

\begin{tabular}{ll}
\hline Methods & Single-blind RCT. \\
\hline Participants & $\begin{array}{l}\text { Adult patients with substance use acutely admitted to psychiatric } \\
\text { hospital. }\end{array}$ \\
\hline Interventions & MI vs standard treatment. \\
\hline Outcomes & $\begin{array}{l}\text { Substance use and function questionnaire. } \\
\text { Admissions to hospital. } \\
\text { Number of contacts with primary health care. }\end{array}$ \\
\hline Starting date & October 2004. \\
\hline Contact information & $\begin{array}{l}\text { Gunnar Morken (gunnar.morken@ntnu.no) } \\
\text { Norwegian University of Science and Technology. }\end{array}$ \\
\hline Notes & \\
\hline
\end{tabular}


DATA AND ANALYSES

Comparison 1. MI versus no intervention

\begin{tabular}{lccll} 
Outcome or subgroup title & $\begin{array}{c}\text { No. of } \\
\text { studies }\end{array}$ & $\begin{array}{c}\text { No. of } \\
\text { participants }\end{array}$ & Statistical method & Effect size \\
\hline 1 Extent of substance use & 25 & & Std. Mean Difference (Random, 95\% CI) & Subtotals only \\
$\quad$ 1.1 Post-intervention & 4 & 202 & Std. Mean Difference (Random, 95\% CI) & $0.79[0.48,1.09]$ \\
1.2 Short f-u & 15 & 2327 & Std. Mean Difference (Random, 95\% CI) & $0.17[0.09,0.26]$ \\
1.3 Medium f-u & 12 & 2326 & Std. Mean Difference (Random, 95\% CI) & $0.15[0.04,0.25]$ \\
1 1.4 Long follow-up & 1 & 363 & Std. Mean Difference (Random, 95\% CI) & $0.06[-0.16,0.28]$ \\
2 Readiness to change & 5 & 1495 & Std. Mean Difference (Random, 95\% CI) & $0.05[-0.11,0.22]$ \\
3 Retention in treatment & 2 & 427 & Std. Mean Difference (Random, 95\% CI) & $0.26[-0.00,0.52]$ \\
\hline
\end{tabular}

Comparison 2. MI versus treatment as usual

\begin{tabular}{cccll} 
Outcome or subgroup title & $\begin{array}{c}\text { No. of } \\
\text { studies }\end{array}$ & $\begin{array}{c}\text { No. of } \\
\text { participants }\end{array}$ & Statistical method & Effect size \\
\hline 1 Extent of substance use & 11 & & Std. Mean Difference (Random, 95\% CI) & Subtotals only \\
1.1 Post-intervention & 9 & 1940 & Std. Mean Difference (Random, 95\% CI) & $0.01[-0.09,0.11]$ \\
1.2 Short f-u & 10 & 2102 & Std. Mean Difference (Random, 95\% CI) & $0.01[-0.08,0.10]$ \\
1.3 Medium f-u & 5 & 890 & Std. Mean Difference (Random, 95\% CI) & $0.08[-0.05,0.21]$ \\
2 Retention in treatment & 4 & 1354 & Std. Mean Difference (Random, 95\% CI) & $-0.11[-0.41,0.19]$ \\
\hline
\end{tabular}

Comparison 3. MI versus assessment and feedback

\begin{tabular}{ccccl} 
Outcome or subgroup title & $\begin{array}{c}\text { No. of } \\
\text { studies }\end{array}$ & $\begin{array}{c}\text { No. of } \\
\text { participants }\end{array}$ & Statistical method & Effect size \\
\hline 1 Extent of substance use & 7 & & Std. Mean Difference (Random, 95\% CI) & Subtotals only \\
1.1 Short f-u & 7 & 986 & Std. Mean Difference (Random, 95\% CI) & $0.12[-0.01,0.24]$ \\
1.2 Medium f-u & 2 & 265 & Std. Mean Difference (Random, 95\% CI) & $0.38[0.10,0.66]$ \\
\hline
\end{tabular}


Comparison 4. MI versus other active intervention

\begin{tabular}{lccll} 
Outcome or subgroup title & $\begin{array}{c}\text { No. of } \\
\text { studies }\end{array}$ & $\begin{array}{c}\text { No. of } \\
\text { participants }\end{array}$ & Statistical method & Effect size \\
\hline 1 Extent of substance use & 14 & & Std. Mean Difference (Random, 95\% CI) & Subtotals only \\
$\quad 1.1$ Post-intervention & 2 & 185 & Std. Mean Difference (Random, 95\% CI) & $-0.07[-0.37,0.23]$ \\
1.2 Short f-u & 12 & 2137 & Std. Mean Difference (Random, 95\% CI) & $0.02[-0.07,0.12]$ \\
1.3 Medium f-u & 6 & 1586 & Std. Mean Difference (Random, 95\% CI) & $-0.02[-0.16,0.13]$ \\
1.4 Long f-u & 2 & 437 & Std. Mean Difference (Random, 95\% CI) & $-0.03[-0.21,0.14]$ \\
2 Readiness to change & 2 & 350 & Std. Mean Difference (Random, 95\% CI) & $-0.03[-0.24,0.18]$ \\
3 Retention in treatment & 5 & 447 & Std. Mean Difference (Random, 95\% CI) & $0.01[-0.45,0.47]$ \\
\hline
\end{tabular}

\section{Analysis I.I. Comparison I MI versus no intervention, Outcome I Extent of substance use.}

Review: Motivational interviewing for substance abuse

Comparison: I MI versus no intervention

Outcome: I Extent of substance use

\begin{tabular}{|c|c|c|c|c|c|c|c|}
\hline \multirow{2}{*}{$\begin{array}{r}\text { Study or subgroup } \\
\text { I Post-intervention }\end{array}$} & $\begin{array}{r}\text { Control } \\
\mathrm{N}\end{array}$ & $\begin{array}{l}\mathrm{MI} \\
\mathrm{N}\end{array}$ & Std. Mean Difference (SE) & \multicolumn{2}{|c|}{$\begin{array}{l}\text { Std. Mean Difference } \\
\text { IV,Random,95\% Cl }\end{array}$} & Weight & $\begin{array}{r}\text { Std. Mean Difference } \\
\text { IV,Random,95\% Cl }\end{array}$ \\
\hline & & & & & & & \\
\hline Ball 2007a & 29 & 34 & $0.47(0.26)$ & & 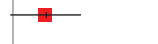 & $34.7 \%$ & $0.47[-0.04,0.98]$ \\
\hline Connors 2002 & 36 & 40 & $0.878(0.241)$ & & $\because$ & $40.2 \%$ & $0.88[0.41,1.35]$ \\
\hline Kelly 2000 & 16 & 16 & $1.245(0.386)$ & & $\longrightarrow$ & $15.9 \%$ & $1.25[0.49,2.00]$ \\
\hline Stotts 2006 & 14 & 17 & $0.801(0.507)$ & & ? & $9.2 \%$ & $0.80[-0.19,1.79]$ \\
\hline \multicolumn{5}{|c|}{ Subtotal $(95 \% \mathrm{CI})$} & $<$ & $100.0 \%$ & $0.79[0.48,1.09]$ \\
\hline \multicolumn{8}{|c|}{ Heterogeneity: $\operatorname{Tau}^{2}=0.00 ; \mathrm{Chi}^{2}=3.04, \mathrm{df}=3(\mathrm{P}=0.39) ; \mathrm{I}^{2}=1 \%$} \\
\hline \multicolumn{8}{|c|}{ Test for overall effect: $Z=5.10(P<0.0000 I)$} \\
\hline \multicolumn{8}{|l|}{2 Short f-u } \\
\hline Bell 2007 & 20 & 40 & $-0.028(0.346)$ & & 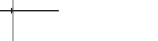 & $1.4 \%$ & $-0.03[-0.71,0.65]$ \\
\hline Carey 2006 & 81 & 81 & $0.19(0.111)$ & & 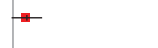 & $9.8 \%$ & $0.19[-0.03,0.41]$ \\
\hline Carroll 2006a & 178 & 173 & $0.097(0.076)$ & & \# & $15.4 \%$ & $0.10[-0.05,0.25]$ \\
\hline Feldstein 2007 & 15 & 40 & $0.345(0.305)$ & & + & $1.8 \%$ & $0.35[-0.25,0.94]$ \\
\hline Kay-Lambkin 2009 & 30 & 35 & $-0.048(0.25)$ & & 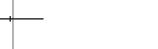 & $2.6 \%$ & $-0.05[-0.54,0.44]$ \\
\hline Kelly 2000 & 16 & 16 & $1.23(0.386)$ & & 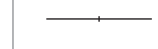 & $1.2 \%$ & $1.23[0.47,1.99]$ \\
\hline \multirow[t]{3}{*}{ MarijuanaTP 2004} & 148 & 146 & $0.32(0.1 \mid 8)$ & & $\rightarrow$ & $9.0 \%$ & $0.32[0.09,0.55]$ \\
\hline & & & & -1 & 0 & & \\
\hline & & & & Favours control & Favours Ml & & \\
\hline
\end{tabular}




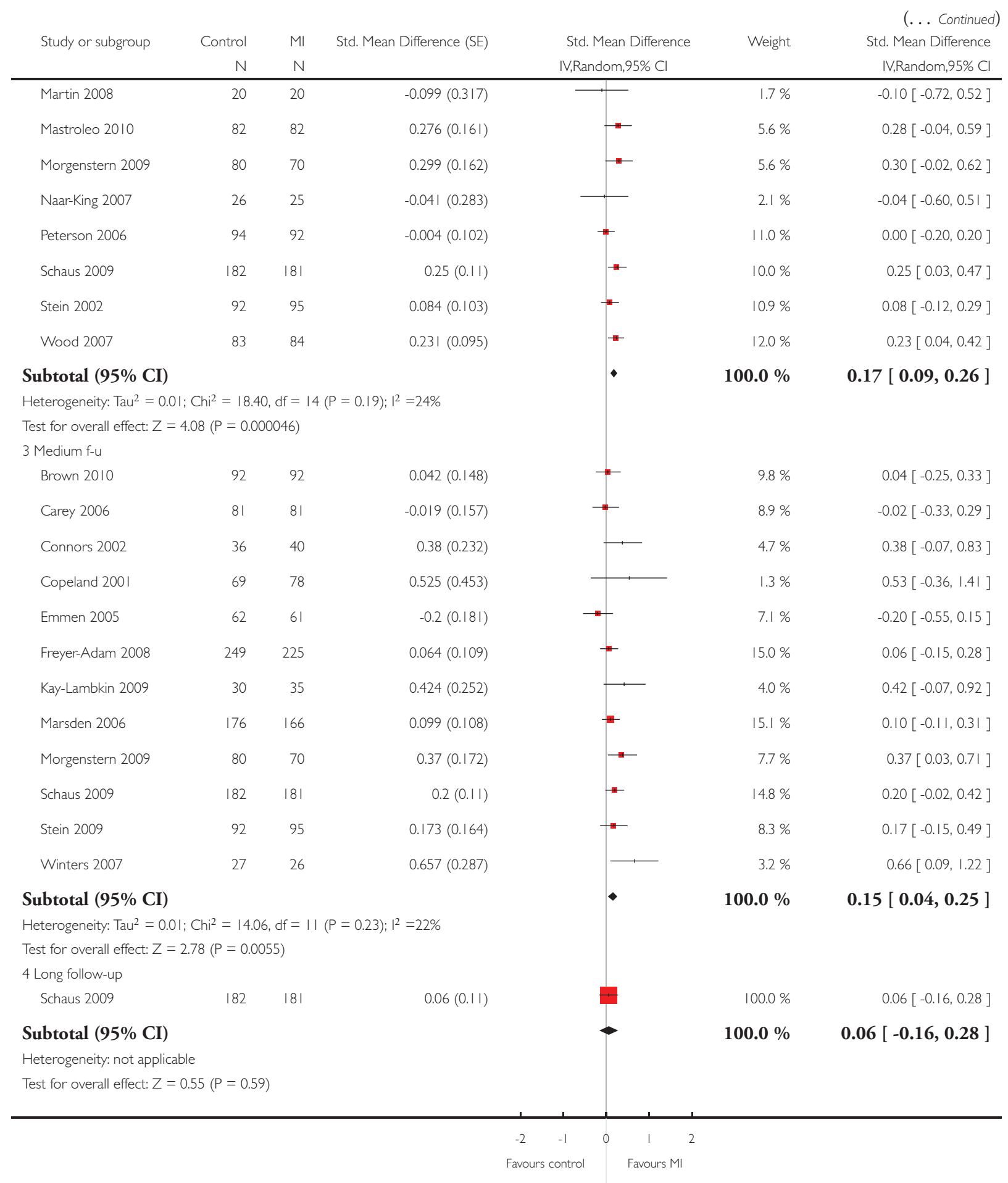

Motivational interviewing for substance abuse (Review) 


\section{Analysis I.2. Comparison I MI versus no intervention, Outcome 2 Readiness to change.}

Review: Motivational interviewing for substance abuse

Comparison: I Ml versus no intervention

Outcome: 2 Readiness to change

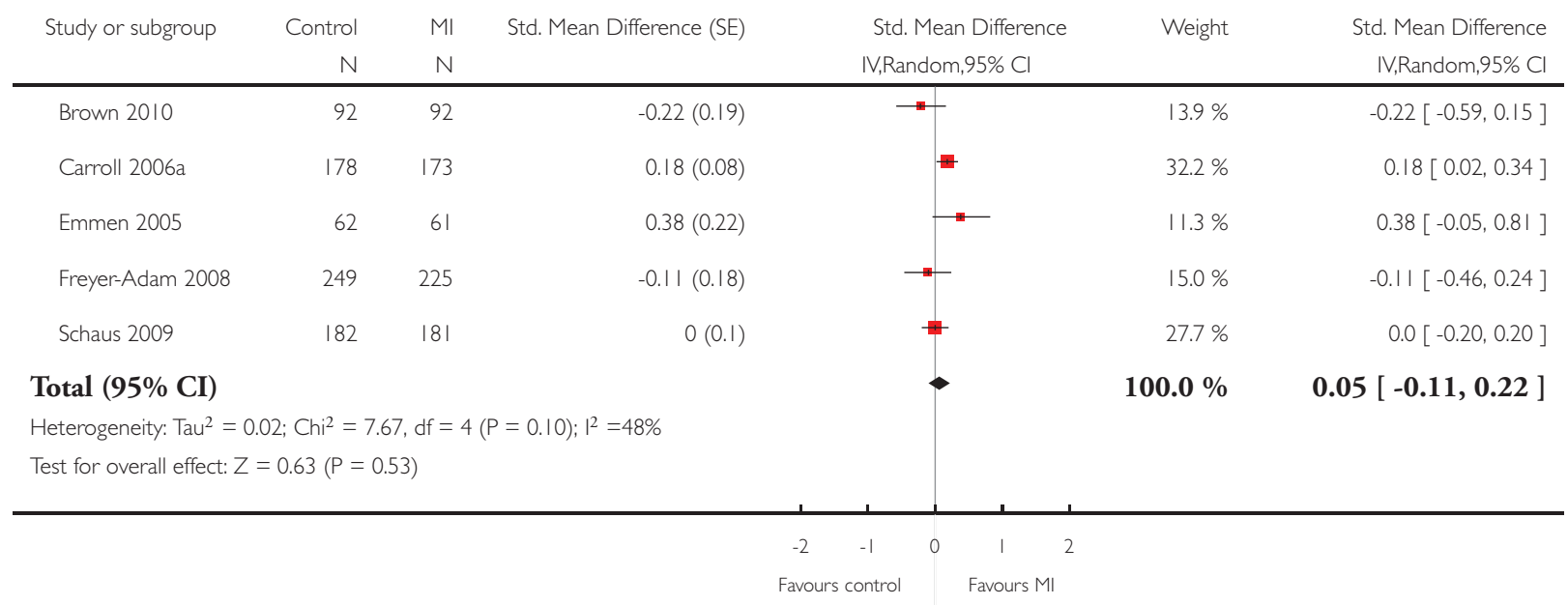

\section{Analysis I.3. Comparison I MI versus no intervention, Outcome 3 Retention in treatment.}

Review: Motivational interviewing for substance abuse

Comparison: I Ml versus no intervention

Outcome: 3 Retention in treatment

\begin{tabular}{|c|c|c|c|c|c|c|}
\hline \multirow[t]{2}{*}{ Study or subgroup } & Control & MI & Std. Mean Difference (SE) & Std. Mean Difference & Weight & Std. Mean Difference \\
\hline & $\mathrm{N}$ & $\mathrm{N}$ & & IV,Random,95\% Cl & & IV,Random,95\% Cl \\
\hline Carroll 2006a & 178 & 173 & $0.18(0.08)$ & + & $75.2 \%$ & $0.18[0.02,0.34]$ \\
\hline Connors 2002 & 36 & 40 & $0.488(0.233)$ & - & $24.8 \%$ & $0.49[0.03,0.94]$ \\
\hline
\end{tabular}

Total (95\% CI)

$100.0 \%$

Heterogeneity: $\mathrm{Tau}^{2}=0.02 ; \mathrm{Ch}^{2}=1.56, \mathrm{df}=\mathrm{I}(\mathrm{P}=0.2 \mathrm{I}) ; \mathrm{I}^{2}=36 \%$

Test for overall effect: $Z=1.93(P=0.054)$

$\begin{array}{ccccc}-2 & -1 & 0 & 1 & 2 \\ \text { Favours control } & & \text { Favours Ml }\end{array}$


Analysis 2.I. Comparison 2 MI versus treatment as usual, Outcome I Extent of substance use.

Review: Motivational interviewing for substance abuse

Comparison: $2 \mathrm{Ml}$ versus treatment as usual

Outcome: I Extent of substance use

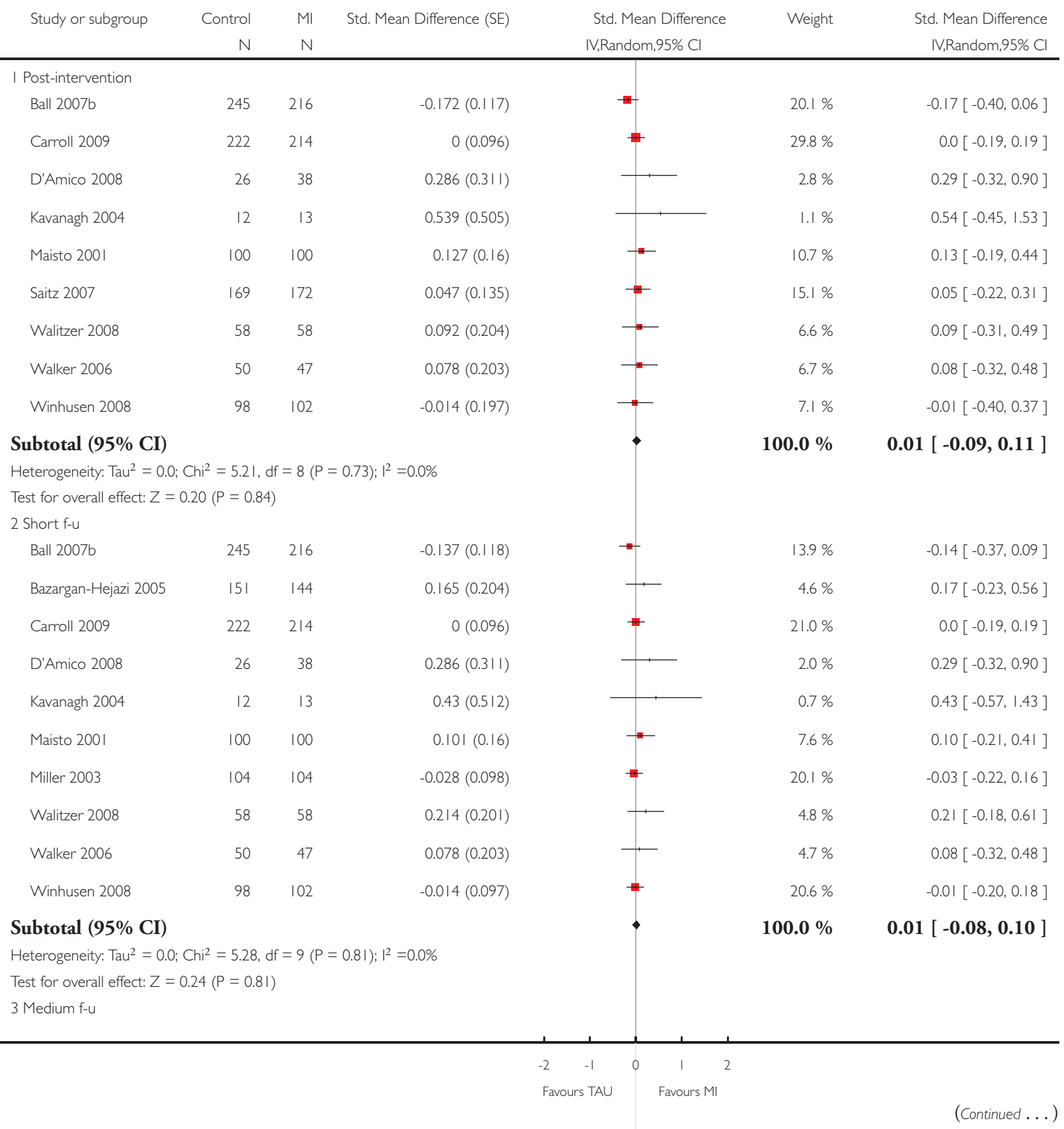

Motivational interviewing for substance abuse (Review) 


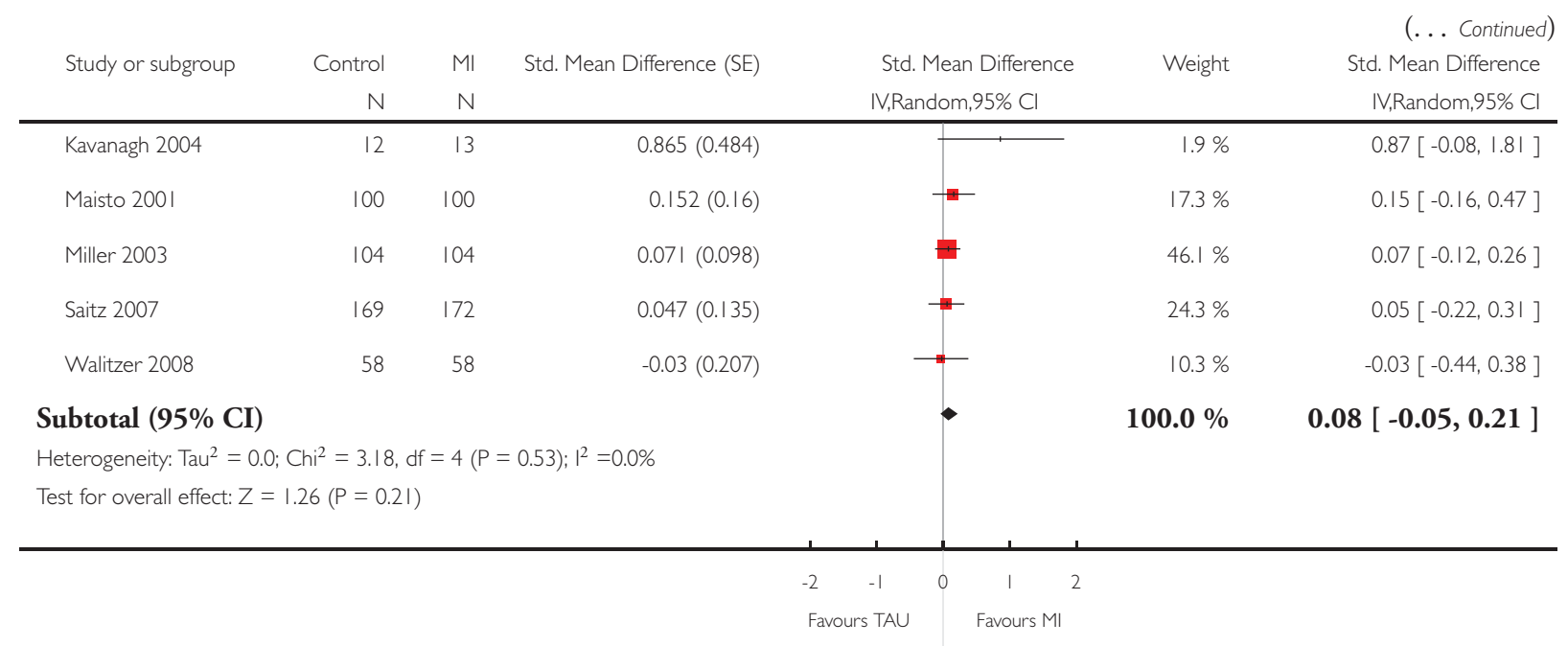

\section{Analysis 2.2. Comparison 2 MI versus treatment as usual, Outcome 2 Retention in treatment.}

Review: Motivational interviewing for substance abuse

Comparison: $2 \mathrm{Ml}$ versus treatment as usual

Outcome: 2 Retention in treatment

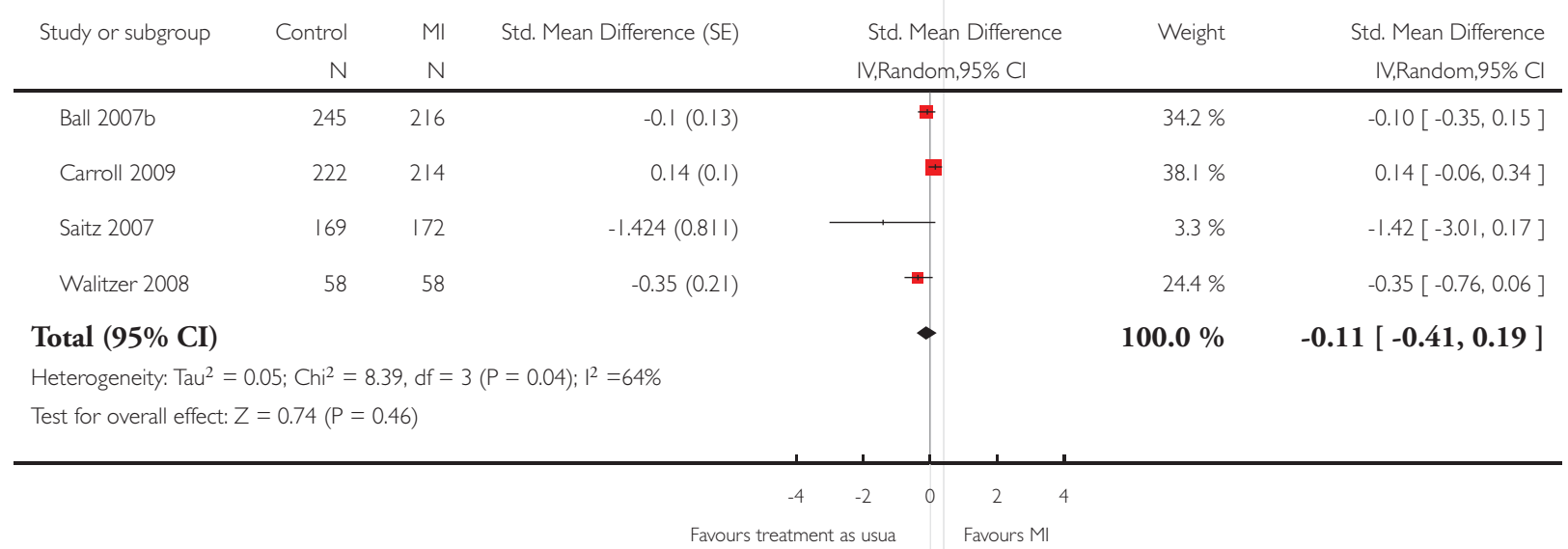


Analysis 3.I. Comparison $3 \mathrm{MI}$ versus assessment and feedback, Outcome I Extent of substance use. Review: Motivational interviewing for substance abuse

Comparison: $3 \mathrm{Ml}$ versus assessment and feedback

Outcome: I Extent of substance use

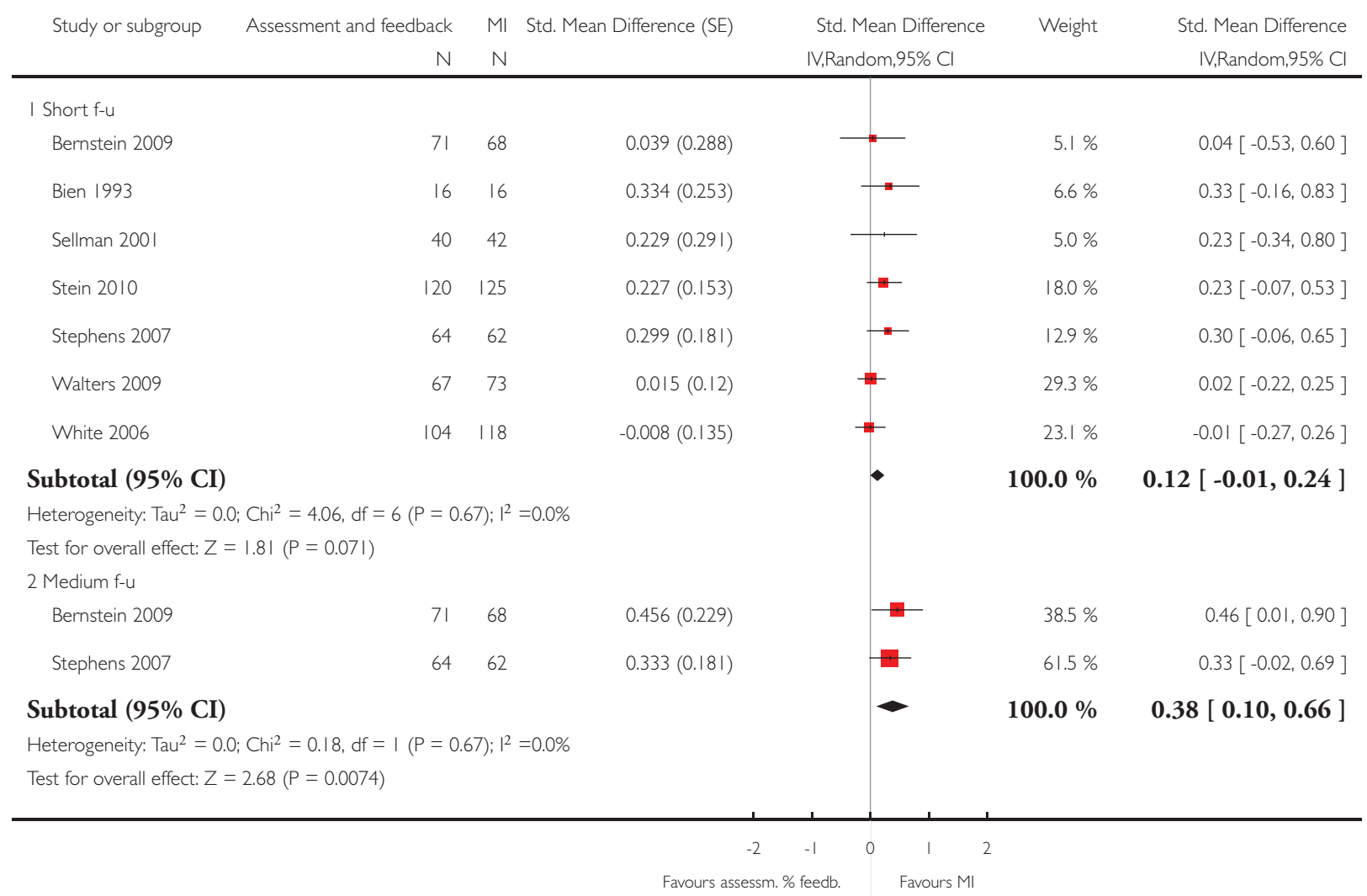


Analysis 4.I. Comparison $4 \mathrm{MI}$ versus other active intervention, Outcome I Extent of substance use. Review: Motivational interviewing for substance abuse

Comparison: $4 \mathrm{Ml}$ versus other active intervention

Outcome: I Extent of substance use

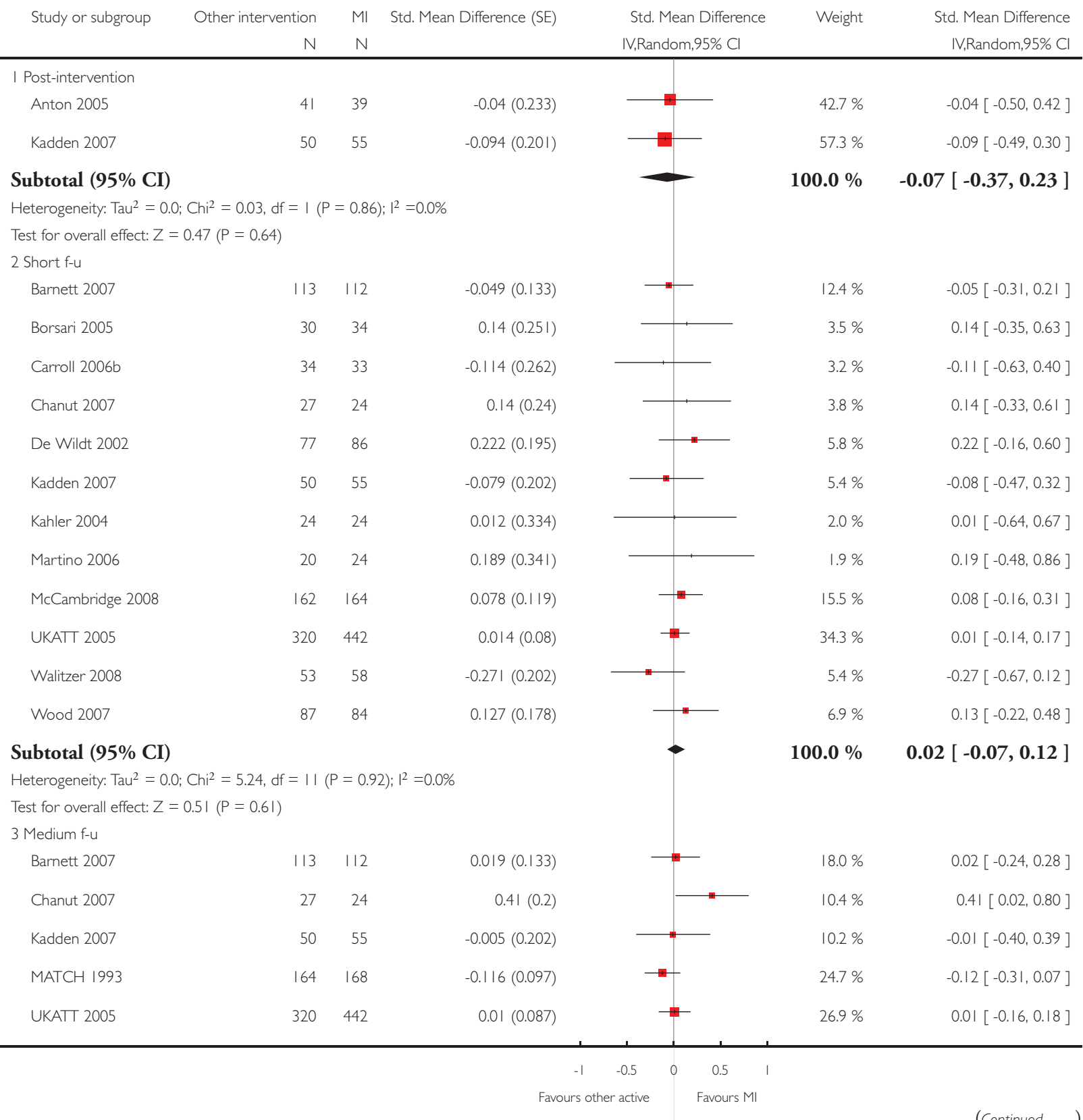

(Continued ...) 


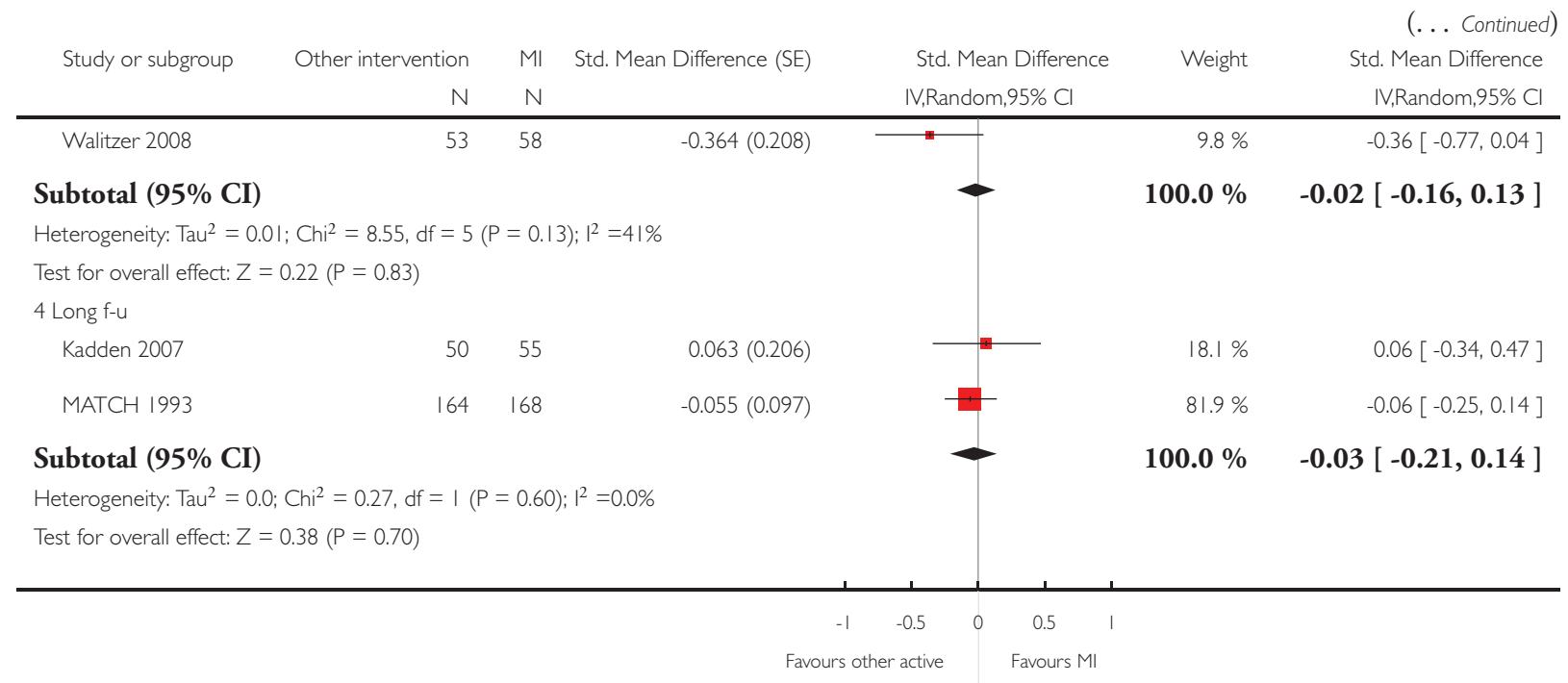

\section{Analysis 4.2. Comparison $4 \mathrm{MI}$ versus other active intervention, Outcome 2 Readiness to change.}

Review: Motivational interviewing for substance abuse

Comparison: $4 \mathrm{Ml}$ versus other active intervention

Outcome: 2 Readiness to change

\begin{tabular}{|c|c|c|c|c|c|c|}
\hline \multirow[t]{2}{*}{ Study or subgroup } & Other intervention & $\mathrm{Ml}$ & Std. Mean Difference (SE) & Std. Mean Difference & Weight & Std. Mean Difference \\
\hline & $\mathrm{N}$ & $\mathrm{N}$ & & IV,Random,95\% Cl & & IV,Random,95\% Cl \\
\hline Barnett 2007 & 113 & 112 & $-0.02(0.13)$ & 7 & $69.2 \%$ & $-0.02[-0.27,0.23]$ \\
\hline Kadden 2007 & 62 & 63 & $-0.051(0.195)$ & $\rightarrow$ & $30.8 \%$ & $-0.05[-0.43,0.33]$ \\
\hline \multicolumn{4}{|l|}{ Total (95\% CI) } & 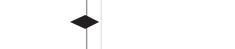 & $100.0 \%$ & $-0.03[-0.24,0.18]$ \\
\hline \multicolumn{7}{|c|}{ Heterogeneity: $\mathrm{Tau}^{2}=0.0 ; \mathrm{Chi}^{2}=0.02, \mathrm{df}=\mathrm{I}(\mathrm{P}=0.89) ; \mathrm{I}^{2}=0.0 \%$} \\
\hline \multicolumn{7}{|c|}{ Test for overall effect: $Z=0.27(P=0.78)$} \\
\hline
\end{tabular}

Favours other active Favours Ml 
Analysis 4.3. Comparison $4 \mathrm{MI}$ versus other active intervention, Outcome 3 Retention in treatment.

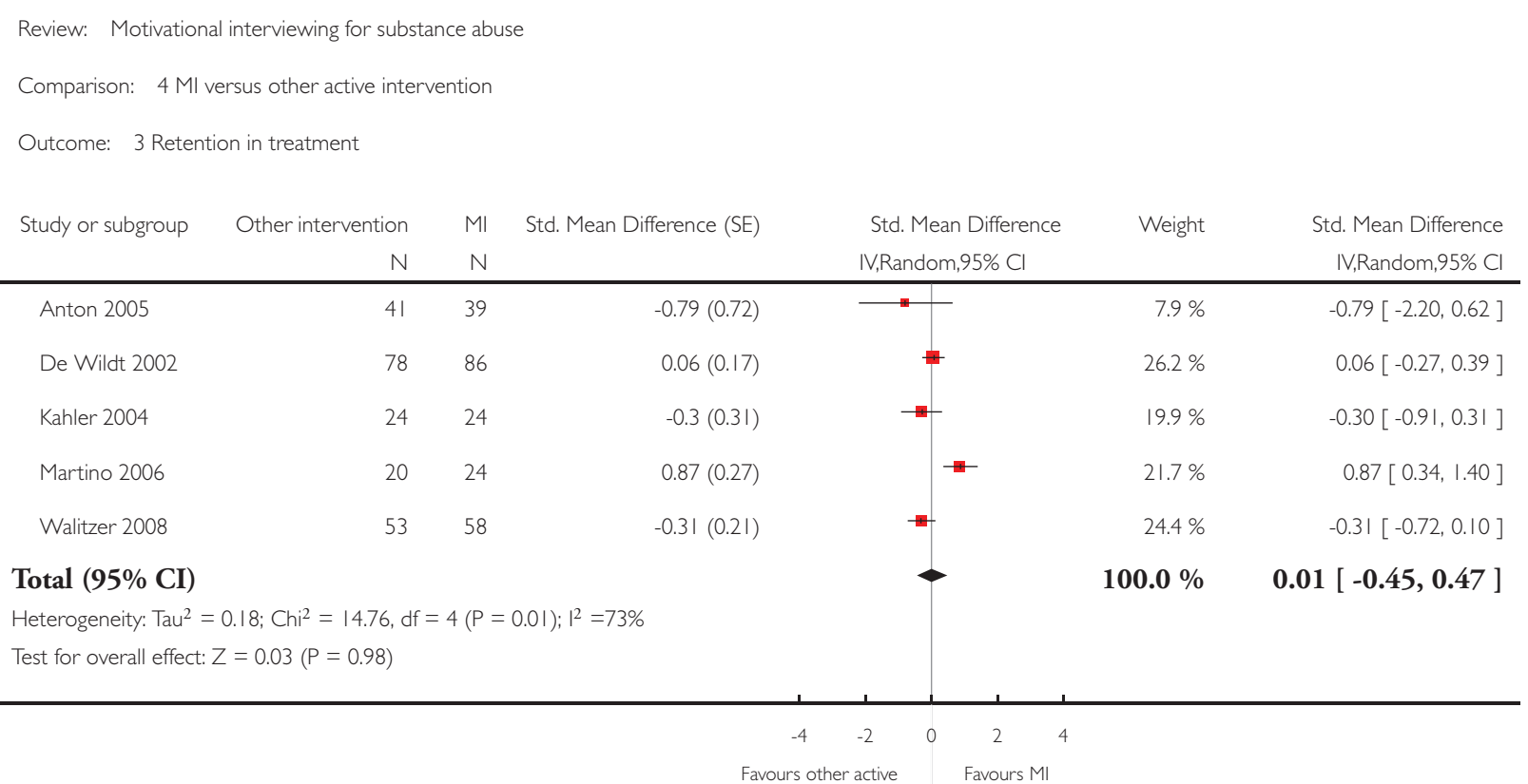

\section{A P PENDICES}

\section{Appendix I. Ovid MEDLINE}

1950 to November Week 32010

Date: 30.11.2010

1 Interview, Psychological/

2 Feedback, Psychological/

3 (interview\$ or feedback\$ or enhancement).tw.

4 or/ $1-3$

5 Motivation/

6 motivational\$.tw.

7 or $/ 5-6$

84 and 7

9 exp Substance-Related Disorders/

10 ((drug or substance $\$$ or alcohol or opioid $\$$ or amphetamine $\$$ or cocaine or marijuana or cannabis or phencyclidine or benzodiaz $\$$ )

adj2 (misuse or abuse $\$$ or addict $\$$ or depend\$)).tw.

11 (alcoholi\$ or drinker\$ or drinking\$).tw.

12 exp benzodiazepines/

13 or/9-12

148 and 13

15 clinical trial.pt.

16 randomized controlled trial.pt.

17 controlled clinical trial.pt. 
18 randomized.ti,ab.

19 placebo.ti,ab.

20 dt.fs.

21 randomly.ti,ab.

22 trial.ti,ab.

23 groups.ti,ab.

24 control\$.ti,ab.

25 quasi $\$$.ti,ab.

26 cluster\$.ti,ab.

27 or/ $15-26$

28 Animals/

29 Humans/

3028 not (28 and 29)

3127 not 30

3231 and 14

\section{Appendix 2. Ovid EMBASE}

1980 to 2010 Week 46

Date: 30.11 .2010

1. exp interview/

2. (interview\$ or feedback $\$$ or enhancement).tw.

3. or/1-2

4. motivation/

5. Motivational\$.tw.

6. or/4-5

7. Substance Abuse/

8. exp drug abuse/

9. exp Alcohol Abuse/

10. exp Drug Dependence/

11. Alcoholism/

12. Addiction/

13. Withdrawal Syndrome/

14. ((drug or substance $\$$ or alcohol or opioid $\$$ or amphetamine $\$$ or cocaine or marijuana or cannabis or phencyclidine or benzodiaz $\$$ )

adj2 (misuse or abuse $\$$ or addict $\$$ or depend $\$)$ ).tw.

15. (alcoholi\$ or drinker\$ or drinking\$).tw.

16. or/7-15

17.3 and 6 and 16

18. Clinical Trial/

19. Randomized Controlled Trial/

20. Randomization/

21. Double Blind Procedure/

22. Single Blind Procedure/

23. Crossover Procedure/

24. PLACEBO/

25. placebo\$.tw.

26. randomi?ed controlled trial\$.tw.

27. rct.tw.

28. random allocation.tw.

29. randomly allocated.tw.

30. allocated randomly.tw.

31. (allocated adj2 random).tw.

Motivational interviewing for substance abuse (Review)

Copyright $\odot$ 20II The Cochrane Collaboration. Published by John Wiley \& Sons, Ltd. 
32. single blind $\$$.tw.

33. double blind $\$$.tw.

34. ((treble or triple) adj blind\$).tw.

35. Prospective study/

36. or/18-35

37. Case study/

38. case report.tw.

39. Abstract report/

40. Letter/

41. Human/

42. Nonhuman/

43. ANIMAL/

44. Animal Experiment/

45.42 or 43 or 44

46. 45 not (41 and 45)

47. or/37- 40,46

48. 36 not 47

49. control\$.ti,ab.

50. quasi\$.ti,ab.

51. cluster\$.ti,ab.

52. or/49-51

53.36 or 52

54.53 not 47

55.54 and 17

\section{Appendix 3. Ovid PsycINFO}

Date: 30.11 .2010

1806 to November Week 42010

1 exp motivational interviewing/

2 (interview\$ or feedback\$ or enhancement\$).tw.

3 Motivational\$.tw.

42 and 3

51 or 4

6 exp drug abuse/

7 exp addiction/

8 ((drug or substance $\$$ or alcohol or opioid $\$$ or amphetamine $\$$ or cocaine or marijuana or cannabis or phencyclidine or benzodiaz\$)

adj2 (misuse or abuse $\$$ or addict $\$$ or depend $\$)$ ).tw.

9 (alcoholi\$ or drinker\$ or drinking\$).tw.

10 or/6-9

11 methodology/

12 data collection/

13 empirical methods/

14 Experimental methods/

15 Quasi experimental methods/

16 experimental design/

17 between groups design/

18 followup studies/

19 exp longitudinal studies/

20 repeated measures/

21 experimental subjects/

22 experiment controls/

Motivational interviewing for substance abuse (Review)

Copyright $(\underset{20}{ }$ II The Cochrane Collaboration. Published by John Wiley \& Sons, Ltd. 
23 experimental replication/

24 exp "sampling (experimental)"/

25 placebo/

26 clinical trials/

27 exp treatment outcomes/

28 treatment effectiveness evaluation/

29 empirical study.md.

30 experimental replication.md.

31 followup study.md.

32 longitudinal study.md.

33 meta analysis.md.

34 prospective study.md.

35 retrospective study.md.

36 treatment outcome clinical trial.md.

37 placebo\$.tw.

38 randomi?ed controlled trial\$.tw.

39 rct.tw.

40 random allocation.tw.

41 (randomly adj1 allocated).tw.

42 (allocated adj2 random).tw.

43 ((singl\$ or doubl $\$$ or treb\$ or tripl\$) adj (blind $\$ 3$ or mask $\$ 3)$ ).tw.

44 (clinic\$ adj (trial? or stud\$3)).tw.

45 or/11- 44

46 comment reply.dt.

47 editorial.dt.

48 letter.dt.

49 clinical case study.md.

50 nonclinical case study.md.

51 animal.po.

52 human.po.

5351 not (51 and 52)

54 or $/ 46-50,53$

5545 not 54

56 control\$.ti,ab.

57 quasi\$.ti,ab.

58 cluster\$.ti,ab.

59 or $/ 56-58$

6045 or 59

6160 not 54

625 and 10 and 61

\section{Appendix 4. Wiley; Cochrane Library}

Clinical Trials

Date: 30.11 .2010

\#1 MeSH descriptor Interview, Psychological explode all trees

\#2 MeSH descriptor Feedback, Psychological explode all trees

\#3 (interview* or feedback* or enhancement):ab,ti

\#4 (\#1 OR \#2 OR \#3)

\#5 MeSH descriptor Motivation explode all trees

\#6 motivational ${ }^{*}: \mathrm{ti}, \mathrm{ab}$

\#7 (\#5 OR \#6)

Motivational interviewing for substance abuse (Review)

Copyright (@) 201 I The Cochrane Collaboration. Published by John Wiley \& Sons, Ltd. 
\#8 (\#4 AND \#7)

\#9 MeSH descriptor Substance-Related Disorders explode all trees

\#10 MeSH descriptor Benzodiazepines explode all trees

\#11 ((drug or substance* or alcohol or opioid* or amphetamine* or cocaine or marijuana or cannabis or phencyclidine or benzodiaz*)

near/2 (misuse or abuse* or addict* or depend*)):ti,ab

\#12 (alcoholi* or drinker* or drinking*):ti,ab

\#13 (\#9 OR \#10 OR \#11 OR \#12)

\section{Appendix 5. Ovid PsychExtra}

1908 to January 14,2008

Date: 21.01 .2008

Note: RCT-filter not used

1 exp CRIMINALS/

2 exp CRIME/

3 exp Correctional Institutions/

4 exp PRISONERS/

5 (prison $\$$ or imprison\$ or offender $\$$ or offence $\$$ or incarcerat $\$$ or crim $\$$ or jail $\$$ or delinq $\$$ or punish $\$$ or convict $\$$ or penitentiar $\$$ or correctional or penal or inmate $\$$ or captive $\$$ ).tw.

6 or/ $1-5$

7 Motivational Interviewing/

8 (interview\$ or feedback\$ or enhancement therap\$).tw.

9 Motivational\$.tw.

108 and 9

117 or 10

12 exp drug abuse/

13 exp addiction/

14 ((drug or substance $\$$ or alcohol or opioid $\$$ or amphetamine $\$$ or cocaine or marijuana or cannabis or phencyclidine or benzodiaz $\$$ ) adj2 (misuse or abuse $\$$ or addict $\$$ or depend $\$)) . t w$.

15 or/12-14

166 and 11 and 15

1711 and 15

\section{Appendix 6. International Bibliography of the Social Sciences}

1951 to November Week 32009

Note: RCT-filter not used

1 exp motivation/

2 motivational*.tw.

3 or $/ 1-2$

4 exp interviews/

5 (interview* ${ }^{*}$ or feedback* or enhancement).tw.

6 or $/ 4-5$

73 and 6

8 exp drug addiction/ or exp drug addicts/

9 exp "drug use"।

10 exp drug users/

11 ((drug or substance* or alcohol or opioid* or amphetamine* or cocaine or marijuana or cannabis or phencyclidine or benzodiaz $\left.{ }^{*}\right)$

$\operatorname{adj} 2$ (misuse or abuse* or addict* or depend $\left.^{*}\right)$ ).tw.

12 exp cannabis/

13 exp drugs/

14 exp alcohol/

Motivational interviewing for substance abuse (Review)

Copyright (? 201 I The Cochrane Collaboration. Published by John Wiley \& Sons, Ltd. 
15 exp alcoholism/

16 addiction/ or addicts/

17 exp "substance use"/

18 (alcoholi* or drinker* or drinking*).tw.

19 or/8-18

$20 \quad 7$ and 19

\section{Appendix 7. ISI Web of Science (Thomson)}

Date: 30.11 .2010

Note: RCT-filter not used

\# 7 \#6 AND \#3

Databases $=$ SCI-EXPANDED, SSCI, A\&HCI Timespan $=$ All Years

\# 6 \#5 AND \#4

Databases $=$ SCI-EXPANDED, SSCI, A\&HCI Timespan $=$ All Years

\# 5 Topic $=\left(\right.$ motivational $\left.{ }^{*}\right)$

Databases=SCI-EXPANDED, SSCI, A\&HCI Timespan=All Years

\# 4 Topic=(interview* ${ }^{*}$ or feedback* or enhancement)

Databases $=$ SCI-EXPANDED, SSCI, A\&HCI Timespan $=$ All Years

\# 3 \#2 OR \#1

Databases $=$ SCI-EXPANDED, SSCI, A\&HCI Timespan $=$ All Years

\# 2 Topic $=\left(\right.$ alcoholi* ${ }^{*}$ or drinker* ${ }^{*}$ or drinking*)

Databases $=$ SCI-EXPANDED, SSCI, A\&HCI Timespan $=$ All Years

\# 1 Topic=((((drug or substance* or alcohol or opioid* or amphetamine* or cocaine or marijuana or cannabis or phencyclidine or benzodiaz $\left.{ }^{*}\right)$ same (misuse or abuse* or addict* or depend*))))

Databases=SCI-EXPANDED, SSCI, A\&HCI Timespan=All Years

\section{Appendix 8. C2-SPECTR}

Date: 23.11.2009

Note: RCT-filter not used

interview or enhancement or feedback AND (motivational or motivation)

\section{Appendix 9. Sociological Abstracts}

CSA Illumina

Date: 30.11 .2010

Note: RCT-filter not used

(((drug or substance* or alcohol or opioid* or amphetamine* or cocaine or marijuana or cannabis or phencyclidine or benzodiaz*) within 2 (misuse or abuse* or addict* or depend*)) or (alcoholi* or drinker* or drinking*) or (DE=("addiction" or "drug addiction" or "drug injection" or "drugs" or "narcotic drugs" or "opiates" or "heroin" or "psychedelic drugs" or "lysergic acid diethylamide" or "tranquilizing drugs")) or (DE=("substance abuse" or "alcohol abuse" or "drug abuse" or "drug addiction")) ) and (((interview* or feedback* or enhancement) or $(\mathrm{DE}=$ "feedback") or $(\mathrm{DE}=$ "interviews")) and $(($ motivational $*)$ or $(\mathrm{DE}=$ "motivation”))) 


\section{Appendix 10. SveMed+}

Date: 30.11 .2010

Note: RCT-filter not used

Search term: motivational

\section{Appendix I I. Bibliograpy of Nordic Criminology}

Date: 23.11.2009

Note: RCT-filter not used

Search term: motivational

\section{Appendix 12. CINCH}

Date: 30.11 .2010

Note: RCT-filter not used

Search term: +motivational

\section{Appendix 13. NCJRS}

Date: 30.11 .2010

Note: RCT-filter not used

Search term:

Subject: motivational (Site search)

\section{Appendix I4. Springerlink}

Date: 02.10 .2010

Note: RCT-filter not used

Search terms:

Summary: motivational and (interview* or feedback* or enhancement*)

\section{Appendix I5. Wiley Interscience}

Date: 02.12.2010

Note: RCT-filter not used

Search terms:

motivational and (interview* or feedback* or enhancement*) in Article Titles

\section{Appendix 16. Drug Data (formerly DrugScope Library)}

Date: 02.12 .2010

Note: RCT-filter not used

Search terms:

Title or Subject: motivational interview* or motivational feedback* or motivational enhancement* 


\section{Appendix 17. Electronic Library of the National Documentation Centre on DRug Use (NCD)}

Date: 02.12 .2010

Note: RCT-filter not used

Search term:

Motivational

\section{Appendix 18. Google}

Date: 02.02.2009

research OR evaluation OR evaluations OR outcome OR outcomes OR effect OR effects OR trial OR trials OR study OR studies "motivational interviewing"

First 100 hits

\section{Appendix 19. Google Scholar}

Date: 02.02.2009

research OR evaluation OR evaluations OR outcome OR outcomes OR effect OR effects OR trial OR trials OR study OR studies "motivational interviewing"

First 100 hits

\section{Appendix 20. Drug Data}

Date 02.12 .2010

\section{H IS T ORY}

Protocol first published: Issue 4, 2009

Review first published: Issue 5, 2011

\begin{tabular}{lll}
\hline Date & Event & Description \\
\hline 13 January 2011 & Amended & First draft of this review. \\
\hline
\end{tabular}

\section{CONTRIBUTIONS OF AUTHORS}

Karlsen conceived of the idea and commissioned the review. All reviewers were involved in planning the review. Smedslund wrote the methods section of the protocol. Karlsen and Smedslund wrote the background. Hammerstrøm developed the search strategy, performed the original searches and the final search in November 2010. All authors were involved with screening of studies. Smedslund and Berg did the risk of bias and data extraction. Berg and Smedslund graded the results. Smedslund did the analyses and wrote the results and discussion. 


\section{DECLARATIONS OF INTEREST}

None.

\section{SOURCES OF SUPPORT}

\section{Internal sources}

- Norwegian Knowledge Centre for the Health Services, Norway.

\section{External sources}

- No sources of support supplied

\section{DIFFERENCES BETWEEN PROTOCOL ANDREVIEW}

We excluded studies that recruited participants in emergency rooms and provided one session of MI during the stay in the emergency room. Some of the searches in electronic databases are not up to date. PsychExtra (search date January 14, 2008) and International Bibliography of the Social Sciences (November 2009) were not searched in November 2010 because we did not have access. C2 SPECTR and Bibliography of Nordic Criminology were searched on November 23, 2009, and these databases have not been updated since this date. Google and Google Scholar were searched on February 2, 2009, and we did not believe that a new search was worthwhile in November 2010.

In cases where effect size information could not be obtained from the authors of the primary studies, we used effect size data from published systematic reviews and meta-analyses. If necessary, we contacted the authors of the systematic reviews/meta-analyses for more information.

We do not report fixed-effect meta-analyses because we believe that there are systematic differences between studies related to differences in interventions given, populations studied, comparison groups, and outcome measures.

We did not do separate analyses for persons with and without mental problems. There was only one study (Martino 2006), in which the participants were explicitly described as having mental problems, but mental problems are so frequently co-occurring with substance abuse that we did not believe it was meaningful to do separate analyses for this variable. 